\title{
Hydrology of Northern Utah Valley, Utah County, Utah, 1975-2005
}

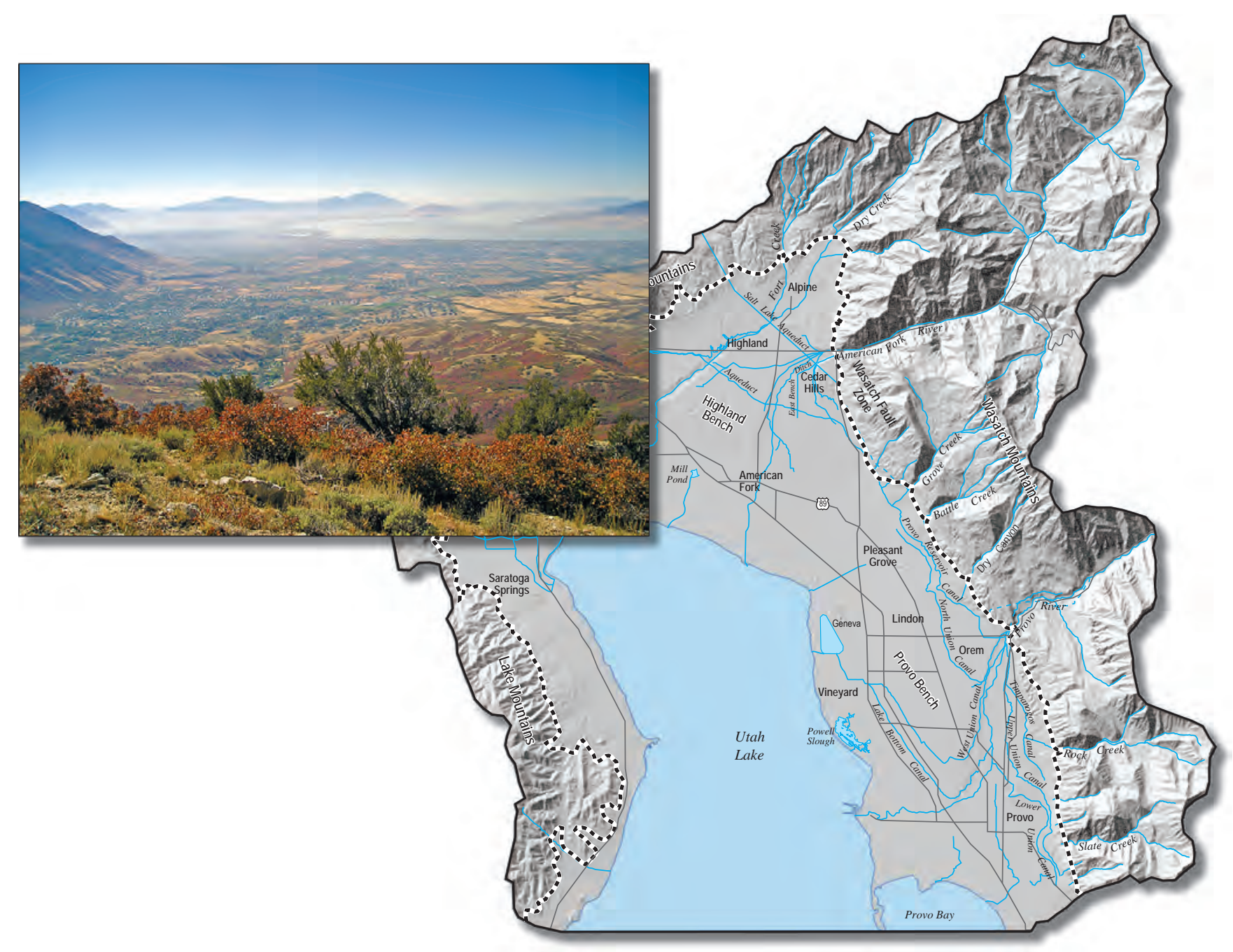

Prepared in cooperation with the

Central Utah Water Conservancy District; Jordan Valley Water Conservancy District representing Draper City; Highland Water Company; Utah Department of Natural Resources, Division of Water Rights; and the municipalities of Alpine, American Fork, Cedar Hills, Eagle Mountain, Highland, Lehi, Lindon, Orem, Pleasant Grove, Provo, Saratoga Springs, and Vineyard

Scientific Investigations Report 2008-5197

Version 2.0, February 2009

U.S. Department of the Interior

U.S. Geological Survey 
Cover photo: View of northern Utah Valley, Utah, looking south from ridgeline above Highland, Utah.

Source: Jay Cederberg, USGS, September 2003. 


\section{Hydrology of Northern Utah Valley, Utah County, Utah, 1975-2005}

By Jay R. Cederberg, Philip M. Gardner, and Susan A. Thiros

Prepared in cooperation with the

Central Utah Water Conservancy District; Jordan Valley Water Conservancy District representing Draper City; Highland Water Company; Utah Department of Natural Resources, Division of Water Rights; and the municipalities of Alpine, American Fork, Cedar Hills, Eagle Mountain, Highland, Lehi, Lindon, Orem, Pleasant Grove, Provo, Saratoga Springs, and Vineyard

Scientific Investigations Report 2008-5197

Version 2.0, February 2009

U.S. Department of the Interior U.S. Geological Survey 


\section{U.S. Department of the Interior \\ Dirk Kempthorne, Secretary}

\section{U.S. Geological Survey \\ Mark D. Myers, Director}

\section{U.S. Geological Survey, Reston, Virginia: 2009}

For additional information write to:

U.S. Geological Survey

Director, USGS Utah Water Science Center

2329 W. Orton Circle

Salt Lake City, UT 84119-2047

Email: GS-W-UTpublic-info@usgs.gov

URL: http://ut.water.usgs.gov/

For more information about the USGS and its products:

Telephone: 1-888-ASK-USGS

World Wide Web: http://www.usgs.gov/

Suggested citation:

Cederberg, J.R., Gardner, P.M., and Thiros, S.A., 2009, Hydrology of Northern Utah Valley, Utah County, Utah, 1975-2005: U.S. Geological Survey Scientific Investigations Report 2008-5197, 114 p.

Any use of trade, firm, or product names is for descriptive purposes only and does not imply endorsement by the U.S. Government.

Although this report is in the public domain, permission must be secured from the individual copyright owners to reproduce any copyrighted materials contained within this report. 


\section{Contents}

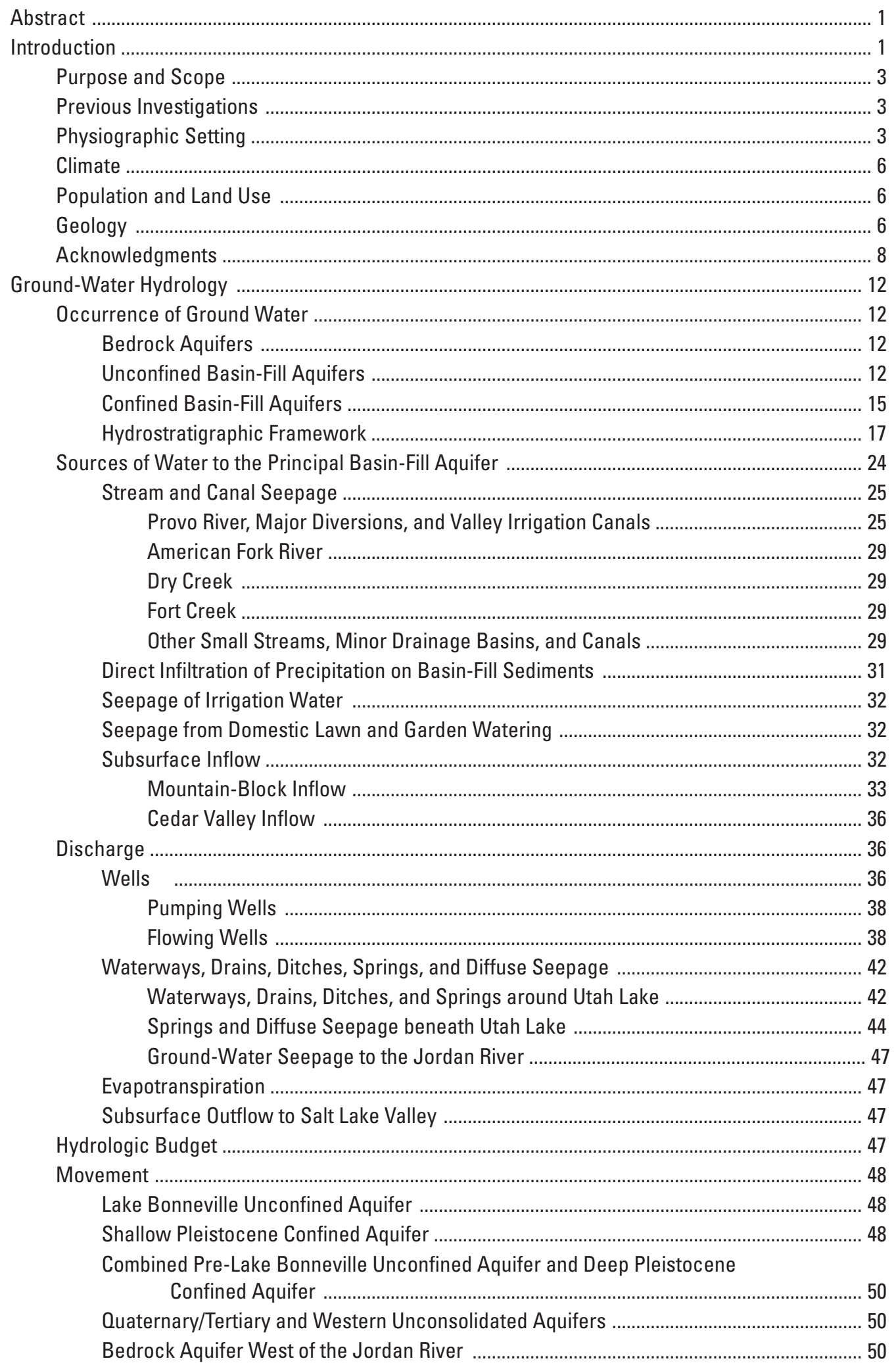




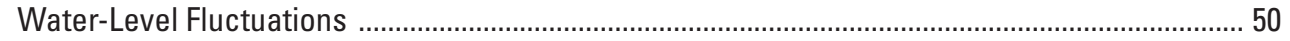

Short-Term Fluctuations ............................................................................................ 54

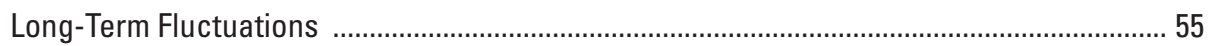

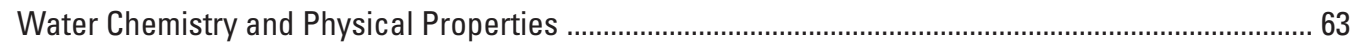

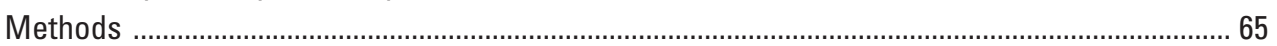

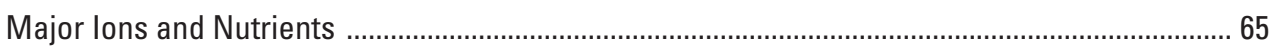

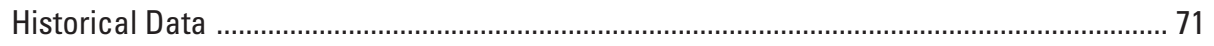

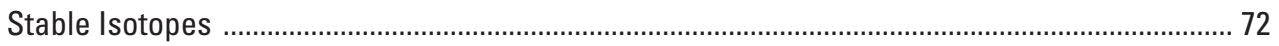

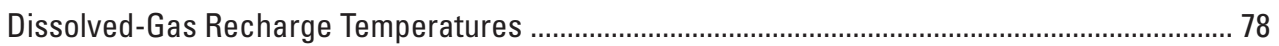

Tritium and Apparent Ground-Water Age ................................................................................... 82

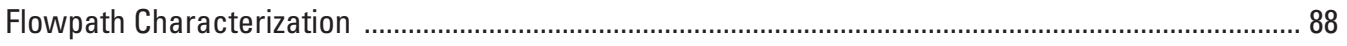

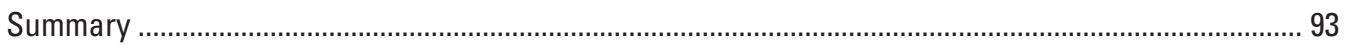

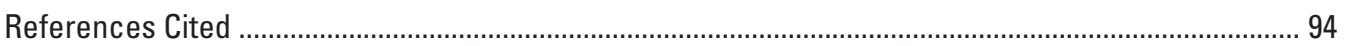

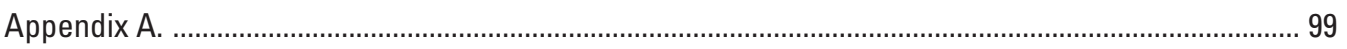

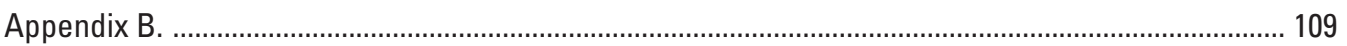

\section{Figures}

1. Map showing location of northern Utah Valley study area, Utah ........................................ 2

2. Map showing location of major physical features, streams, canals, ditches, and faults in northern Utah Valley, Utah

3. Generalized block diagram showing the mountain block, basin-fill deposits, and hydrologic conceptual model in northern Utah Valley, Utah

4. Map showing distribution of mean annual precipitation throughout the northern Utah Valley study area, Utah.

5. Graph showing annual precipitation in the northern Utah Valley study area and the monthly average water-surface altitude of Utah Lake, Utah, 1949-2005

6. Map showing distribution of commercial and residential land-use increase in northern Utah Valley, Utah, 1980-95 and 1995-2002 …………........................................ 9

7. Map showing distribution of land cover in northern Utah Valley, Utah, 2002 ..................... 11

8. Map showing location of wells with lithologic information and cross sections in the northern Utah Valley study area, Utah

9. Cross section and effect of faults on flowpaths in the basin-fill deposits and bedrock in the Cedar Pass area, northern Utah Valley study area, Utah

10. Map showing extent of the basin-fill aquifers and confining units as determined from the hydrostratigraphic framework, northern Utah Valley, Utah ....

11. Three-dimensional representation of wells with lithologic information used for development of a hydrostratigraphic framework, northern Utah Valley, Utah

12. Fence diagram representing the hydrostratigraphic framework of the principal basin-fill aquifer in northern Utah Valley, Utah

13. Cross sections representing the hydrostratigraphic framework along Dry Creek

(B-B') and across the valley floor from the Jordan Narrows to Utah Lake at American Fork (C-C'), northern Utah Valley, Utah .

14. Cross section representing the hydrostratigraphic framework along Battle Creek near Pleasant Grove (D-D'), northern Utah Valley, Utah

15. Cross sections representing the hydrostratigraphic framework from Utah Lake at Provo River to Provo Canyon (E-E') and from Geneva to near Provo Bay (F-F'), northern Utah Valley, Utah

16. Cross section representing the hydrostratigraphic framework along West Canyon Creek from Cedar Pass to Utah Lake at Saratoga Springs (G-G'), northern Utah Valley, Utah 
17. Graph showing average monthly streamflow of the American Fork River above the upper power plant in American Fork Canyon, Utah County, Utah, 1975-2005

18. Graph showing correlation of streamflow for Dry Creek, Fort Creek, and West Canyon Creek to the American Fork River, northern Utah Valley study area, Utah 30

19. Map showing distribution of net infiltration in the mountain block as computed from the adjusted Basin Characterization Model, northern Utah Valley study area, Utah ........ 37

20. Graph showing annual discharge from flowing and pumping wells in northern Utah Valley, Utah, 1975-2004

21. Graph showing relation of measured water level and flowing-well discharge in 2004, as a ratio of 1982 measured values, northern Utah Valley, Utah

22. Graph showing calculated flowing irrigation-well discharge adjusted to reflect the addition of new wells and removal of existing wells within the discharge area of northern Utah Valley, Utah, 1975-2004

23. Map showing location of measured waterways, drains, ditches, and springs around Utah Lake in northern Utah Valley, Utah, 2003-04

24. Graph showing relation of precipitation, discharge from irrigation canals, and discharge from waterways, drains, ditches, and springs around Utah Lake in northern Utah Valley, Utah

25. Map showing location of wells where water levels were measured in March-April 2004 and then seasonally to June 2005 in northern Utah Valley, Utah

26. Potentiometric map for the shallow Pleistocene aquifer in northern Utah Valley, Utah, March-April 2004 51

27. Potentiometric map for the combined pre-Lake Bonneville and deep Pleistocene aquifers in northern Utah Valley, Utah, March-April 2004 52

28. Potentiometric map for the Quaternary/Tertiary and Western unconsolidated aquifers in northern Utah Valley, Utah, March-April 2004

29. Water-level hydrograph at well (D-4-1)36abc-1 near Highland and monthly streamflow in the American Fork River, northern Utah Valley, Utah, November 2003 to September 2005

30. Boxplot showing quarterly water-level changes in wells in northern Utah Valley, Utah, March 2004-June 2005

31. Graph showing quarterly water-level changes in selected wells in northern Utah Valley, Utah, March 2004-June 2005. 56

32. Map showing generalized water-level change in the principal basin-fill aquifer of northern Utah Valley, Utah, 1981-2004 58

33. Long-term hydrographs displaying multi-year trends and fluctuations in wells in northern Utah Valley, Utah, 1936-2005

34. Long-term hydrographs displaying multi-year trends and fluctuations in wells west of the Jordan River in northern Utah Valley, Utah, 1956-2005

35. Map showing location of sampled sites and major-ion composition of ground water in northern Utah Valley, Utah, 2003-04

36. Graph showing major-ion composition of ground water sampled from 34 sites in northern Utah Valley, Utah, 2003-04...

37. Boxplot showing dissolved-solids concentration in water samples collected from the shallow Pleistocene, combined deep Pleistocene and pre-Lake Bonneville, and Quaternary/Tertiary aquifers in northern Utah Valley, Utah, 2003-05.

38. Boxplot showing dissolved nitrate plus nitrite concentration in ground water sampled in northern Utah Valley, Utah, 2003-04

39. Graph showing correlation of specific conductance and dissolved-solids concentration in ground-water samples collected in northern Utah Valley, Utah, 1948-2005

40. Boxplot showing percent difference in specific conductance and dissolvedsolids concentration for water samples collected from 22 wells in northern Utah Valley, Utah, during 1980-82 and 2004-05 
41. Graphs showing stable-isotope ratios from ground- and surface-water samples collected throughout Salt Lake Valley, Utah Valley, and the Wasatch Mountains, Utah, 1981-2004

42. Map showing distribution of maximum recharge temperatures for ground water sampled in northern Utah Valley, Utah, 2003-05

43. Map showing distribution of minimum fraction of mountain-block subsurface inflow for ground water sampled in northern Utah Valley, Utah, 2003-05

44. Graph showing tritium concentration in precipitation and the relation between initial tritium concentration and apparent recharge year for ground water sampled during 2003-05 in northern Utah Valley, Utah

45. Map showing distribution of apparent tritium/helium-3 age and interpreted age category for ground water sampled in northern Utah Valley, Utah, 2003-05

46. Map showing generalized flowpaths originating from mountain-block subsurface inflow and recharge sources along the mountain front in northern Utah Valley, Utah ..... 89

47. Location of sites sampled, direction of ground-water flow, and major-ion composition of water from wells along the Dry Creek flowpath, northern Utah Valley, Utah

48. Location of sites sampled, direction of ground-water flow, and major-ion composition of water from wells along the American Fork flowpath, northern Utah Valley, Utah

49. Location of sites sampled, direction of ground-water flow, and major-ion composition of water from wells along a flowpath in the Orem and Provo area, northern Utah Valley, Utah

\section{Tables}

1. Mean annual temperature and precipitation for selected weather stations in the northern Utah Valley study area, Utah County, Utah, 1971-2000

2. Population statistics and projections for northern Utah Valley, Utah .................................... 10

3. Land-use change data for northern Utah Valley, Utah, 1966-2002 ........................................... 10

4. Sources of water and discharge as it relates to the ground-water hydrologic budget for the principal basin-fill aquifer in northern Utah Valley, Utah, 1975-2004

5. Sources of water to the principal basin-fill aquifer in northern Utah Valley, Utah, 1975-2004

6. Annual gaged or estimated streamflow for streams in northern Utah Valley, Utah, 1975-2004

7. Mean annual flow for trans-basin transfers and major diversions within the Provo River Basin, Utah County, Utah, 1975-2004

8. Average annual flow and seepage loss for streams and major canals in northern Utah Valley, Utah, 1975-2004

9. Ratio of drainage-basin area and annual precipitation in ungaged basins relative to the gaged American Fork River basin, northern Utah Valley, Utah

10. Hydrologic budget for the mountain uplands (only) within each hydrologic unit in the northern Utah Valley study area, 1971-2000.

11. Consumptive-use estimates for vegetation and land cover throughout the mountain block of the northern Utah Valley study area, Utah, 2002

12. Net infiltration to the mountain block and mountain-block subsurface inflow to the basin-fill aquifer in the northern Utah Valley study area, Utah, 1971-2000 
13. Discharge components of the hydrologic budget for the principal basin-fill aquifer in northern Utah Valley, Utah, 1975-2004

14. Annual well discharge from the principal basin-fill aquifer in northern Utah Valley, Utah, 1975-2004

15. Well characteristics, water level, and discharge from flowing wells in northern Utah Valley, Utah, 1982-2003-04

16. Measured water levels, water levels relative to 1982 levels, and calculated flowing irrigation-well discharge in northern Utah Valley, Utah, 1975-2004

17. Discharge from waterways, drains, ditches, and springs around Utah Lake in northern Utah Valley, Utah, 2003-04

18. Summary of water-level changes in wells measured during 1981 and 2004 in northern Utah Valley, Utah......

19. Physical characteristics of 36 wells and springs sampled in northern Utah Valley, Utah, 2003-05

20. Physical properties and concentration of dissolved ions and nutrients in sampled ground water, northern Utah Valley, Utah, 2003-05

21. Specific conductance and dissolved-solids concentration of water from wells sampled in northern Utah Valley, Utah, 1980-82 and 2004-05

22. Stable-isotope, dissolved-gas, and recharge-temperature data for ground water sampled in northern Utah Valley, Utah, 2003-05

23. Tritium/helium-3 age data for ground water sampled in northern Utah Valley, Utah, 2003-05

24. Estimates of volumetric recharge rate to sections of northern Utah Valley, Utah, based on tritium/helium-3 age data

Appendix A. Physical characteristics and water-level measurements in wells in northern Utah Valley, Utah, March-April 2004 and from previous studies 100

Appendix B. Quarterly water-level measurements in wells in northern Utah Valley, Utah, March 2004-June 2005 


\section{Conversion Factors and Datums}

\begin{tabular}{|c|c|c|}
\hline Multiply & By & To obtain \\
\hline \multicolumn{3}{|c|}{ Length } \\
\hline inch (in.) & 2.54 & centimeter $(\mathrm{cm})$ \\
\hline foot (ft) & 0.3048 & meter (m) \\
\hline mile (mi) & 1.609 & kilometer (km) \\
\hline \multicolumn{3}{|c|}{ Area } \\
\hline acre & 0.004047 & square kilometer $\left(\mathrm{km}^{2}\right)$ \\
\hline square mile $\left(\mathrm{mi}^{2}\right)$ & 2.590 & square kilometer $\left(\mathrm{km}^{2}\right)$ \\
\hline \multicolumn{3}{|c|}{ Volume } \\
\hline acre-foot (acre-ft) & 1,233 & cubic meter $\left(\mathrm{m}^{3}\right)$ \\
\hline \multicolumn{3}{|c|}{ Flow rate } \\
\hline inches per year (in/yr) & 25.4 & millimeters per year (mm/yr) \\
\hline acre-foot per year (acre-ft/yr) & 1,233 & cubic meter per year $\left(\mathrm{m}^{3} / \mathrm{yr}\right)$ \\
\hline cubic foot per second $\left(\mathrm{ft}^{3} / \mathrm{s}\right)$ & 0.02832 & cubic meter per second $\left(\mathrm{m}^{3} / \mathrm{s}\right)$ \\
\hline \multicolumn{3}{|c|}{ Hydraulic conductivity } \\
\hline foot per day (ft/d) & 0.3048 & meter per day $(\mathrm{m} / \mathrm{d})$ \\
\hline foot per year (ft/yr) & 0.3048 & meter per year (m/yr) \\
\hline \multicolumn{3}{|c|}{ Gradient } \\
\hline foot per mile ( $\mathrm{ft} / \mathrm{mi}$ ) & 0.1894 & meter per kilometer $(\mathrm{m} / \mathrm{km})$ \\
\hline \multicolumn{3}{|c|}{ Transmissivity* } \\
\hline foot squared per day $\left(\mathrm{ft}^{2} / \mathrm{d}\right)$ & 0.09290 & meter squared per day (m²/d) \\
\hline
\end{tabular}

Temperature in degrees Celsius $\left({ }^{\circ} \mathrm{C}\right)$ may be converted to degrees Fahrenheit $\left({ }^{\circ} \mathrm{F}\right)$ as follows:

$$
{ }^{\circ} \mathrm{F}=\left(1.8 \times^{\circ} \mathrm{C}\right)+32
$$

Temperature in degrees Fahrenheit $\left({ }^{\circ} \mathrm{F}\right)$ may be converted to degrees Celsius $\left({ }^{\circ} \mathrm{C}\right)$ as follows:

$$
{ }^{\circ} \mathrm{C}=\left({ }^{\circ} \mathrm{F}-32\right) / 1.8 .
$$

Vertical coordinate information is referenced to the National Geodetic Vertical Datum of 1929 (NGVD 29). Altitude, as used in this report, refers to distance above the vertical datum. Horizontal coordinate information is referenced to the North American Datum of 1983 (NAD 83).

Specific conductance is reported in microsiemens per centimeter at 25 degrees Celsius $\left(\mu \mathrm{S} / \mathrm{cm}\right.$ at $\left.25^{\circ} \mathrm{C}\right)$.

Concentrations of chemical constituents in water are reported either in milligrams per liter $(\mathrm{mg} / \mathrm{L})$, or micrograms per liter $(\mu \mathrm{g} / \mathrm{L})$.

Concentrations of dissolved gases are reported in cubic centimeters of gas at standard temperature and pressure per gram of water (ccSTP/g).

Tritium concentration is reported in tritium units (TU). 
The system of numbering wells, springs, and other hydrologic-data sites in Utah is based on the cadastral land-survey system of the U.S. Government. The number, in addition to designating the site, describes its position in the land net. By the land-survey system, the State is divided into four quadrants by the Salt Lake Base Line and the Salt Lake Meridian. These quadrants are designated by the uppercase letters A, B, C, and D, indicating the northeast, northwest, southwest, and southeast quadrants, respectively. Numbers designating the township and range, in that order, follow the quadrant letter, and all three are enclosed in parentheses. The number after the parentheses indicates the section and is followed by three letters indicating the quarter section, the quarter-quarter section, and the quarter-quarter-quarter section - generally 10 acres for regular sections ${ }^{1}$. The lowercase letters a, b, c, and d indicate, respectively, the northeast, northwest, southwest, and southeast quarters of each subdivision. The number after the letters is the serial number of the site within the 10 -acre tract. The letter $\mathrm{S}$ preceding the serial number designates a spring. Thus, (C-5-1)25cdc-1 designates the first well constructed or visited in the southwest $1 / 4$ of the southeast $1 / 4$ of the southwest $1 / 4$ of section 25 , T. 5 S., R. 1 W. The numbering system is illustrated below.

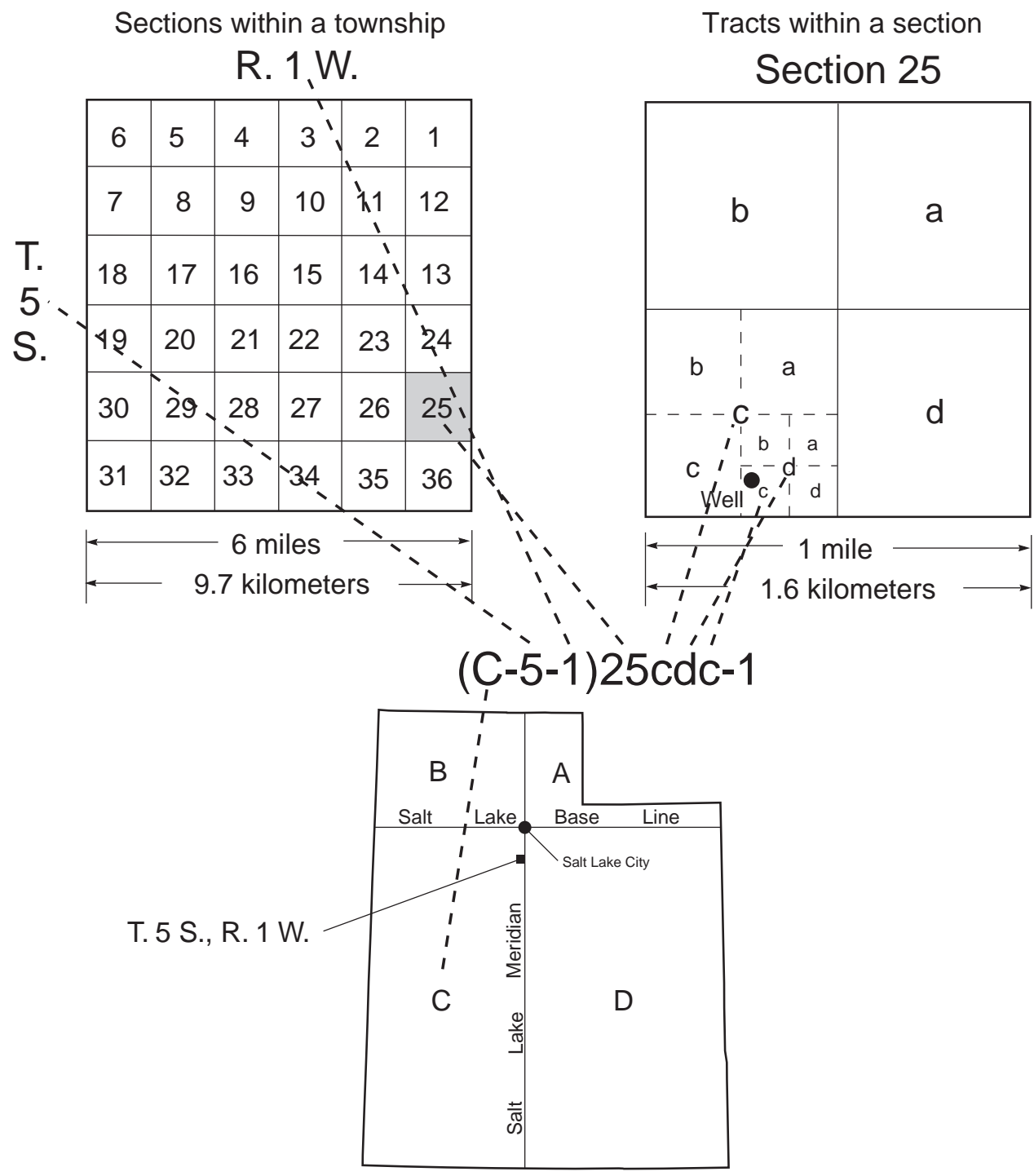

${ }^{1}$ Although the basic land unit, the section, is theoretically 1 square mile, many sections are irregular. Such sections are subdivided into 10-acre tracts, generally beginning at the southeast corner, and the surplus or shortage is taken up in the tracts along the north and west sides of the section. 


\title{
Hydrology of Northern Utah Valley, Utah County, Utah, 1975-2005
}

\author{
By Jay R. Cederberg, Philip M. Gardner, and Susan A. Thiros
}

\section{Abstract}

The ground-water resources of northern Utah Valley, Utah, were assessed during 2003-05 to describe and quantify components of the hydrologic system, determine a hydrologic budget for the basin-fill aquifer, and evaluate changes to the system relative to previous studies. Northern Utah Valley is a horst and graben structure with ground water occurring in both the mountain-block uplands surrounding the valley and in the unconsolidated basin-fill sediments. The principal aquifer in northern Utah Valley occurs in the unconsolidated basin-fill deposits where a deeper unconfined aquifer occurs near the mountain front and laterally grades into multiple confined aquifers near the center of the valley.

Sources of water to the basin-fill aquifers occur predominantly as either infiltration of streamflow at or near the interface of the mountain front and valley or as subsurface inflow from the adjacent mountain blocks. Sources of water to the basin-fill aquifers were estimated to average 153,000 (+/31,500) acre-feet annually during 1975-2004 with subsurface inflow and infiltration of streamflow being the predominant sources. Discharge from the basin-fill aquifers occurs in the valley lowlands as flow to waterways, drains, ditches, springs, as diffuse seepage, and as discharge from flowing and pumping wells. Ground-water discharge from the basin-fill aquifers during 1975-2004 was estimated to average 166,700 (+/$25,900)$ acre-feet/year where discharge to wells for consumptive use and discharge to waterways, drains, ditches, and springs were the principal sources.

Measured water levels in wells in northern Utah Valley declined an average of 22 feet from 1981 to 2004. Water-level declines are consistent with a severe regional drought beginning in 1999 and continuing through 2004.

Water samples were collected from 36 wells and springs throughout the study area along expected flowpaths. Water samples collected from 34 wells were analyzed for dissolved major ions, nutrients, and stable isotopes of hydrogen and oxygen. Water samples from all 36 wells were analyzed for dissolved-gas concentration including noble gases and tritium/ helium-3. Within the basin fill, dissolved-solids concentration generally increases with distance along flowpaths from recharge areas, and shallower flowpaths tend to have higher concentrations than deeper flowpaths. Nitrate concentrations generally are at or below natural background levels. Dissolved-gas recharge temperature data support the conceptual model of the basin-fill aquifers and highlight complexities of recharge patterns in different parts of the valley. Dissolved-gas data indicate that the highest elevation recharge sources for the basin-fill aquifer are subsurface inflow derived from recharge in the adjacent mountain block between the mouths of American Fork and Provo Canyons. Apparent ground-water ages in the basin-fill aquifer, as calculated using tritium/helium-3 data, range from 2 to more than 50 years. The youngest waters in the valley occur near the mountain fronts with apparent ages generally increasing near the valley lowlands and discharge area around Utah Lake.

Flowpaths are controlled by aquifer properties and the location of the predominant recharge sources, including subsurface inflow and recharge along the mountain front. Subsurface inflow is distributed over a larger area across the interface of the subsurface mountain block and basin-fill deposits. Subsurface inflow occurs at a depth deeper than that at which mountain-front recharge occurs. Recharge along the mountain front is often localized and focused over areas where streams and creeks enter the valley, and recharge is enhanced by the associated irrigation canals.

\section{Introduction}

Northern Utah Valley is located on the west side of the Wasatch Mountains in north-central Utah, approximately 30 mi south of Salt Lake City (fig. 1). The valley is experiencing a period of rapid population growth and an associated change from agricultural to commercial and residential land uses. Much of the recent growth is occurring on the west side of the valley, west of the Jordan River and Utah Lake, in a previously undeveloped area. Ground water is the primary source of municipal water within northern Utah Valley, and the increased growth coupled with recent drought conditions has increased municipal supply demand on ground-water resources. Water levels generally declined in northern Utah Valley from March 1975 to March 2005, probably the result of increased withdrawals for public supply (Burden and others, 2005, p. 43). Stresses on the basin-fill aquifers resulting from 


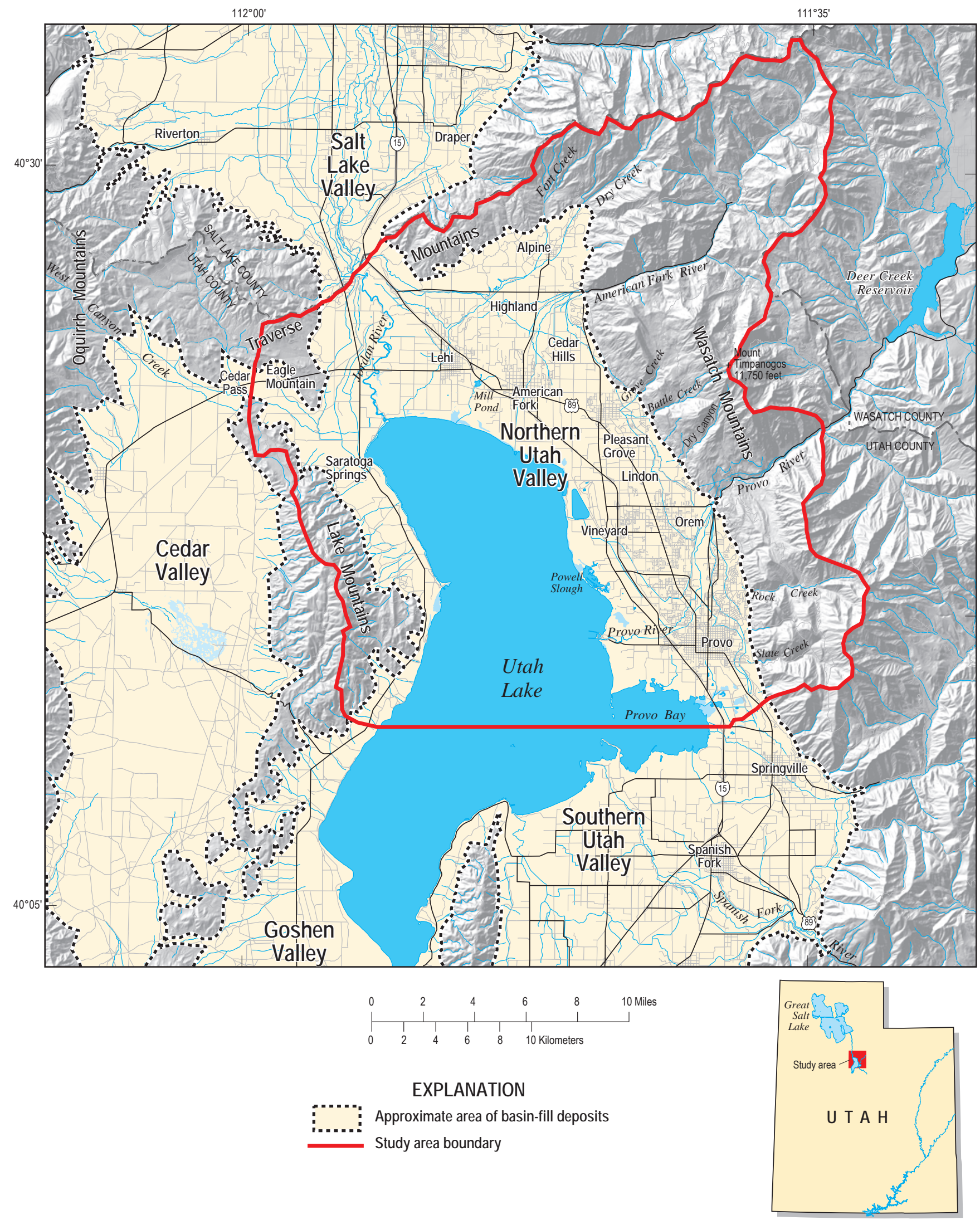

Figure 1. Location of northern Utah Valley study area, Utah. 
increased withdrawals, drought, or both, need to be evaluated in order for water managers to determine maximum amounts of withdrawal that would not adversely affect spring and well discharge, water quality, or other water rights.

In 2003, the U.S. Geological Survey (USGS) began a study of ground-water resources in northern Utah Valley, Utah, in cooperation with the Central Utah Water Conservancy District; Jordan Valley Water Conservancy District representing Draper City; Highland Water Company; Utah Department of Natural Resources, Division of Water Rights; and the municipalities of Alpine, American Fork, Cedar Hills, Eagle Mountain, Highland, Lehi, Lindon, Orem, Pleasant Grove, Provo, Saratoga Springs, and Vineyard. The objectives of this study were to develop a better understanding of the ground-water system, estimate recent and long-term hydrologic budgets, and provide information to help determine potential effects of withdrawals on water levels, water quality, and natural ground-water discharge in northern Utah Valley. The latest conceptual model of the ground-water system in northern Utah Valley, as described by Clark and Appel (1985), was areally expanded and updated to include recently developed areas. In conjunction with this report, the most recent numerical model developed for the study area by Clark (1984) is being updated as well.

\section{Purpose and Scope}

The purpose of this report is to describe the ground-water hydrology of northern Utah Valley, Utah. Emphasis is placed on the occurrence of ground water within the basin-fill valley and the major processes affecting the ground-water hydrologic budget including recharge, discharge, and movement of water. The major components of recharge and discharge are compared in a hydrologic budget for two time periods, 2003 to 2005 and 1975 to 2004, to represent ground-water conditions during data collection specifically for this report (2003-05) and a 30-year average (1975-2004) based on historical data published by Clark and Appel (1985) and annual hydrologic data collected by local, state, and federal agencies. Waterlevel fluctuations, ground-water quality, and characterization of flowpaths also are described and evaluated. Surface water is described only as a source of water and how it relates to ground-water recharge.

The report summarizes and utilizes precipitation, streamflow, ground-water pumping, ground-water levels, spring and agricultural drain discharge, and ground-water chemical data collected from 2003 through 2005. Measured and estimated data for 2003-04 are compared to historical data, where available.

\section{Previous Investigations}

Numerous ground-water resource investigations have been completed in northern Utah Valley. Richardson (1906) was the first to publish data on ground-water occurrence and availability in the area. Hunt and others (1953) studied and described, in detail, the geology of the basin-fill deposits and the associated aquifers. Cordova and Subitzky (1965) updated the work of Hunt and others (1953) and documented yearly ground-water resources for northern Utah Valley during 1948-63. Clark and Appel (1985) refined the conceptual model of northern Utah Valley based on data collected during 1981-82 (Appel and others, 1982), a period of above normal precipitation. Clark (1984) developed the first documented numerical model of the basin-fill aquifers in the area. Brooks and Stolp (1995) evaluated and developed a model for the basin-fill aquifers of southern Utah Valley and Goshen Valley. Feltis (1967) evaluated the ground-water resources of nearby Cedar Valley.

\section{Physiographic Setting}

The 428- $\mathrm{mi}^{2}$ study area consists of the northern half of Utah Valley and the contributing mountain watersheds in north-central Utah (fig. 1). Northern Utah Valley is bounded on the east by the Wasatch Mountains at the eastern edge of the Basin and Range physiographic province (Fenneman, 1931). The Traverse Mountains and the Lake Mountains bound the study area on the north and west, respectively. The southern boundary is delineated by an east-west line bisecting Provo Bay and Utah Lake and is similar to boundaries used by Hunt and others (1953) and Clark and Appel (1985) in northern Utah Valley and Brooks and Stolp (1995) in southern Utah Valley. The boundary is parallel to the direction of ground-water flow, and only a small amount of surface-water flow crosses it.

Land-surface altitude in the study area ranges from about 4,489 $\mathrm{ft}$ around Utah Lake to 11,750 ft at the peak of Mount Timpanogos in the Wasatch Mountains (fig. 2). Maximum altitude in the Traverse Mountains is about 6,680 ft and about $7,690 \mathrm{ft}$ in the Lake Mountains. A distinct break in slope is evident in much of the study area at an altitude of about 5,200 $\mathrm{ft}$ where the valley floor abuts the mountain blocks. The valley floor slopes from the mountains to Utah Lake with an average gradient of less than $50 \mathrm{ft} / \mathrm{mi}$ whereas the gradient in the mountain blocks averages $300 \mathrm{ft} / \mathrm{mi}$ (Clark and Appel, 1985) (fig. 3).

Near the center of the valley is Utah Lake, a large (about $150 \mathrm{mi}^{2}$ ), shallow (9.5 ft average depth) natural freshwater lake that lies in the valley lowlands and overlies approximately 69 $\mathrm{mi}^{2}$ of the $240 \mathrm{mi}^{2}$ of unconsolidated basin-fill deposits in the northern Utah Valley study area. Utah Lake is the natural sink for all of the perennial streams and rivers entering into Utah Valley and for discharge of local and regional aquifers. The lake is managed as an irrigation water source for water users in northern Utah Valley and Salt Lake Valley. The water level in Utah Lake cannot exceed the compromise level of 4,489.045 $\mathrm{ft}$ (approximate level of Utah Lake shown in fig. 2). This level was established as a compromise between downstream water users and property owners surrounding the lake to allow for 


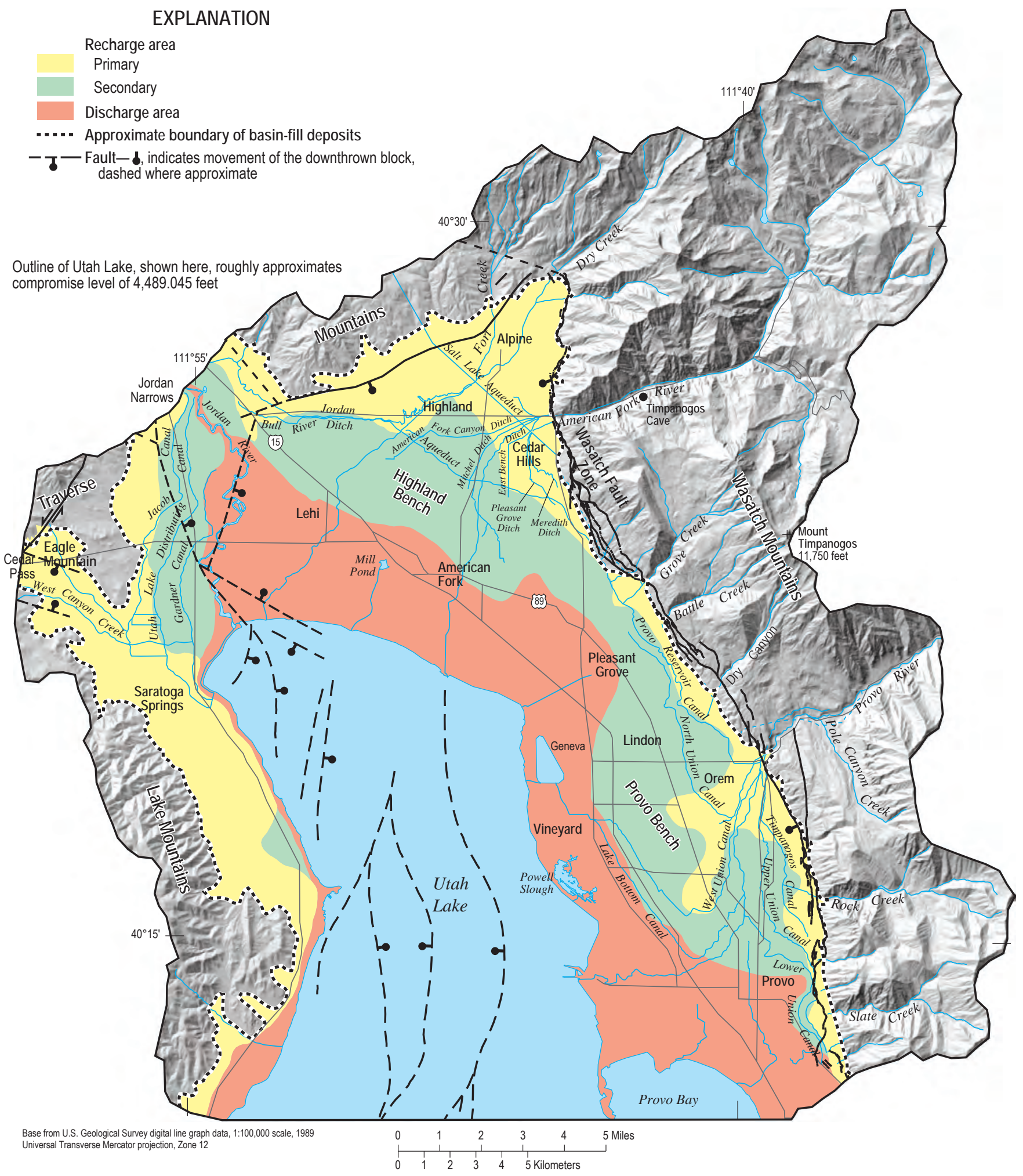

Figure 2. Location of major physical features, streams, canals, ditches, and faults in northern Utah Valley, Utah. 

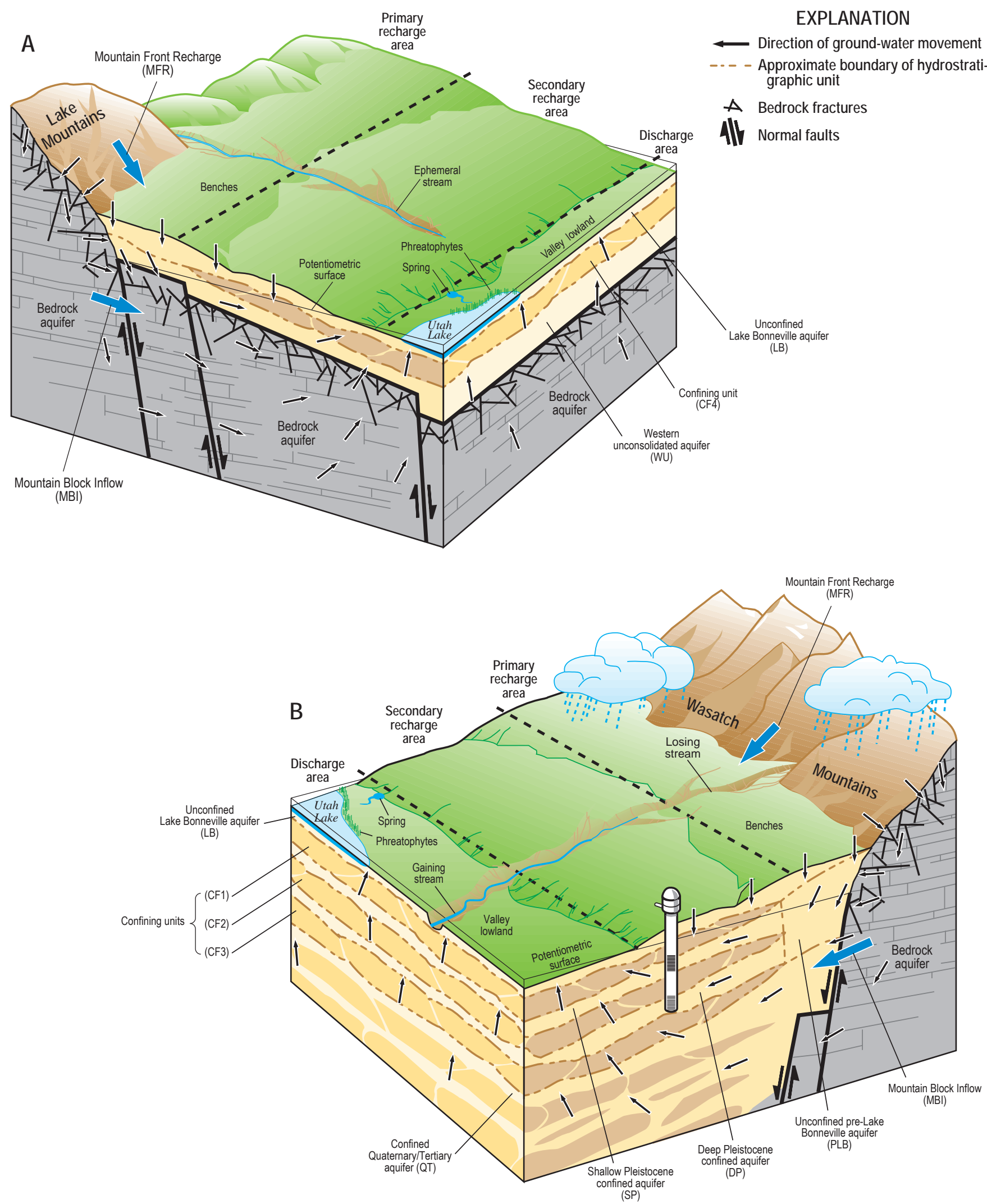

Figure 3. Generalized block diagram showing the mountain block, basin-fill deposits, and hydrologic conceptual model in northern Utah Valley, Utah. 
adequate storage (870,000 acre-ft at compromise) in Utah Lake while preventing flooding of the adjacent lands. Above this level, water must be allowed to flow freely out of Utah Lake to the Jordan River. The Jordan River, which is the natural outlet for Utah Lake, originates at the northwestern end of the lake, flows north through northern Utah Valley, and enters into Salt Lake Valley through the Jordan Narrows (fig. 2).

\section{Climate}

The climate of northern Utah Valley is semi-arid and temperate with a frost-free season from May through September. Mean annual precipitation in the valley from 1971 to 2000 ranged from $12.4 \mathrm{in}$. at the northwestern end of Utah Lake near Lehi, Utah, to 20.1 in. at Brigham Young University at Provo, Utah (National Oceanic and Atmospheric Administration, 2006) (table 1). Mean annual precipitation at a low-altitude mountain weather station, Timpanogos Cave, Utah, was 25.5 in. High-altitude areas of the Wasatch Mountains receive as much as 61 in. of precipitation annually, as determined from Parameter-elevation Regressions on Independent Slopes model data (PRISM) (Daly and others, 1994), with most occurring as snowfall during the winter months (fig. 4). The highest altitudes in the Lake and Traverse Mountains receive less than 23 in. of precipitation annually. The 30-yr (1971-2000) average annual precipitation for the study area was 325,000 acre-ft, with 280,000 acre-ft occurring over the mountains and 45,000 acre-ft in the valley, as determined from PRISM data. Annual precipitation in the study area and the monthly average watersurface altitude of Utah Lake from 1949-2003 are shown in figure 5 .

\section{Population and Land Use}

The population in northern Utah Valley and incorporated areas was approximately 284,000 in 2000 . Northern Utah Valley is part of one of the fastest growing metropolitan areas in the nation (Utah Valley Economic Development Associa- tion, 2002). Population data and statistics are listed in table 2 . The population increased by 71 percent $(117,567)$ during 1980-2000. Sixty-seven percent $(78,737)$ of the 1980-2000 increase occurred during 1990-2000. Population projections for northern Utah Valley indicate that the area will continue to grow, but possibly at a slightly slower rate, to a population of about 470,000 by the year 2030 .

Occurring in conjunction with increasing population is a change in land use resulting from urbanization of agricultural and undeveloped lands (fig. 6). Land use classified as commercial and residential during 1980-2002 increased by 134 percent $(22,300$ to 52,200 acres, table 3$)$, whereas irrigated agricultural lands decreased by about 48 percent $(42,100$ to 21,900 acres). Land-use change is calculated by comparison of land-use surveys conducted in 1980 (Clark and Appel, 1985), 1988, 1995, and 2002 (Utah Department of Natural Resources, 2004). Land use was categorized as (1) irrigated agricultural land, (2) nonirrigated agricultural land including native vegetation, dry land farming, and riparian areas; and (3) commercial and residential lands (fig. 7).

Clark and Appel (1985, p. 9) reported a 10,000-acre increase in land classified as commercial and residential between 1966 and 1980, with about 60 percent of the increase occurring as the conversion of irrigated agricultural land. During 1980-2002, about 68 percent of the new commercial and residential land was converted from irrigated agricultural land. On average during this time period, irrigated and nonirrigated agricultural lands decreased by about 900 and 400 acres per year, respectively, whereas commercial and residential lands increased annually by about 1,300 acres.

\section{Geology}

Utah Valley is a north-south trending, normally faulted horst and graben structure formed during the Tertiary and Quaternary Periods (Clark and Appel, 1985, p. 5). The prominent Wasatch Fault zone forms the eastern boundary between the Wasatch Mountains (eastern bedrock horst) and the sediment-

Table 1. Mean annual temperature and precipitation for selected weather stations in the northern Utah Valley study area, Utah County, Utah, 1971-2000.

[Source: National Oceanic and Atmospheric Administration, 2006]

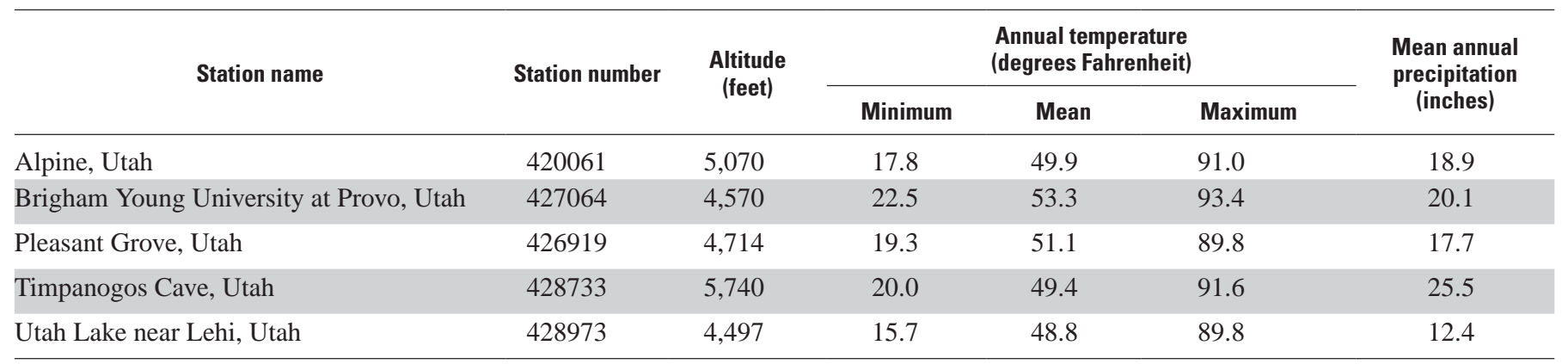




\section{EXPLANATION}

Precipitation, in inches

11 to less than 15

15 to less than 19

19 to less than 23

23 to less than 27

27 to less than 31

31 to less than 35

35 to less than 39

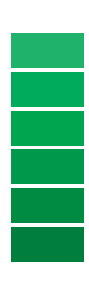

39 to less than 43

43 to less than 47

47 to less than 51

51 to less than 55

55 to less than 59

59 to 61

\section{..... Approximate boundary of basin-fill deposits \\ - Weather station}

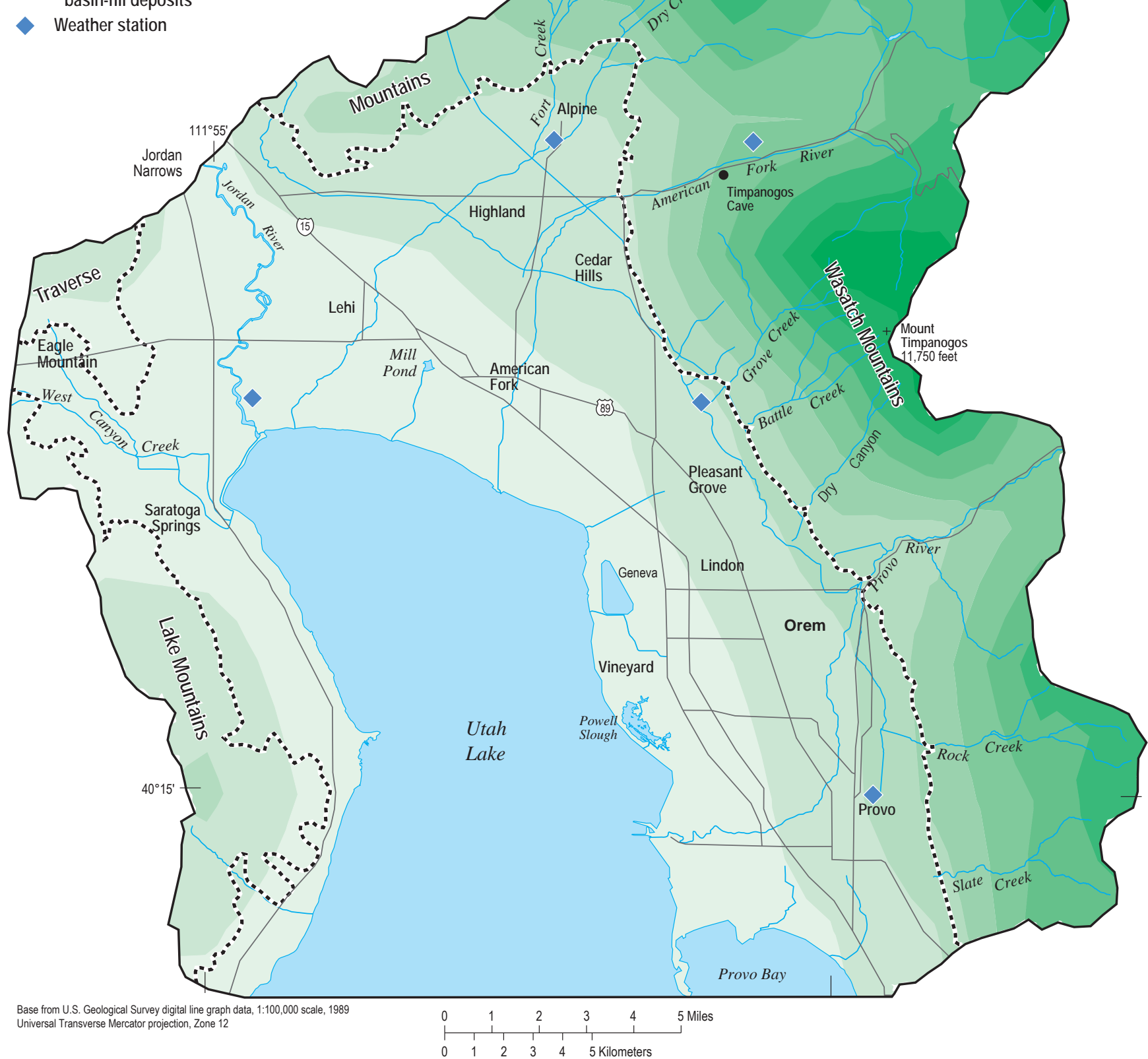

Figure 4. Distribution of mean annual precipitation throughout the northern Utah Valley study area, Utah. 


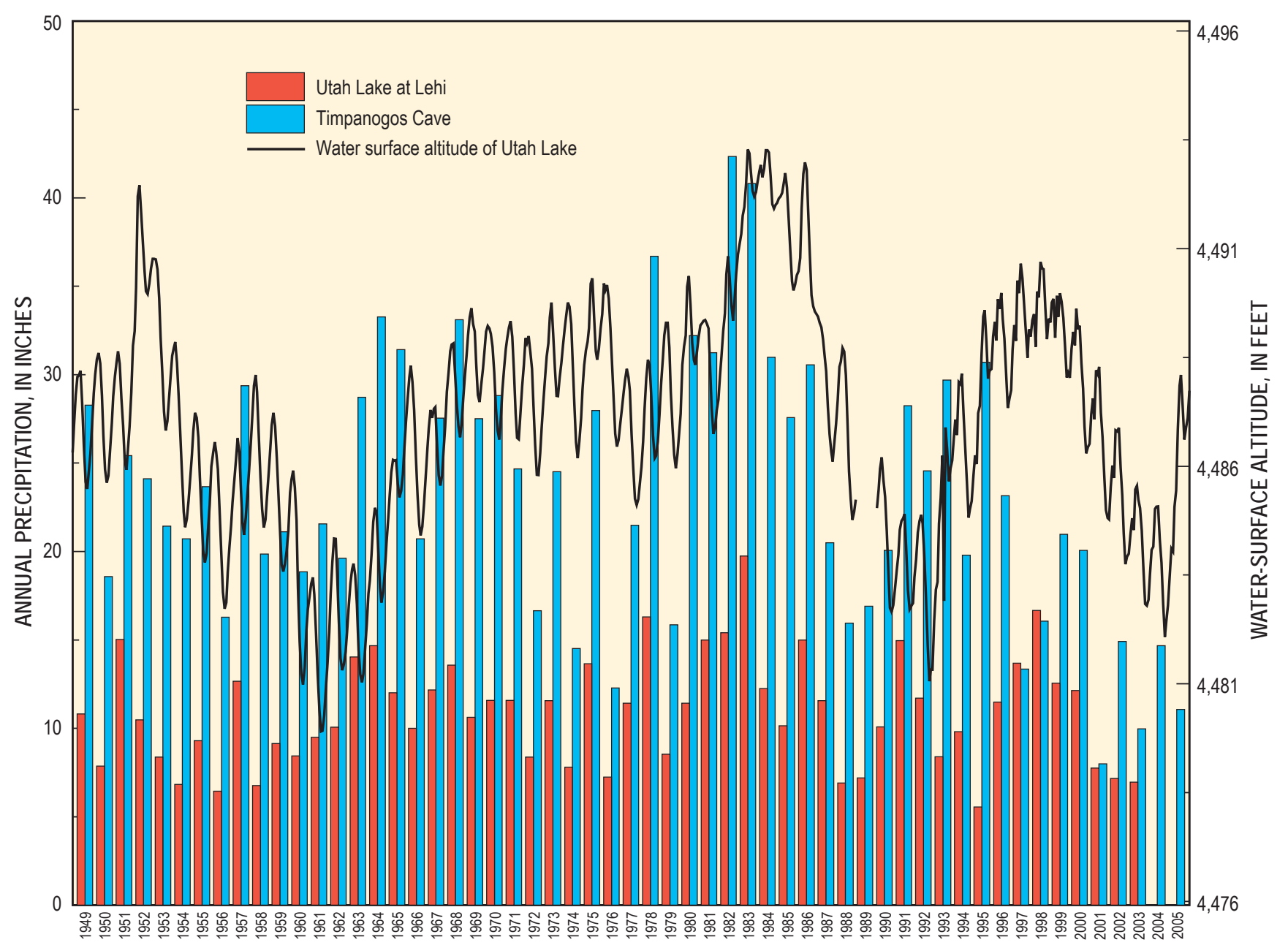

Figure 5. Annual precipitation in the northern Utah Valley study area and the monthly average water-surface altitude of Utah Lake, Utah, 1949-2005.

filled basin of the valley floor (graben) (fig. 3). Displacement along the Utah Valley section of the Wasatch Fault zone occurs along a narrow band and has been reported to be about 7,000 ft or more (Hunt and others, 1953). The Utah Fault zone bounds the west side of the horst and graben system with a series of relatively low-displacement faults adjacent to the Traverse and Lake Mountains (western bedrock horst). These occur over a wider zone with less initial displacement than the Wasatch Fault zone (fig. 2). Gravity surveys have been interpreted to show a sequence of blocks dropping normally from the western mountain block to the center of the valley (Zoback, 1983).

The bedrock forming the mountain blocks (horsts) that flank the east, north, and west sides of northern Utah Valley are predominantly limestones, orthoquartzites, dolomites, and shales of Mississippian and Pennsylvanian age (Hunt and others, 1953; Machette, 1992; Beik, 2003). The northeastern section of mountain block, within the Wasatch Mountains, is composed of altered monzogranites and granodiorites of the Tertiary Little Cottonwood Stock. Tertiary volcanic rocks cap portions of the Traverse Mountains (Beik, 2003).
Sediment derived from the surrounding mountain blocks is the source material filling the basin (graben) and forming the valley floor. The Quaternary-age unconsolidated basinfill deposits were deposited by colluvial, alluvial, fluvial, and lacustrine processes. The coarsest unconsolidated deposits are thickest near the mountain blocks and canyon mouths, whereas fine-grained deposits are thickest near the valley center or below Utah Lake. Intermittently throughout the Quaternary Period, large regionally extensive lakes, including Lake Bonneville, filled the Utah Valley basin (Hunt and others, 1953). The intermittent nature of the large lakes allowed for alternating periods of fine-grained (lacustrine) material deposition when the lakes were present and coarse-grained material deposition during dry periods.

\section{Acknowledgments}

The authors would like to extend their gratitude to the many private land owners and water suppliers who granted access to their property, facilities, wells, and data archives. 


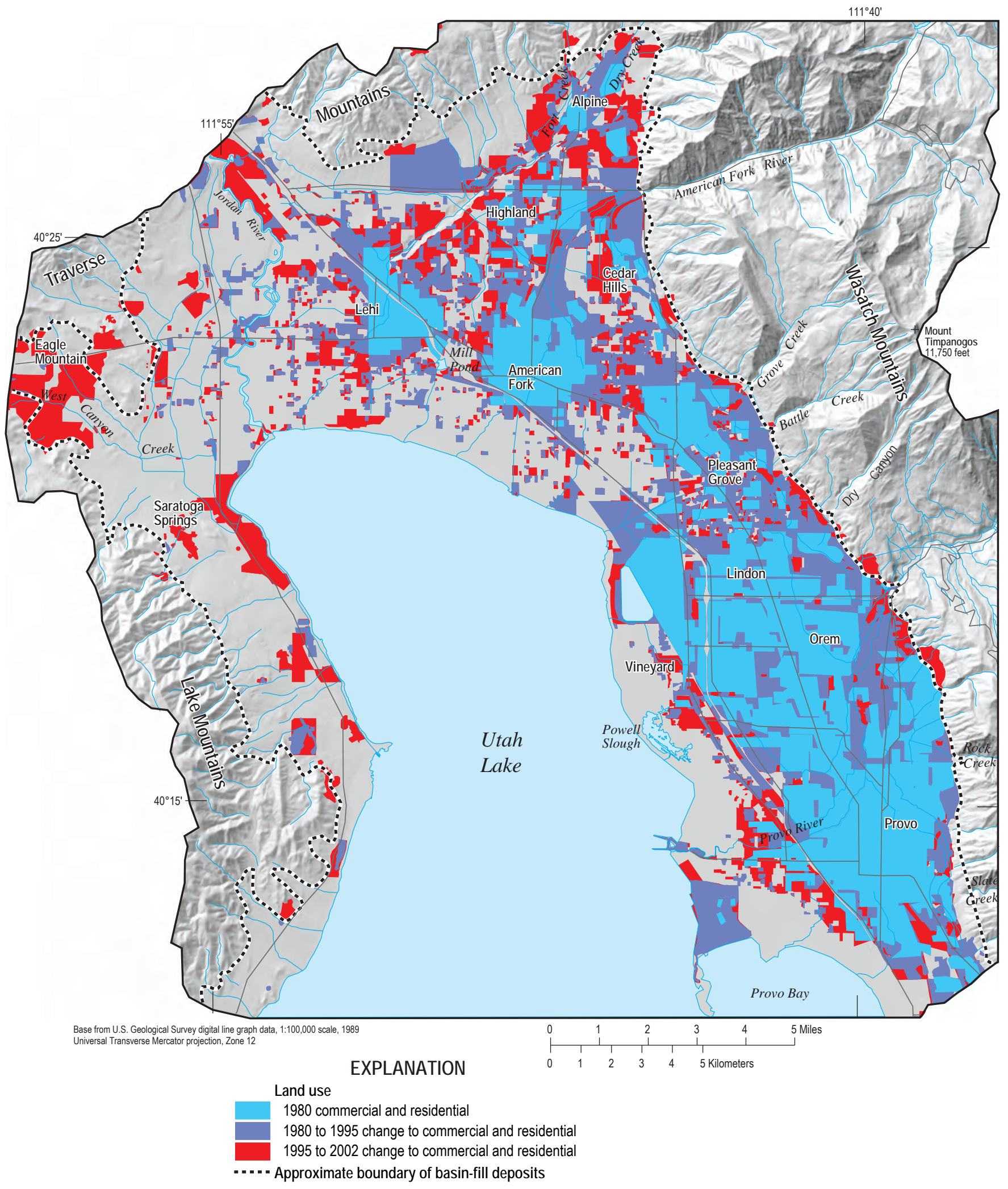

Figure 6. Distribution of commercial and residential land-use increase in northern Utah Valley, Utah, 1980-95 and 1995-2002. 
Table 2. Population statistics and projections for northern Utah Valley, Utah.

[Population statistics for 2010, 2020, and 2030 are projected. A bbreviation: —, no data]

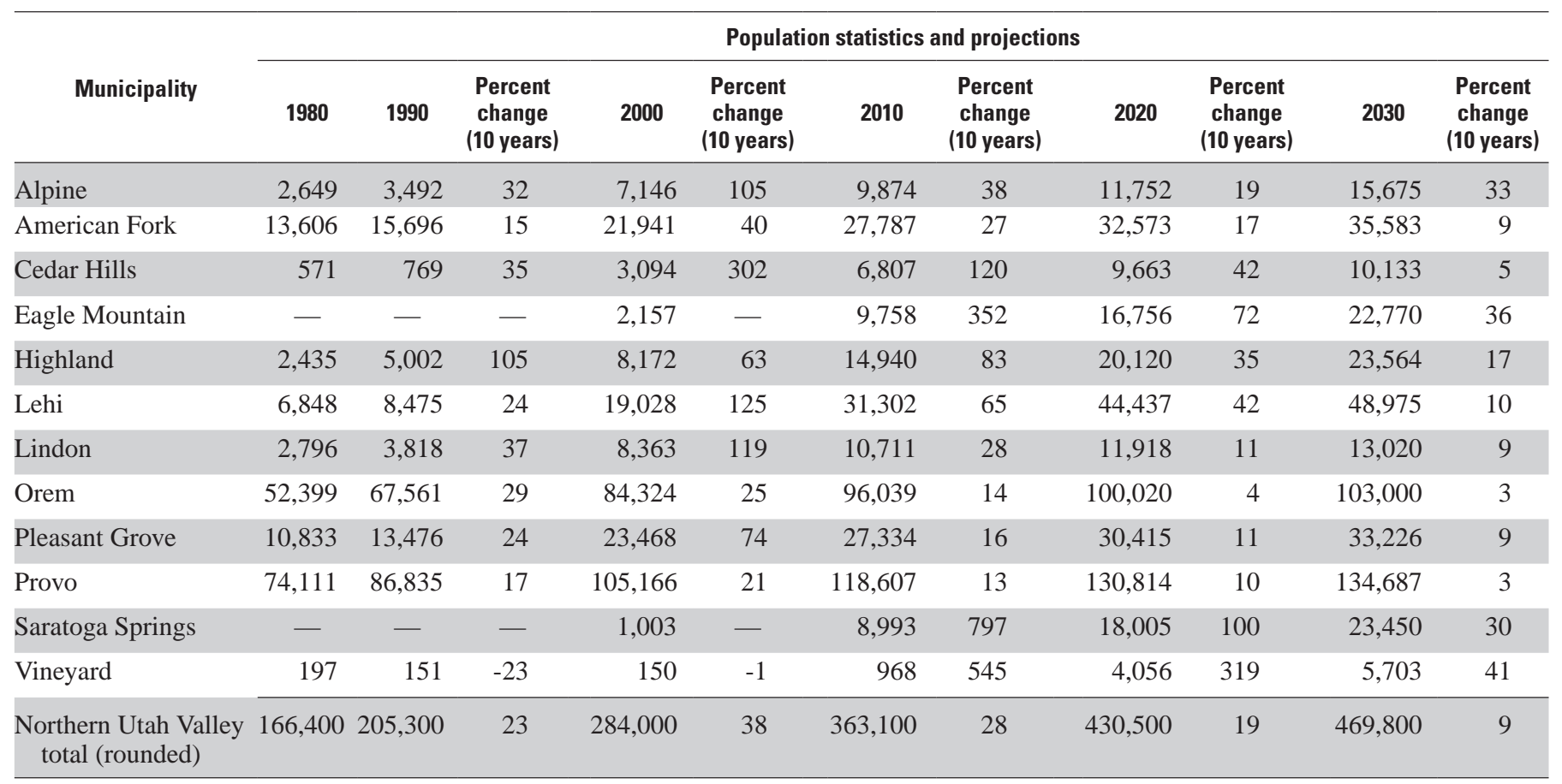

Table 3. Land-use change data for northern Utah Valley, Utah, 1966-2002.

[A bbreviation: -, no data]

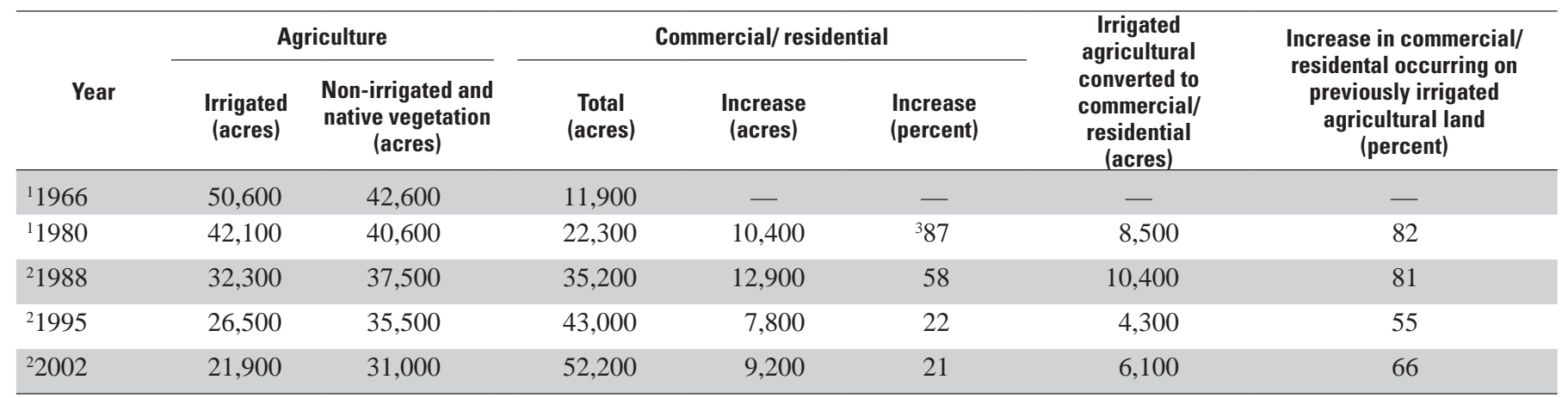

${ }^{1}$ Clark and Appel (1985, figures 5 and 6).

${ }^{2}$ Utah Department of Natural Resources (2004).

${ }^{3}$ Clark and Appel (1985) calculated a 58-percent increase in commercial/residential land use. The difference between datasets results from different study area dimensions, land-use classification methods, and methods of analysis. 


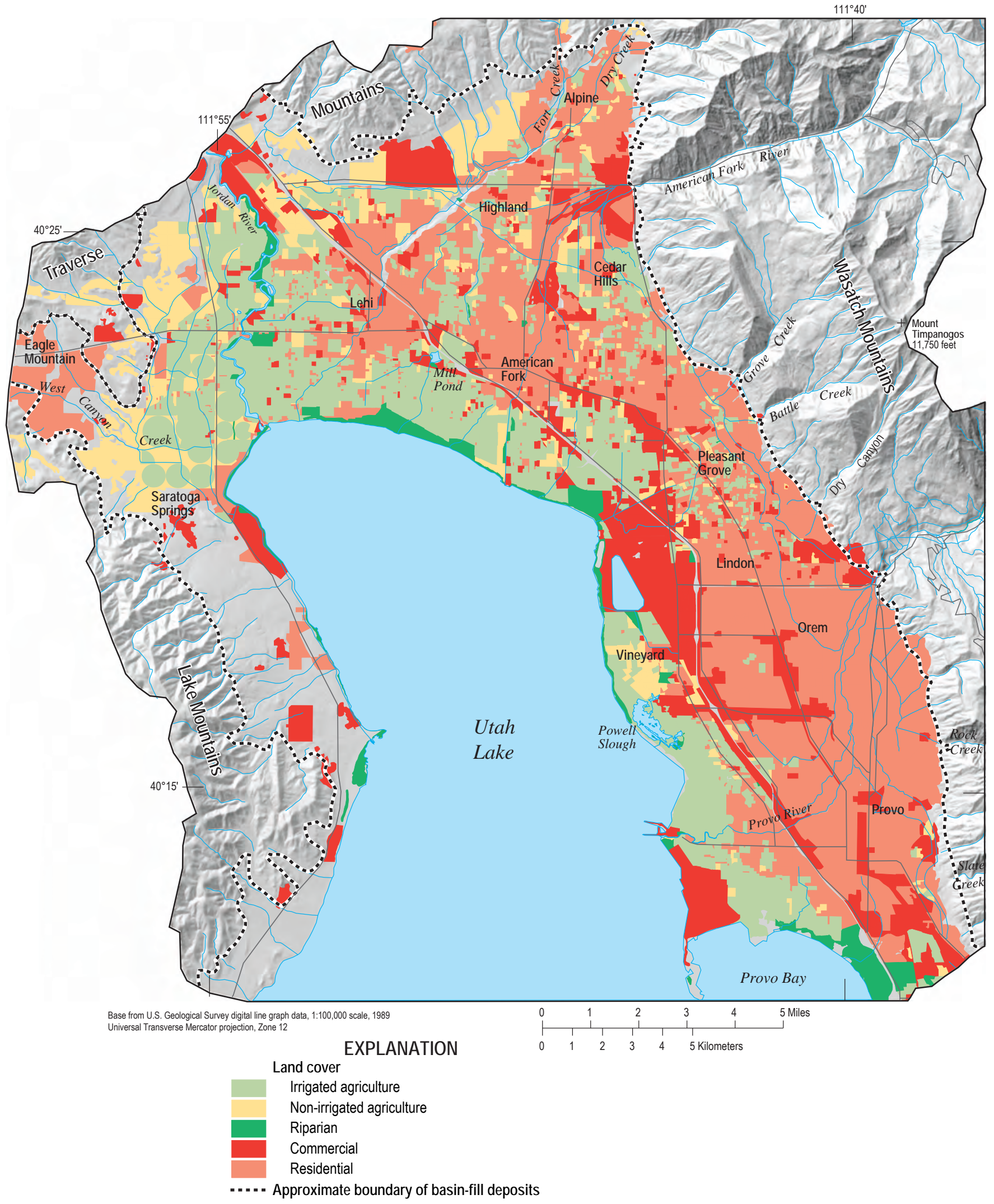

Figure 7. Distribution of land cover in northern Utah Valley, Utah, 2002. 
Their time and interest in discussions of their respective water works and water-use practices is greatly appreciated by the U.S. Geological Survey.

\section{Ground-Water Hydrology}

Ground water is the primary source of drinking water in northern Utah Valley and also is used for irrigation, stock watering, and industrial purposes. Productive aquifers are present in both the bedrock mountain blocks surrounding northern Utah Valley and in the unconsolidated basin-fill sediments in the valley. The basin-fill aquifers are the primary source of ground water and are collectively referred to herein as the principal aquifer. The majority of wells in the study area are completed within the basin-fill aquifers because of the ease of drilling, accessibility, and generally high-quality water that is suitable for domestic use. Increasingly, bedrock aquifers within the study area are being developed, especially in the area west of the Jordan River.

\section{Occurrence of Ground Water}

Richardson (1906) was the first to delineate separate confined aquifers in northern Utah Valley where he noticed different water levels in wells adjacent to each other but completed at different depths. Hunt and others (1953) further expanded the delineation of separate and distinct aquifers by dating the age of deposition for the sediments making up each aquifer. Clark and Appel (1985) also used the conceptual model of distinct and separate aquifers. They attempted to further delineate and date the period of deposition for the sediments in the deepest confined aquifer in sediments of Quaternaryand Tertiary-age (QT aquifer). Their attempts to enhance or verify the period of deposition as Quaternary or Tertiary were inconclusive. This study made no attempt to further date or verify previous ages but rather verifies the conceptual model of discrete and continuous confined aquifers.

The original conceptual model of the basin-fill aquifers in southern Utah Valley by Bissell (1963) was described as containing multiple confined aquifers, similar to northern Utah Valley. Brooks and Stolp (1995) reassessed the conceptualization in southern Utah Valley and, through the evaluation of new and old drillers' logs for wells completed throughout the area, determined that distinct and continuous aquifers could not be delineated for that part of the valley.

\section{Bedrock Aquifers}

Ground water occurs throughout the mountain blocks surrounding northern Utah Valley, and lateral subsurface flow from the bedrock uplands is considered a major source of water to the basin-fill aquifers (see "Subsurface Inflow" section of this report). Primary porosity in the competent bedrock is low, therefore limiting the movement and storage of ground water. Secondary porosity from faults and fractures within the bedrock mountain block allows for greater ground-water movement and storage. Secondary porosity within limestone is increased by dissolution channels as is evidenced by the caves at Timpanogos Cave National Monument in the American Fork River drainage basin.

Faulting is prevalent throughout northern Utah Valley with the Wasatch Fault zone separating the Wasatch Mountains from the down-dropped graben that forms the Utah Valley basin (fig. 8). The Wasatch Fault extends north along the Wasatch Mountains past American Fork Canyon as far as Dry Creek and follows Fort Creek along the east end of the Traverse Mountains, thereby separating the Traverse Mountains from the Wasatch Mountains block. The Traverse Mountains are composed of a highly fractured orthoquartzite conglomerate with a potentially high storage capacity. Beik (2003) mapped normal faults bounding the south and west flanks of the Traverse Mountains.

A series of normal faults trending north to south have been mapped beneath Utah Lake (fig. 8) (Hecker, 1993; Beik, 2003) and are interpreted to extend farther north along the Jordan River. Warmer ground water with elevated dissolvedsolids concentrations is present along and in the vicinity of these faults. Evaluation of well logs in the Eagle Mountain area (cross section A-A' on fig. 9) indicate faulting and associated graben structures in the area connecting Cedar Valley to northern Utah Valley.

\section{Unconfined Basin-Fill Aquifers}

Unconfined conditions occur throughout the valley, though the character of the unconfined aquifer varies laterally away from the mountain blocks to the valley center. The part of the unconfined aquifer toward the center of the valley that overlies the major confining layers is in fine-grained Lake Bonneville deposits (LB aquifer) (fig. 3). It is thin with shallow depths to water and generally does not produce a large volume of water. By contrast, the unconfined aquifer adjacent to the mountain blocks in pre-Lake Bonneville deposits (PLB aquifer), where the confining layers are thin and discontinuous or absent, consists of thick, coarse-grained, permeable deposits that extend laterally beneath the confining layers (fig. 3).

The shallow unconfined LB aquifer generally occurs lower in the valley along the base of the benches and extends into the valley bottom. In areas higher on the benches, where the layers of fine-grained sediments that form the base of the LB aquifer are discontinuous, small perched aquifers may be present. The Lake Bonneville sediments generally consist of clay, silt, and sand grading to low permeability clays at depths ranging from 5 to $40 \mathrm{ft}$ below land surface. The low permeability clay layer is extensive and continuous across the lower part of the valley and forms the uppermost confining unit (CF1). East of the Jordan River, the clay is typically characterized as low permeability blue clay on well drillers' logs. West of the Jordan River, the character of the clay is generally similar except it is often noted as having a tan color. The water 


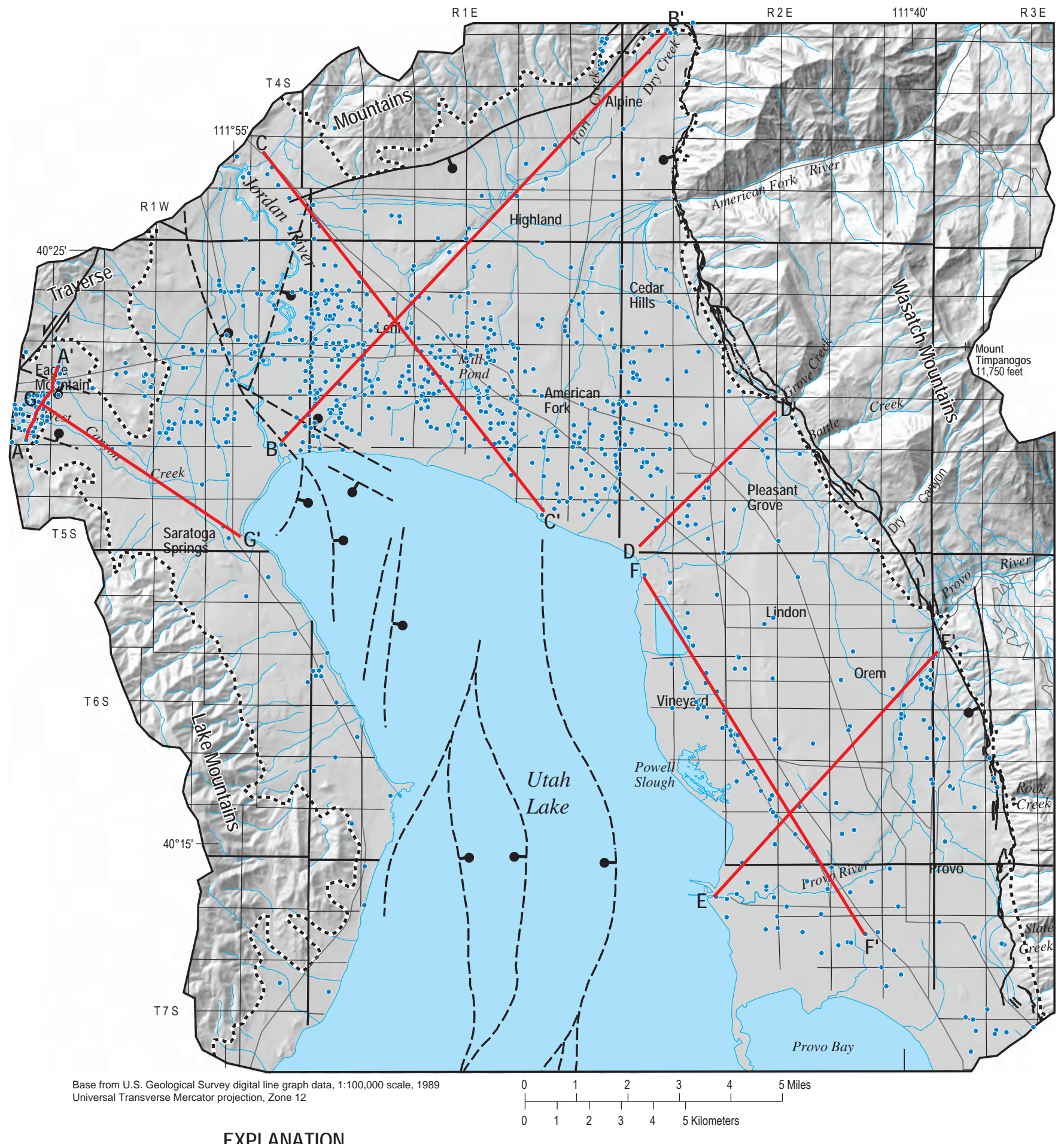

EXPLANATION

$A$ - A Location of cross-section and fence diagram transects

$--\boldsymbol{\zeta}$ Fault- $-\boldsymbol{d}$, indicates movement of the downthrown block, dashed where approximate

.... Approximate boundary of basin-fill deposits

- Well with lithologic information used in hydrostratigraphic framework

Figure 8. Location of wells with lithologic information and cross sections in the northern Utah Valley study area, Utah. 


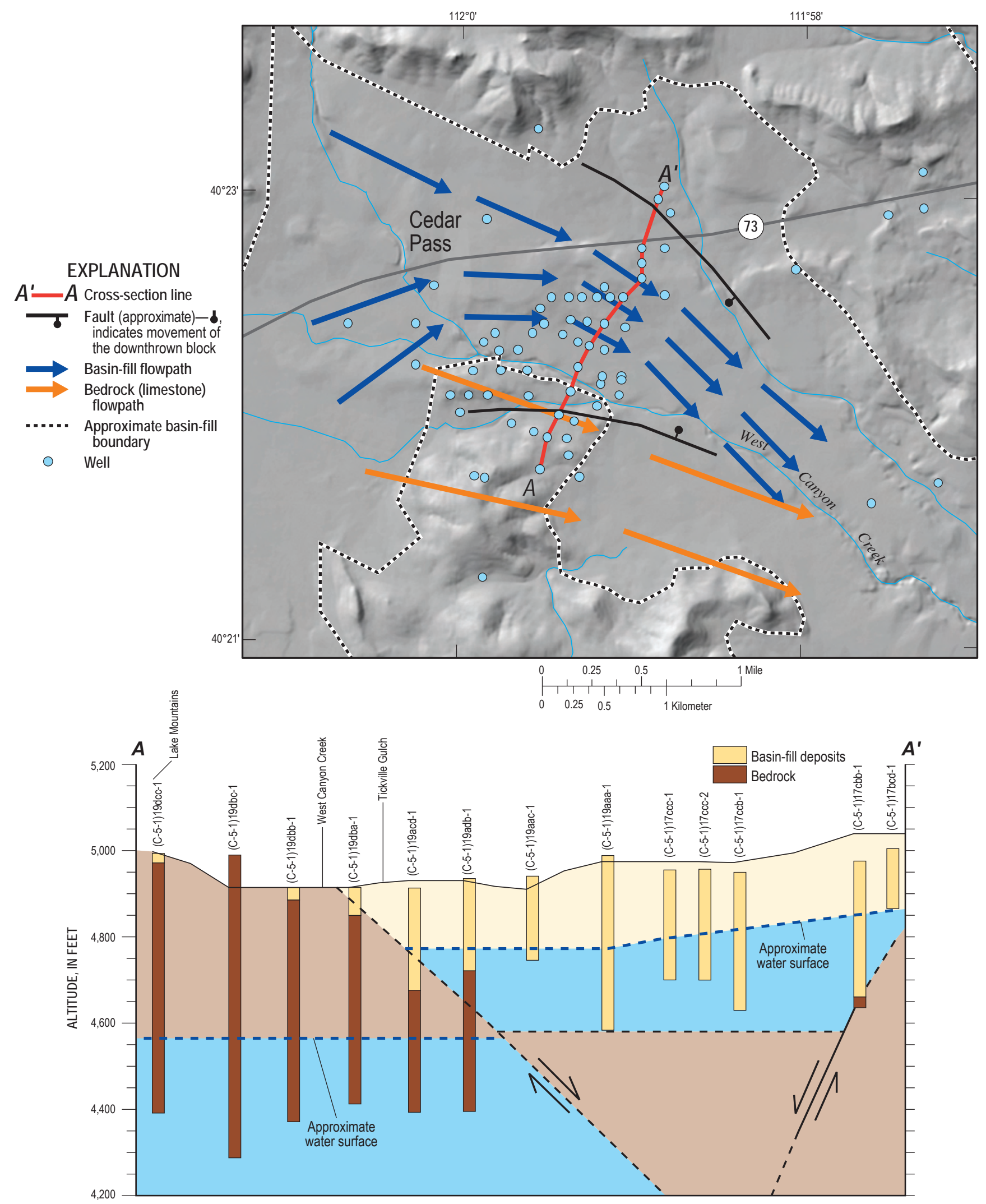

Figure 9. Cross section and effect of faults on flowpaths in the basin-fill deposits and bedrock in the Cedar Pass area, northern Utah Valley study area, Utah. 
table of the LB aquifer is generally within tens of feet of the land surface. Use of this aquifer is mostly limited to smallscale irrigation because of low production and poor water quality relative to the deeper aquifers.

The sediments that make up the unconfined PLB aquifer generally consist of unconsolidated sand, coarse to very coarse gravel, cobble, and boulder deposits. Layers of clay and silt are thin and discontinuous, allowing easy infiltration of surface water entering the valley from the mountain blocks. This area is the major zone of surficial recharge to the confined aquifers present in the center of the valley. The width of the unconfined zone varies widely depending on the relative location to major canyons in the adjacent mountain blocks. Closer to the canyon mouths, where more surface water and source material are available, large alluvial fans and deltaic deposits dominate. The high-energy environment re-distributes coarsergrained sediments and removes most of the fine-grained sediments deposited close to the canyon mouth. In general, the PLB aquifer ranges from about $200 \mathrm{ft}$ wide in the southern part of the study area to more than $1 \mathrm{mi}$ wide in the Highland/ Alpine area. The thickness of the deposits in the PLB aquifer also varies, ranging from less than $300 \mathrm{ft}$ adjacent to the western mountain block to more than $1,550 \mathrm{ft}$ along the eastern and northern mountain blocks. Depth to water is dependent on the altitude of the land surface and can range from about 150 $\mathrm{ft}$ near the mouth of the Provo River to $400 \mathrm{ft}$ in the Highland area.

\section{Confined Basin-Fill Aquifers}

Hunt and others (1953) originally distinguished three confined aquifers in the basin-fill deposits of northern Utah Valley based on their relative depths and suspected age of sediment deposition associated with each aquifer. The naming convention applied with depth is: the shallow confined aquifer in deposits of Pleistocene age (SP aquifer), the deep confined aquifer in deposits of Pleistocene age (DP aquifer), and the confined aquifer in deposits of Quaternary/Tertiary age (QT aquifer). Each aquifer is a lateral continuation of the PLB aquifer with multiple clay and silt units acting as confining layers between aquifers (fig. 3). The clay and silt units originate away from the mountain front and thicken toward the lowest parts of the valley. The confining clay units and the deposits forming the aquifers are generally laterally extensive, although locally the units may be thin or non-existent and difficult to correlate among wells.

The SP aquifer is the shallowest confined aquifer in northern Utah Valley and occurs throughout the middle and lower parts of the basin (fig. 10). The aquifer generally consists of deposits of silt, sand, and gravel with a thickness ranging from 10 to $150 \mathrm{ft}$. It underlies the uppermost confining unit (CF1), a blue clay layer that is the most distinguishable and continuous layer identifiable in drillers' logs. This confining unit ranges in thickness from 50 to $150 \mathrm{ft}$. In many drillers' logs, the SP aquifer deposits are noted to occur at depths of 90 to $120 \mathrm{ft}$ below land surface. Underlying the SP aquifer is the next major confining clay layer (CF2) that is often described in drillers' logs as blue or tan clay with a highly variable thickness ranging from 10 to $200 \mathrm{ft}$.

The DP aquifer may be the most extensive aquifer within the valley because it occurs both near the mountain front and in the lower parts of northern Utah Valley (fig. 10). The DP aquifer is highly variable in thickness and locally may consist of multiple coarser material layers separated by thin clay and silt layers. The aquifer consists of mixed sands and gravels close to the mountain front and grades to silty sand near the valley lowlands. Near Lehi and American Fork, the aquifer often is present at depths of about 180 to $200 \mathrm{ft}$ below land surface and generally has a thickness of about $100 \mathrm{ft}$. Near Pleasant Grove, Geneva, and Vineyard, the depth of the DP aquifer is generally from 250 to $325 \mathrm{ft}$ below land surface with thickness varying from 50 to $200 \mathrm{ft}$. Often, wells do not fully penetrate the DP aquifer and thicknesses listed on drillers' logs may not represent the full thickness of the aquifer. When penetrated, the underlying clays forming the lowest confining unit (CF3) are described as white clays, hardpan, or conglomerate.

The QT aquifer is the least penetrated, developed, and documented aquifer in the basin-fill deposits of northern Utah Valley. Deposits are often described in drillers' logs as coarsegrained gravels and sands interbedded with clays and silts that are not correlated among wells and are assumed to be discontinuous. The thickness of the QT aquifer is not known but is at least $600 \mathrm{ft}$ in the vicinity of Vineyard. Most wells drilled into the QT aquifer do not penetrate the aquifer more than a few hundred feet before adequate water is supplied to the well.

The unconsolidated sediments west of the Jordan River and Utah Lake are described in drillers' logs much the same as the QT aquifer deposits are described, consisting of coarse gravels and sands interbedded with clays and silts. The uppermost fine-grained clays west of the Jordan River and Utah Lake are described as having a light tan color rather than the distinctive blue color described of the fine-grained sediments to the east of the Jordan River in CF1. Limestone bedrock has been penetrated at about $300 \mathrm{ft}$ in wells drilled adjacent to the west shore of Utah Lake and west of the Jordan River. The Utah Lake fault zone traverses the area along the west side of Utah Lake and along the Jordan River corridor. This likely has offset the sediments west of the Jordan River relative to sediments to the east. Because of these differences, the associated confining unit and aquifer west of Utah Lake and the Jordan River are designated separately as confining unit 4 (CF4) and the western unconsolidated aquifer (WU), respectively (fig. 10). Even though the units are designated separately, it is assumed that they are hydraulically connected to designated units CF1 and the SP aquifer to the east. As in the eastern side of the valley, unconfined aquifer conditions are present near the mountain front of the Lake Mountains and Traverse Mountains but change to confined conditions in the valley lowlands. 


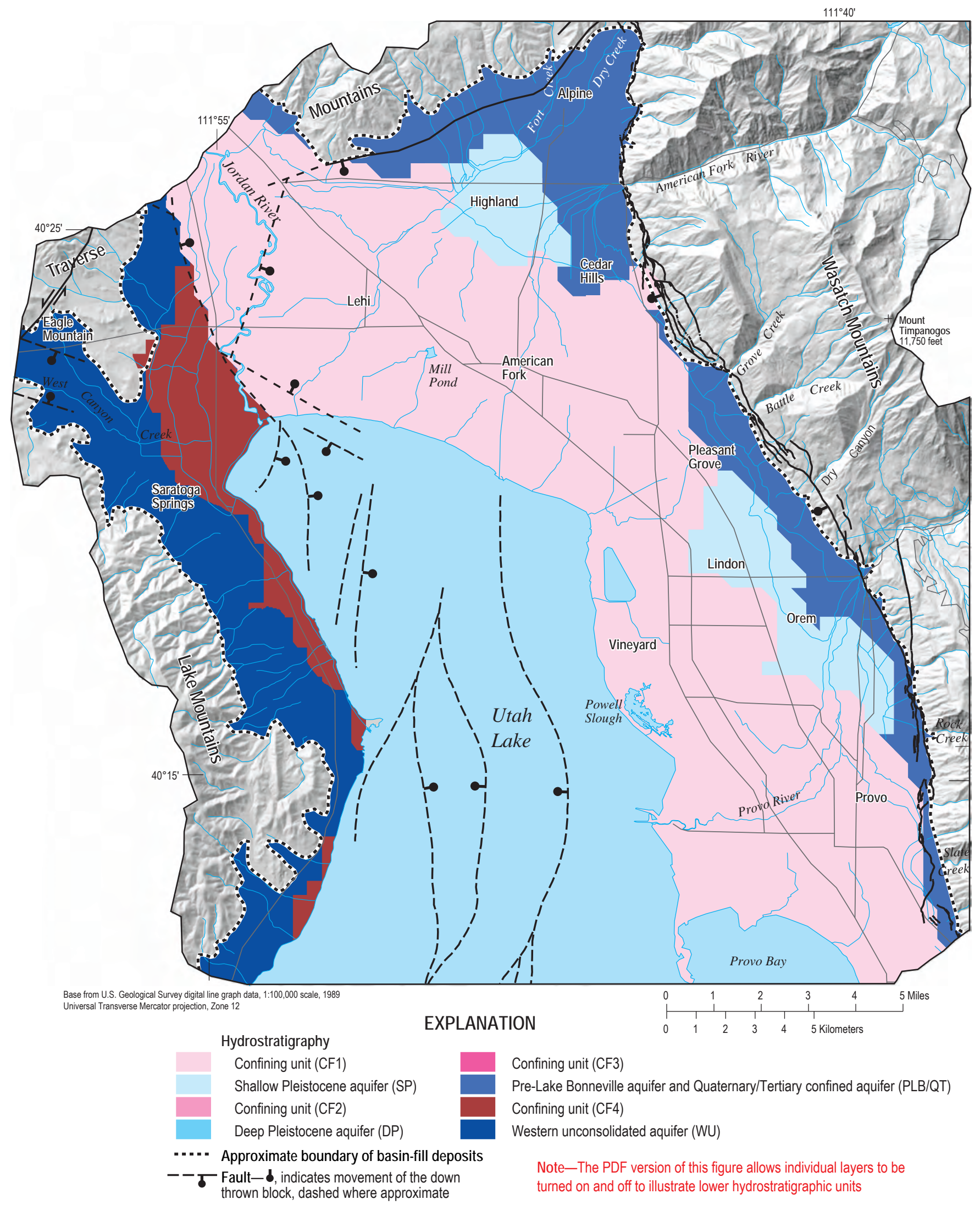

Figure 10. Extent of the basin-fill aquifers and confining units as determined from the hydrostratigraphic framework, northern Utah Valley, Utah. 


\section{Hydrostratigraphic Framework}

A three-dimensional hydrostratigraphic framework was developed to represent the extent, both areally and at depth, of the aquifers and confining units composing the principal basin-fill aquifer in northern Utah Valley. The framework units were delineated by using 924 lithologic logs from wells throughout the study area. Individual framework units were constructed by using a computer program to interpolate a surface between the delineated points to represent the contact between hydrostratigraphic units. The hydrostratigraphic framework was developed to be used in the numerical groundwater flow model being developed concurrently (2007).

The State of Utah Department of Natural Resources, Division of Water Rights, maintains an electronic archive of drillers' logs for newly drilled wells and a subset of historical drillers' logs. In total, 675 drillers' logs were used from those entered into the Division of Water Rights database through October 2004. An additional 249 drillers' logs were entered into the database by USGS personnel. A total of 924 drillers' logs were used with 867 of the logs from wells located within the study area boundary (fig. 8).

In order to compare lithologic descriptions from a variety of sources, drillers' logs were simplified to represent gross lithologic conditions as noted during drilling. This simplification included interpretation of the lithologic descriptions in order to normalize the subjective nature of the logs. Drillers' logs submitted to the State of Utah are required to include the different types of material encountered (clay, silt, sand, gravel, cobble, boulder) at a specific depth, but the percentage of each is generally not documented on the log. All different combinations of sediments were considered and grouped in the same manner so that every interval in a log could be generalized as clay, silt, sand, gravel, cobble, boulder, hardpan, or bedrock. Simplification included designating groupings of sediment types into specific classes of the dominant material that likely controls the gross hydraulic properties at the noted depth. For example, on a log noting clay and silt at a specific depth, the clay and silt were lumped together and considered to represent the gross hydraulic properties of clay, whereas a section noted as having silt and sand at the same depth was considered to have the gross hydraulic properties of sand. Wells with lithologic information are represented in three-dimensional space in figure 11.

Logs were interpreted individually without knowledge of the location of the well in order to determine if specific and distinct confining units and aquifers could be determined from lithology only. Gross changes in lithology as noted on drillers' logs were the primary indicators of the hydraulic properties encountered during drilling. In addition, substrate characteristics noted by drillers, including color, texture, and presence of water, were used to help delineate aquifers or confining units. Delineation of the shallow unconfined (water-table) LB aquifer was not attempted because most drillers' logs completed in northern Utah Valley do not address the occurrence of this low-yielding aquifer. As a result, all material above the first occurrence of a clay layer or above the water table in the preLake Bonneville deposits was classified as overburden.

Hydrostratigraphic unit delineation, based on the simplified lithology, was completed for the majority of the interpreted lithologic logs. Logs for wells occurring along the mountain front generally had no discernable confining unit, whereas logs for relatively deep wells in the lower part of the valley could consistently be characterized as having at least one or two confining units at representative depths. The majority of logs are consistent with the aquifers and confining units represented in the conceptual models described by Hunt and others (1953) and Clark and Appel (1985).

Correlation of the interpreted hydrostratigraphic units among wells was done to generate surfaces that represent the top of each hydrostratigraphic unit within the framework. Generation of the hydrostratigraphic unit surfaces was done by using a computer program with an automated technique for determining the Kriging method with the least amount of uncertainty based on the variance of the Kriging algorithm (Rockware, 2004). The technique uses the variance between adjacent wells to determine a best-fit location within a 1,640 by $1,640 \mathrm{ft}(500$ by $500 \mathrm{~m}$ ) grid covering the extent of the basin-fill deposits in northern Utah Valley. The Kriging method works well at defining directional trends, such as surface expression. To avoid clustering effects of adjacent wells, the data were normalized to a 164 by $164 \mathrm{ft}$ ( 50 by $50 \mathrm{~m}$ ) grid by taking the average of all data points within that grid. The variance near a data source is generally low but increases, along with uncertainty, as distance from the data source increases. Few data are available for the mountain block near the boundary with the valley basin-fill sediments, and no data are available for the area covered by Utah Lake (fig. 10). The lack of data generates a great deal of uncertainty within these areas. The interpreted hydrostratigraphy at the mountain block/ valley basin-fill sediment boundary was delineated solely by the delineated boundary by Anderson and others (1994). The interpreted hydrostratigraphy underlying Utah Lake was interpolated and extrapolated from well data adjacent to the lake on the east side of the valley with the assumption that the aquifer material becomes finer grained as the distance from the mountain front increases. Because Utah Lake is a remnant of ancient Lake Bonneville and other paleolakes, lacustrine deposition likely has been a dominant process in the valley bottom throughout much of the Quaternary Period and into the Tertiary Period. The Utah Lake fault zone was generalized and represented as a single fault extending from the south boundary to the north boundary. The generalized fault represents the boundary between hydrostratigraphic units on the east and west sides of northern Utah Valley (fig. 10).

The density of collected data decreases with depth where fewer wells penetrate into the deeper aquifers, especially the QT aquifer. The lack of data collected at depth increases the uncertainty in the hydrostratigraphic surface for the deeper aquifers. An additional limitation of interpolation is that most wells do not fully penetrate the aquifer that they are completed in. This provides an upper contact between units but not an 


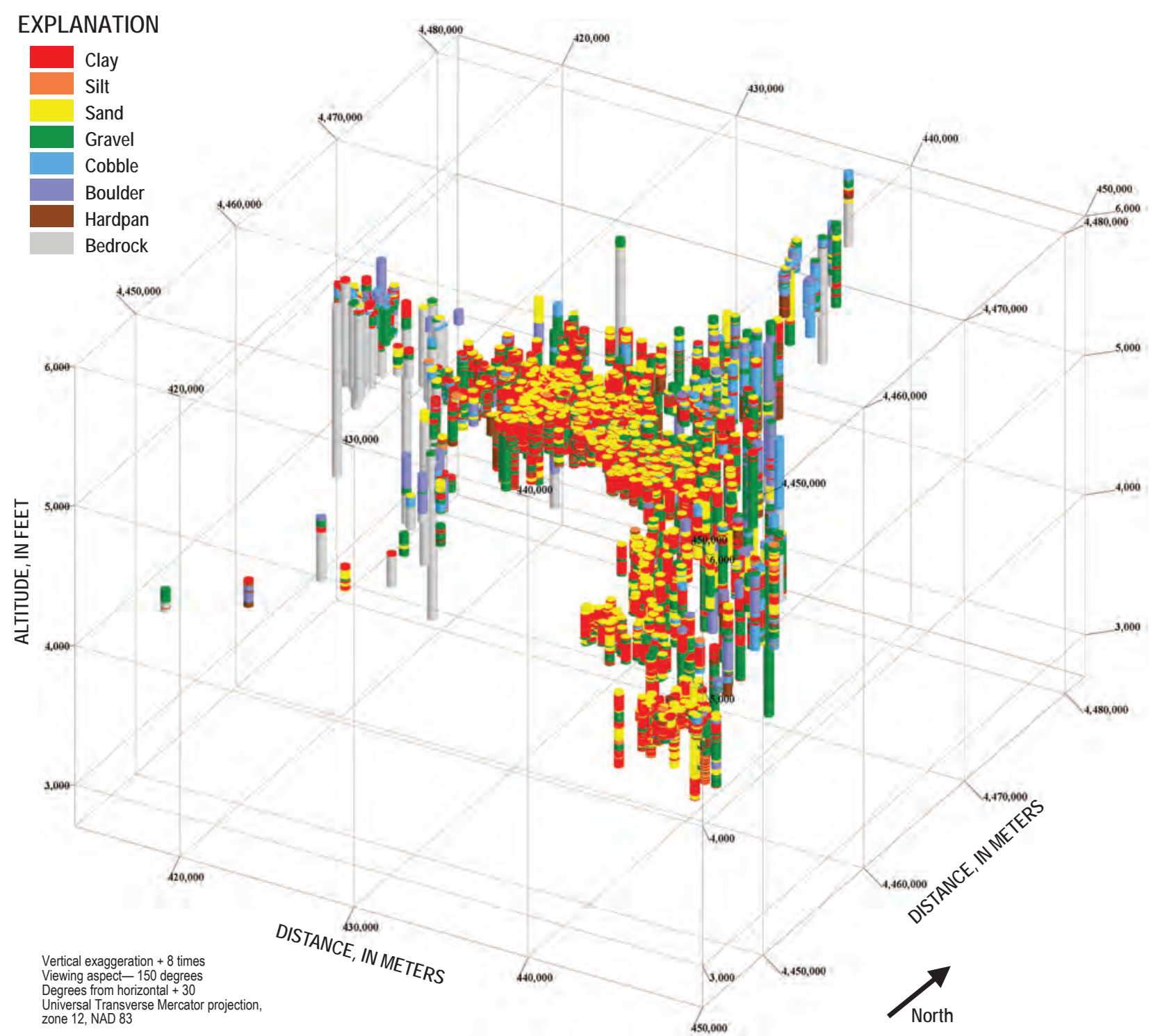

Figure 11. Three-dimensional representation of wells with lithologic information used for development of a hydrostratigraphic framework, northern Utah Valley, Utah.

absolute thickness of the lowest unit drilled into, which is most often an aquifer unit. A fence diagram (fig. 12) represents the vertical extent of the hydrostratigraphic units along different cross sections of the basin-fill deposits (figs. 13, 14, 15, and 16). The location of each cross section is shown in figure 8.

Hydrostratigraphic framework units are represented as a surface layer with top elevation and thickness represented for each 500-m cell within the hydrostratigraphic framework (fig. 12). Each individual hydrostratigraphic unit may be represented as a single unit or as a grouped model with each unit represented. The extent of each hydrostratigraphic unit representing the aquifers (SP, DP, QT, and WU), as well as the associated confining unit, is illustrated in figure 10 . Hydrostratigraphic units extend laterally to the mountain front and adjoin to the unconfined PLB aquifer as described previ- ously. In order to simplify development of the hydrostratigraphic framework, designation of the unconfined PLB aquifer unit was joined to the QT aquifer unit; therefore, the QT aquifer unit also represents the PLB aquifer unit within the hydrostratigraphic framework. The SP, DP, and WU aquifers are considered nearly continuous lateral extensions of the unconfined PLB aquifer. Where the confining unit overriding each respective aquifer is absent, the aquifer is assumed to connect to the combined PLB and QT aquifer hydrostratigraphic framework unit. 


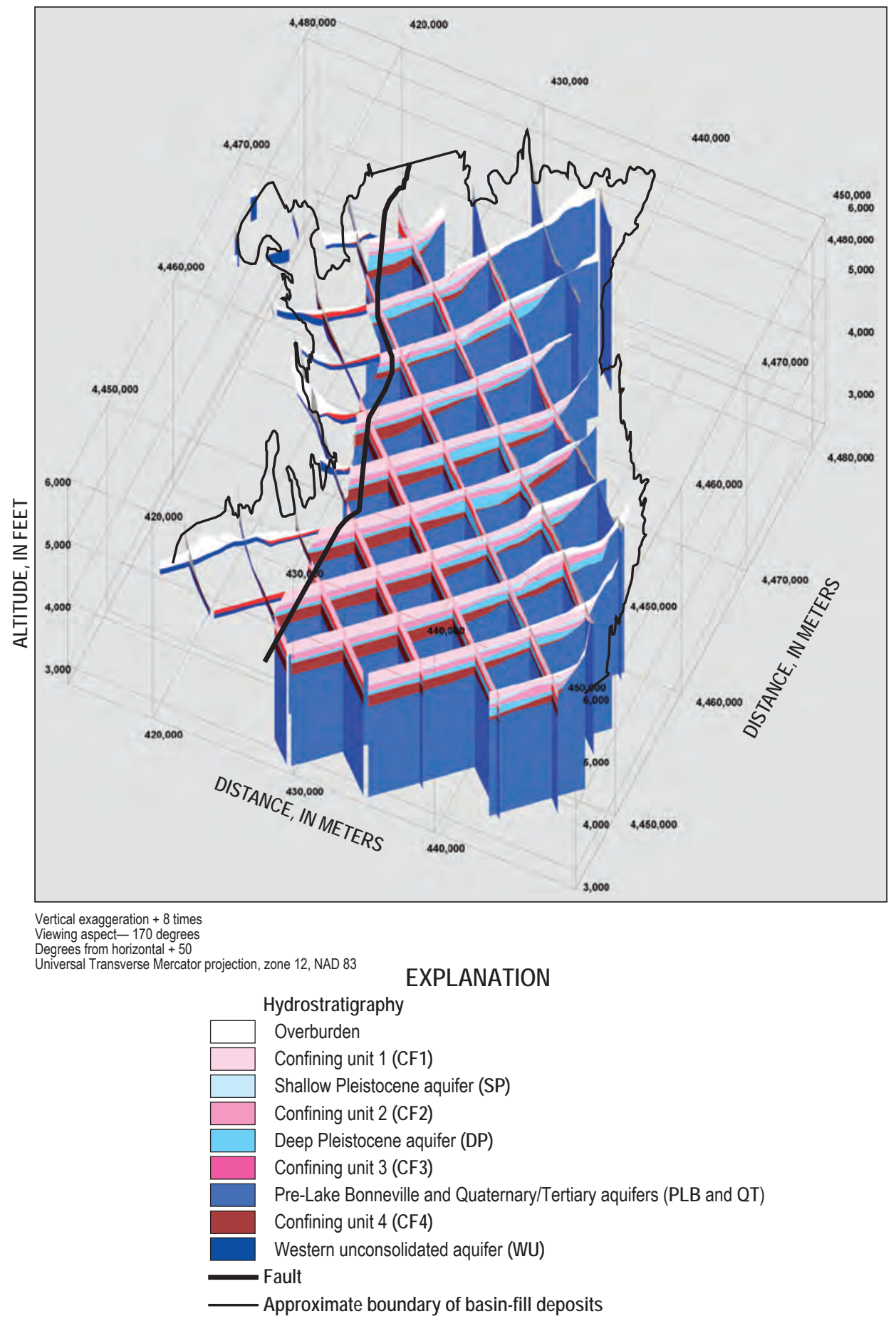

Figure 12. Fence diagram representing the hydrostratigraphic framework of the principal basin-fill aquifer in northern Utah Valley, Utah. 


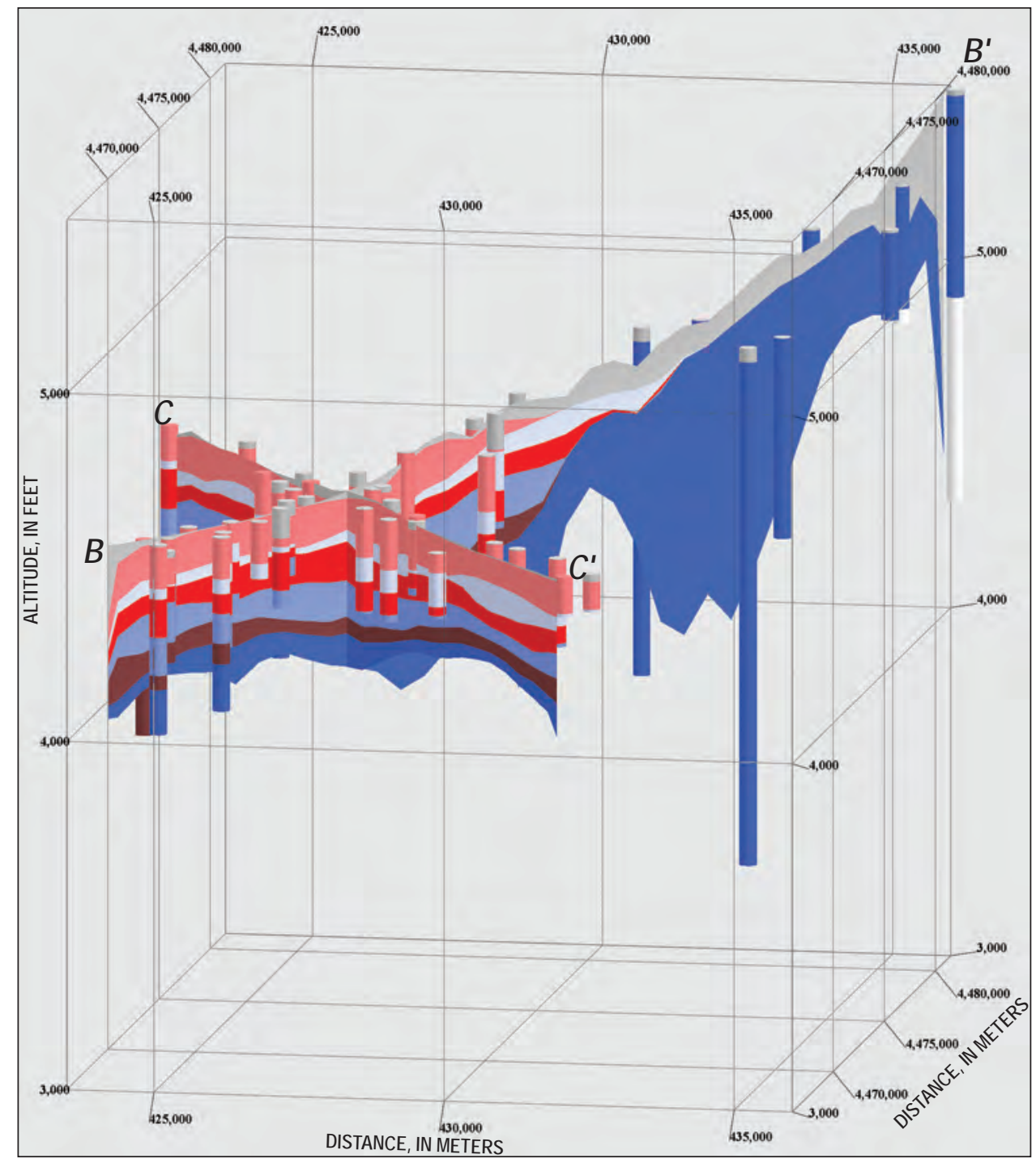

Vertical exaggeration +3 times
Viewing aspect- 170 degrees

Degrees from horizontal + 10
Universal Transverse Mercator projection, zone 12, NAD 83

\section{EXPLANATION}

Hydrostratigraphy

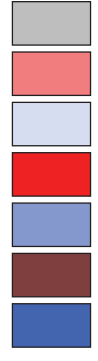

Overburden

Confining unit 1 (CF1)

Shallow Pleistocene aquifer (SP)

Confining unit 2 (CF2)

Deep Pleistocene aquifer (DP)

Confining unit 3 (CF3)

Pre-Lake Bonneville and Quaternary/Tertiary aquifers (PLB and QT)

$A^{\prime}$ - A Location of cross-section and fence diagram transects

- - - Approximate boundary of basin-fill deposits

- - - F - Fault- d, indicates movement of the downthrown block, dashed where approximate

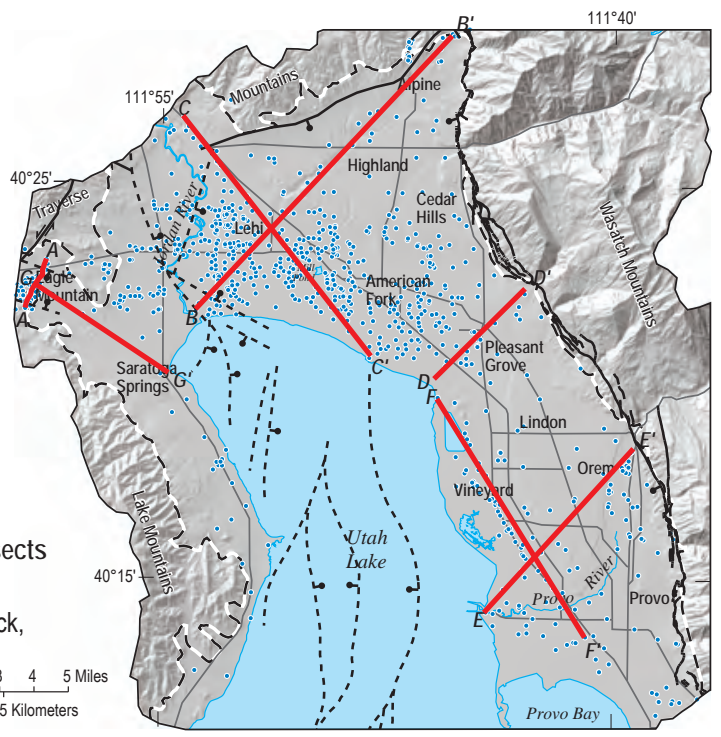

Figure 13. Cross sections representing the hydrostratigraphic framework along Dry Creek (B-B') and across the valley floor from the Jordan Narrows to Utah Lake at American Fork (C-C'), northern Utah Valley, Utah. 


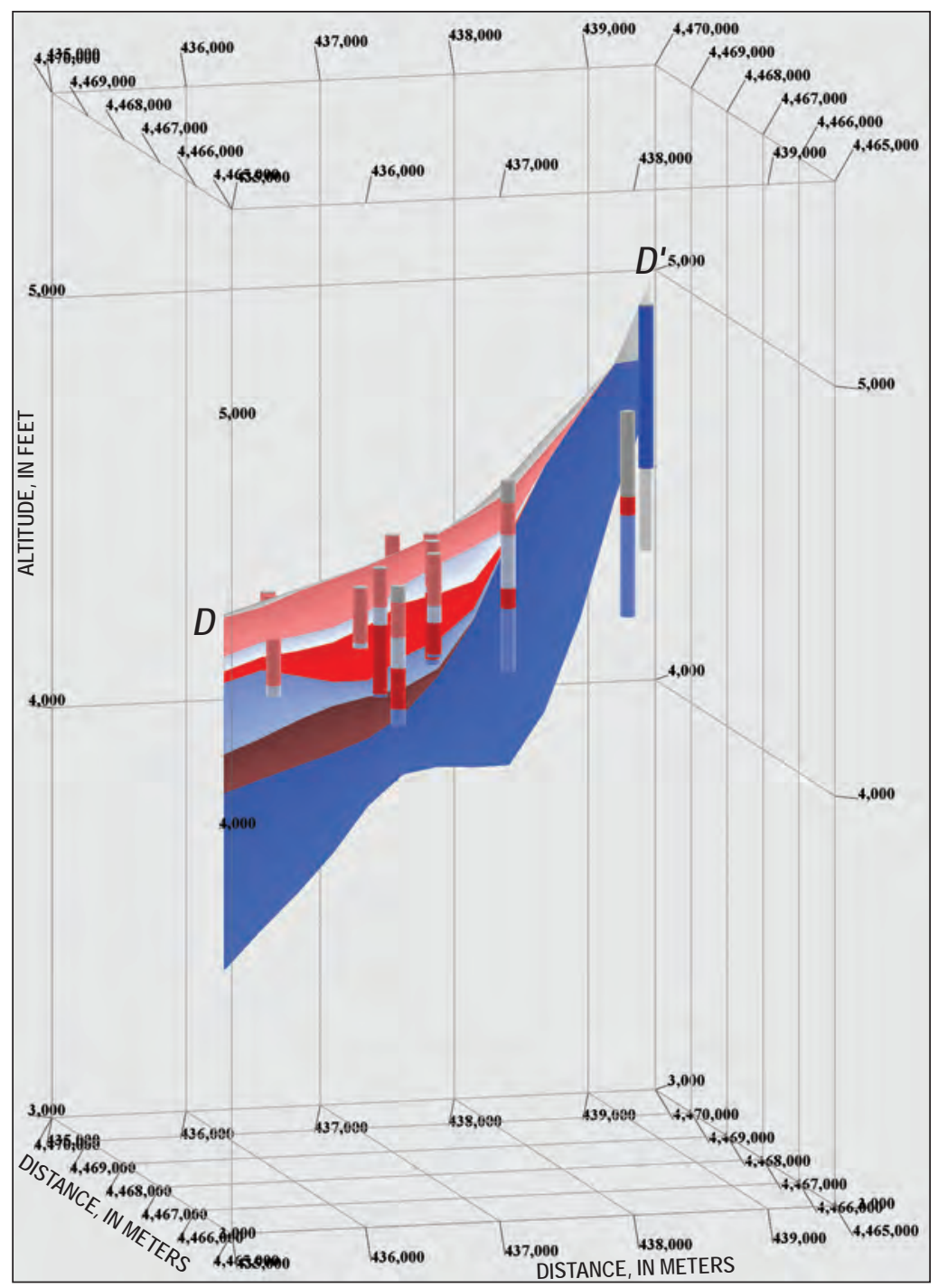

Vertical exaggeration +3 times Viewing aspect-190 degrees
Degrees from horizontal +15

Universal Transverse Mercator projection, zone 12, NAD 83

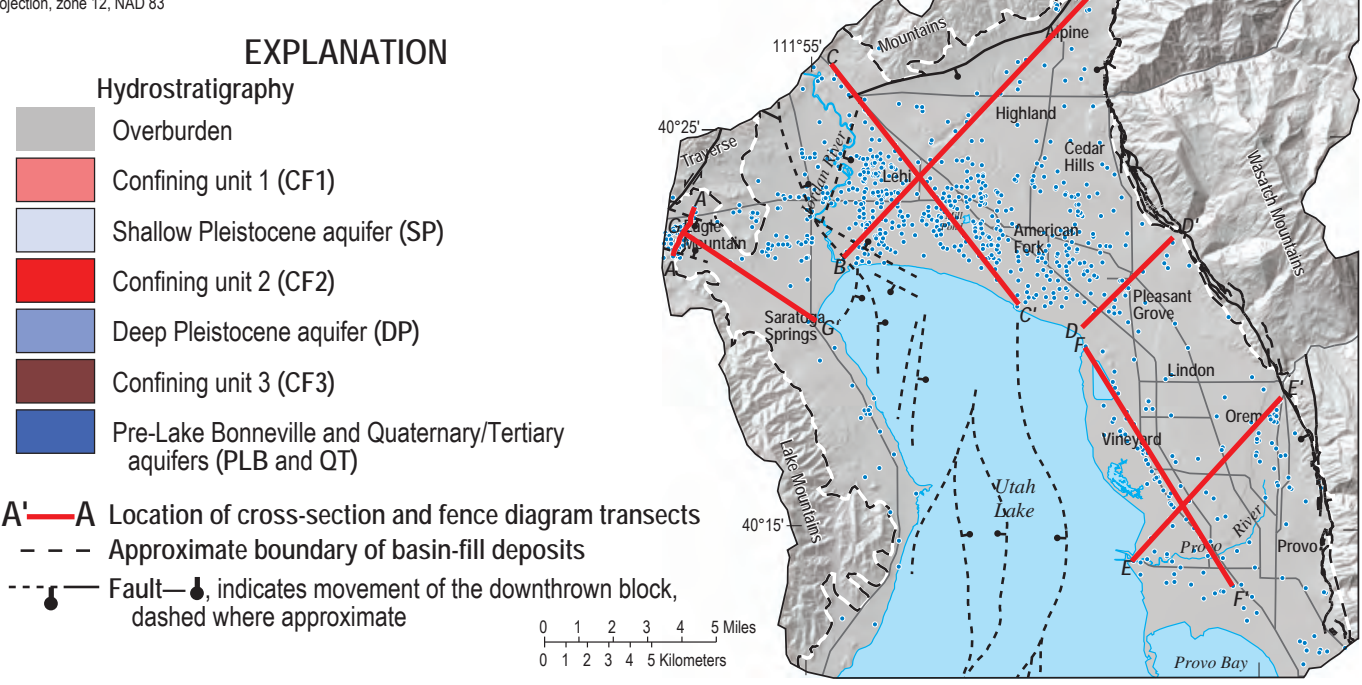

Figure 14. Cross section representing the hydrostratigraphic framework along Battle Creek near Pleasant Grove (D-D'), northern Utah Valley, Utah. 


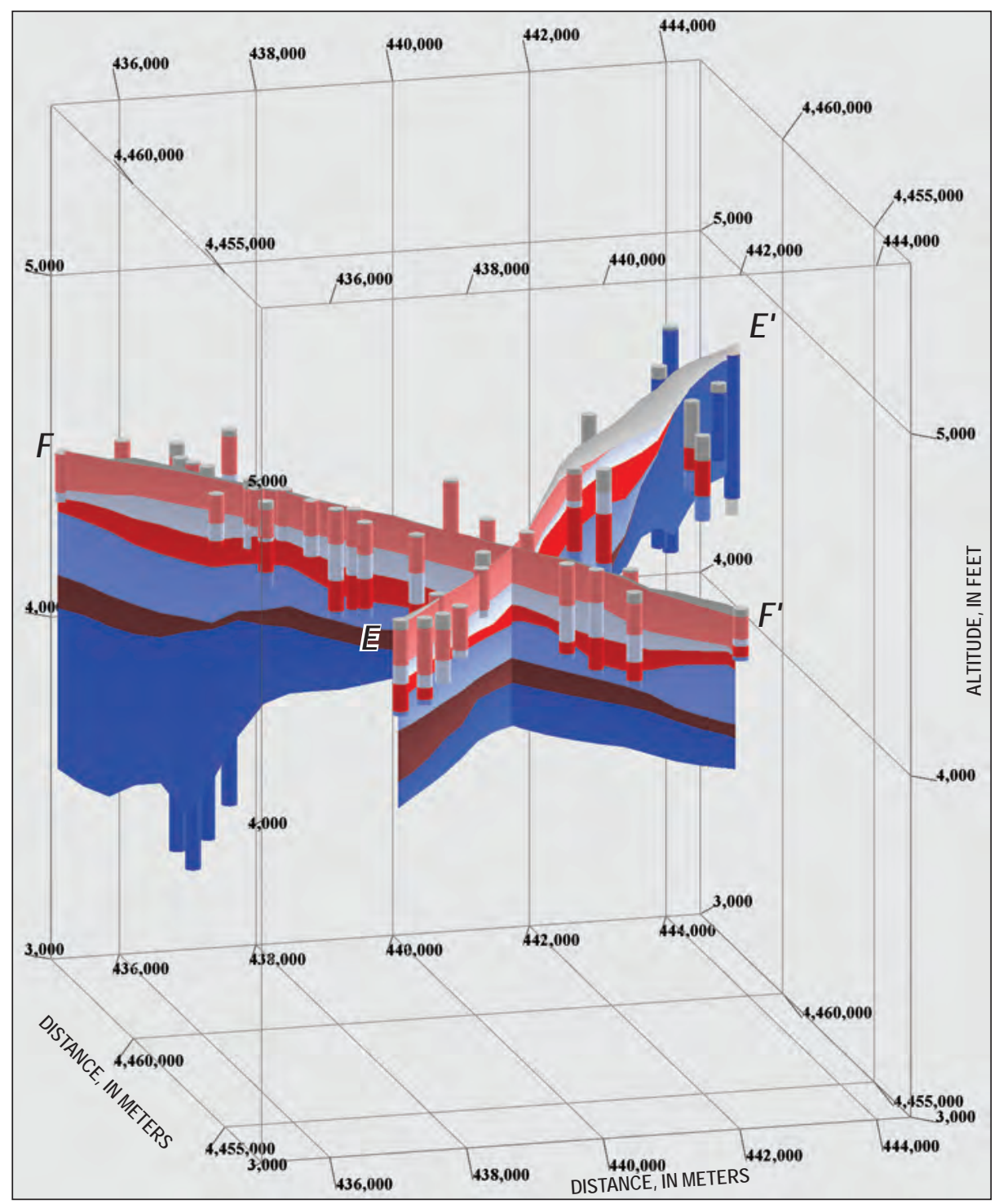

Vertical exaggeration +5 times

Viewing aspect -195 degrees
Degrees from horizontal +15

Universal Transverse Mercator projection, zone 12, NAD 83

\section{EXPLANATION}

Hydrostratigraphy

Overburden

Confining unit 1 (CF1)

Shallow Pleistocene aquifer (SP)

Confining unit 2 (CF2)

Deep Pleistocene aquifer (DP)

Confining unit 3 (CF3)

Pre-Lake Bonneville and Quaternary/Tertiary aquifers (PLB and QT)

$A^{\prime}-A$ Location of cross-section and fence diagram transects

- - - Approximate boundary of basin-fill deposits

- - $\boldsymbol{\delta}$ - Fault- $\boldsymbol{d}$, indicates movement of the downthrown block, dashed where approximate

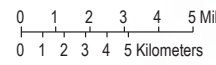

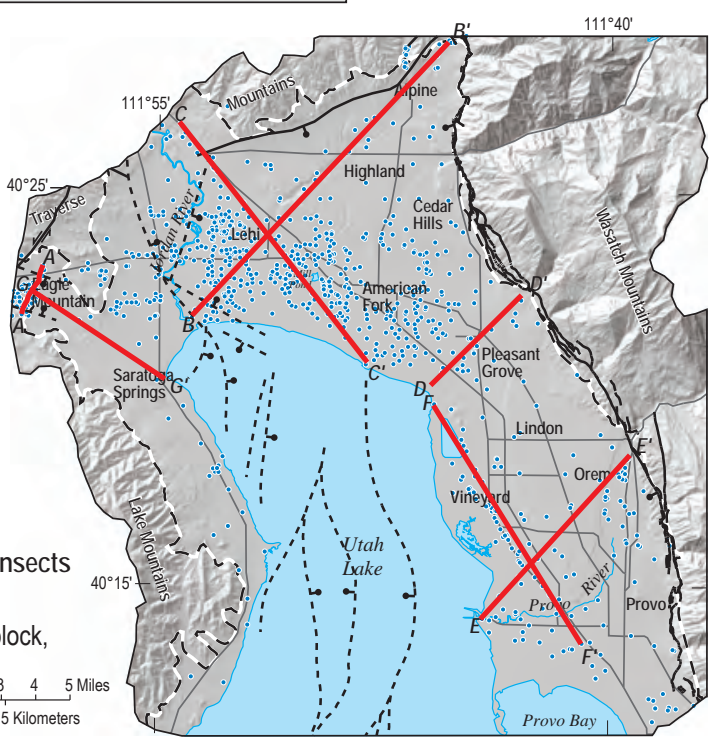

Figure 15. Cross sections representing the hydrostratigraphic framework from Utah Lake at Provo River to Provo Canyon (E-E') and from Geneva to near Provo Bay (F-F'), northern Utah Valley, Utah. 


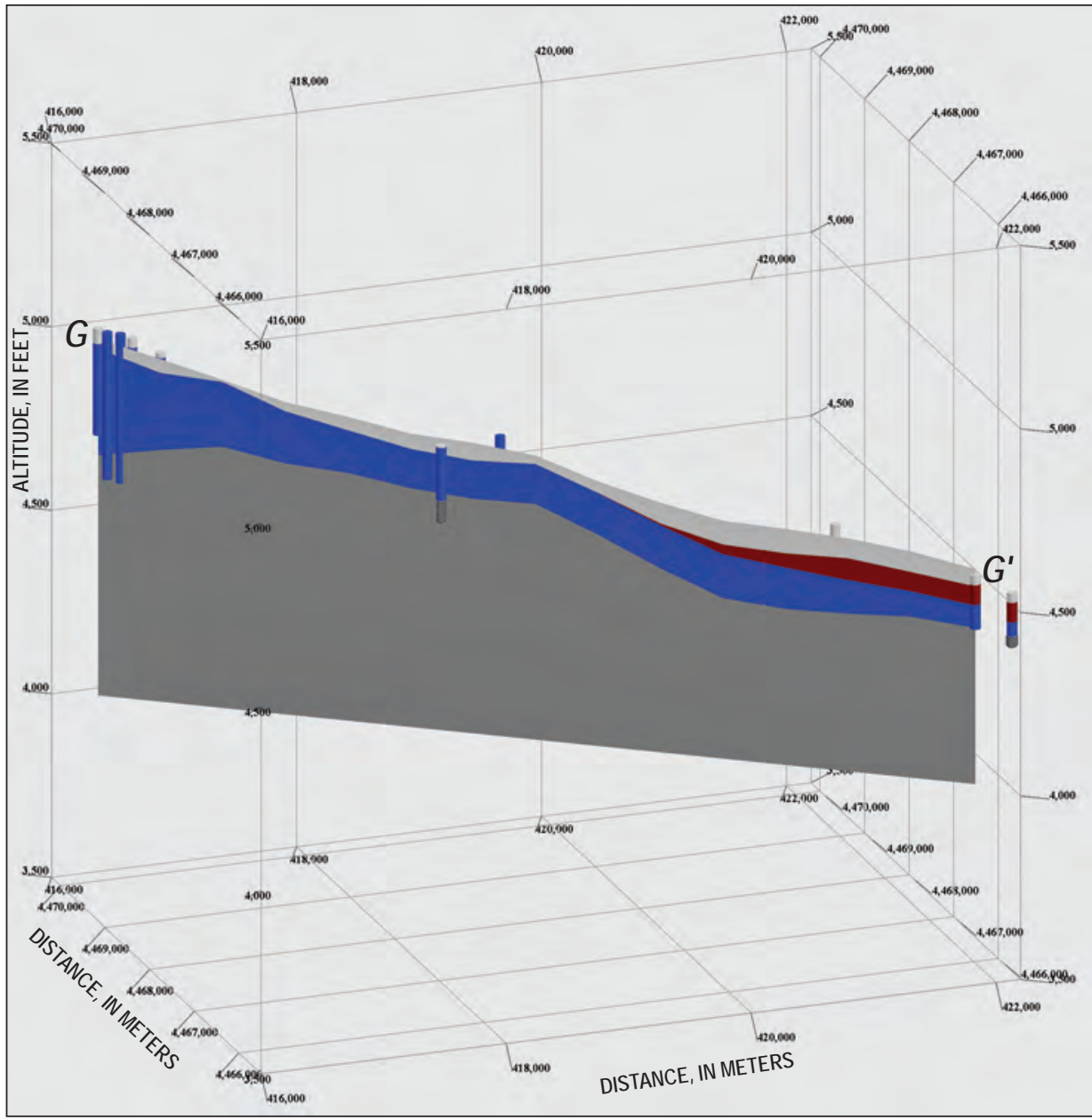

Vertical exaggeration +3 times

Viewing aspect -200 degrees
Degrees from horizontal +20

Universal Transverse Mercator projection, zone 12, NAD 83

\section{Hydrostratigraphy}

EXPLANATION

Overburden

Confining unit 4 (CF4)

Western unconsolidated aquifer (WU)

Bedrock

A'-A Location of cross-section and fence diagram transects

- - - - Approximate boundary of basin-fill deposits

- - Fault - d indicates movement of the downthrown block, dashed where approximate

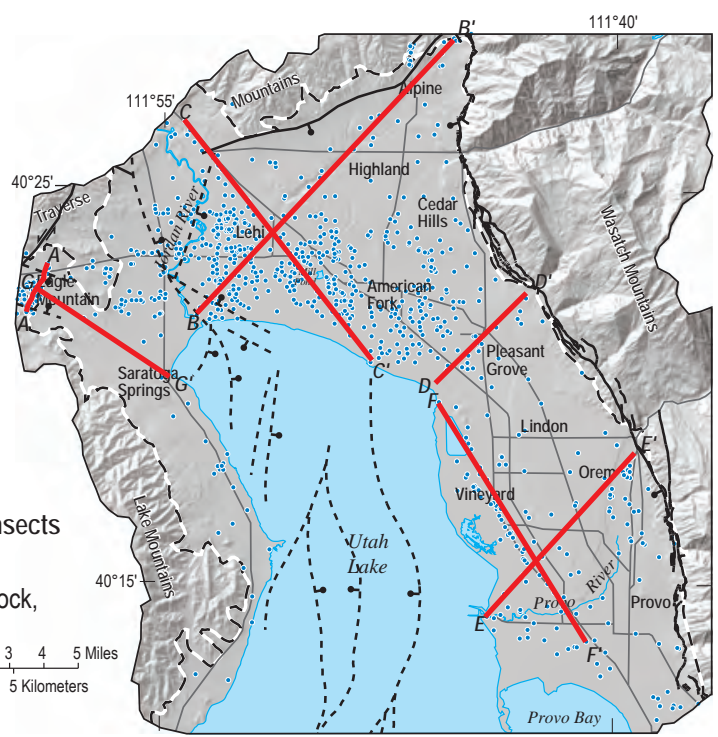

Figure 16. Cross section representing the hydrostratigraphic framework along West Canyon Creek from Cedar Pass to Utah Lake at Saratoga Springs (G-G'), northern Utah Valley, Utah. 


\section{Sources of Water to the Principal Basin-Fill Aquifer}

Water in the principal basin-fill aquifer occurs predominantly from two sources, including 1) seepage through the basin-fill sediments from surficial sources including streams and canals, irrigation water, domestic watering of lawns and gardens, and direct precipitation; and 2) as subsurface inflow from the adjacent mountain blocks. Contributions to the principal basin-fill aquifer from both sources were estimated to be 153,000 (+/- 31,500) acre-ft/yr during 1975-2004 (table 4) with surficial sources contributing 79,550 (+/- 11,100) acre-ft and mountain-block subsurface inflow (MBI) contributing 73,500 (+/- 22,500) acre-ft, including subsurface inflow from Cedar Valley. Infiltration from stream and canal seepage or "mountain-front recharge" was the greatest source of surfacewater recharge $(68,700$ +/- 9,500 acre-ft/yr) for 1975-2004.

Recharge of water from surficial sources to the principal basin-fill aquifer occurs predominantly near the mountain front within the primary recharge area of the valley where confining layers are thin and discontinuous (figs. 2 and 3). Subsurface inflow occurs where water in the mountain block flows into the basin-fill aquifer at the subsurface contact between the mountain block and basin-fill material. Heterogeneity and preferential flowpaths (faults and fractures) within each of the aquifers and at the contact between aquifers is a likely control on where inflow to the basin-fill aquifer occurs. Leakage to the confined basin-fill aquifers from the overlying unconfined LB aquifer within the secondary recharge area may occur but is considered negligible because of a relatively low amount of streamflow crossing the area and impermeable properties of the confining units. Recharge to the principal basin-fill aquifer as a result of seepage from septic systems was considered negligible and was not calculated because municipal sewer utilities are used in most of the developed areas within the primary recharge area.

Table 4. Sources of water and discharge as it relates to the ground-water hydrologic budget for the principal basin-fill aquifer in northern Utah Valley, Utah, 1975-2004.

[All values in acre-feet per year. Abbreviations: -, no data or value not calculated; \pm , plus or minus]

\begin{tabular}{|c|c|c|c|c|}
\hline Sources of water and discharge & $\begin{array}{c}\text { 1975-2004 } \\
\text { Annual average } \\
\text { (estimated error) }\end{array}$ & 2003-2004 & $\begin{array}{c}\text { 1980-82 } \\
\text { (Clark and } \\
\text { Appel, 1985) }\end{array}$ & $\begin{array}{c}\text { 1948-63 } \\
\text { (Cordova and } \\
\text { Subitsky, 1965) }\end{array}$ \\
\hline \multicolumn{5}{|c|}{ Sources of water } \\
\hline Stream and canal seepage & ${ }^{1} 68,700( \pm 6,900)$ & ${ }^{1} 56,500$ & 73,000 & 84,000 \\
\hline Irrigated fields & ${ }^{2} 4,800( \pm 500)$ & ${ }^{1} 1,400$ & 8,000 & $3,758,000$ \\
\hline Domestic watering (lawns and gardens) & ${ }^{2} 3,100( \pm 300)$ & 14,200 & 2,000 & - \\
\hline Subsurface inflow from the mountain block & ${ }^{1} 66,000( \pm 20,000)$ & ${ }^{1} 56,000$ & 112,000 & - \\
\hline Subsurface inflow from Cedar Valley & $7,500( \pm 2,500)$ & - & - & - \\
\hline Total (rounded) & $\begin{array}{c}153,000( \pm 31,500) \\
(122,000-185,000)\end{array}$ & - & ${ }^{5} 200,000$ & ${ }^{5,7} 150,000$ \\
\hline \multicolumn{5}{|c|}{ Discharge source } \\
\hline Springs and diffuse seepage beneath Utah Lake & $125,500( \pm 6,000)$ & ${ }^{1} 20,400$ & 37,000 & 30,000 \\
\hline Ground-water seepage to Jordan River & ${ }^{13}, 100( \pm 700)$ & ${ }^{1} 2,500$ & $3,500-5,600$ & 7,000 \\
\hline Evapotranspiration from ground water & $15,500( \pm 1,500)$ & ${ }^{1} 4,400$ & 8,000 & 13,000 \\
\hline Subsurface outflow to Salt Lake Valley & ${ }^{12}, 600( \pm 800)$ & - & 2,000 & - \\
\hline Total (rounded) & $\begin{array}{c}166,700( \pm 25,900) \\
(141,000-192,000)\end{array}$ & - & ${ }^{6} 220,000$ & $\begin{array}{l}5,7282,000 \\
(153,000)\end{array}$ \\
\hline
\end{tabular}

${ }^{1}$ Calculated using measured or estimated annual values.

${ }^{2}$ Calculated as the average of the 2003-04 calculated value and published value in Clark and Appel (1985) and Cordova and Subitsky (1965) where available.

${ }^{3}$ Calculation includes recharge from irrigated fields throughout all of northern Utah Valley not just within the primary recharge area.

${ }^{4}$ Cordova and Subitsky (1965) calculated the total discharge from waterways, drains, and springs including discharge from the shallow unconfined aquifer;

53,000 acre-feet is the estimated discharge from the principal basin-fill aquifer.

${ }^{5}$ Sum does not include all hydrologic components.

${ }^{6}$ Sum assumes average ground-water seepage to Jordan River is 4,500 acre-feet per year.

${ }^{7}$ Value includes contribution of recharge or discharge from the shallow unconfined aquifer; value in parenthesis is the estimated value for the principal basinfill aquifer only. 


\section{Stream and Canal Seepage}

Seepage of surface water from natural stream channels and large canals into the unconsolidated basin-fill deposits is estimated to be 56,500 acre-ft/yr during 2003-04 with an average of 68,700 acre-ft/yr during 1975-2004 (table 5). High infiltration rates occur along the mountain front where mountain streams and diverted canals flow into the valley and onto highly permeable coarse-grained basin-fill sediments (fig. 3). Eight major perennial streams flow into northern Utah Valley from the Wasatch Mountains including the Provo River, American Fork River, Dry Creek, Fort Creek, Battle Creek, Grove Creek, Rock Creek, and Slate Creek (fig. 1). One perennial stream, West Canyon Creek, originates west of the study area in the Oquirrh Mountains. This stream has a natural channel through Cedar Valley and into northern Utah Valley, but as a result of diversions at the canyon mouth and infiltration into the basin-fill deposits in Cedar Valley, the stream generally is dewatered before entering the study area. Cumulatively, the perennial streams discharge about 285,700 acre-ft to northern Utah Valley annually (1975-2004) (table 6). In addition to the perennial streamflow, three major diversions (Salt Lake Aqueduct, Olmsted Diversion/Alpine and Jordan Aqueducts, and Murdock Diversion/Provo Reservoir Canal) divert about 135,700 acre-ft/yr from the Provo River before the river enters the study area (table 7). The diverted water is delivered to northern Utah Valley and Salt Lake Valley for municipal and agricultural use. Annual gaged or estimated streamflow during 1975-2004 for streams in the study area is tabulated in table 6.

\section{Provo River, Major Diversions, and Valley Irrigation Canals}

The Provo River drainage basin, with an area of 637 $\mathrm{mi}^{2}$ and headwaters located outside of the study area in the Uinta Mountains, is the largest basin in northern Utah Valley. Average annual recharge to the principal basin-fill aquifer from streamflow seepage in the Provo River drainage basin is estimated to be 39,400 acre-ft/yr. Seepage from the Provo River below the valley canal diversions was estimated to be about 30,000 acre-ft/yr based on a seepage study completed by the Bureau of Reclamation and described by Clark and Appel (1985, p. 22). Seepage from the Provo River irrigation canals in the valley and the Provo Reservoir Canal is estimated to be 3,600 acre-ft/yr, and 5,900 acre-ft/yr, respectively (table 8).

Annual streamflow in the Provo River drainage basin is about 335,000 acre-ft with 285,000 acre-ft coming from within the Provo River Basin and 50,000 acre-ft from trans-basin water transfers from the Duchesne River via the Duchesne Tunnel in the Colorado River Basin and from the Weber River via the Weber-Provo Diversion in the Weber River Basin (table 7) (Utah Division of Water Rights, 2006). Major diversions from the Provo River in Provo Canyon, above the mountain block/basin-fill boundary and as far upstream as Deer Creek Reservoir, divert an average of about 136,000 acre-ft/yr of water out of the river for municipal and agricultural distribu-

Table 5. Sources of water to the principal basin-fill aquifer in northern Utah Valley, Utah, 1975-2004.

[All values in acre-feet per year. Bold value indicates totals. A bbreviations: \pm , plus or minus; - , not calculated due to lack of available data]

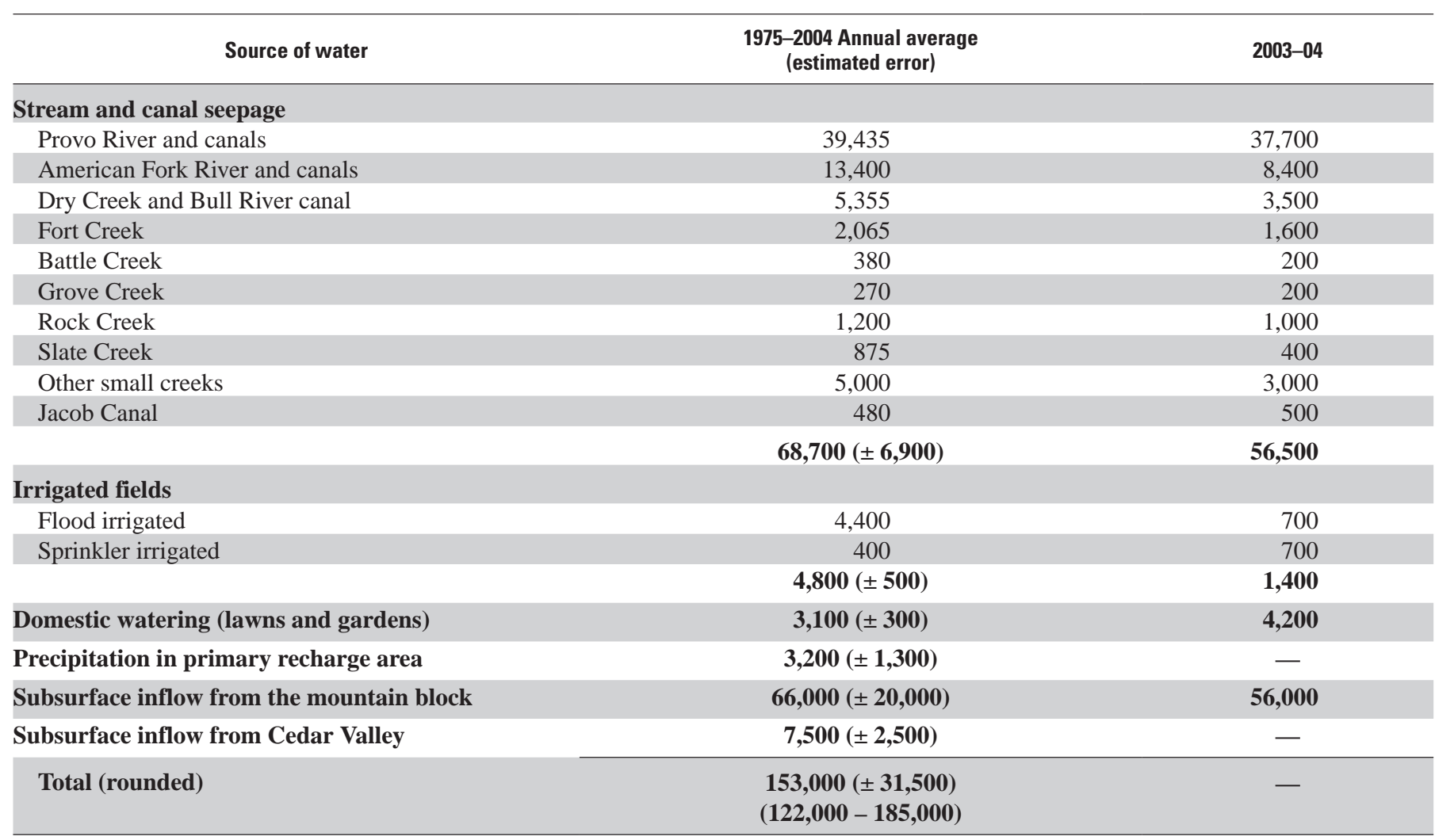




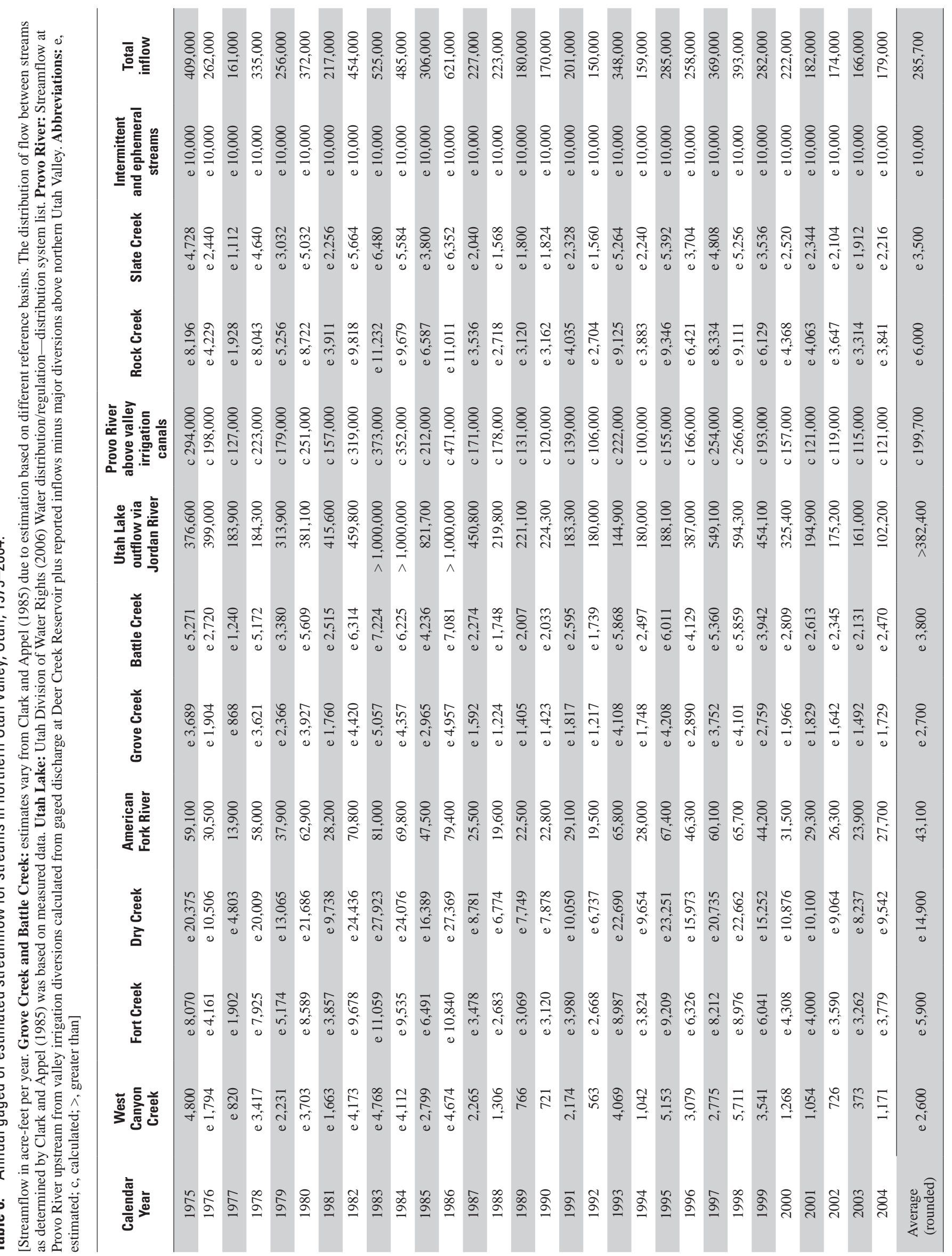


Table 7. Mean annual flow for trans-basin transfers and major diversions within the Provo River Basin, Utah County, Utah, $1975-2004$. [Calculated as acre-feet per year from measured discharge. OImsted Diversion structure first put into operation in 1988, average applies to 1989-2004 data. Abbreviations: e, estimate; - , no data]

\begin{tabular}{|c|c|c|c|c|c|c|}
\hline \multirow{2}{*}{$\begin{array}{l}\text { Calendar } \\
\text { year }\end{array}$} & \multicolumn{2}{|c|}{ Trans-basin transfers into the Provo River } & \multicolumn{3}{|c|}{$\begin{array}{l}\text { Major diversions out of the Provo River } \\
\text { above northern Utah Valley }\end{array}$} & \multirow{2}{*}{$\begin{array}{l}\text { Sum of major } \\
\text { diversions out of the } \\
\text { Provo River above } \\
\text { northern Utah Valley }\end{array}$} \\
\hline & Duchesne Tunnel & Weber-Provo Diversion & $\begin{array}{l}\text { Salt Lake } \\
\text { Aqueduct }\end{array}$ & $\begin{array}{l}\text { Olmsted Diversion/ } \\
\text { Alpine and Jordan } \\
\text { Aqueducts }\end{array}$ & $\begin{array}{l}\text { Murdock Diversion/ } \\
\text { Provo Reservoir Canal }\end{array}$ & \\
\hline 1975 & 17,200 & 58,700 & 17,100 & - & 100,500 & 117,600 \\
\hline 1976 & 16,300 & 36,900 & 31,400 & - & 86,700 & 118,100 \\
\hline 1979 & 32,800 & 30,100 & 46,700 & - & 77,200 & 123,900 \\
\hline 1980 & 15,400 & 22,800 & 43,500 & - & 94,500 & 138,000 \\
\hline 1981 & 18,000 & 28,200 & 43,700 & - & 75,500 & 119,200 \\
\hline 1982 & 13,000 & 22,700 & 28,400 & - & 96,900 & 125,300 \\
\hline 1983 & 1,000 & 13,200 & 30,900 & - & 74,300 & 105,200 \\
\hline 1988 & 25,800 & 11,900 & 52,600 & - & 37,700 & 90,300 \\
\hline 1989 & 24,900 & 17,900 & 38,900 & 47,000 & 47,600 & 133,500 \\
\hline 1990 & 800 & 300 & 39,600 & 73,400 & e 42,000 & 155,000 \\
\hline 1991 & 21,800 & 19,000 & 38,600 & 61,200 & 35,600 & 135,400 \\
\hline 1992 & 1,900 & 12,900 & 41,000 & 67,400 & 2,100 & 110,500 \\
\hline 1993 & 37,500 & 68,100 & 41,700 & 50,100 & 72,300 & 164,100 \\
\hline 1994 & 22,900 & 38,600 & 43,100 & 64,600 & 46,600 & 154,300 \\
\hline 1995 & 39,400 & 47,900 & 53,100 & 48,200 & 63,600 & 164,900 \\
\hline 1996 & 31,600 & 50,400 & 54,400 & 58,100 & 81,800 & 194,300 \\
\hline 1997 & 40,900 & 13,900 & 38,700 & 58,600 & 92,000 & 189,300 \\
\hline 1998 & 33,200 & 31,200 & 48,200 & 63,200 & 67,700 & 179,100 \\
\hline 1999 & 32,200 & 41,700 & 50,800 & 68,000 & 77,300 & 196,100 \\
\hline
\end{tabular}

tion within northern Utah Valley and Salt Lake Valley (table 7). The remaining 200,000 acre-ft/yr (table 6) in the Provo River enters northern Utah Valley where it is used for irrigation supply through a network of irrigation canals diverted at the canyon mouth, as instream flows within the Provo River leading to Utah Lake, and as ground-water recharge to the basin-fill aquifers.

Annual streamflow for the Provo River above the valley irrigation diversions (table 6) was calculated using flow data from USGS streamflow-gaging station 10159500 (Provo River below Deer Creek Reservoir) plus estimated inflow from four minor drainage basins between Deer Creek Reservoir and the mouth of the canyon including Provo-Deer Creek, North Fork Provo Creek, South Fork Provo Creek, and Pole Canyon Creek. Historical USGS streamflow data were used to estimate annual streamflow to be 10,000, 15,000, and 25,000 acre-ft/yr for Provo-Deer Creek, North Fork Provo Creek, and South Fork Provo Creek, respectively. Historical data were not available for Pole Canyon Creek; therefore, an annual streamflow estimate was established by correlating the basin area and annual precipitation relative to the basin area and annual precipitation of the gaged American Fork River Basin (table 9). Basin area was calculated by using the basin hydrologic unit code (HUC) (Seaber and others, 1987) area above the basin-fill/mountain-block boundary (approximated at the canyon mouth). Annual precipitation was calculated by using PRISM precipitation data within each HUC. Average annual streamflow for Pole Canyon Creek was estimated to be 10,000 acre-ft/yr with the equation: 
Table 8. Average annual flow and seepage loss for streams and major canals in northern Utah Valley, Utah, $1975-2004$.

[Bold values indicate sum. Abbreviations: acre-ft/yr, acre-feet per year; e, estimated; —, no data or not applicable]

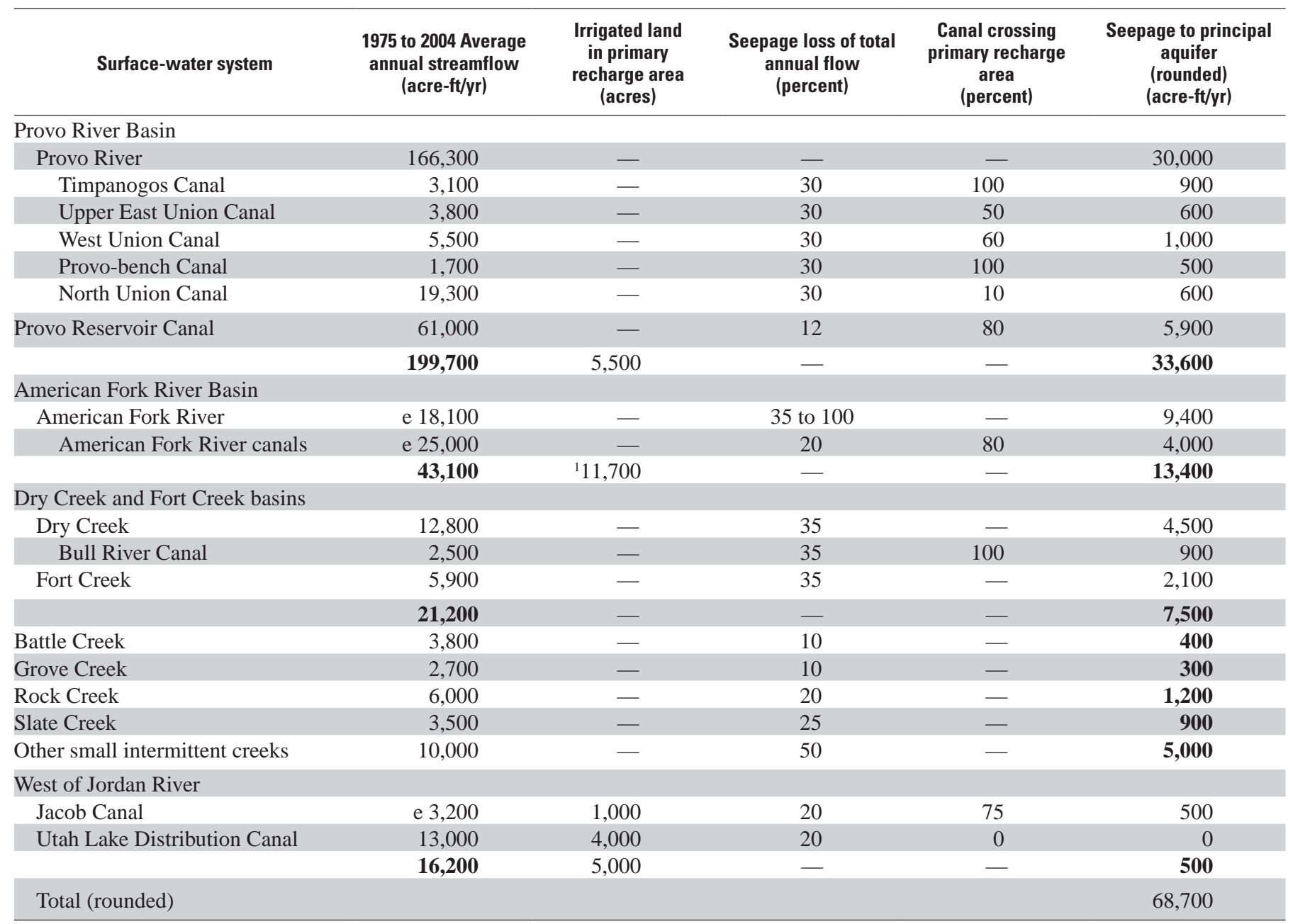

${ }^{1}$ Includes irrigated land for both Dry Creek and Fort Creek basins.

$$
\mathrm{Q}_{\text {drainage }}=\mathrm{cf} 1_{\text {size }} \times \mathrm{cf} 2_{\text {prec }} \times \mathrm{Q}_{A F}
$$

where

$$
\begin{gathered}
\mathrm{Q}_{\text {drainage }} \text { is the discharge of ungaged stream, in acre-ft/ } \\
\mathrm{yr}, \\
\mathrm{cf} 1_{\text {size }} \text { is the ratio of the ungaged stream basin area } \\
\text { to the American Fork Basin area, } \\
\mathrm{cf} 2_{\text {prec }} \text { is the ratio of annual precipitation in the } \\
\text { ungaged stream basin to the annual } \\
\text { precipitation in the American Fork Basin, }
\end{gathered}
$$

and

$$
\begin{gathered}
\mathrm{Q}_{A F} \text { is gaged discharge of the American Fork } \\
\text { River, in acre-ft/yr. }
\end{gathered}
$$

The 22-mi long Provo Reservoir Canal diverts water from the Provo River above the mouth of the canyon and transports it north through northern Utah Valley to the Jordan Narrows for use as irrigation and municipal supply in both northern Utah and Salt Lake Valleys. Annual losses resulting from seepage were estimated to be 5,900 acre-ft (table 8) based on an average (1975 to 2004) annual flow of 61,000 acre-ft and an average seepage loss rate of 12 percent as calculated by Clark and Appel (1985, table 6) for flows measured during 1972-79. Seepage was decreased by 80 percent to account for the percentage of the mostly unlined canal crossing the primary recharge area.

Two other major canals/pipelines, the Salt Lake Aqueduct and the Jordan Aqueduct, divert water from the Provo River above the canyon mouth, traverse the valley along the mountain front, and distribute water to northern Utah Valley and Salt Lake Valley for municipal and agricultural uses. The Salt Lake Aqueduct and the Jordan Aqueduct are lined or piped throughout the study area and seepage is considered negligible.

Five canals branching from the Provo River below the canyon mouth (fig. 2) contributed 3,600 acre-ft/yr as seepage to the principal basin-fill aquifer (table 8) within the primary recharge area. Seepage loss from canals was estimated to average 30 percent of the average (1975-2004) annual canal flow, based on seepage estimates of 25 to 35 percent reported by Clark and Appel (1985, table 7). The calculated seepage loss is 
Table 9. Ratio of drainage-basin area and annual precipitation in ungaged basins relative to the gaged American Fork River basin, northern Utah Valley, Utah.

\begin{tabular}{lcc}
\hline \multicolumn{1}{c}{ Ungaged drainage basin } & Basin area & $\begin{array}{c}\text { Annual } \\
\text { precipitation }\end{array}$ \\
\hline $\begin{array}{l}\text { Battle Creek and Grove Creek } \\
\text { (combined) }\end{array}$ & 0.182 & 0.833 \\
$\begin{array}{l}\text { Rock Creek } \\
\text { Slate Creek }\end{array}$ & .162 & .856 \\
Pole Canyon Creek & .100 & .800 \\
\hline
\end{tabular}

reduced to represent the percentage of the total length of each canal crossing the primary recharge area.

\section{American Fork River}

Average annual recharge (1975-2004), as seepage losses from the American Fork River and its associated canals, was estimated to be 13,400 acre-ft (tables 5 and 8). Seepage loss through the American Fork River streambed was calculated to average 9,400 acre-ft/yr (table 8 ) with a minimum value of 4,100 acre-ft in 1977 and a maximum value of 19,400 acre-ft during 1983 based on findings from seepage studies done in 1981-82 (Clark and Appel, 1985, p. 22). These studies determined that losses from the American Fork River across the primary recharge area ranged from 100 percent of the streamflow when flow was less than $20 \mathrm{ft}^{3} / \mathrm{s}$ to losses of 35 percent when streamflow exceeded $200 \mathrm{ft}^{3} / \mathrm{s}$. Streamflow losses were interpolated linearly from 100 percent loss to 35 percent loss for streamflow between 20 and $200 \mathrm{ft}^{3} / \mathrm{s}$, respectively. Streamflow records for the unregulated section of the American Fork River above the upper power plant, in American Fork Canyon (USGS streamflow-gaging station 10164500) have been reported from 1927 to 2004. The American Fork River drainage basin is the second largest in the study area $\left(51.1 \mathrm{mi}^{2}\right)$ and includes drainage from the highest altitudes within the study area. Average annual streamflow (1975-2004) for the American Fork River is 43,100 acre-ft/yr (table 8). Average monthly streamflow for the American Fork River is greatest during the period of snowmelt runoff with a 30-year average of about 60 $\mathrm{ft}^{3} / \mathrm{s}$ (fig. 17).

Daily streamflow in the American Fork River at USGS streamflow-gaging station 10164500 was used to estimate streamflow below irrigation canal diversions at the mouth of the canyon. Seepage to the basin-fill deposits from streamflow in the American Fork River channel was adjusted to account for canal diversions assuming that all streamflow less than 200 $\mathrm{ft}^{3} / \mathrm{s}$ is diverted into canals during the irrigation season from April 15 to October 15. Streamflow exceeding $200 \mathrm{ft}^{3} / \mathrm{s}$ during the irrigation season and all streamflow during the remainder of the year is assumed to be available as seepage within the natural stream channel.

Annual seepage loss from canals originating along the American Fork River was calculated to average 4,000 acre-ft, with a minimum of 1,600 acre-ft in 1977 and a maximum of 7,700 acre-ft in 1983. Canal flow was calculated using the same assumptions for the stream, as listed above. A seepage loss rate of 20 percent (Clark and Appel, 1985, p. 22) was used for about $9.5 \mathrm{mi}$ of mostly unlined canals traversing the primary recharge area.

For this study, the American Fork River is assumed to be representative of streams in other basins within the study area; therefore, its long-term streamflow record was correlated to streamflow in basins having a shorter period of record or no streamflow record. Fort Creek, Dry Creek, and West Canyon Creek have at least some period of streamflow record, 8 years (1948-55), 8 years (1948-55), and 30 years (1965-75 and 1986-2004), respectively. A linear correlation was established for each of these streams to annual gaged streamflow in the American Fork River based on respective periods of streamflow record (fig. 18), and streamflow was estimated by using the regression equations shown in figure 18 .

\section{Dry Creek}

Average annual recharge for 1975-2004 to the principal basin-fill aquifer from seepage losses in Dry Creek and the Bull River Canal was estimated to be 5,400 acre-ft (tables 5 and 8), with a minimum of about 1,700 acre-ft in 1977 and a maximum of about 10,000 acre-ft in 1983. Seepage was calculated by using a seepage rate of 35 percent of the estimated annual streamflow in Dry Creek based on seepage loss percentages for the adjacent American Fork River.

\section{Fort Creek}

Average annual recharge from Fort Creek is estimated to be 2,100 acre-ft (table 8) based on a seepage loss of 35-percent of the 1975-2004 average annual estimated flow of 5,900 acre-ft (table 6). Clark and Appel (1985) estimated seepage loss to be 20 and 50 percent during peak and base flow, respectively. This study estimated streamflow on an annual basis and could not apply a variable seepage rate; therefore, 35 percent was used as an average. Clark and Appel (1985, p. 26) note that about two-thirds of the seepage losses were in the natural channel and the remainder occurred in canals.

\section{Other Small Streams, Minor Drainage Basins, and Canals}

Average annual recharge to the principal basin-fill aquifer occurring as seepage loss from small mountain streams (Battle Creek, Grove Creek, Rock Creek, and Slate Creek), minor intermittently flowing streams, and the Jacob Canal on the west side of the valley is estimated to be 8,200 acre- $\mathrm{ft}$ for the period 1975-2004 (table 8). Recharge as seepage from the small mountain streams generally only occurs during annual high flows when water remains in the natural stream channel and is not completely diverted into irrigation canals. Seepage loss from the Jacob Canal occurs during the irrigation season when the canal is in use. Seepage losses from the streams and canal were calculated by estimating annual flows for each stream during 1975 to 2004 (table 6) and applying seepage loss percentages of 10 to 50 percent of the flow, as estimated for each stream by Clark and Appel (1985, p. 29). 


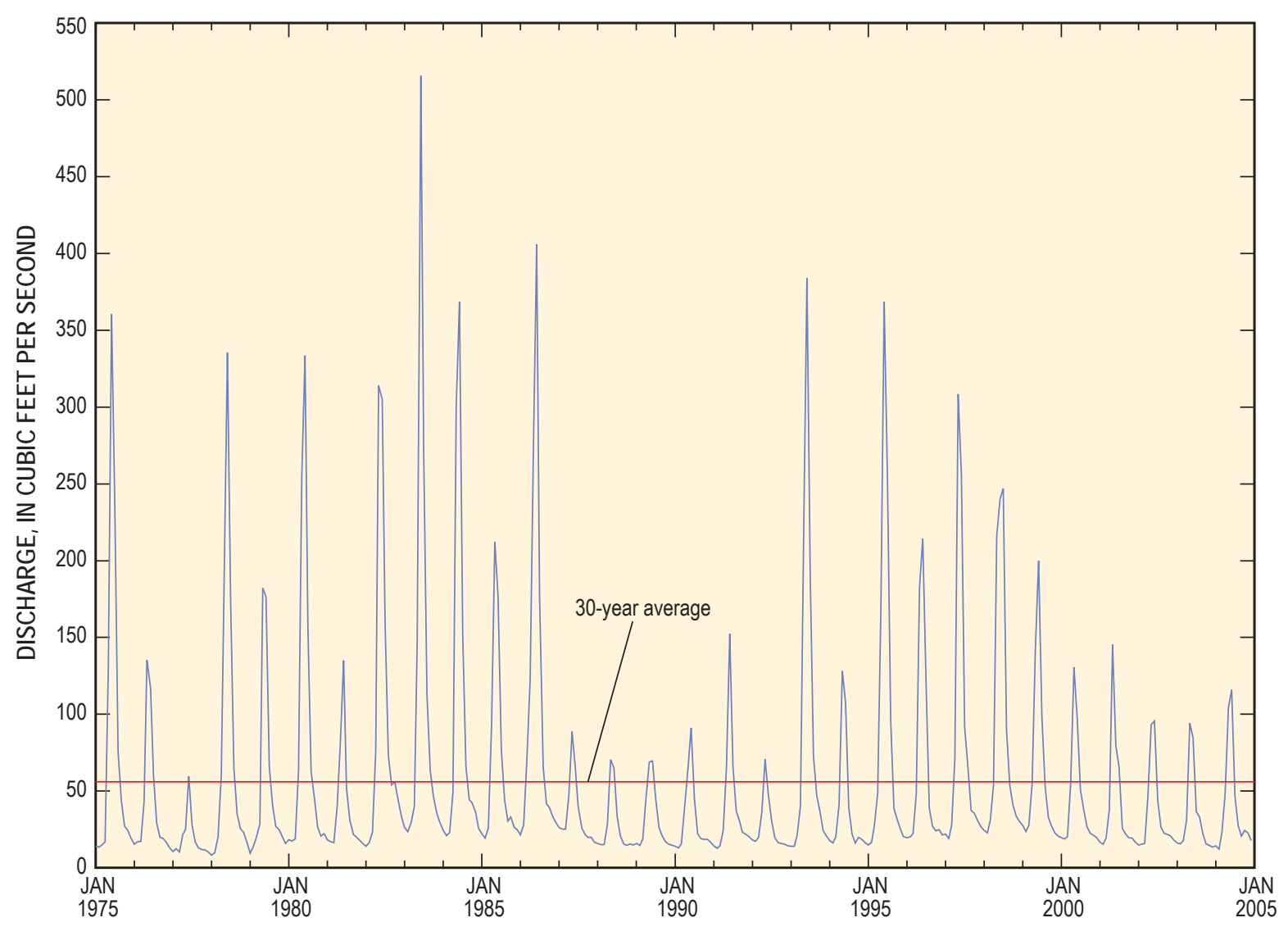

Figure 17. Average monthly streamflow of the American Fork River above the upper power plant in American Fork Canyon, Utah County, Utah, 1975-2005.

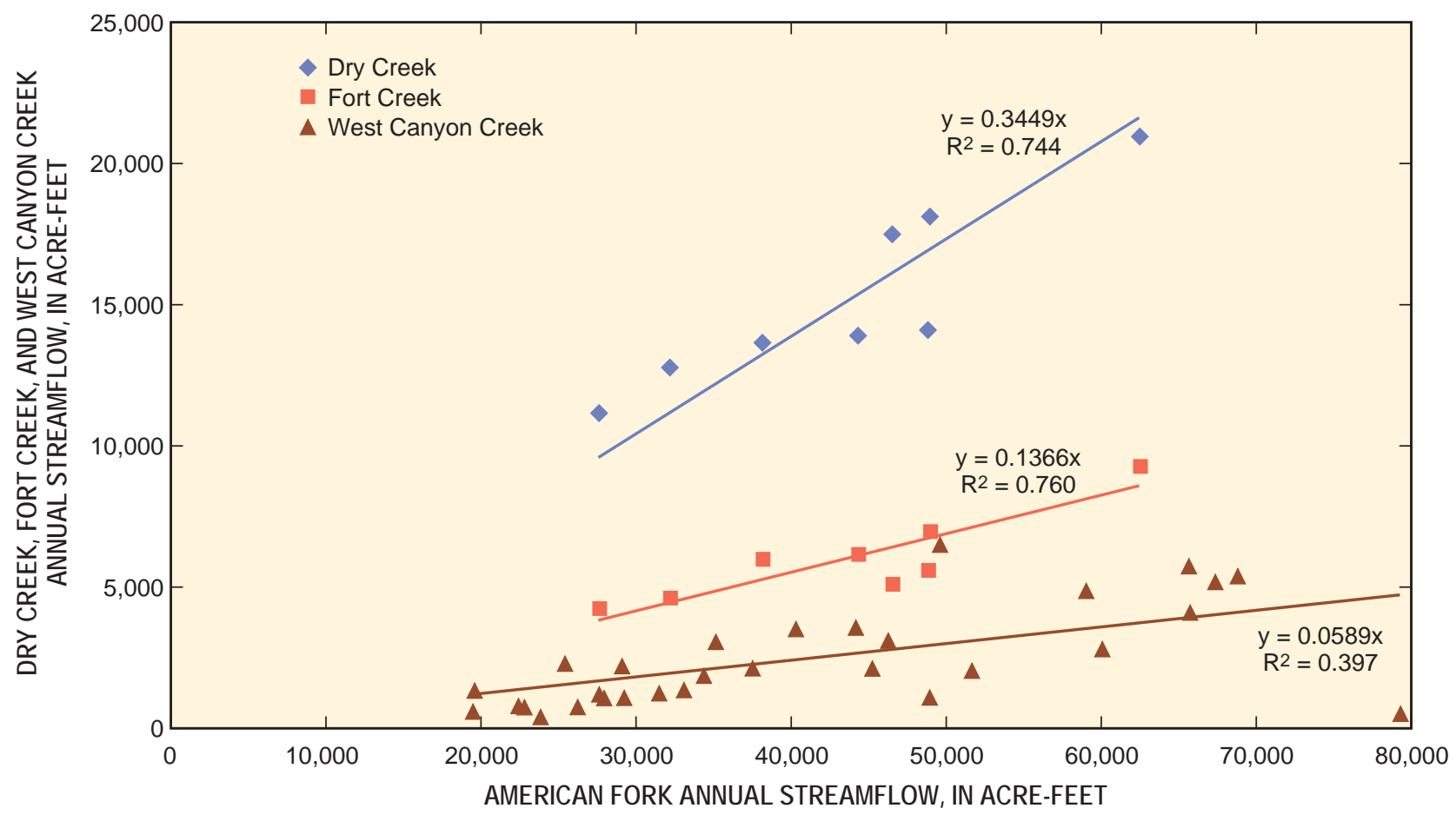

Figure 18. Correlation of streamflow for Dry Creek, Fort Creek, and West Canyon Creek to the American Fork River, northern Utah Valley study area, Utah. 
Grove Creek, Battle Creek, Rock Creek, and Slate Creek do not have streamflow records. Annual streamflow estimates for these streams were estimated by using ratios of basin area and annual precipitation to the basin area and annual precipitation of the American Fork River basin (table 9) and equation 1. Total streamflow for Grove and Battle Creeks was distributed between the two creeks so that Grove Creek was 70 percent of the flow in Battle Creek, as established by Clark and Appel (1985, p. 16) from measurements made during 1968-70. Seepage loss from Grove Creek and Battle Creek was estimated by Clark and Appel $(1985$, p. 29) to be 10 percent of the annual streamflow, resulting in seepage to the principal basin-fill aquifer of 400 and 300 acre-ft/yr, respectively. Rock Creek loses an estimated 20 percent (1,200 acre-ft) (Clark and Appel, 1985 , p. 29) of its annual flow of 6,000 acre-ft through both the natural channel and small irrigation ditches. Slate Creek loses an estimated 25 percent (900 acre-ft) (Clark and Appel, 1985, p. 29) of its estimated annual flow of 3,500 acre-ft.

Intermittent and ephemeral streamflow within small drainage basins along the mountain fronts throughout the study area were estimated by Clark and Appel (1985, p. 16) to be about 10,000 acre-ft/yr. The estimate is based on the relation between area of the drainage basin, mean annual precipitation, and long-term streamflow records for 12 streams along the Wasatch Front from Ogden to Provo. Seepage from intermittent and ephemeral streams was estimated to be 50 percent (Clark and Appel, 1985, p. 29), or about 5,000 acre-ft of the estimated annual streamflow. This estimate includes tributary inflow to the American Fork River downstream from the gaging station that is not accounted for in the seepage estimate from the American Fork River and its canals.

Recharge to the basin-fill aquifers as seepage loss from Jacob Canal, which distributes irrigation water to land west of the Jordan River, is estimated to be 500 acre-ft/yr. Flow records for the Jacob Canal were not available; therefore, flows were estimated to be about 25 percent of flow in the south arm of the Utah Lake Distribution Canal that also delivers irrigation water to land west of the Jordan River but not within the primary recharge area. The Utah Lake Distribution Canal has a water right of 15,500 acre-ft/yr but rarely flows at capacity (Scott Holbrook, Utah Lake Distribution Canal Co., oral commun., 2006), therefore the value is considered a maximum. Assuming an average consumptive use of $2.1 \mathrm{ft} / \mathrm{yr}$ for irrigated crops and a 20-percent loss as a result of seepage and evaporation, the minimum flow required to sustain crops supplied by the Utah Lake Distribution Canal is estimated to be 10,600 acre-ft/yr. The average of these two values, 13,000 acre- $\mathrm{ft} / \mathrm{yr}$, is reported here. The area of irrigated land serviced by the Jacob Canal is 1,000 acres or 25 percent of the land serviced by the south arm of the Utah Lake Distribution Canal. By using the same assumptions as for the Utah Lake Distribution Canal and a 25-percent reduction in serviceable land, the annual flow in Jacob Canal is estimated to be 3,200 acre-ft. If an average seepage loss of 20 percent for unlined canals is assumed, Jacob Canal could lose 640 acre-ft/yr. About 75 percent of Jacob Canal is located in the primary recharge area; therefore, 500 acre-ft/yr would recharge the principal basin-fill aquifer.

\section{Direct Infiltration of Precipitation on Basin-Fill Sediments}

Recharge to the principal basin-fill aquifer in the primary recharge area (fig. 2) as direct infiltration of precipitation is estimated to average 3,200 acre-ft/yr for 1975-2004 (table 5). By using 1971-2000 PRISM precipitation data, the average annual rainfall volume was calculated to be 45,000 acre-ft. Two methods, including Anderson and others (1992) and Brooks and Stolp (1995), were used to evaluate the fraction of precipitation that recharges the principal aquifer.

Brooks and Stolp (1995, p. 19) estimated that recharge as direct infiltration to the basin-fill aquifers in southern Utah Valley ranges from 5 to 10 percent of direct precipitation over the valley. The percentage depends on multiple factors, including distance to the mountain front, irrigated or nonirrigated land use, and consumptive use of precipitation and applied water in irrigated areas. Recharge in irrigated areas of northern Utah Valley was estimated to be 7 percent of the total applied water and precipitation combined. Land use over the primary recharge area in northern Utah Valley is predominantly developed as irrigated agriculture or for commercial and residential purposes with the exception of a small band east of the Lake Mountains that is classified as having nonirrigated crops. Applying 7 percent as the fraction of precipitation recharging the principal aquifer in northern Utah Valley annually results in an estimated recharge of 3,200 acre-ft (table 5).

The regression equation of Anderson and others (1992) compares estimated recharge from the Maxey-Eakin model (Maxey and Eakin, 1950) to average annual precipitation contours from PRISM data for basins throughout the Great Basin where precipitation rates exceed $8 \mathrm{in} / \mathrm{yr}$. The method calculates a higher percentage of recharge where precipitation rates are higher. The equation developed is as follows:

$$
\mathrm{Q}_{\text {infiltration }}=10^{\left(-1.4+0.98 \times \operatorname{LOG}\left(\mathrm{Q}_{\text {precipitation }}\right)\right)}
$$

where

$\mathrm{Q}_{\text {infiltration }}$ is the rate of infiltration of precipitation, in acre-ft/yr,

and

$\mathrm{Q}_{\text {precipitation }}$ is the volume of precipitation, in acre- $\mathrm{ft} / \mathrm{yr}$.

Using the above equation and an average annual precipitation volume over the primary recharge area, recharge from direct precipitation in the primary recharge area was calculated to be 1,400 acre-ft/yr and is considered a minimum value for northern Utah Valley because the method was developed for a regional area in Utah and Nevada. Clark and Appel (1985, p. 31) calculated recharge to be 5,000 acre-ft/yr based on an average recharge rate of 20 percent of the 1963-81 average annual precipitation over the primary recharge area. 


\section{Seepage of Irrigation Water}

Recharge to the principal aquifer from seepage of unconsumed irrigation water in the primary recharge area for 2003-04 is estimated to be 1,400 acre-ft/yr for both flood irrigation (700 acre-ft/yr) and sprinkler irrigation (700 acre-ft/yr). An average value of 4,800 acre-ft/yr is estimated for seepage from irrigated fields during 1975-2004 (table 5). Clark and Appel (1985, p. 29) reported recharge to the principal aquifer from seepage of irrigation water for 5,000 acres in the primary recharge area to be 8,000 acre-ft/yr, as compared to the 1,400 acre-ft/yr reported here. The lower estimate reported in this study is attributed to a decrease in irrigated lands caused by urbanization and a change from flood irrigation to more efficient sprinkler irrigation practices. Sources of irrigation water are primarily surface-water diversions from the major streams with a supplemental supply from irrigation wells. Seepage of unconsumed irrigation water is dependent upon many factors including the amount of irrigation water applied to crops, the type of irrigation method (flood, line sprinkler, or center pivot), the consumptive use of crops, and soil permeability. In 2002 , about 1,850 acres within the primary recharge area of northern Utah Valley were classified as flood-irrigated crops (550 acres) and sprinkler-irrigated crops (1,300 acres) (Utah Department of Natural Resources, 2004). These were the most recent land-use and irrigation data available and are assumed to be representative of the study period, 2003-04. The predominant irrigated crops in the primary recharge area include alfalfa, grains, irrigated pasture, and corn, which account for about 90 percent of all the crops grown. Consumptive uses for these crops generally range from 2 to $2.5 \mathrm{ft} / \mathrm{yr}$ (Huber and others, 1982).

Soils are generally very permeable throughout the primary recharge area, and seepage of unconsumed irrigation water is estimated to be about 33 percent of the applied water, as reported in Clark and Appel (1985, p. 29). This estimate is based on studies completed by the Bureau of Reclamation (1968 and 1969) in southern Utah Valley in an area with similar physical characteristics and irrigation practices. For flood-irrigated fields, it is assumed that about $4 \mathrm{ft} / \mathrm{yr}$ is applied to crops to satisfy crop consumptive use, losses to evaporation and runoff, and to allow for seepage. Using these assumptions along with 2002 land-use data it was calculated that about 700 acre-ft/yr of unconsumed irrigation water would be available as recharge to the principal aquifer in 2003-04.

Sprinkler irrigation has replaced flood irrigation in much of northern Utah Valley, where about 70 percent of the irrigated crops in the primary recharge area are irrigated with either line or center-pivot sprinkler methods. Seepage from line-sprinkler irrigation was calculated to be about 500 acre-ft/ yr for about 600 acres of crops mapped in 2002 in the primary recharge area. Seepage was estimated to be 30 percent of the applied irrigation water (Feltis, 1967, p. 17). The amount of irrigation water applied to the line-sprinkler irrigated fields is assumed to be about $3 \mathrm{ft} / \mathrm{yr}$ to satisfy both the consumptiveuse rate for the crops of $2.2 \mathrm{ft} / \mathrm{yr}$ and seepage losses. Seepage from center-pivot irrigation systems was calculated to be about 200 acre-ft/yr for about 700 acres of crops mapped in 2002 in the primary recharge area (predominantly east of the Jordan River). An average seepage loss of about 11 percent of the total applied irrigation water is assumed based on a study by Susong (1995, p. 27) in the Milford area in southwestern Utah. Total recharge from sprinkler irrigation to the basin-fill aquifer over the primary recharge area, therefore, is estimated to be about 700 acre-ft/yr.

\section{Seepage from Domestic Lawn and Garden Watering}

The average annual recharge to the principal basin-fill aquifer in the primary recharge area from seepage of domestic lawn and garden watering in 1975-2004 is calculated to be 3,100 acre-ft on the basis of estimates made from 1980 and 2002 land-use data (table 5). An area of about 11,200 acres in the primary recharge area was classified as commercial and residential land use in 2002 (Utah Department of Natural Resources, 2004). Analysis of aerial photography indicates that about 30 percent of land classified as commercial and residential land use in the primary recharge area consists of an irrigated area such as lawns and gardens. Jordan Valley Water Conservancy District (2005) estimates that the average homeowner in nearby southern Salt Lake Valley applies 50 in. $(4.2 \mathrm{ft}$ ) of water per year to residential lawns and gardens. Seepage from domestic lawn and garden watering is assumed to be 30 percent of the amount applied, as was used by Clark and Appel (1985, p. 31), resulting in about 4,200 acre-ft/yr of seepage for 2003-04 when calculated from 2002 land-use data.

Commercial and residential land use and the associated seepage from domestic lawn and garden watering in 2002 have increased by about 110 percent when compared to 1980 estimates. The increase in commercial and residential land use corresponds to a decrease in irrigated agricultural land and an associated decrease in seepage from unconsumed irrigation water. Estimated annual seepage from unconsumed irrigation water over the primary recharge area from 1980 to 2002 decreased by about 6,600 acre-ft (8,000 to 1,400 acre-ft), whereas seepage from domestic lawn and garden watering increased by about 2,200 acre-ft (2,000 to 4,200 acre-ft) over the same time period and area. This results in a net loss of recharge to the basin-fill aquifer of about 4,400 acre-ft/yr between 1980 and 2002 as a result of urbanization.

\section{Subsurface Inflow}

Subsurface inflow of water to the basin-fill deposits and principal aquifer in northern Utah Valley occurs from two primary sources including inflow from the surrounding mountain blocks and as interbasin flow from Cedar Valley, located west of northern Utah Valley. Subsurface inflow from both sources was estimated to average $73,500(+/-22,500)$ acre-ft/yr for 1975-2004, with 66,000 acre-ft/yr coming from the mountain 
blocks and 7,500 acre-ft/yr occurring as inflow from Cedar Valley.

\section{Mountain-Block Inflow}

Mountain-block subsurface inflow (MBI), to the principal basin-fill aquifer is estimated to average (1975-2004) about 66,000 acre-ft/yr in northern Utah Valley (table 5). Two methods were evaluated to estimate the net infiltration from precipitation in the mountains: a hydrologic budget of the mountain-block areas and a geographic information system (GIS)-based net-infiltration model, referred to as the Basin Characterization Model (BCM) (Flint and others, 2004). A portion of this net infiltration is returned to mountain streams and rivers, becoming stream base flow, and the remainder (net infiltration minus the base flow) is assumed to enter the principal basin-fill aquifer as subsurface inflow from the mountain block.

The hydrologic budget method was used to determine how much water, originating as precipitation, would be available as recharge within the mountain block (net infiltration) (table 10). The hydrologic budget is as follows:

$$
\mathrm{Q}_{\text {net_infl }}=\mathrm{Q}_{\text {precip }}-\mathrm{Q}_{\text {et }}-\mathrm{Q}_{\text {runoff }}
$$

where

$$
\begin{aligned}
& \mathrm{Q}_{\text {net_infl }} \text { is net infiltration, in acre-ft/yr, } \\
& \mathrm{Q}_{\text {precip }} \text { is estimated annual average precipitation, in } \\
& \text { acre- } \mathrm{ft} / \mathrm{yr} \text {, } \\
& \mathrm{Q}_{e t} \quad \text { is calculated annual evapotranspiration } \\
& \text { (consumptive use), in acre-ft/yr, }
\end{aligned}
$$

and

$$
\begin{aligned}
& \mathrm{Q}_{\text {runoff }} \text { is calculated annual average surface-water } \\
& \text { runoff, in acre-ft/yr. }
\end{aligned}
$$

Average annual precipitation throughout the mountain block was calculated to be 280,000 acre-ft (table 10) based on 1971-2000 PRISM precipitation data. Evapotranspiration or consumptive-use estimates within the mountain block for individual HUCs were derived using 2002 land-use land cover data (Utah Department of Natural Resources, 2004) in association with estimates of plant consumptive use as summarized by Brooks and others (2003, table 1) (table 11). Surface-water runoff was estimated by subtracting the estimated average annual stream base-flow contribution from the 1975-2004 average annual streamflow for each HUC within the mountain block. Base flow for streams with at least 4 years of record for streamflow was calculated by using mean monthly flows during the winter months of December, January, and February. The average flow during the winter months was extrapolated throughout the year, yielding an estimate for average annual base flow within each basin. For streams with no streamflow record, base flow was assumed to equal 25 percent of the total annual streamflow. This estimate is based on the ratio of base flow to total streamflow for gaged streams. Total average base flow for streams within the northern Utah Valley mountain block is estimated to be 25,000 acre-ft/yr (table 10). Average annual net infiltration to the mountain block, as calculated from equation 3, was estimated to be 92,000 acre-ft (table 10). Subtracting the base-flow component $(25,000$ acre-ft) from the net infiltration results in an estimated average of about 66,000 acre-ft/yr of subsurface inflow from the mountain block to the principal basin-fill aquifer, or about 24 percent of the total precipitation occurring over the mountain block.

The GIS-based net-infiltration BCM incorporates spatial estimates of precipitation (PRISM), temperature, potential evapotranspiration, bedrock geology, soil type and thickness, and vegetation type (Flint and others, 2004). The method also accounts for soil-moisture requirements and subsequent loss of soil moisture through evapotranspiration. After adjustments were made to the initial BCM, the average amount of net infiltration of precipitation within the mountain block calculated by this method was 68,500 acre-ft/yr (table 12). Removing base flow to streams $(25,200$ acre-ft/yr) from the estimate of net infiltration results in an average of 43,200 acre-ft/yr from mountain-block subsurface inflow.

An initial value for net infiltration in the Middle and Upper American Fork River Canyon HUCs that was determined from the model, 15,400 acre-ft/yr (table 12), accounted for only 13 percent of the total precipitation occurring within these HUCs. This value is low when compared to neighboring basins to the south with similar physical characteristics (precipitation, elevation, and geology) where 24 to 29 percent of precipitation becomes net infiltration. In addition, a net infiltration value of 37,100 acre-ft/yr, about 31 percent of precipitation, was calculated by using equation 3 to determine the hydrologic budget for Middle and Upper American Fork Canyon. The BCM net-infiltration value is believed to be low because the distribution of precipitation as recharge and runoff from the model is based partly on bedrock geology. The model can incorrectly distribute net infiltration in areas where extreme low and high values of bedrock permeability occur within a close proximity (Alan Flint, U.S. Geological Survey, oral commun., 2006). This condition exists in the Middle and Upper American Fork Canyon HUCs where less-permeable granodiorite underlies part of the upper drainage basin and permeable, fractured, porous limestone dominates the majority of the drainage basin. Because of the extreme contrast in bedrock permeability, modeled net infiltration is likely underestimated in these areas. On the basis of the BCM results for adjacent areas with similar fractured limestone geology and elevation, as well as from the simplified hydrologic budget analysis, net infiltration (as applied by the BCM) was increased for the middle and upper American Fork Canyon HUCs to equal 29 percent of precipitation (35,000 acre-ft/yr) within those HUCs.

Only 12 percent of the precipitation on the Headwaters Dry Creek HUC becomes net infiltration to the mountain block, based on the BCM. This amount was not enough to satisfy the base flow estimated to be discharged in the basin, resulting in a deficit of 1,900 acre-ft/yr. Subsurface inflow within the Headwaters Dry Creek HUC was adjusted to zero to partially meet the base-flow requirement. The parameter in the 


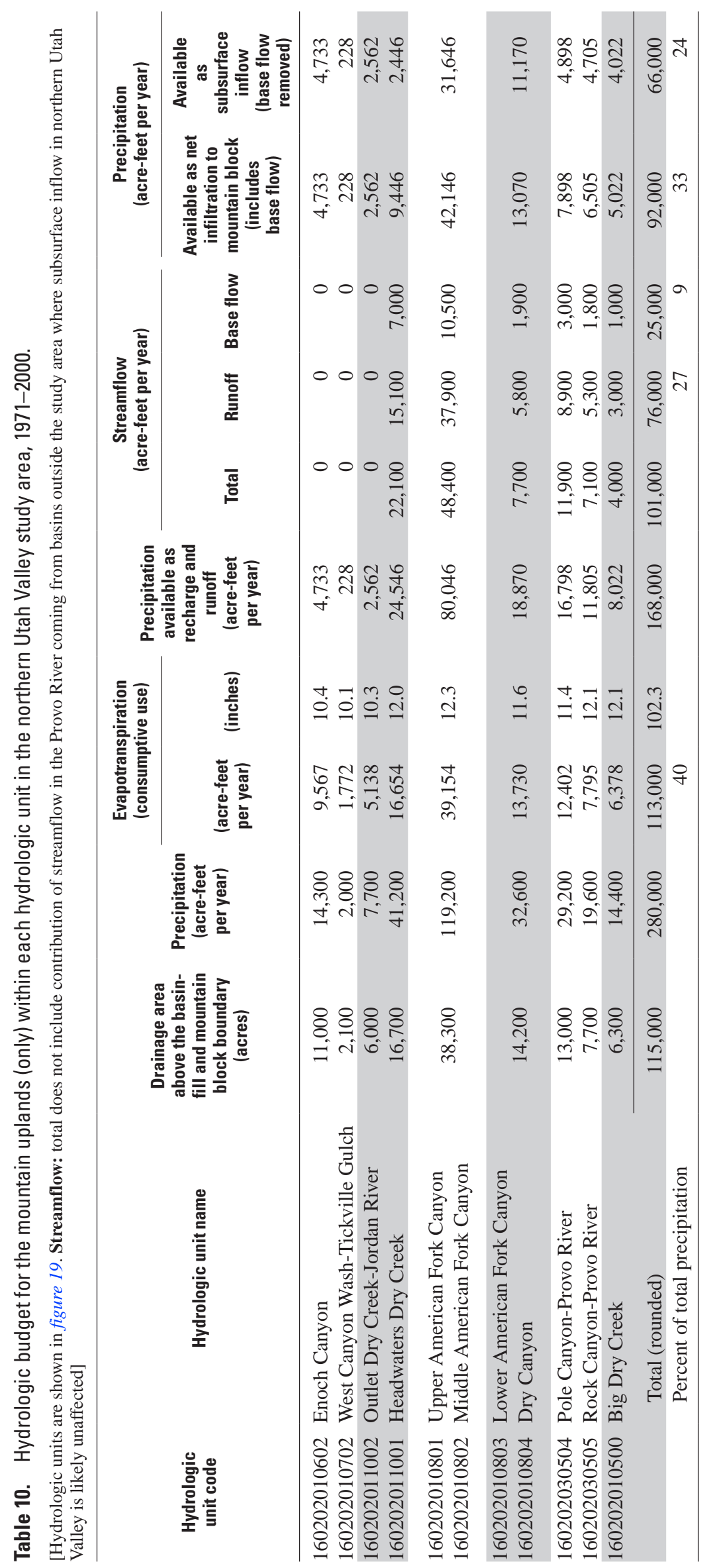


Table 11. Consumptive-use estimates for vegetation and land cover throughout the mountain block of the northern Utah Valley study area, Utah, 2002.

[Developed land: Estimated use 0.1 foot per year. Barren land: Estimated use 1.4 feet per year (Tomlinson, 1996a, table 5). Deciduous forest: Estimated use 1.2 feet per year (American Society of Civil Engineers, 1989, p. 19); Pasture or hay: Estimated use 1.8 feet per year (Utah State University, 1994, p. 234). Shrub or scrub: Estimated use 0.8 foot per year (Branson and others, 1970, fig. 14). Water: Estimated use 2.9 feet per year (Utah State University, 1994, p. 235). Woody wetland: Estimated use 2.4 feet per year (Tomlinson, 1996a, table 5). G rassland: Estimated use 1.0 foot per year (Wight and others, 1986, table 2; and Tomlinson, 1996b, p. 63). Evergreen forest: Estimated use 1.2 feet per year (Brown and Thompson, 1965, table 3; and Kaufmann, 1984, table 2). Mixed forest: Estimated use 1.2 feet per year (Brown and Thompson, 1965, table 3; Kaufmann, 1984, table 2; and American Society of Civil Engineers, 1989, p. 19).

Abbreviation: - , not applicable]

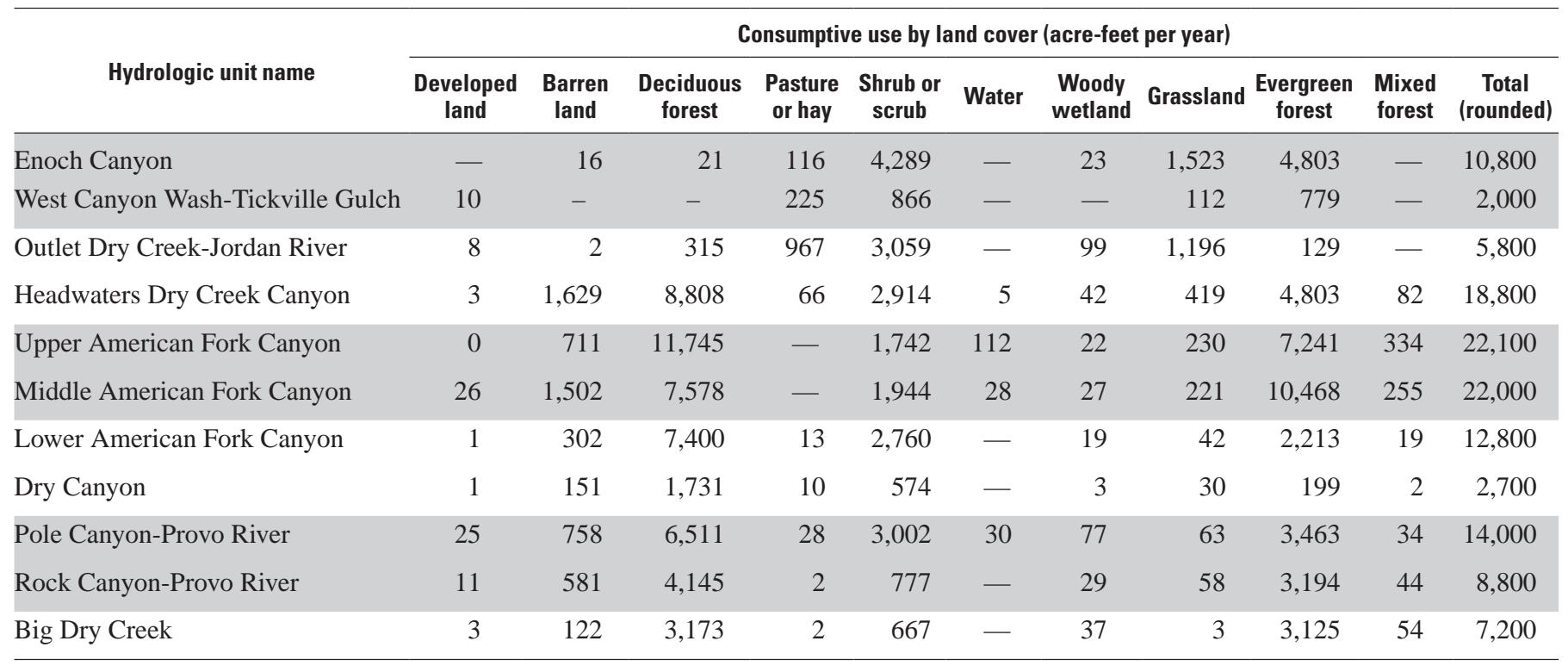

Table 12. Net infiltration to the mountain block and mountain-block subsurface inflow to the basin-fill aquifer in the northern Utah Valley study area, Utah, 1971-2000.

[All values are in acre-feet per year. Abbreviation: BCM, Basin Characterization Model]

\begin{tabular}{|c|c|c|c|c|c|c|c|c|}
\hline \multirow{3}{*}{ Hydrologic unit name } & \multirow{3}{*}{ Precipitation } & \multicolumn{3}{|c|}{ Net infiltration (includes base flow) } & \multirow{3}{*}{$\begin{array}{l}\text { Base } \\
\text { flow }\end{array}$} & \multicolumn{3}{|c|}{ Mountain-block inflow } \\
\hline & & \multirow{2}{*}{$\begin{array}{c}\text { Mountain- } \\
\text { block } \\
\text { hydrologic } \\
\text { budget }\end{array}$} & \multicolumn{2}{|c|}{ BCM } & & \multirow{2}{*}{$\begin{array}{l}\text { Mountain- } \\
\text { block } \\
\text { hydrologic } \\
\text { budget }\end{array}$} & \multirow{2}{*}{$\begin{array}{l}\text { Adjusted } \\
\text { BCM minus } \\
\text { base flow }\end{array}$} & \multirow{2}{*}{$\begin{array}{l}\text { Northern Utah } \\
\text { Valley model } \\
\text { output } \\
\text { (Clark and } \\
\text { Appel, 1985) }\end{array}$} \\
\hline & & & Initial & Adjusted & & & & \\
\hline Outlet Dry Creek-Jordan River & 7,700 & 2,562 & 200 & 200 & 0 & 2,562 & 200 & 0 \\
\hline Headwaters Dry Creek & 41,200 & 9,446 & 5,100 & 7,100 & ${ }^{1} 7,000$ & 2,446 & 0 & 15,900 \\
\hline $\begin{array}{l}\text { Upper American Fork Canyon } \\
\text { Middle American Fork Canyon }\end{array}$ & 119,200 & 42,146 & 15,400 & 35,000 & 10,500 & 31,646 & 24,500 & 29,000 \\
\hline Rock Canyon-Provo River & 19,600 & 6,505 & 4,700 & 4,700 & 1,800 & 4,705 & 2,900 & 22,900 \\
\hline Big Dry Creek & 14,400 & 5,022 & 2,600 & 2,600 & 1,000 & 4,022 & 1,600 & 13,200 \\
\hline Total (rounded) & 280,200 & 91,600 & 46,900 & 68,500 & 25,200 & 66,000 & 43,200 & 112,000 \\
\hline \multicolumn{6}{|c|}{ Percent of precipitation that becomes mountain-block inflow } & 24 & 15 & 40 \\
\hline
\end{tabular}

${ }^{1}$ Base flow in the Dry Creek basin is greater than the calculated net infiltration. 
BCM that likely limits the amount of precipitation that infiltrates into this part of the mountain block is the bedrock geology. Little hydrologic information is available for the granodiorite that crops out in this drainage basin, but it is assumed that it is not permeable. The BCM was not adjusted to account for the possibility of more precipitation infiltrating the mountain block in this area through fractures and (or) faults.

The BCM calculates infiltration of precipitation based partly on potential evapotranspiration, which is the amount of evapotranspiration that would occur if plants and soils had an unlimited supply of water. Because precipitation is often a limiting factor, actual evapotranspiration may be less than potential evapotranspiration. Thus, the 43,200 acre-ft/yr of subsurface inflow calculated from the adjusted BCM is considered the minimum value for mountain-block subsurface inflow. The values for precipitation and streamflow used in the hydrologic budget analysis (equation 3) are reasonably well known. Although uncertainty is associated with the consumptive-use component in the hydrologic budget analysis, the mountainblock subsurface inflow estimate calculated (66,000 acre-ft/yr) is also much lower than previous estimates. Clark and Appel (1985, p. 31) calculated mountain-block subsurface inflow to be 112,000 acre-ft/yr across transect lines that approximate the bedrock/basin-fill contact by using a variation of the Darcy equation. The much lower estimated mountain-block subsurface inflow for this study, as compared to previous studies (less than half), is a result of different calculation methods that incorporate data that were unavailable during previous studies. The updated estimates will be tested in an updated numerical ground-water flow model.

Net infiltration is highly dependent on the amount of precipitation that falls at a particular location. The highest rates of net infiltration (as computed from the BCM) occur at high altitude (fig. 19), corresponding with the highest rates of precipitation. Ground water from net infiltration in the mountain-block aquifer follows flowpaths downgradient and may become subsurface inflow where it flows into the basinfill deposits. Flowpaths may be complicated and deviate from expected patterns as a result of preferential pathways created by faults, fractures, and caverns. Mountain-block inflow that originated in the middle and upper American Fork Canyon HUCs may therefore be distributed across the mountain front near American Fork Canyon as it enters the basin-fill deposits (fig. 19), rather than being focused at the mouth of the canyon as would be expected if mountain-block inflow were to follow surface-water divides. Net infiltration and subsurface inflow occurring within the Provo River Basin was only included for the mountain surface-water basins completely within the study area. It was assumed that net infiltration occurring in the Provo River basin outside of the study area boundary does not become mountain-block subsurface inflow to northern Utah Valley.

\section{Cedar Valley Inflow}

Subsurface inflow from Cedar Valley at the northern end of the Lake Mountains to the principal basin-fill aquifer in northern Utah Valley is estimated to range from 5,000 to $10,000 \mathrm{acre}-\mathrm{ft} / \mathrm{yr}$, with an average flow of 7,500 acre-ft/yr. Feltis (1967, p. 18) estimated subsurface flow out of Cedar Valley to be from 10,000 to 20,000 acre-ft/yr, with outflow occurring at both the north and south ends of the Lake Mountains. Only flow exiting Cedar Valley north of the Lake Mountains enters directly into northern Utah Valley and is accounted for in this report. The sediments in the northern part of Cedar Valley are coarser-grained than sediments in the southern part and have a higher transmissivity, allowing for more flow at the north end of Cedar Valley. Ground-water flow into northern Utah Valley from Cedar Valley occurs in both the unconsolidated basin-fill deposits and fractured bedrock (fig. 9). Water levels in the basin-fill deposits at the north end of the Lake Mountains were generally at an altitude of $4,765 \mathrm{ft}$ in 2004 whereas water levels in the bedrock aquifer were at about 4,520 ft during the same period, indicating a downward hydraulic gradient between the two aquifers in this area. Ground-water flow from Cedar Valley in the fractured limestone bedrock may continue into northern Utah Valley as fracture flow or may become inflow to the WU aquifer. In either case it naturally discharges within the valley bottom.

Clark and Appel (1985, table 8) calculated about 7,500 acre-ft/yr of subsurface inflow to the basin-fill aquifer along the western side of the study area that corresponds to the West Canyon Wash-Tickville Gulch and Enoch Canyon HUCs listed in tables 10,11, and 12 and shown in figure 19. This value was calculated by using Darcy's equation with a head gradient of 0.03 and a transmissivity of $500 \mathrm{ft}^{2} / \mathrm{d}$. Both of these estimates were qualified as being derived from few data points. The transmissivity value is representative of the geology in and along the Lake Mountains but may underestimate the transmissivity of the highly fractured area near the north end of the Lake Mountains.

\section{Discharge}

Ground-water discharge from the principal basin-fill aquifer in northern Utah Valley during 1975-2004 was estimated to be $166,700(+/-25,900)$ acre-ft/yr (table 13). Discharge from the principal basin-fill aquifer occurs through a variety of outlets including wells (pumping and flowing), seepage to waterways, drains, ditches, and springs around Utah Lake, springs and diffuse seepage beneath Utah Lake, diffuse seepage to the Jordan River, evapotranspiration, and subsurface outflow to Salt Lake Valley at Jordan Narrows.

\section{Wells}

Discharge from wells within northern Utah Valley for 2003-04 was calculated to be 58,800 acre-ft/yr. The average annual discharge from wells during 1975-2004 was calculated 


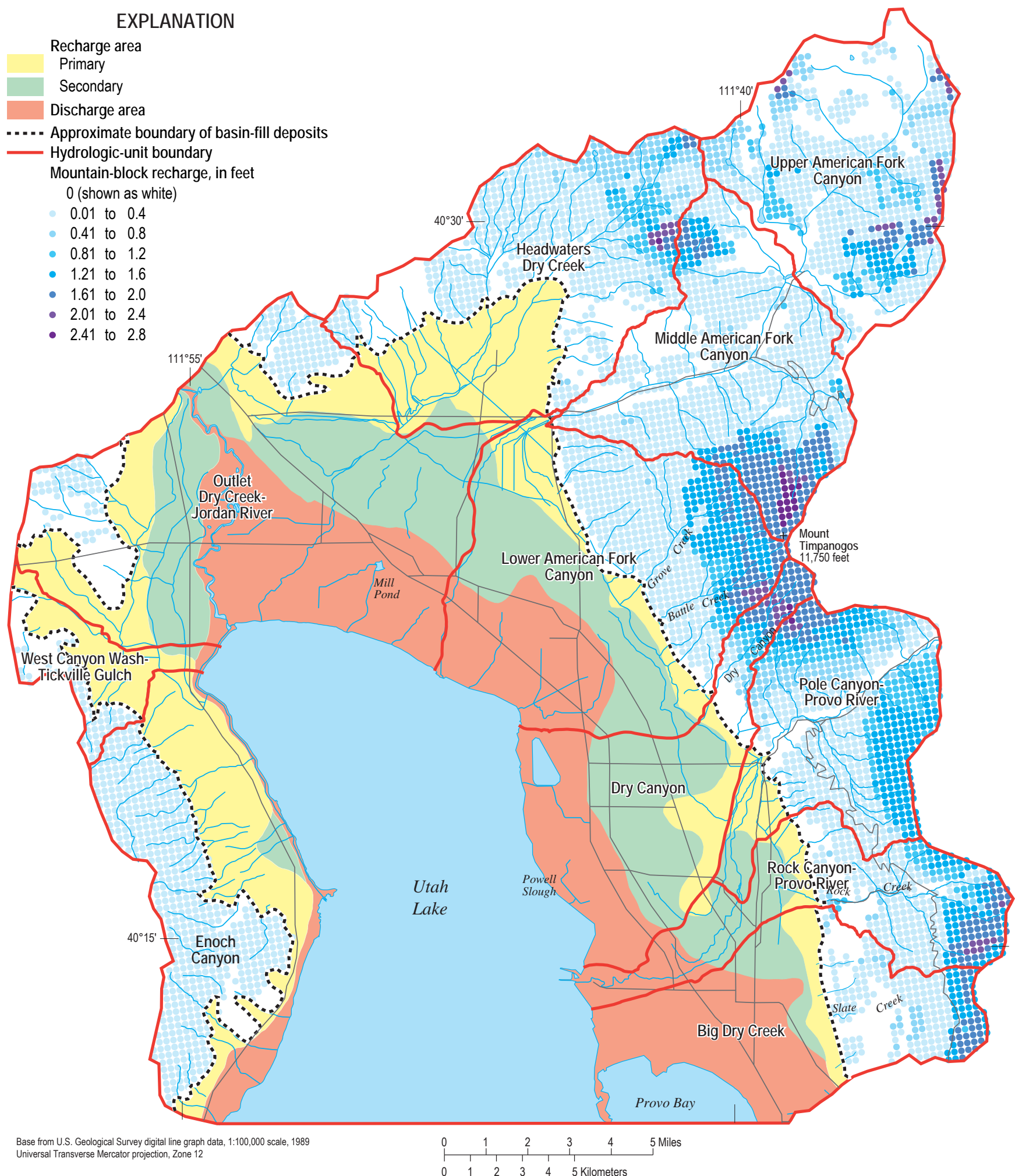

Figure 19. Distribution of net infiltration in the mountain block as computed from the adjusted Basin Characterization Model, northern Utah Valley study area, Utah. 
Table 13. Discharge components of the hydrologic budget for the principal basin-fill aquifer in northern Utah Valley, Utah, $1975-2004$. [All values in acre-feet per year. Bold values indicate total. A bbreviations: —, value not calculated due to lack of available data; \pm , plus or minus]

\begin{tabular}{|c|c|c|}
\hline Discharge source & $\begin{array}{l}1975-2004 \\
\text { Average annual (estimated error) }\end{array}$ & 2004 \\
\hline \multicolumn{3}{|l|}{ Wells } \\
\hline Flowing & 24,500 & 8,300 \\
\hline Stock & 5,000 & 3,600 \\
\hline Waterways, drains, ditches, and springs around Utah Lake & $69,000( \pm 6,900)$ & 54,700 \\
\hline Springs and diffuse seepage beneath Utah Lake & $25,500( \pm 6,000)$ & 20,400 \\
\hline Ground-water seepage to Jordan River & $3,100( \pm 700)$ & 2,500 \\
\hline Evapotranspiration from ground water & $5,500( \pm 1,500)$ & 4,400 \\
\hline
\end{tabular}

to be $61,000(+/-10,000)$ acre-ft (table 13). About 52 percent (31,500 acre-ft) of the 1975-2004 average discharge results from pumping wells whereas about 80 percent (46,900 acre-ft) of the 2004 discharge comes from pumping wells. Pumped wells are used primarily for municipal, industrial, and irrigation supply. The remainder of total well discharge comes from flowing wells, generally used for irrigation, stock watering, and single family domestic supply.

\section{Pumping Wells}

Discharge from pumping wells in 2004 was calculated to be 46,900 acre-ft (table 13). Average annual discharge from pumping wells including municipal, industrial, irrigation, and domestic wells was 31,500 acre-ft during 1975-2004 (table 13). During the same period, the minimum and maximum amount pumped was about 11,200 acre-ft in 1978 and 58,100 acre-ft in 2001, respectively (fig. 20).

Discharge from municipal and industrial wells was calculated from annual pumping records reported to the Utah Department of Natural Resources, Division of Water Rights, and by local water users. Discharge from pumped irrigation wells is estimated annually by the USGS from flow measurements and corresponding power-consumption records. Discharge from pumped domestic wells was estimated by multiplying the number of domestic wells in the recharge areas by an average domestic usage of 1 acre-ft/yr (Clark and Appel, 1985, p. 76). Domestic wells in the discharge area are addressed in the following "Flowing Wells" section of this report.

Discharge from pumping irrigation wells varies from year to year depending on water demand, which is generally a factor of local environmental conditions including summertime temperature and annual precipitation. In general, discharge from pumping wells has increased since 1975 with most of the increase occurring from municipal and industrial wells, with a decline or small change in irrigation wells.

\section{Flowing Wells}

Discharge from flowing wells, not including stock wells, in the principal basin-fill aquifer during 2004 was 8,300 acre$\mathrm{ft}$ (table 14). Average annual discharge from flowing wells was estimated to be 24,500 acre-ft in northern Utah Valley for 1975-2004 (table 14). During the same period, the minimum annual discharge was 8,300 acre-ft in 2004 and the maximum was 39,500 acre-ft in 1984 (fig. 20). Flowing-well discharge was estimated by correlating measured well discharge during 1981-82 reported by Clark and Appel (1985) and 2003-04 to long-term water-level records in selected wells.

Clark and Appel (1985, p. 71) conducted a detailed study during 1981-82 to estimate discharge from flowing irrigation wells. The annual discharge from flowing wells was calculated to be 28,000 acre-ft on the basis of measured well discharge from wells with varying diameters. The total number of irrigation wells in the discharge area was multiplied by the average measured flow for each well diameter. It was assumed that well valves were opened to allow flow an average of 10 weeks per year for crop irrigation. Discharge from nine wells measured in 2004 also was measured in 1982. Comparing water level and well discharge from the two measurement periods (fig. 21 and table 15) did not result in a uniform distribution in change in discharge as a function of the change in head. The comparison could be influenced by many factors between wells including varying aquifer properties of hydraulic conductivity and storage, depth to open intervals, different contributing aquifers, and clogging of well openings over time. Therefore, the assumption was made that, on a valleywide scale, a 1:1 relation between head and discharge was a 


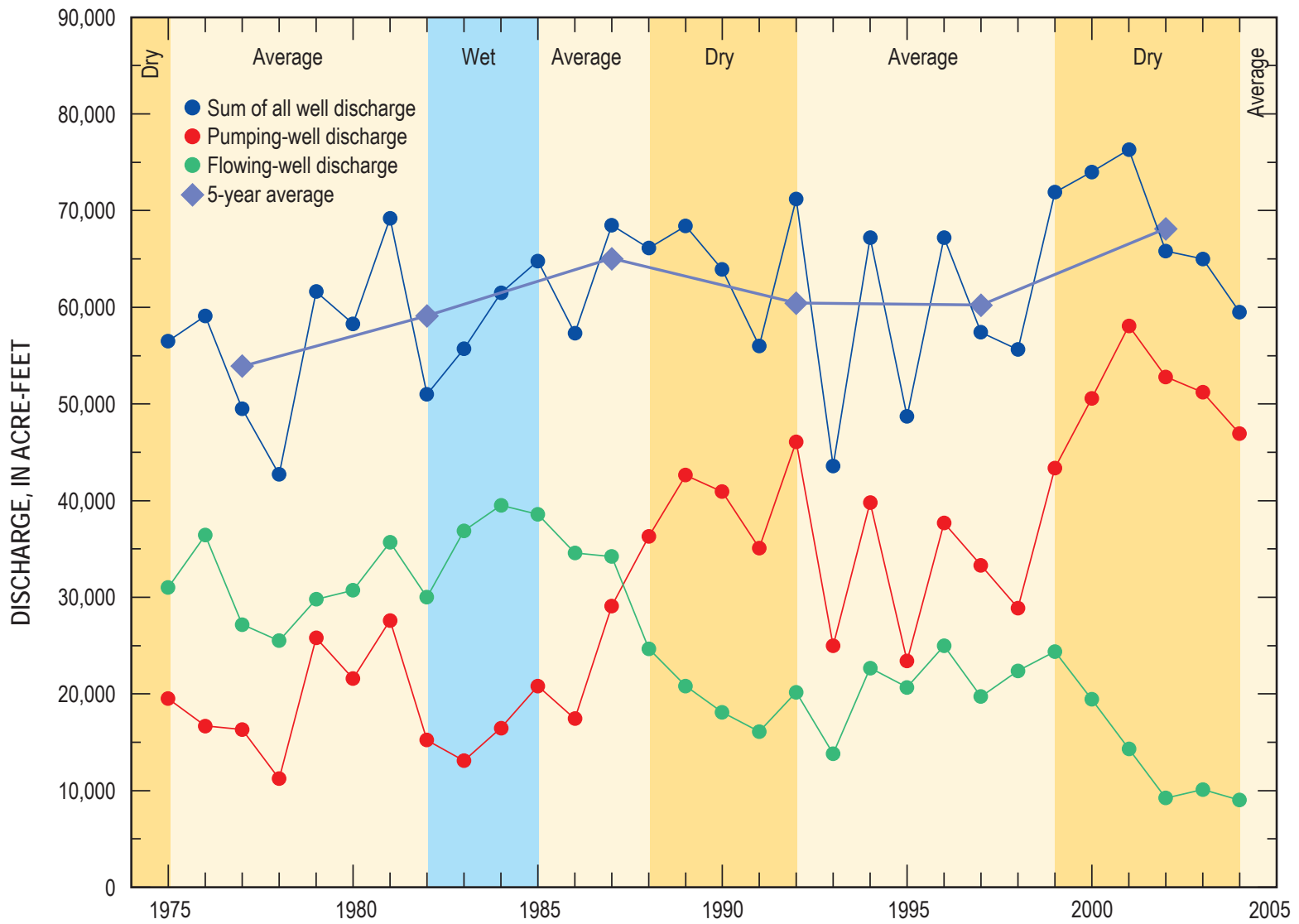

Figure 20. Annual discharge from flowing and pumping wells in northern Utah Valley, Utah, 1975-2004.

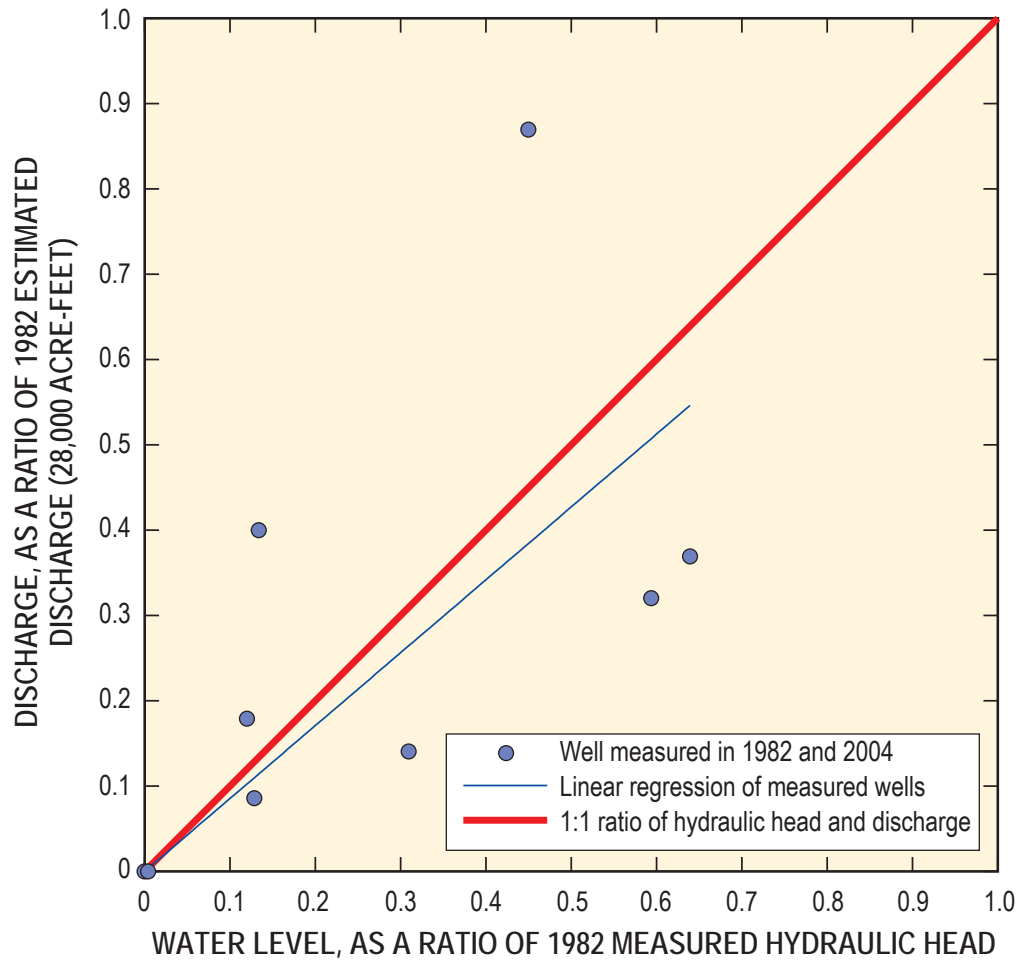

Figure 21. Relation of measured water level and flowing-well discharge in 2004, as a ratio of 1982 measured values, northern Utah Valley, Utah. 
Table 14. Annual well discharge from the principal basin-fill aquifer in northern Utah Valley, Utah, 1975-2004.

[All values are in acre-feet. Stock: estimate includes both flowing and pumping wells. Abbreviations: e, estimated; \pm , plus or minus]

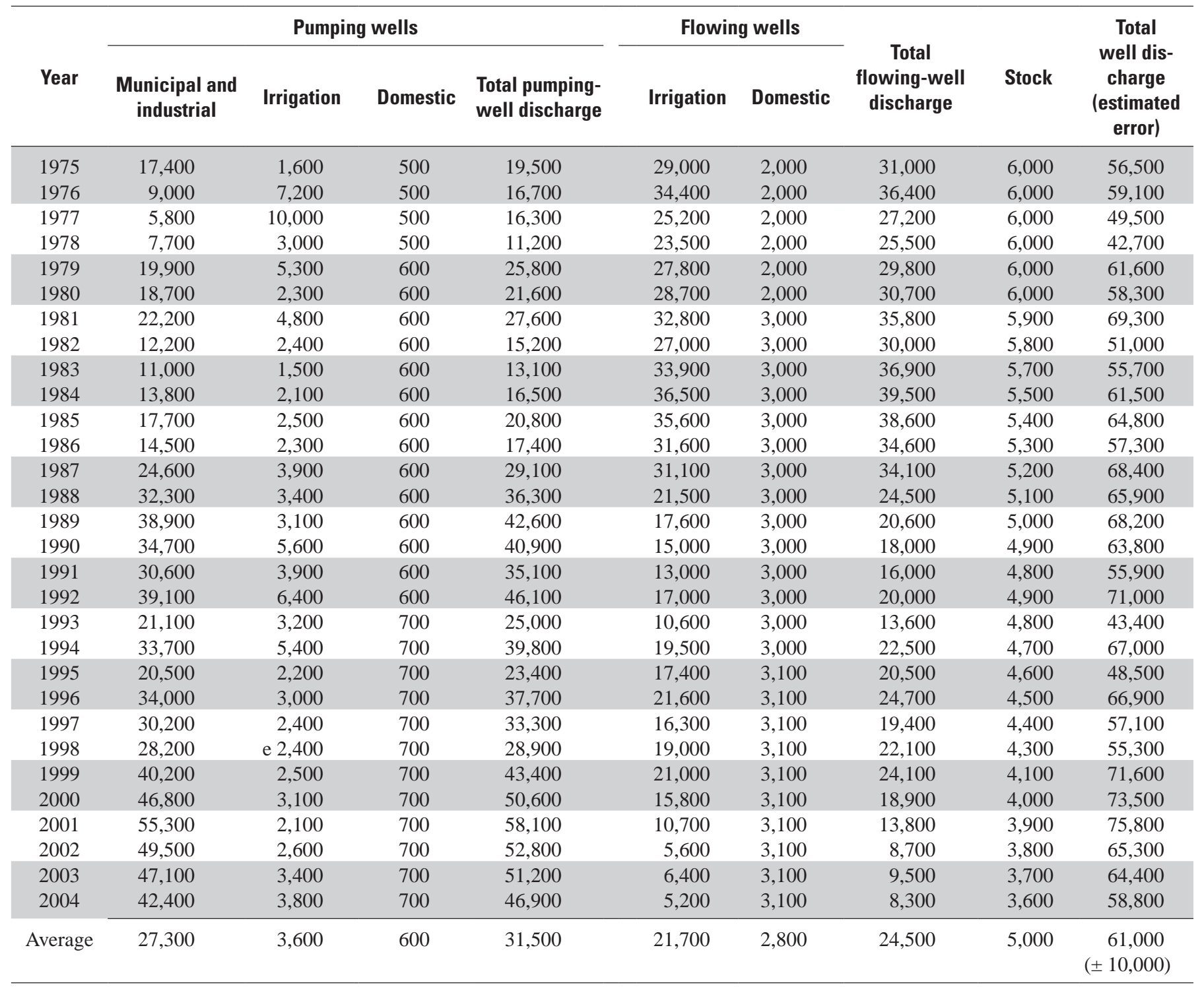

reasonable fit to the measured data and could be used where flowing-well discharge is related to valley wide hydraulic head as measured in representative wells.

Typical discharge conditions for flowing irrigation wells (fig. 22) were computed by using two wells with long-term (more than 30 years) annual water-level measurements. Water levels for these wells are listed in table 16. The northernmost well, (D-5-1)19bcb-2, is located along the north shore of Utah Lake west of Lehi and completed in the DP aquifer. The southernmost well, (D-7-2)3dad-1, is located west of Provo near Provo Bay and completed in the SP aquifer. The wells were selected on the basis of multiple factors including the availability of long-term water-level data, completion in different and distinct aquifers, comparison with other longterm measurements indicating similar water-level response in respective areas, and water levels that have not declined below land surface historically. The selected wells are in continued use and monitoring is expected to be continued into the future, allowing further evaluation.

Water levels, measured annually at wells (D-5-1)19bcb-2 and (D-7-2)3dad-1, were adjusted to represent annual changes in the wells relative to 1982, when Clark and Appel (1985) conducted their well-discharge survey. The water-level measurements were adjusted by dividing the measured water level in each year by the 1982 water level for each respective well, thus resulting in a relative water level (table 16). The normalized water levels for the two wells were averaged together to represent valley-wide discharge conditions that result from changes in the ground-water level in the discharge area for 1975-2004. Relating the annual relative water levels (normalized to 1982) to the estimated 1982 flowing irrigation-well discharge results in a water-level-dependent annual estimate 
Table 15. Well characteristics, water level, and discharge from flowing wells in northern Utah Valley, Utah, 1982 and $2003-04$. [Well identifier: see front of report for an explanation of the well-numbering system used in Utah. Contributing aquifer: SP, shallow Pleistocene; DP, deep Pleistocene; e, estimated; - , unknown]

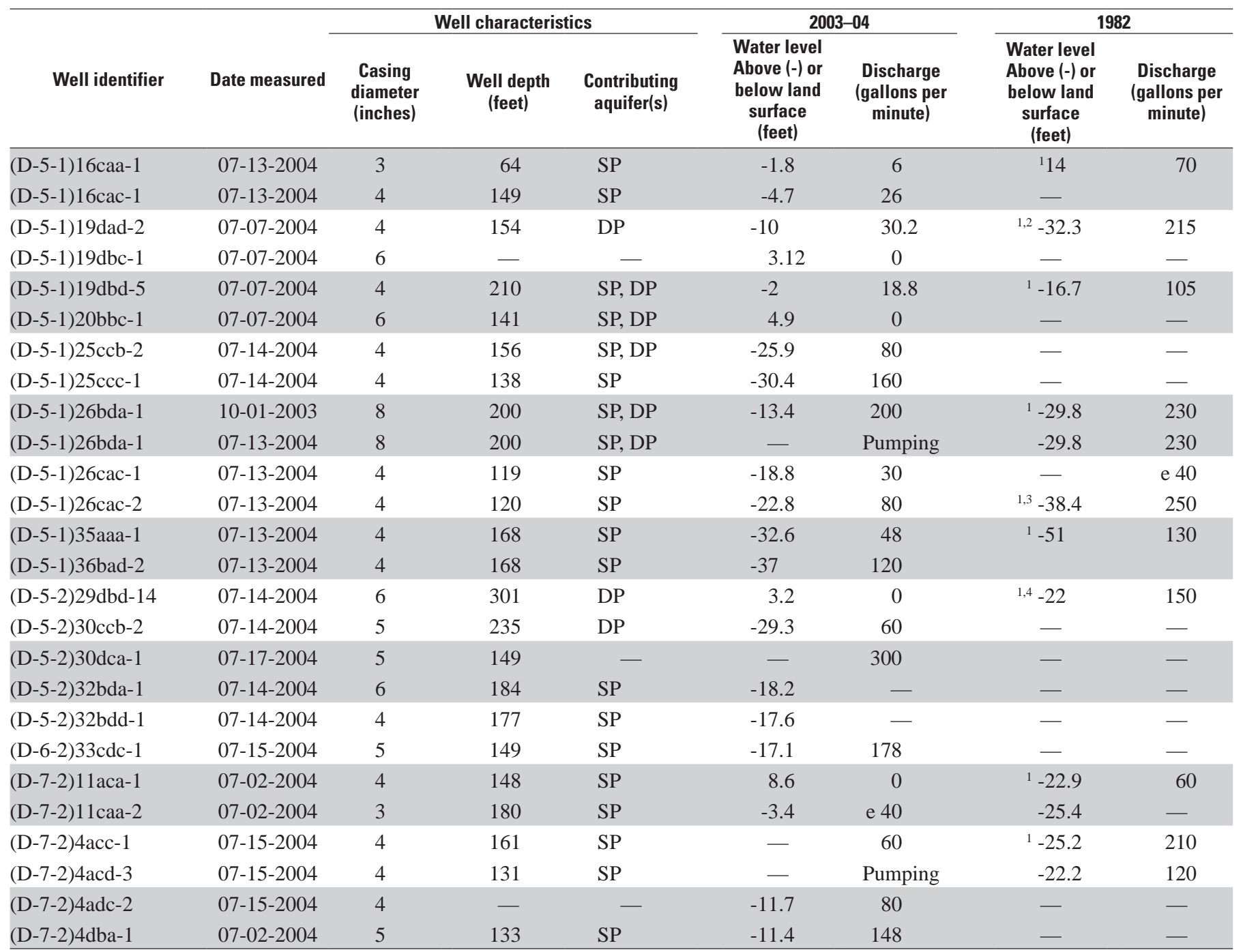

${ }^{1}$ Well discharge and water level was used to determine correlation between 1982 and 2004 discharge.

${ }^{2}$ Discharge and water-level data from drillers' log in 1983.

${ }^{3}$ Discharge and water-level data from drillers' log in 1944.

${ }^{4}$ Discharge and water-level data from drillers' log in 1976.

of irrigation flowing-well discharge (table 16). The estimated discharge assumes that flowing irrigation wells discharge for 10 weeks per year during the growing season, as per Clark and Appel (1985) and communication with local water users. Wells may be used more frequently during dry years when surface-water sources may not be available for irrigation purposes, resulting in more discharge from flowing wells than is estimated by this method. Conversely, not all fields are irrigated in a single year and respective wells are not used in every year, resulting in less discharge from some flowing wells than is estimated. These confounding factors are assumed to result in relatively small effects and were not considered when creating table 16 or figure 22 .
Irrigation flowing-well discharge was reduced to reflect the decrease in irrigated land in northern Utah Valley caused by urbanization for 1966-80, 1980-88, 1988-95, and 1995-2002 when land-use data were compiled (table 3 ). Where land use has changed from irrigated agriculture to commercial and residential, a proportional amount of water is no longer used for irrigation purposes, and the average effect of decreasing the number of wells used for irrigation is reflected in the adjusted plot shown in figure 22. Alternatively, irrigation flowing-well discharge was adjusted (increased) annually by the number of new irrigation wells drilled within the discharge area. The number of large-diameter wells drilled annually during 1982-2004 was provided by the Utah Department of Natural Resources, Division of Water Rights. Increased annual discharge was 


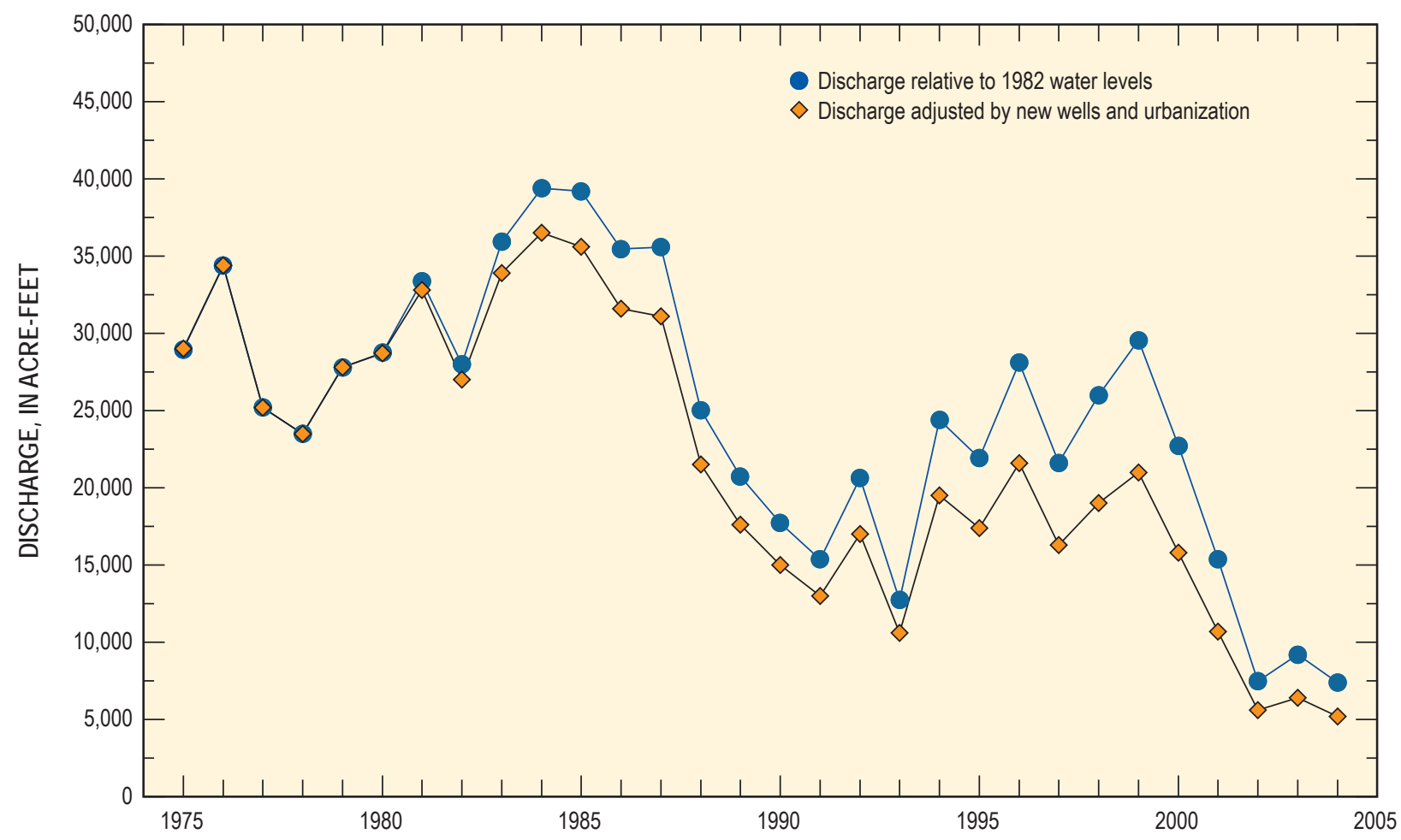

Figure 22. Calculated flowing irrigation-well discharge adjusted to reflect the addition of new wells and removal of existing wells within the discharge area of northern Utah Valley, Utah, 1975-2004.

calculated by multiplying the number of new irrigation wells by the estimated flowing-well discharge for an average well diameter reported in Clark and Appel (1985).

Discharge from flowing domestic wells was estimated annually by multiplying the number of existing and new domestic wells in the discharge area by an average domestic usage of 1.5 acre-ft/yr, as was used in Clark and Appel (1985). They assumed this value was higher than the $1 \mathrm{acre-ft} / \mathrm{yr}$ estimate for pumping domestic wells because there was no electrical charge for usage and because wells often are left partially open during winter months to keep them from freezing.

Discharge from stock wells was estimated annually by multiplying the number of existing and new stock wells in northern Utah Valley by an average discharge of 32 acre-ft/ yr (Clark and Appel, 1985, p. 76). Conversion of agricultural land to commercial and residential land uses is concurrent with reduced livestock practices in northern Utah Valley; therefore, the estimated annual discharge from stock wells was decreased proportionally to the amount of urban growth, as determined from 1980 and 2002 land-use data.

\section{Waterways, Drains, Ditches, Springs, and Diffuse Seepage}

Ground water discharges in the valley lowlands through waterways, drains, and springs around the perimeter of Utah Lake, and from springs and diffuse seepage within Utah Lake and the Jordan River. Average annual discharge from these components during 1975-2004 is estimated to be about 97,600 $(+/-13,600)$ acre-ft (table 13) or about 59 percent of the total ground-water discharge from the principal basin-fill aquifer. Estimates of discharge from diffuse seepage and springs within Utah Lake are based on few data and may be a large source of error.

\section{Waterways, Drains, Ditches, and Springs around Utah Lake}

Natural discharge from the principal basin-fill aquifer to waterways, drains, ditches, and springs, occurring throughout the valley lowlands surrounding Utah Lake, was estimated to be about 55,000 acre-ft/yr in 2003-04 (tables 13 and 17). Discharge measurements at most of the waterways, drains, ditches, and springs entering Utah Lake (fig. 23) were made at access points near Utah Lake during September 2003 and March, June, and December 2004. Discharge from waterways, drains, ditches, and springs that was not measured 
Table 16. Measured water levels, water levels relative to 1982 levels, and calculated flowing irrigation-well discharge in northern Utah Valley, Utah, 1975-2004.

[See front of report for an explanation of the well-numbering system used in Utah. Bold indicates reference year for calculation. Abbreviations: e, estimated; - , not calculated]

\begin{tabular}{|c|c|c|c|c|c|c|c|c|c|c|}
\hline \multicolumn{3}{|c|}{ Well (D-5-1)19bcb-2 } & \multicolumn{3}{|c|}{ Well (D-7-2)3dad-1 } & \multicolumn{5}{|c|}{ Calculated flowing irrigation-well discharge } \\
\hline $03-02-76$ & -29.65 & 1.12 & $03-04-76$ & -14.3 & 1.34 & 1.23 & 34,400 & - & - & 34,400 \\
\hline 03-03-77 & -24.9 & .94 & 03-07-77 & -9.2 & .86 & .90 & 25,200 & - & - & 25,200 \\
\hline $03-06-78$ & -23.4 & .88 & $03-08-78$ & -8.5 & .79 & .84 & 23,500 & - & - & 23,500 \\
\hline 03-13-79 & -26.1 & .98 & $03-15-79$ & -10.71 & 1.00 & .99 & 27,800 & - & - & 27,800 \\
\hline $03-06-80$ & -26.14 & .99 & $03-03-80$ & -11.4 & 1.06 & 1.03 & 28,700 & - & - & 28,700 \\
\hline $03-06-81$ & -29.5 & 1.11 & $03-02-81$ & -13.6 & 1.27 & 1.19 & 33,400 & - & 600 & 32,800 \\
\hline $03-05-86$ & -31.7 & 1.20 & $03-07-86$ & -14.3 & 1.34 & 1.27 & 35,500 & 300 & 4,200 & 31,600 \\
\hline $03-05-87$ & -30.2 & 1.14 & $03-04-87$ & -15.0 & 1.40 & 1.27 & 35,600 & 400 & 4,900 & 31,100 \\
\hline 03-04-88 & -25.6 & .97 & $03-02-88$ & -8.8 & .82 & .89 & 25,000 & 500 & 4,000 & 21,500 \\
\hline 03-08-89 & -19.2 & .72 & 03-09-89 & -8.1 & .76 & .74 & 20,700 & 500 & 3,600 & 17,600 \\
\hline $03-01-90$ & -18.7 & .71 & $03-05-90$ & -6.0 & .56 & .63 & 17,700 & 600 & 3,300 & 15,000 \\
\hline 03-06-91 & -17.7 & .67 & $03-05-91$ & -4.6 & .43 & .55 & 15,400 & 700 & 3,100 & 13,000 \\
\hline $03-04-92$ & -20.2 & .76 & $03-10-92$ & -7.61 & .71 & .74 & 20,600 & 800 & 4,400 & 17,000 \\
\hline $03-02-93$ & -15.3 & .58 & $03-04-93$ & -3.54 & .33 & .45 & 12,700 & 800 & 2,900 & 10,600 \\
\hline 03-03-94 & -20.4 & .77 & 03-09-94 & -10.4 & .97 & .87 & 24,400 & 900 & 5,800 & 19,500 \\
\hline 03-03-95 & -19.2 & .72 & 03-09-95 & -9.0 & .84 & .78 & 21,900 & 1,000 & 5,500 & 17,400 \\
\hline $03-05-96$ & -21.0 & .79 & 03-08-96 & -13.0 & 1.21 & 1.00 & 28,100 & 1,100 & 7,600 & 21,600 \\
\hline Average & -22.86 & 0.86 & & -9.86 & 0.92 & 0.88 & 24,700 & 800 & 4,600 & 21,700 \\
\hline
\end{tabular}

was estimated. Estimates were based on other measurements made at each site during the study period, visual inspection, or by applying a ratio to the 1981-82 measured values based on measurements at sites measured in both 1981-82 and 2003-04. The minimum combined flow of measured and estimated inflows to the lake was about $64 \mathrm{ft}^{3} / \mathrm{s}(46,000$ acre- $\mathrm{ft} / \mathrm{yr})$ in June 2004; the maximum combined flow was about $88 \mathrm{ft}^{3} / \mathrm{s}$ (64,000 acre-ft/yr) in March 2004; and during September 2003 and December 2004, the total combined flow was about 75 $\mathrm{ft}^{3} / \mathrm{s}(54,000$ acre-ft/yr) for each period (table 17). These measurements were made when irrigation diversions and snowmelt runoff were at a minimum and therefore are considered to be representative of base-flow conditions. The 1975-2004 aver- age annual discharge was estimated to be $69,000(+/-6,900)$ acre-feet (table 13) as determined by calculating the average of measured flows from the three ground-water studies conducted for northern Utah Valley including Cordova and Subitzky (1965), 53,000 acre-ft/yr; Clark and Appel (1985), 100,000 acre-ft/yr; and this study, 55,000 acre-ft/yr.

Clark and Appel (1985, table 15) reported an average value of 100,000 acre-ft/yr for discharge from drains, ditches, and springs, almost double the estimated 2003-04 value in this report. This estimate was based primarily on discharge measurements made in the fall of 1981 and the spring and fall of 1982. The decrease in estimates for this study is a result of decreased hydrostatic pressure in the confined aquifers, 
Table 17. Discharge from waterways, drains, ditches, and springs around Utah Lake in northern Utah Valley, Utah, $2003-04$.

[Site identifer shown on figure 23. See front of report for an explanation of the well-numbering system used in Utah. All values in cubic feet per second. Abbreviations: e, estimated]

\begin{tabular}{|c|c|c|c|c|c|c|}
\hline Site identifer & Local identifier & \multicolumn{4}{|c|}{ Measurement period } & Average \\
\hline 2 & $(\mathrm{C}-5-1) 25 \mathrm{cdc}$ & .294 & e .794 & e .794 & 1.29 & .794 \\
\hline 3 & $(\mathrm{C}-5-1) 25 \mathrm{cac}$ & .585 & e 1.37 & e 1.37 & 2.15 & 1.37 \\
\hline 7 & (D-5-1)20dcb & e .106 & .184 & .034 & .101 & .106 \\
\hline 8 & (D-5-1)21ccb & .786 & e .5 & e 0 & e .5 & e .5 \\
\hline 9 & (D-5-1)21cac & .188 & .111 & .041 & .435 & .194 \\
\hline 10 & (D-5-1)21adb & .832 & 1.70 & .692 & 1.47 & 1.17 \\
\hline 11 & (D-5-1)21adb & 2.90 & 8.29 & .777 & 9.54 & 5.38 \\
\hline 12 & (D-5-1)27bbd & e 1 & e 1 & e 1 & e 1 & e 1 \\
\hline 17 & (D-5-1)36bbb & 1.06 & 1.45 & .651 & 1.13 & 1.07 \\
\hline 18 & (D-5-1)36bab & .555 & .973 & 1.00 & .694 & .806 \\
\hline 19 & (D-5-1)36aab & 1.03 & 1.29 & 1.99 & 1.48 & 1.45 \\
\hline 20 & (D-6-2)6baa & 8.75 & 9.68 & 10.24 & 10.50 & 9.79 \\
\hline 21 & (D-6-2)6dbc & 14.0 & 12.3 & 1.37 & 3.67 & 7.83 \\
\hline 22 & (D-6-2)7abb & e 1.5 & e 1.5 & e 1.5 & 1.50 & 1.50 \\
\hline 23 & (D-6-2)7dcc & 0 & 0 & 0 & 0 & 0 \\
\hline 24 & (D-6-2)18abb & .977 & 2.20 & 4.68 & .463 & 2.08 \\
\hline 25 & (D-6-2)29cbb & 2.55 & 2.83 & .277 & .010 & 1.42 \\
\hline 26 & $(\mathrm{D}-6-2) 29 \mathrm{cdb}$ & .861 & 4.63 & 2.88 & 2.95 & 2.83 \\
\hline 27 & (D-6-2)29dcc & 2.74 & 4.72 & 3.69 & 4.30 & 3.86 \\
\hline 35 & $(\mathrm{D}-7-3) 20 \mathrm{cdb}$ & e 8.2 & e 8.2 & e 8.2 & e 8.2 & e 8.2 \\
\hline Total & (cubic feet per second) & 75 & 88 & 64 & 75 & 76 \\
\hline (rounded) & (acre-feet per year) & 54,000 & 64,000 & 46,000 & 54,000 & 55,000 \\
\hline
\end{tabular}

likely caused by increased ground-water withdrawals and regional drought conditions during and prior to 2003-04. As discussed previously, water levels in wells are generally 10 to $20 \mathrm{ft}$ lower in the discharge area, resulting in reduced natural discharge in 2003-04 as compared to 1981-82. Additionally, though the shallow unconfined LB aquifer is not considered part of the principal basin-fill aquifer, it does act as a conduit for discharge from the confined aquifers. Because of this, the measured flows in this study and past studies include at least some amount of water contributed by the shallow unconfined LB aquifer that has been recharged locally. The contribution from the LB aquifer has likely decreased since the 1980s because recharge to the aquifer has been reduced in response to more-efficient irrigation practices and changes in land use from irrigated agricultural to commercial and residential. The reduction in irrigation is reflected in decreased irrigation canal flows within the Provo River Basin (fig. 24), which follow the same decreasing trend as the measured discharge of waterways, drains, ditches, and springs.

\section{Springs and Diffuse Seepage beneath Utah Lake}

Discharge from the principal basin-fill aquifer to springs beneath Utah Lake and as diffuse seepage beneath Utah Lake within northern Utah Valley was estimated to be about 20,400 acre-ft/yr for 2003-04 with an average annual (1975-2004) 


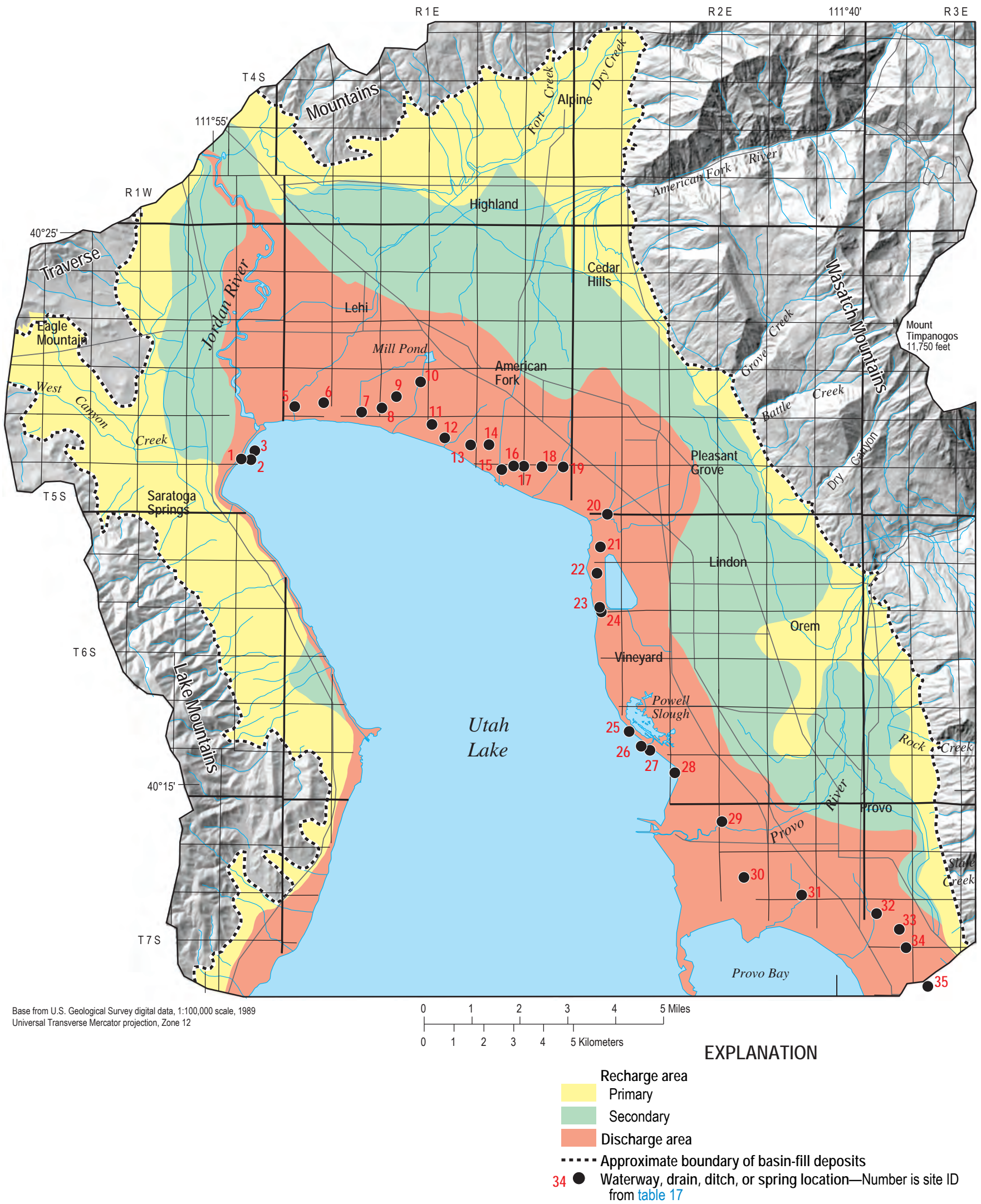

Figure 23. Location of measured waterways, drains, ditches, and springs around Utah Lake in northern Utah Valley, Utah, 2003-04. 


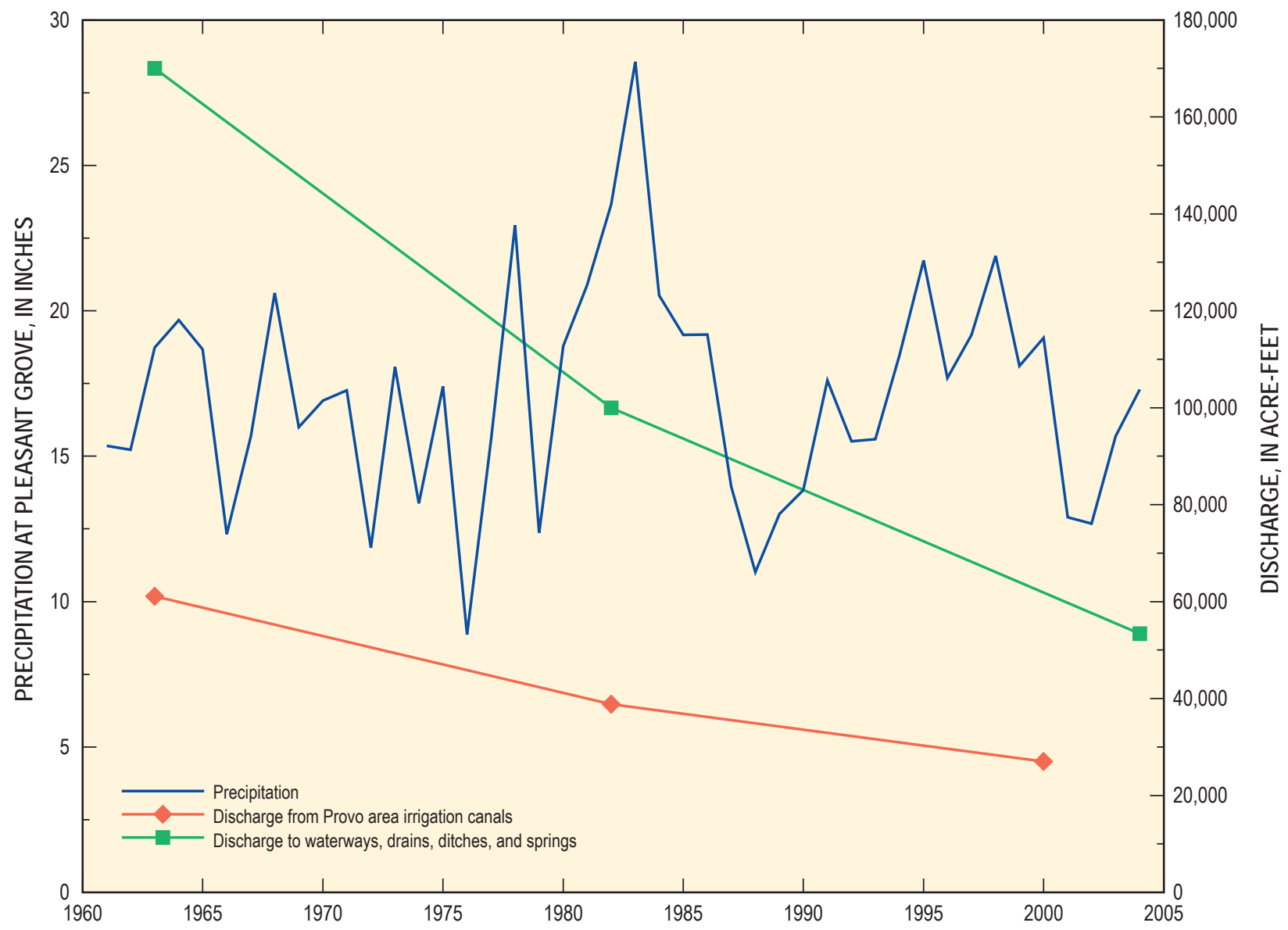

Figure 24. Relation of precipitation, discharge from irrigation canals, and discharge from waterways, drains, ditches, and springs around Utah Lake in northern Utah Valley, Utah.

discharge of about 25,500 (+/- 6,000) acre-ft (table 13). This discharge was estimated to be 30,000 acre-ft/yr by Cordova and Subitzky (1965, p. 19) with an estimated minimum (25,000 acre-ft/yr) and maximum (36,000 acre-ft/yr) discharge occurring in association with changes in hydrostatic pressure within the principal basin-fill aquifer. Clark and Appel (1985, p. 78) noted that these estimates were made in 1937-40 during a drought period. Using 1981 water levels and the Darcy flow equation, Clark and Appel (1985, p. 79) calculated a total discharge of 37,000 acre-ft/yr from springs and as diffuse seepage beneath Utah Lake. The annual discharge reported for this study is calculated by multiplying the Clark and Appel (1985) 37,000 acre-ft/yr estimate by a "drain ratio," calculated by dividing the combined annual waterway, drain, ditch, and spring discharge for the year of interest by the measured combined discharge for 1981-82. For 2003-04, this ratio was 0.55.

A salt-balance analysis using the Utah Lake Water Quality Salinity model (LKSIM) was used by Fuhriman and others (1981) to estimate about 114,000 acre-ft/yr of groundwater discharge within all of Utah Lake. This method used dissolved-solids and selected ion concentrations, along with the amount of surface-water inflow and outflow, precipitation, and change in lake storage, to calculate evaporation from and subsurface inflow to the lake. Refinement and calibration of the LKSIM salt-balance model to annual data for 1930-2003 simulated an average annual inflow of 76,000 acre-ft from the principal basin-fill aquifer to Utah Lake (LeVere B. Merritt, Brigham Young University, written commun., 2005). The model divides ground-water inflow within the lake into discharge from freshwater springs and mineralized (thermal) springs. Fresh ground-water inflow along the eastern part of the lake between Jordan River and Spanish Fork River is simulated to be 23,600 acre-ft/yr. Part of this spring discharge likely occurs south of northern Utah Valley because of flowpaths from the Hobble Creek and Spanish Fork drainage basins, but the amount is not known. To calculate the amount of ground-water discharge by springs in the northern part of Utah Lake, 80 percent of the fresh ground-water inflow along the eastern part of the lake from the Jordan River to the Spanish Fork River simulated by the LKSIM model is estimated to occur in the study area (an average of 18,900 acre-ft/yr during 1930-2003). Average annual flow from thermal springs to Utah Lake in the Saratoga Springs area is simulated by the LKSIM model to be 13,400 acre-ft. Combining the fresh 
and thermal water components provides a 1930-2003 average discharge from springs to the northern part of Utah Lake of 37,000 acre-ft/yr. Spring discharge to the northern part of the lake calculated by the LKSIM salt-balance model in 2003 is $22,000 \mathrm{acre}-\mathrm{ft} / \mathrm{yr}$ and average discharge for $1975-2003$ is $40,300 \mathrm{acre}-\mathrm{ft} / \mathrm{yr}$. In comparison to the estimates for this study (20,400 and 25,500 acre-ft/yr for 2003-04 and 1975-2004, respectively), the LKSIM salt-balance model values are greater but they include inputs from thermal springs that are not quantified in the hydrologic budget.

\section{Ground-Water Seepage to the Jordan River}

Ground-water seepage to the Jordan River between Utah Lake and the Jordan Narrows has been estimated to be 7,000 acre-ft/yr (Cordova and Subitzky, 1965, p. 22). Clark and Appel $(1985$, p. 79$)$ estimated that 50 to 80 percent $(3,500$ to $5,600 \mathrm{acre}-\mathrm{ft} / \mathrm{yr}$ ) of the ground-water seepage was from upward leakage from the principal confined basin-fill aquifer with the remainder occurring as seepage from the shallow unconfined LB aquifer. By using these previously published estimates and multiplying this discharge by the previously defined drain ratio of 0.55 for 2003-04, it was estimated that discharge from the principal confined basin-fill aquifer to the Jordan River was 2,500 acre-ft in 2004. The 1975-2004 average annual discharge was estimated to be 3,100 (+/- 700) acre-ft, based on a drain ratio of 0.69 .

\section{Evapotranspiration}

Ground-water discharge from the principal basin-fill aquifer resulting from evapotranspiration was estimated to be 4,400 acre-ft in 2004 with an average 1975-2004 annual discharge of $5,500(+/-1,500)$ acre-ft. Evapotranspiration from the confined basin-fill aquifers in northern Utah Valley during 1981-82 was estimated to be 8,000 acre-ft/yr by Clark and Appel (1985, p. 83). Plant consumptive use was calculated for about 16,000 acres around Utah Lake. This area included about 5,500 acres of native vegetation (excluding grasses) and about 10,400 acres of crops and grasses, most of which receives water applied as irrigation. Estimates were made on how much water was supplied by the different sources (precipitation, irrigation, ground water) to meet the consumptive-use requirements. Data were not collected as part of this study on evapotranspiration by phreatophytes. The effective area mapped by Clark and Appel (1985, fig. 43) likely has decreased because of water-level declines within the aquifers and land-use changes for the study period. Estimates of evapotranspiration for this study, therefore, were scaled by the drain ratio defined previously.

\section{Subsurface Outflow to Salt Lake Valley}

Ground-water flow from the principal confined basin-fill aquifer out of northern Utah Valley into Salt Lake Valley at the Jordan Narrows is estimated to be from 2,000 to 3,300 acre-ft/ $\mathrm{yr}$, with an average value of about 2,600 acre-ft/yr. Estimates of subsurface outflow were originally established by Mower (1970) and revised by Clark and Appel (1985) using Darcy calculations of cross-sectional flow based on hydraulic conductivity, hydraulic gradient, and cross-sectional area. Mower (1970) reported a range of 2,000 to 3,000 acre-ft/yr, depending on the width of the cross section used in his calculation, and a probable average annual flow of 2,500 acre-ft. Clark and Appel (1985), using a different cross section and different hydraulic-conductivity values, calculated a similar annual flow of at least 2,000 acre-ft.

Few wells have been drilled in the Jordan Narrows area since 1985. One well of interest, (C-4-1)26acd-1, was drilled in 1995 near the center of the Clark and Appel (1985) transect. The lithologic log is poorly detailed but notes that bedrock is present at $700 \mathrm{ft}$ below land surface, placing an upper limit on the potential saturated thickness of the basin-fill aquifer near Jordan Narrows. In the area, the SP aquifer generally occurs at about 100 to $150 \mathrm{ft}$ below land surface. Accounting for intervening clay layers within the basin-fill aquifers, the maximum saturated thickness is likely about $500 \mathrm{ft}$. Clark and Appel (1985) used local well logs to estimate a hydraulic-conductivity value of $20 \mathrm{ft} / \mathrm{d}$. Using the maximum saturated thickness and the Clark and Appel values (1985) of hydraulic conductivity $(20 \mathrm{ft} / \mathrm{d})$, hydraulic gradient $(0.006(32 \mathrm{ft} / \mathrm{mi}))$, and crosssectional length $(6,600 \mathrm{ft})$ in Darcy's equation, the maximum outflow to Salt Lake Valley is calculated to be $396,000 \mathrm{ft}^{3} / \mathrm{d}$ or about 3,300 acre-ft/yr. This value is only slightly larger than the upper range estimated by Mower (1970) and reinforces Mowers estimate.

\section{Hydrologic Budget}

The total 1975-2004 average annual amount of water available as recharge and subsurface inflow to the principal basin-fill aquifer in northern Utah Valley is estimated to be about $153,000(+/-31,500)$ acre-ft. Total discharge is estimated to be about 166,700 (+/- 25,900) acre-ft/yr (table 4). A complete hydrologic budget for the period of data collection (2003-04) was not calculated. Various components of the budget, including subsurface inflows and outflows, are generalized data and are assumed to represent average climatic conditions. Because the study occurred during a drought period, utilization of average values to represent components within the 2003-04 hydrologic budget would bias the budget high. The annual average hydrologic budget shows a deficit in recharge of about 14,000 acre-ft/yr, but this difference is likely a result of inherent uncertainty and error in the individual budget estimates rather than an actual deficit.

Estimates of the uncertainty were assessed for each of the budget components to represent a probable range of values. Budget components that are based on field measurements, including stream and canal seepage, irrigated fields, domestic watering (lawns and gardens), and discharge to waterways, drains, ditches, and springs were assigned an uncertainty of 10 
percent based on the precision of the data-collection method. Components that rely heavily on modeled results or regression equations to estimate values were assigned higher uncertainties. These uncertainties range from about 16 percent in the calculation of well discharge to 41 percent in the calculation of recharge from direct infiltration of precipitation on the primary recharge area. Uncertainty of subsurface flow into and out of northern Utah Valley was assumed to be about 30 percent of the calculated value because of the highly variable values of hydraulic conductivity and evapotranspiration used in these calculations.

Comparison of individual measured components in the 2003-04 hydrologic budget to the Clark and Appel (1985) measured components shows a decrease in all of the budget components except for domestic watering of lawns and gardens. This decrease is likely a result of both drier climatic conditions and land-use changes (a decrease in irrigated lands with increased urban development). The measured components with the greatest change and effect on the hydrologic budget include recharge from stream and canal seepage, discharge from wells, and discharge from waterways, drains, ditches, and springs around Utah Lake. These components are highly influenced by climatic conditions and the decrease reflects the drought period during which they were measured. The 55-percent decrease in discharge to waterways, drains, ditches, and springs around Utah Lake is significant and also has a fairly low uncertainty because it was a measured value during both studies. Land-use effects on the budget components are apparent when comparing recharge from irrigated fields and domestic watering (lawns and gardens). The decrease in recharge from irrigated lands and increase in recharge from domestic watering (lawns and gardens) is a direct result of irrigated lands giving way to urban development. Subsurface inflow from the mountain block to the principal basin-fill aquifer decreased by 59 percent from the Clark and Appel (1985) estimate. This difference is likely a result of the incorporation of new methodologies and higher resolution data to calculate subsurface inflow rather than a reflection of actual environmental conditions or changes to the system.

\section{Movement}

Ground water generally flows through the basin-fill deposits in northern Utah Valley from recharge areas at and near the mountain fronts to discharge areas in and near the valley bottom, Utah Lake, and the Jordan River. As previously discussed in the "Sources of Water" section of this report, a downward gradient exists within the primary recharge area along the mountain front (figs. 2 and 3). A downward gradient also exists in the secondary recharge area, but leaky confining layers of fine-grained material impede the downward movement of water and may allow only a portion to leak to the principal confined basin-fill aquifer. Water not able to infiltrate through the fine-grained layers becomes part of the shallow water table (LB) aquifer and localized perched aquifers. At the lower end of the generalized flowpath, near the valley bottom, an upward gradient exists within the confined basinfill aquifers, resulting in ground-water discharge in the form of springs, diffuse seepage, and flowing wells. An intensive water-level survey was completed in March and April of 2004 to determine the distribution of the altitude of the potentiometric surface in the different basin-fill aquifers. Water levels were measured in 269 wells throughout the study area (fig. 25) and used to delineate potentiometric contours for the basinfill aquifer. Measured water levels and well characteristics are listed in appendix A.

\section{Lake Bonneville Unconfined Aquifer}

Recharge to the shallow unconfined LB aquifer and dispersed perched aquifers occurs from direct infiltration of precipitation, seepage from streams and canals, seepage from irrigation and domestic watering, and septic systems. In the valley lowlands, leakage to the LB aquifer occurs as upward movement of water from the deeper confined aquifers where pressure is greater than in the overlying water-table aquifer. Groundwater movement in the LB aquifer generally is similar to the slope of the land surface (Clark and Appel, 1985, p. 49) with recharge occurring on the valley benches and discharge occurring near the valley bottom as springs, diffuse seepage, and evapotranspiration. Water levels measured in seven wells finished in the LB aquifer ranged from about 2 to $42 \mathrm{ft}$ below land surface (appendix A), averaging about $16 \mathrm{ft}$. In general, the perched systems and the LB aquifer are not hydraulically connected laterally, and no attempt was made to identify a potentiometric surface on a valley-wide scale.

\section{Shallow Pleistocene Confined Aquifer}

The potentiometric surface of the SP aquifer (fig. 26) was delineated from water-level measurements collected during March 2004 in 79 wells completed within the SP aquifer. Water levels ranged from an altitude of 4,498.4 ft near Utah Lake to 4,553.1 ft on the Highland Bench. Water-level gradients in the SP aquifer range from a minimum of $0.0009(5 \mathrm{ft} /$ $\mathrm{mi}$ ) in the area west of the Provo Bench (Orem) and continuing down to Powell Slough to a maximum of 0.006 (32 ft/mi) in the area south of the Provo River extending from the mountain front to near Provo Bay, with flow generally toward Utah Lake or the Jordan River. Areas of ground-water discharge, as indicated by the indentation of the potentiometric contour lines in the upgradient direction, include the area surrounding Mill Pond near Lehi, the area south of Geneva near Powell Slough, and the area northeast of Provo Bay. Potentiometric contours also indicate that ground-water flow south of the American Fork River parallels the mountain front to the Grove Creek and Battle Creek drainage basins. Flow is controlled by the substantially greater recharge contribution from the vicinity of the larger American Fork River drainage basin as compared to the small drainage basins of Battle Creek, Grove Creek, and other 


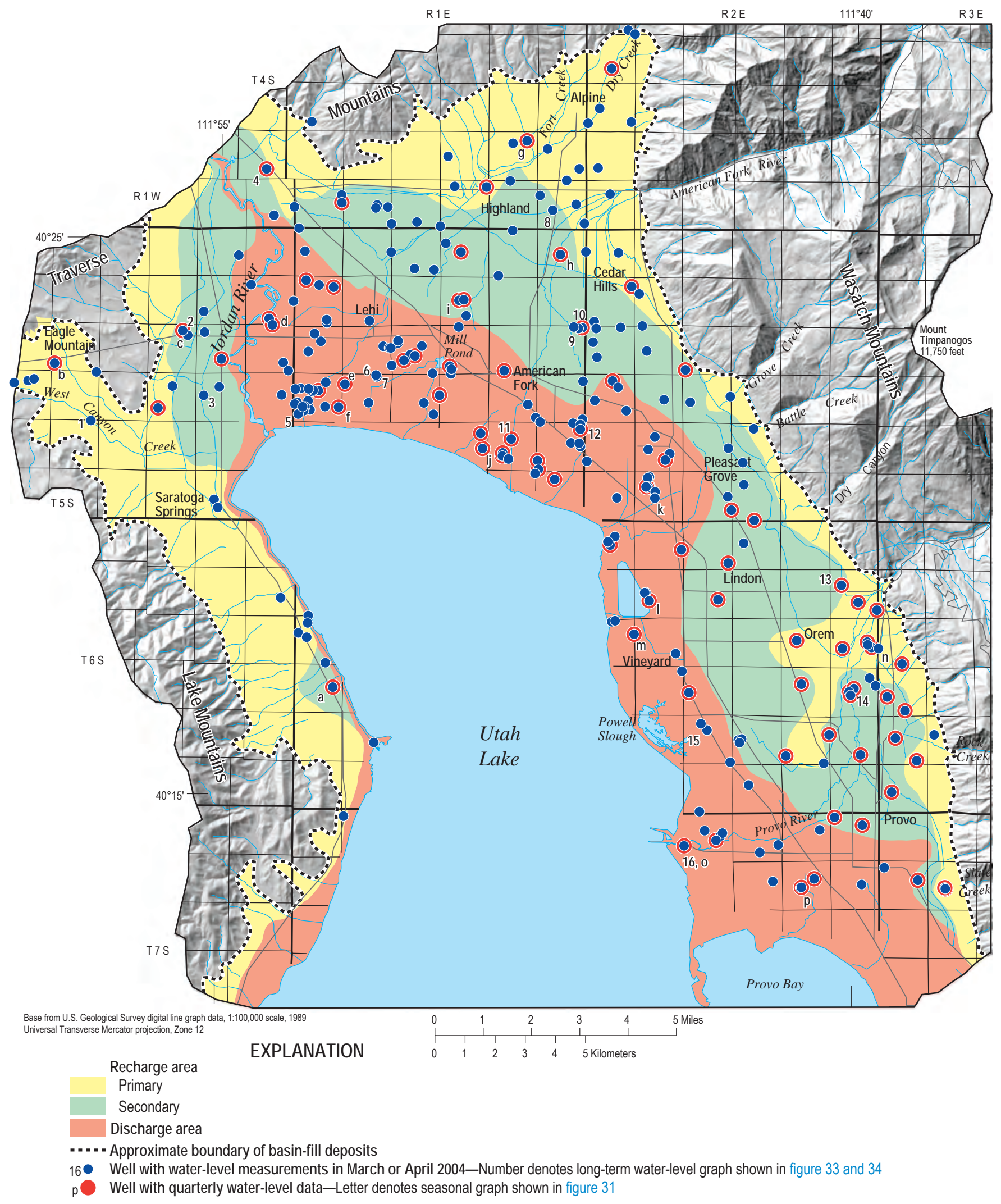

Figure 25. Location of wells where water levels were measured in March-April 2004 and then seasonally to June 2005 in northern Utah Valley, Utah. 
small mountain-front streams. Overall, the flow patterns determined from potentiometric contours and associated hydraulic gradients in 2004 are similar to contours delineated by Clark and Appel (1985, fig. 23), even though water levels are about $10 \mathrm{ft}$ lower in 2004 than those measured during 1981-82.

\section{Combined Pre-Lake Bonneville Unconfined Aquifer and Deep Pleistocene Confined Aquifer}

The potentiometric surface of the combined PLB and DP aquifers was interpolated by using water levels from 55 wells completed in the confined DP aquifer and 37 wells completed in the unconfined PLB aquifer along the mountain front (fig. 27). The unconfined PLB and confined DP aquifers are represented as one continuous unit because of the aereal extent and increased number of wells when combined. Water-level gradients range from about $0.0009(5 \mathrm{ft} / \mathrm{mi})$ on the Highland Bench below the mouth of American Fork Canyon to about $0.009(50 \mathrm{ft} / \mathrm{mi})$ near where Dry Creek enters the valley and flows onto the basin-fill deposits. The hydraulic gradient from where Dry Creek enters the valley to where it reaches Utah Lake is about $0.002(11 \mathrm{ft} / \mathrm{mi})$. Gradients are generally steeper near the mouths of canyons, where recharge is occurring and aquifer thickness and permeability is greater than in the valley lowlands. Gradients begin to decrease as the distance from the canyon mouth and mountain block increases. Gradients in the lower parts of the valley to Utah Lake generally are in the range of $0.002(11 \mathrm{ft} / \mathrm{mi})$ to $0.003(16 \mathrm{ft} / \mathrm{mi})$.

Ground-water flow in the combined PLB and DP aquifers is parallel to or oblique to the mountain front in areas where recharge is limited and substantially less than recharge occurring at or near the canyon mouths, such as south of American Fork Canyon and north of Provo Canyon. Water levels in the PLB and DP aquifers were generally higher than water levels measured in the SP aquifer in 2004. An exception is the area surrounding Provo, which may be attributed to seepage from the Provo River as a predominant recharge source in the valley compared to subsurface inflow from the mountain block in the area. Additionally, the confining clay units appear to extend closer to the mountain front where the Provo River has both gaining and losing reaches within the primary recharge area.

Water levels measured in the SP, PLB, and DP aquifers in 2004 generally were less than water levels measured in 1981, which likely is a result of a regional drought beginning in 1999. In addition, many irrigation wells completed in the SP, PLB, and DP aquifers may have been used to supplement inadequate surface-water flows for crop irrigation during the regional drought period, thereby increasing withdrawals from the aquifers. The change in potentiometric-surface altitude for the SP aquifer may also be the result of reduced seepage from irrigation as more agricultural land has been converted to commercial and residential land.

\section{Quaternary/Tertiary and Western Unconsolidated Aquifers}

The potentiometric surface of the QT aquifer, including water levels measured in wells completed in the WU aquifer west of Utah Lake and the Jordan River, was interpolated by using water-level measurements made during March 2004 in 31 wells completed in the QT aquifer and 21 wells completed in the WU aquifer (fig. 28). Hydraulic gradients in the QT aquifer east of the Jordan River range from 0.002 to 0.005 (11 to $26 \mathrm{ft} / \mathrm{mi}$ ). Flow direction and potentiometric surfaces are similar to those of the combined PLB and DP aquifer. Near the valley lowlands and west of the Jordan River, water-level altitudes are generally about $4,500 \mathrm{ft}$.

Water levels in the WU aquifer from the Cedar Pass area down into the valley near the west side of Utah Lake vary greatly with increasing altitude and distance from the valley lowlands. Water-level altitudes ranged from about 4,485 to $4,828 \mathrm{ft}$ during March 2004, resulting in a relatively steep hydraulic gradient of $0.018(100 \mathrm{ft} / \mathrm{mi})$ for the area. Water levels in few wells were measured between Cedar Pass and the valley bottom and a large error may be associated with this calculated gradient.

\section{Bedrock Aquifer West of the Jordan River}

Ground-water flow into northern Utah Valley from Cedar Valley also occurs through highly fractured bedrock in the Cedar Pass area (fig. 9). The water-level altitude measured in a well completed in limestone bedrock in the Cedar Pass area was about 4,515 ft in March 2004, about $15 \mathrm{ft}$ higher than that of water levels measured in wells completed in both the bedrock and WU aquifers near Utah Lake and the Jordan River. This results in a relatively low hydraulic gradient of 0.0009 (5 $\mathrm{ft} / \mathrm{mi})$.

\section{Water-Level Fluctuations}

Water levels fluctuate in response to changes in groundwater recharge and discharge. These water-level fluctuations can occur on a variety of time scales including short-term durations (daily, monthly, yearly) and long-term durations (decadal). To evaluate short-term (yearly) fluctuations within the principal basin-fill aquifer, water levels were measured during March-April 2004 and March 2005 in 112 wells. In addition, water levels in a subset of these wells also were measured quarterly during June-July 2004 (56 wells), October 2004 (74 wells), December-January 2004-05 (56 wells), and June 2005 (53 wells) to evaluate seasonal changes. Long-term (decadal) fluctuations were assessed from water-level measurements completed in 110 wells measured during 1981-82 (Clark and Appel, 1985) and March 2004. 


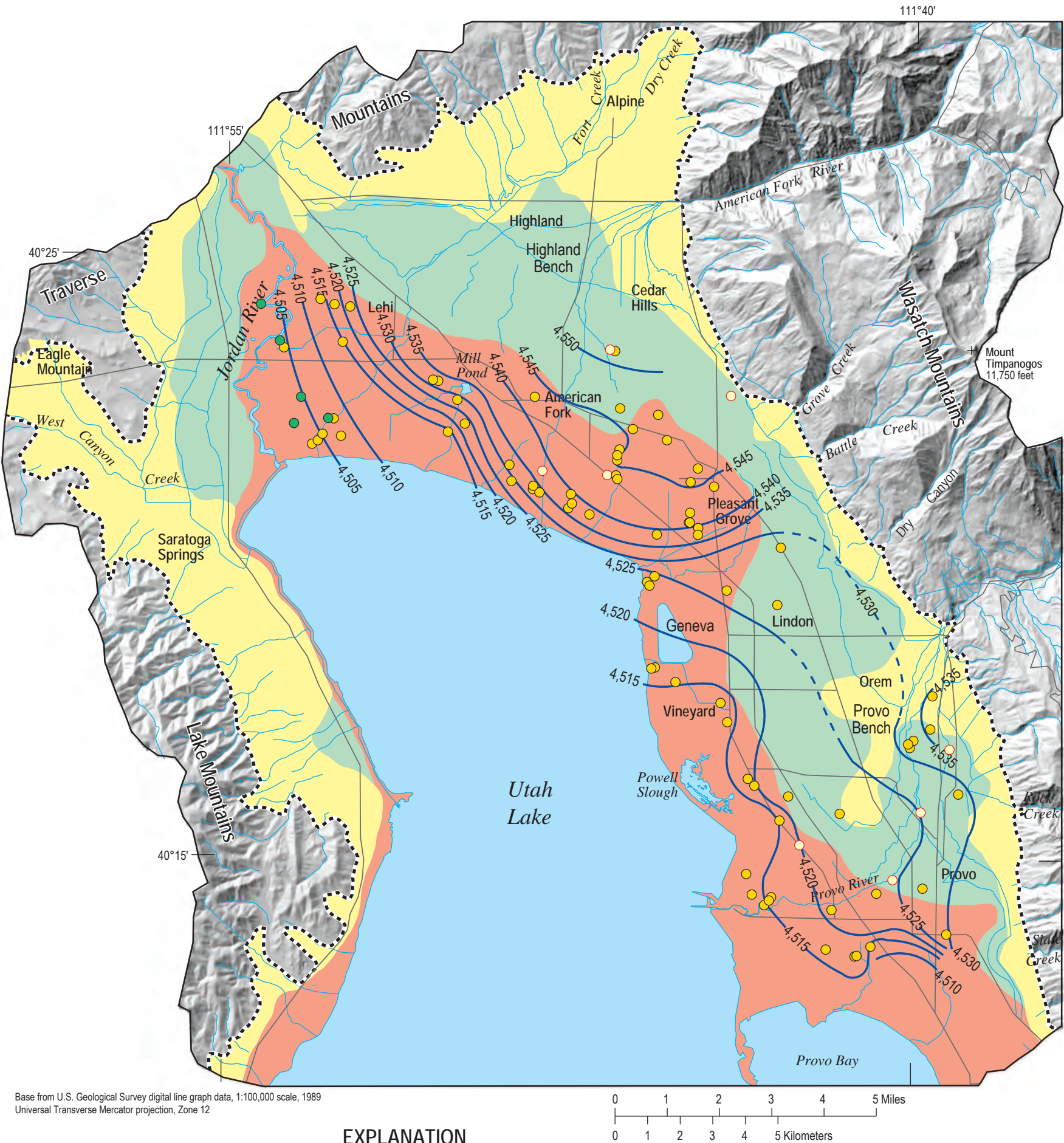

Recharge area

EXPLANATION

Primary

Well and associated aquifer used to determine potentiometric surface

O Shallow Pleistocene

O Shallow Pleistocene and deep Pleistocene

Discharge area

-... Approximate boundary of basin-fill deposits
$-4,510$ - Potentiometric contour-Shows altitude at which water level would

- Shallow Pleistocene, deep Pleistocene, and Quaternary/Tertiary

have stood in tightly cased wells. Dashed where approximately located. Contour interval 5 feet. Datum is NGVD 29

Figure 26. Potentiometric map for the shallow Pleistocene aquifer in northern Utah Valley, Utah, March-April 2004. 


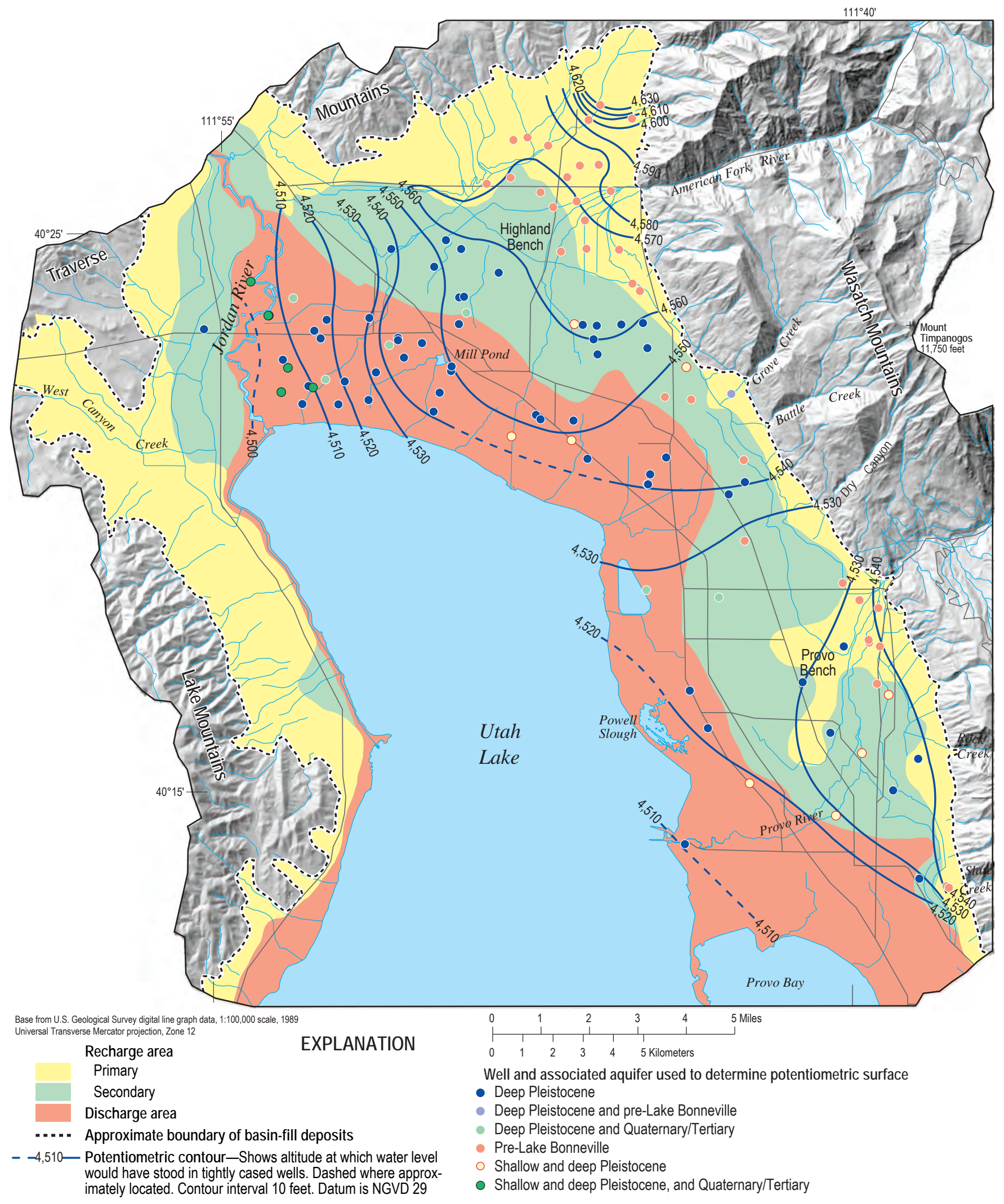

Figure 27. Potentiometric map for the combined pre-Lake Bonneville and deep Pleistocene aquifers in northern Utah Valley, Utah, March-April 2004. 


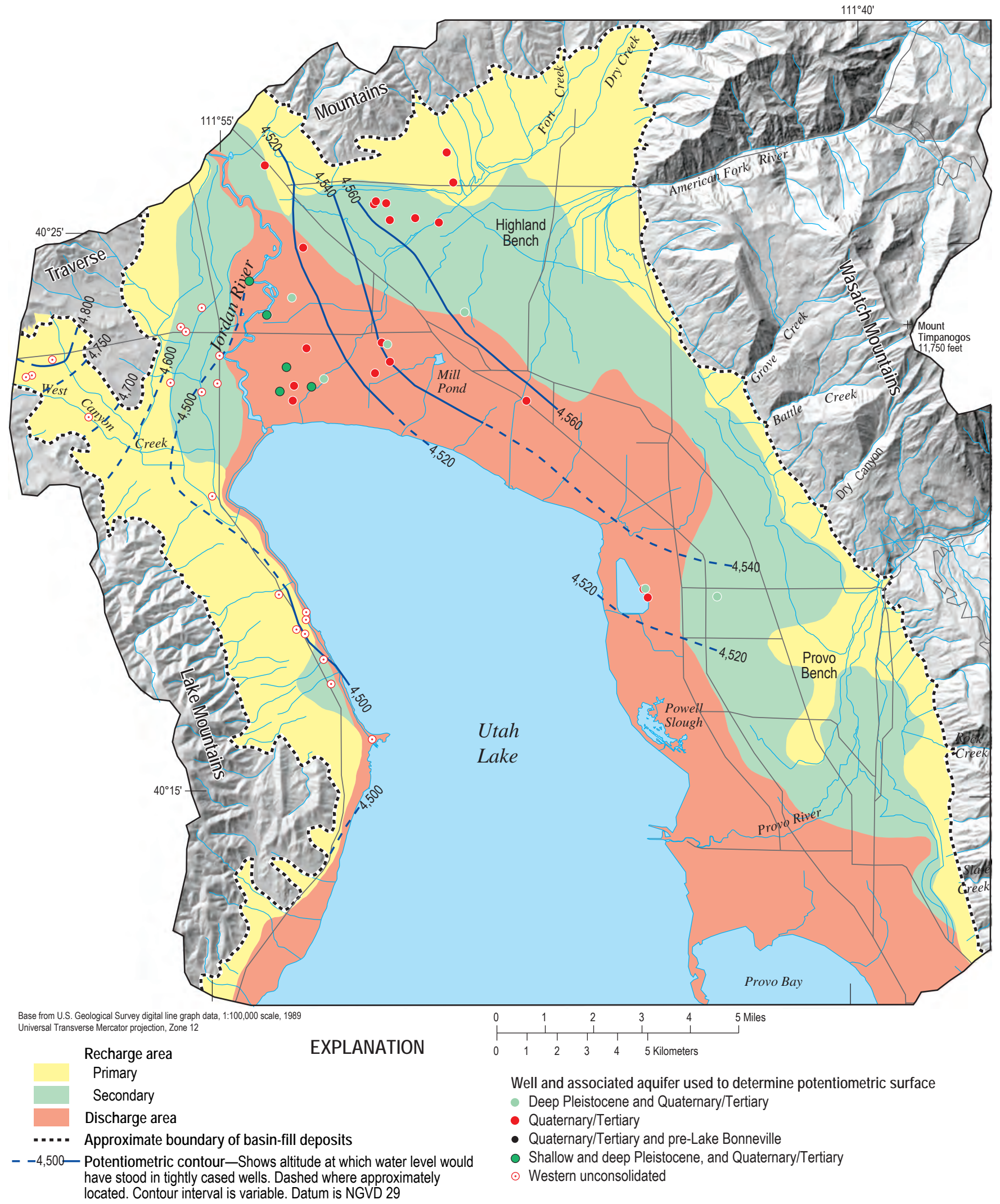

Figure 28. Potentiometric map for the Quaternary/Tertiary and Western unconsolidated aquifers in northern Utah Valley, Utah, MarchApril 2004. 


\section{Short-Term Fluctuations}

Water levels were measured repeatedly on a quarterly basis in at least 53 wells during the period March 2004 through June 2005 (appendix B). Water levels measured during 2004 are representative of less-than-normal recharge conditions resulting from drought conditions throughout the study area beginning in 1999. Precipitation in the study area was normal or greater than normal during 2005 relative to the 30 -year average precipitation. The relative increase in precipitation caused an increase in recharge to the principal basin-fill aquifer, as shown by increased water levels and longer duration of water-level rises in measured wells.

In general, water levels change seasonally as a result of a complex interrelation between ground-water pumping, precipitation, and runoff from the bedrock uplands. This is clearly illustrated by comparing the hydrograph of well (D-4-1)36abc-1 near Highland with the unregulated stream hydrograph of the American Fork River (fig. 29). Snowmelt runoff in the American Fork River during 2004 was less than normal, relative to the 30-year average, and occurred earlier than usual in the spring. In 2005, snowmelt runoff was close to the 30-year average and much greater than in 2004. The Highland well (fig. 29) illustrates the irrigation pumping and recovery signature superimposed with seasonal recharge from mountain runoff. From November to mid-March, 2003, the aquifer followed a typical pumping recovery curve. Then, from April to July, several precipitation-snowmelt events occurred, resulting in a double peak in the hydrograph. During this period, ground-water withdrawals increased in response to irrigation and municipal pumping, resulting in water-level declines during peak snowmelt runoff and through the summer months. The cycle restarted on October 2004, but this time, the recharge event in May-June was much larger, resulting in a much larger recharge peak in May through September. In fact, the recharge event was so much larger that the October recovery starts from a higher water level than in previous years, but the recovery pattern is much the same.

Although the quarterly hydrograph data (fig. 30) do not have the same resolution as in figure 29, study area wells show significant seasonality (pumping and recharge induced) and the effects of dry as compared to wet years (spring 2004 as compared to spring 2005). Measured water levels declined in most wells from March to June 2004, whereas average runoff during the same period in 2005 resulted in a rise in water levels (fig. 30). Water levels generally rose during October to December 2004, after the irrigation season ended and withdrawals from irrigation wells ceased. Water levels continued to

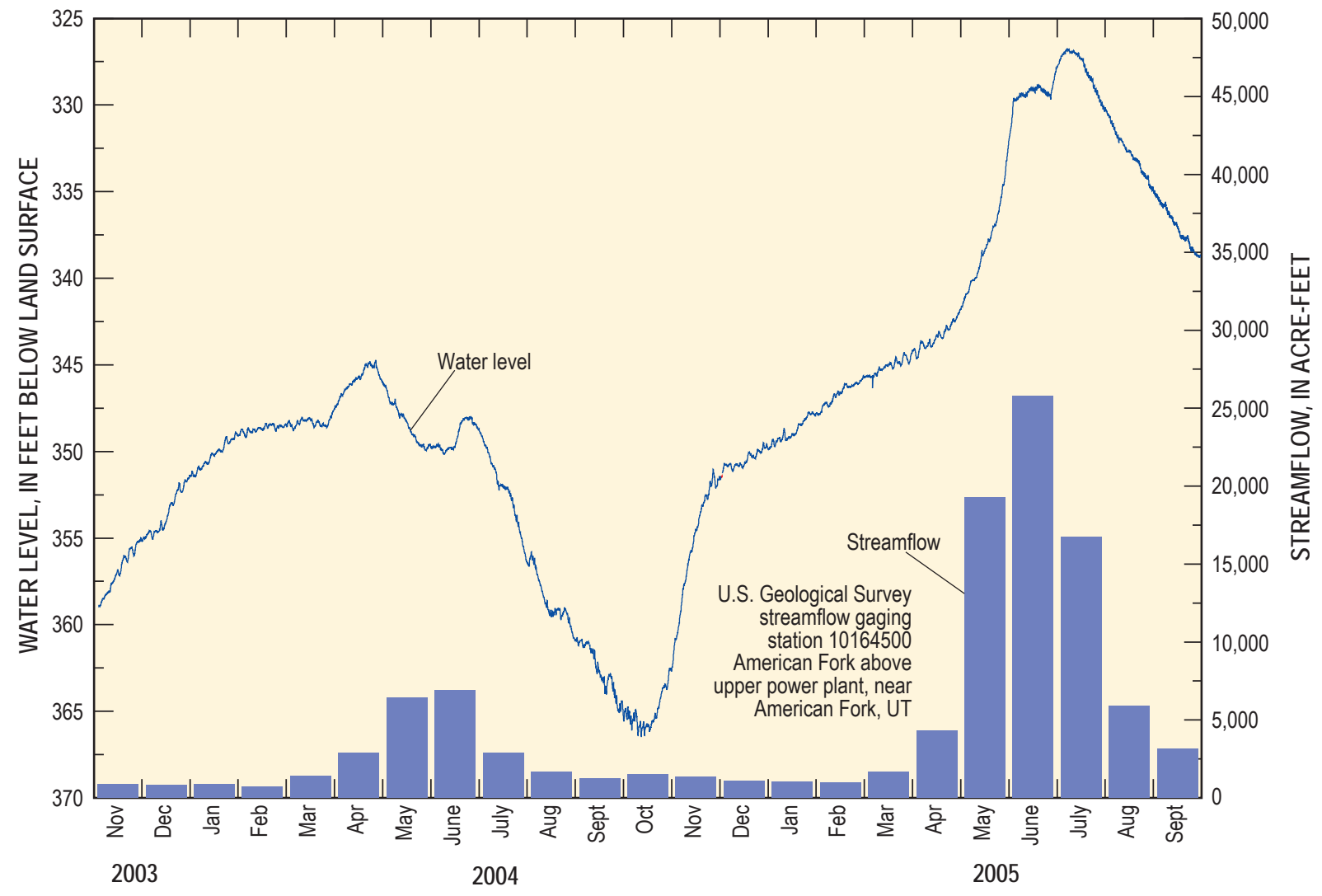

Figure 29. Water-level hydrograph at well (D-4-1)36abc-1 near Highland and monthly streamflow in the American Fork River, northern Utah Valley, Utah, November 2003 to September 2005. 


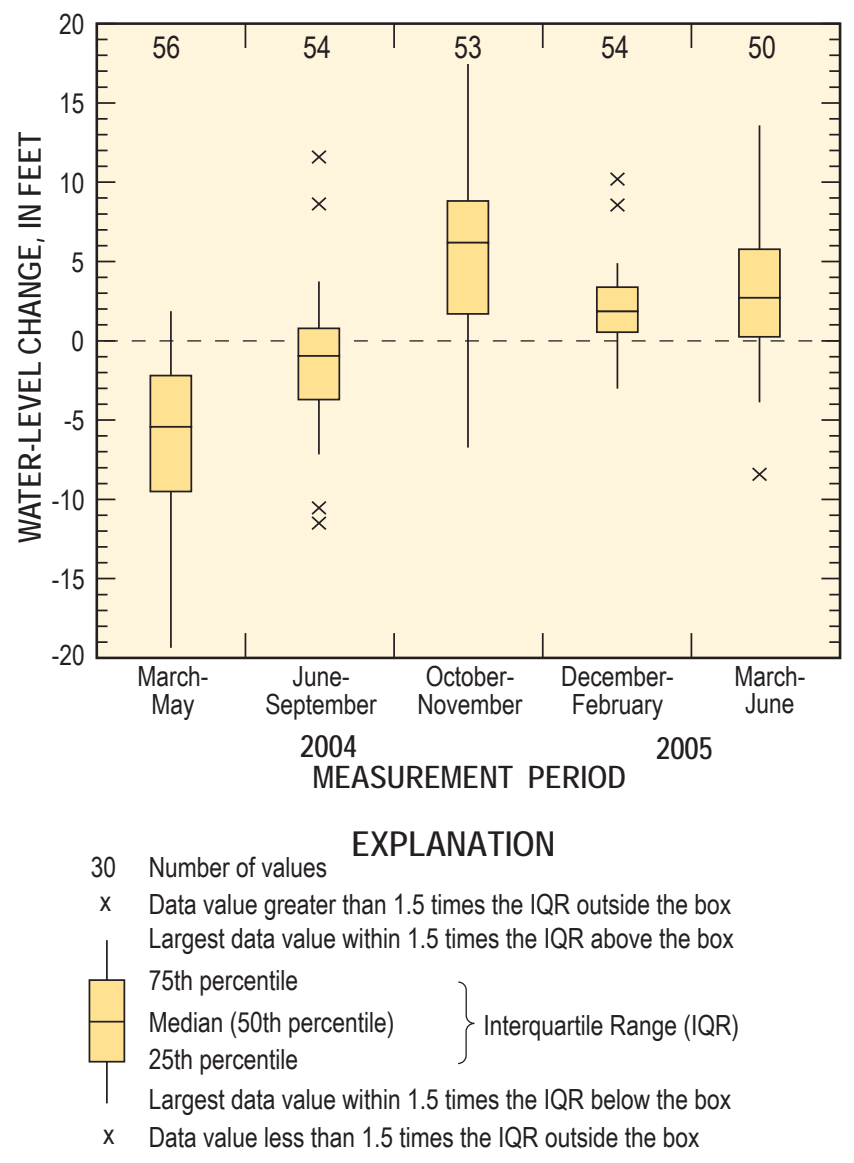

Figure 30. Quarterly water-level changes in wells in northern Utah Valley, Utah, March 2004-June 2005.

recover from December 2004 to March 2005 (fig. 30). Most of the water levels measured in wells east of the Jordan River and Utah Lake (fig. 31, hydrographs e-p) in March 2005 generally returned to or exceeded the previous year's level and showed a continued rise into June. Water levels in three wells west of the Jordan River (fig. 31, hydrographs b-d) declined from March to June 2005. This water-level decline occurred in both the unconfined and confined parts of the basin-fill aquifer and the cause is not known, but may be related to the recharge source area or to ground-water withdrawals in the area.

Water levels measured quarterly in adjacent wells (D-52)32bdb-2 and (D-5-2)32bdb-3, completed in the SP and DP aquifers, respectively, have the same overall trend, but the magnitude of change is greater in the well completed in the DP aquifer (fig. 31, hydrograph k). The vertical pressure gradient between the shallow (SP) and deep (DP) aquifer is upward during periods of recharge but a gradient reversal (downward) was detected during the summer caused by irrigation and municipal ground-water withdrawals. Locally, withdrawals from the DP aquifer are greater than from the SP aquifer.

\section{Long-Term Fluctuations}

Water levels in wells in northern Utah Valley declined from 1981 to 2004 (fig. 32) and are consistent with precipitation trends between the two periods (fig. 4). Generally, water levels in wells near the mountain front and near canyon mouths declined more than in wells in the valley lowlands. On average, water levels measured in 108 wells during both 1981-82 and 2004-05 declined by an average of $22.69 \mathrm{ft}$ for all aquifers. Water-level decreases in these wells ranged from about 0.33 to $108.46 \mathrm{ft}$ (table 18). The largest decline in measured water level of $108.46 \mathrm{ft}$ occurred in well (D-42)19dda-1, a relatively deep well completed in the PLB aquifer near Alpine and the mountain front, as would be expected during drought conditions. Water-level changes in the confined basin-fill aquifers (SP, DP, QT, and WU) were less pronounced than those in the unconfined PLB aquifer. Water-level changes in the SP aquifer ranged from -7.00 to $-42.88 \mathrm{ft}$, with an average decline of $-16.10 \mathrm{ft}$. Water-level changes in the DP aquifer had the greatest range ( -4.45 to $-58.32 \mathrm{ft}$ ) and the greatest average decline $(-25.66 \mathrm{ft})$. Water-level changes in the QT aquifer, including wells measured in the WU aquifer, ranged from about -2.9 to $-38.1 \mathrm{ft}$ with an average decrease of about $-22.3 \mathrm{ft}$.

Water levels reached a maximum in most wells during 1984-85, which was a period of greater-than-average precipi-

Table 18. Summary of water-level changes in wells measured during 1981 and 2004 in northern Utah Valley, Utah.

[All values are in feet]

\begin{tabular}{lccrr}
\hline \multicolumn{1}{c}{ Aquifer } & Number of wells & & \multicolumn{2}{c}{ Water-level change } \\
\cline { 3 - 5 } & measured & Minimum & \multicolumn{1}{c}{ Mean } & Maximum \\
\hline Lake Bonneville (LB) & 5 & -0.33 & -2.51 & -5.89 \\
Pre-Lake Bonneville (PLB) & 19 & -14.14 & -38.29 & -108.46 \\
Shallow Pleistocene (SP) & 35 & -7.00 & -16.10 & -42.88 \\
Deep Pleistocene (DP) & 24 & -4.45 & -25.66 & -58.32 \\
Quaternary/Tertiary (QT) & 11 & -14.89 & -25.79 & -38.13 \\
Western unconsolidated (WU) & 2 & -2.95 & -3.27 & -3.58 \\
Bedrock (B) & 2 & 6.50 & -3.80 & -14.10 \\
Unknown or mixed & 12 & -2.50 & -20.02 & -10 \\
All wells in basin-fill aquifers & 108 & -.33 & -22.69 & -108.46 \\
\hline
\end{tabular}



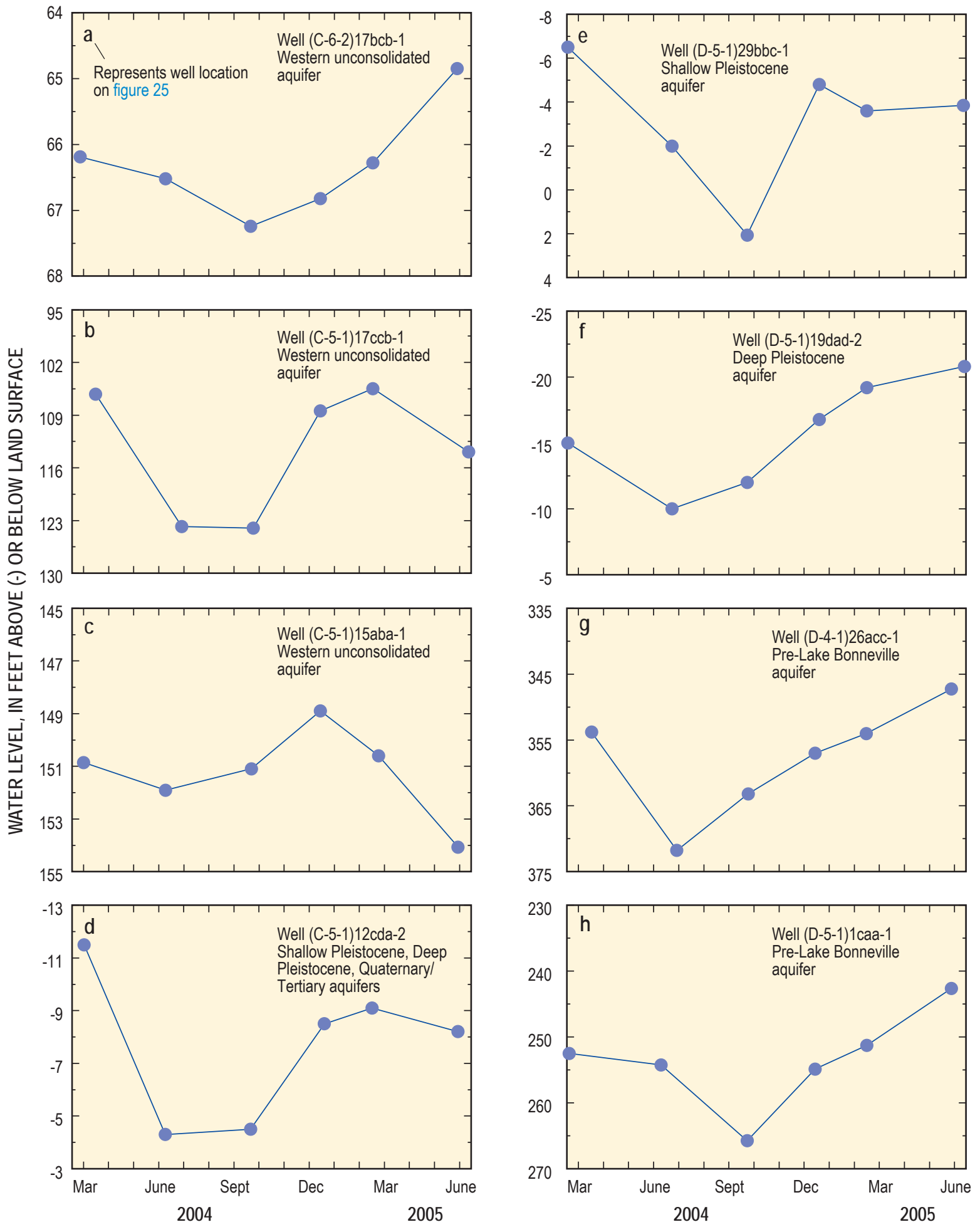

Figure 31. Quarterly water-level changes in selected wells in northern Utah Valley, Utah, March 2004-June 2005. 

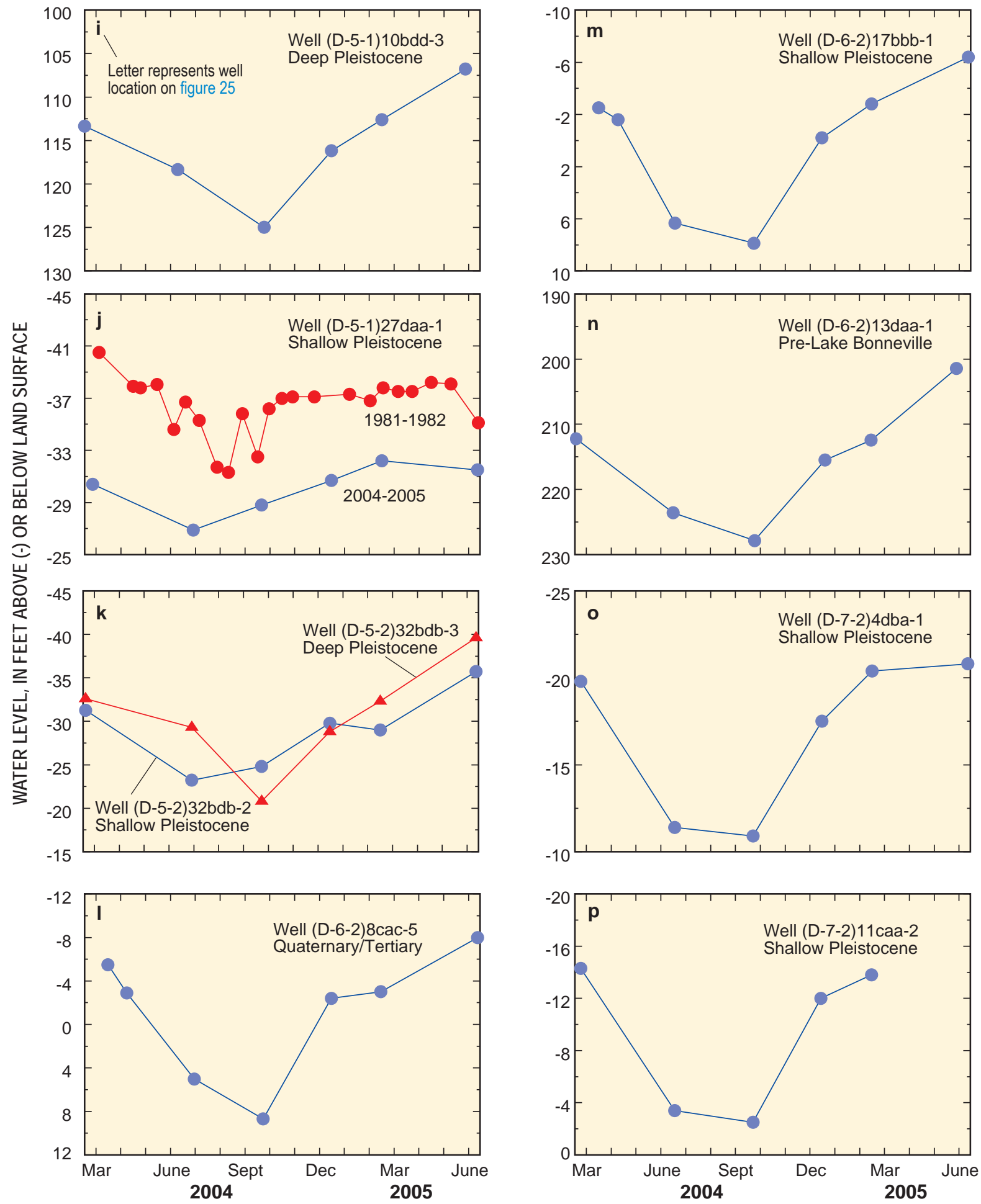

Figure 31. Quarterly water-level changes in selected wells in northern Utah Valley, Utah, March 2004-June 2005—Continued. 


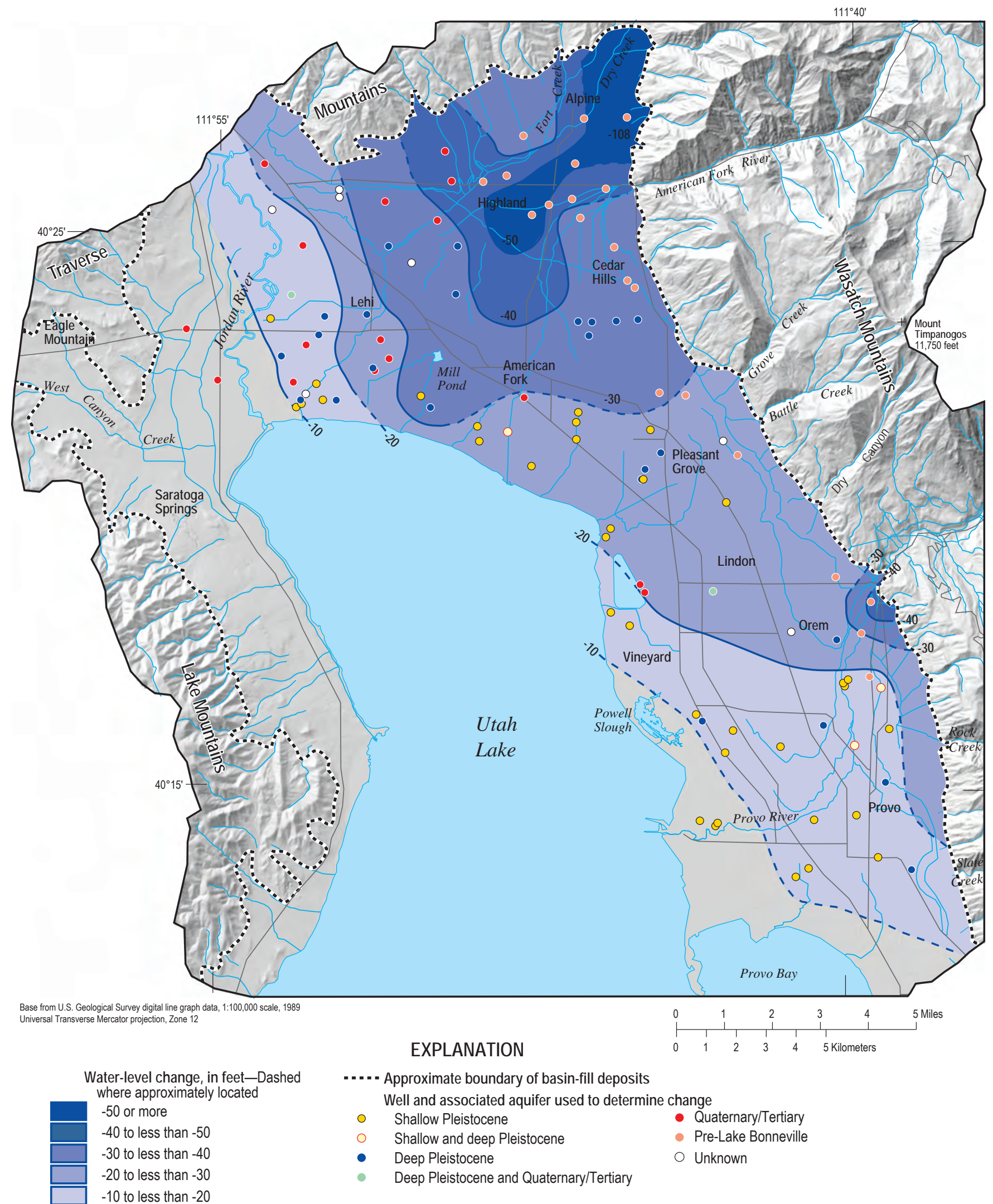

Figure 32. Generalized water-level change in the principal basin-fill aquifer of northern Utah Valley, Utah, $1981-2004$. 
tation throughout the study area (fig. 33, hydrographs 4-12). Below-average precipitation during the late 1980s and early 1990s caused water levels to decline. A return to near-average climatic conditions during the mid- to late- 1990s caused water levels to rise with the relative increase in precipitation. A severe regional drought starting in 1999 and continuing through 2004 resulted in substantial declines in water levels after 1999.
Long-term water-level fluctuations measured in adjacent wells (D-5-1)20aba-1 completed in the QT aquifer and (D-51)20aba-2 completed in the DP aquifer indicate the same overall trend, but the water levels were higher in the QT aquifer as compared to the DP aquifer (fig. 33, hydrographs 6 and 7). The magnitude of water-level declines within the QT aquifer was greater during periods of less-than-average precipitation relative to the DP aquifer. The upward gradient between the deeper QT aquifer and the shallower DP aquifer at this site

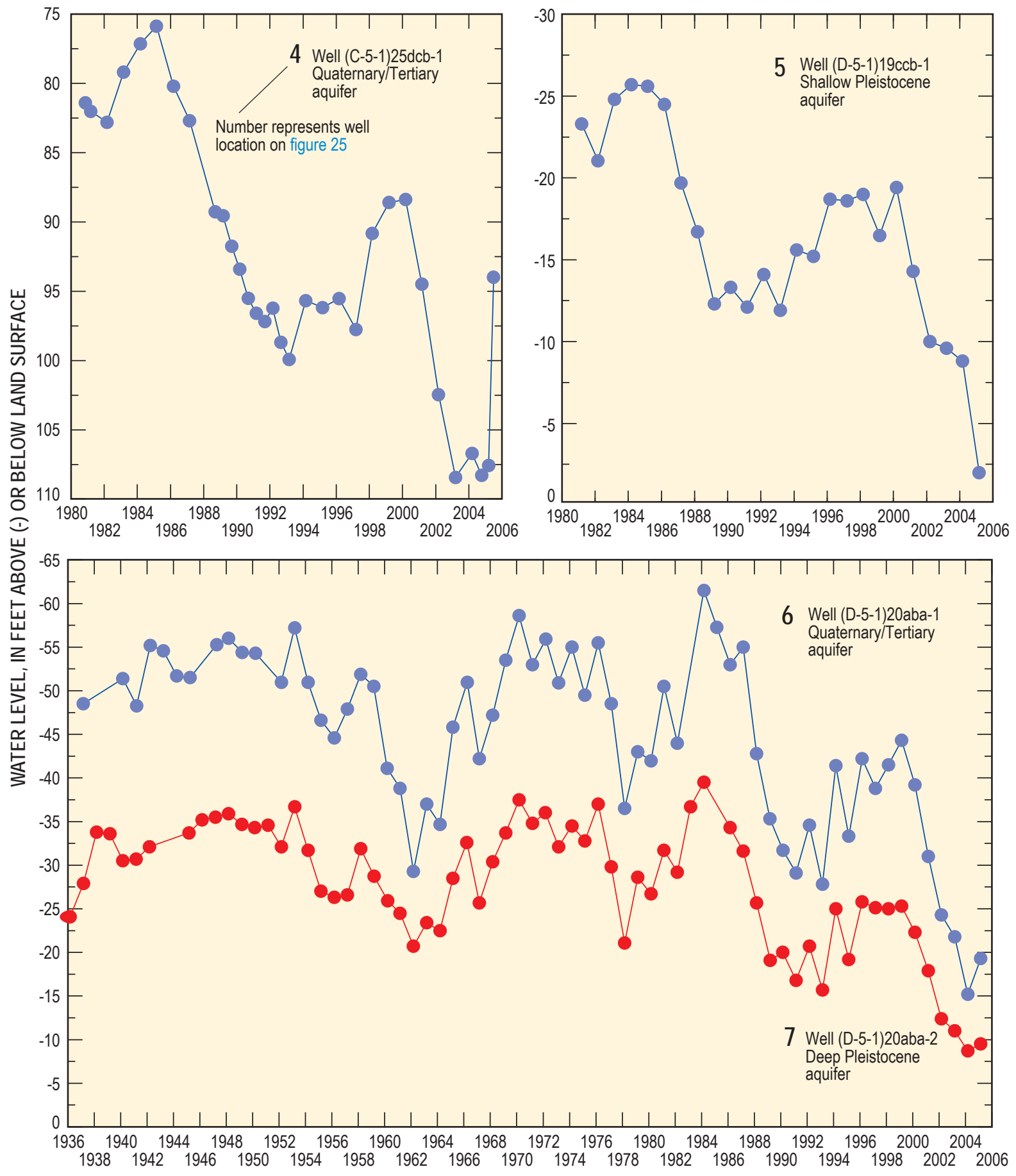

Figure 33. Long-term hydrographs displaying multi-year trends and fluctuations in wells in northern Utah Valley, Utah, 1936-2005. 


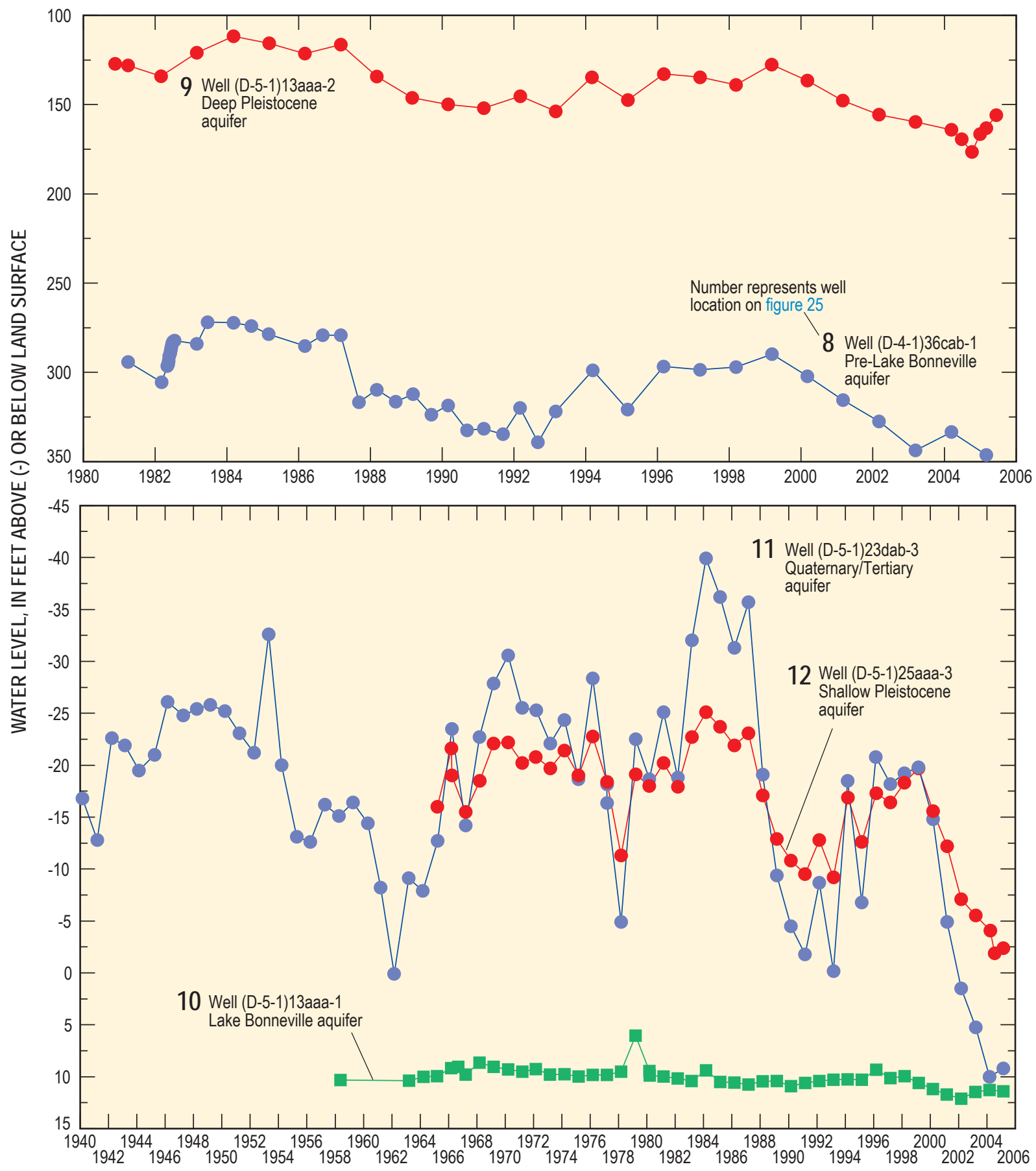

Figure 33. Long-term hydrographs displaying multi-year trends and fluctuations in wells in northern Utah Valley, Utah, 1936-2005-Continued.

decreased during the drought period of 1999-2004 relative to the past 70 years.

Long-term water-level records for wells in the western part of the study area are limited because of the lack of wells. Water-level fluctuations in two wells completed in the WU basin-fill aquifer, west of the Jordan River, illustrate the same declining trend as other wells in the valley (fig. 34, hydrographs 2 and 3). Well (C-5-1)20ddc-1 (fig. 34, hydrograph 1) is completed in both the WU basin-fill aquifer and the limestone bedrock aquifer near the Cedar Pass area. The well has a water-level record dating back to 1965 and is the only well in the area completed in the bedrock with a long-term record. This well was the only well in the study area with a rising water-level trend during 1999 to 2004. The reason for the rise is not known but is likely associated with connection to the limestone bedrock aquifer. 


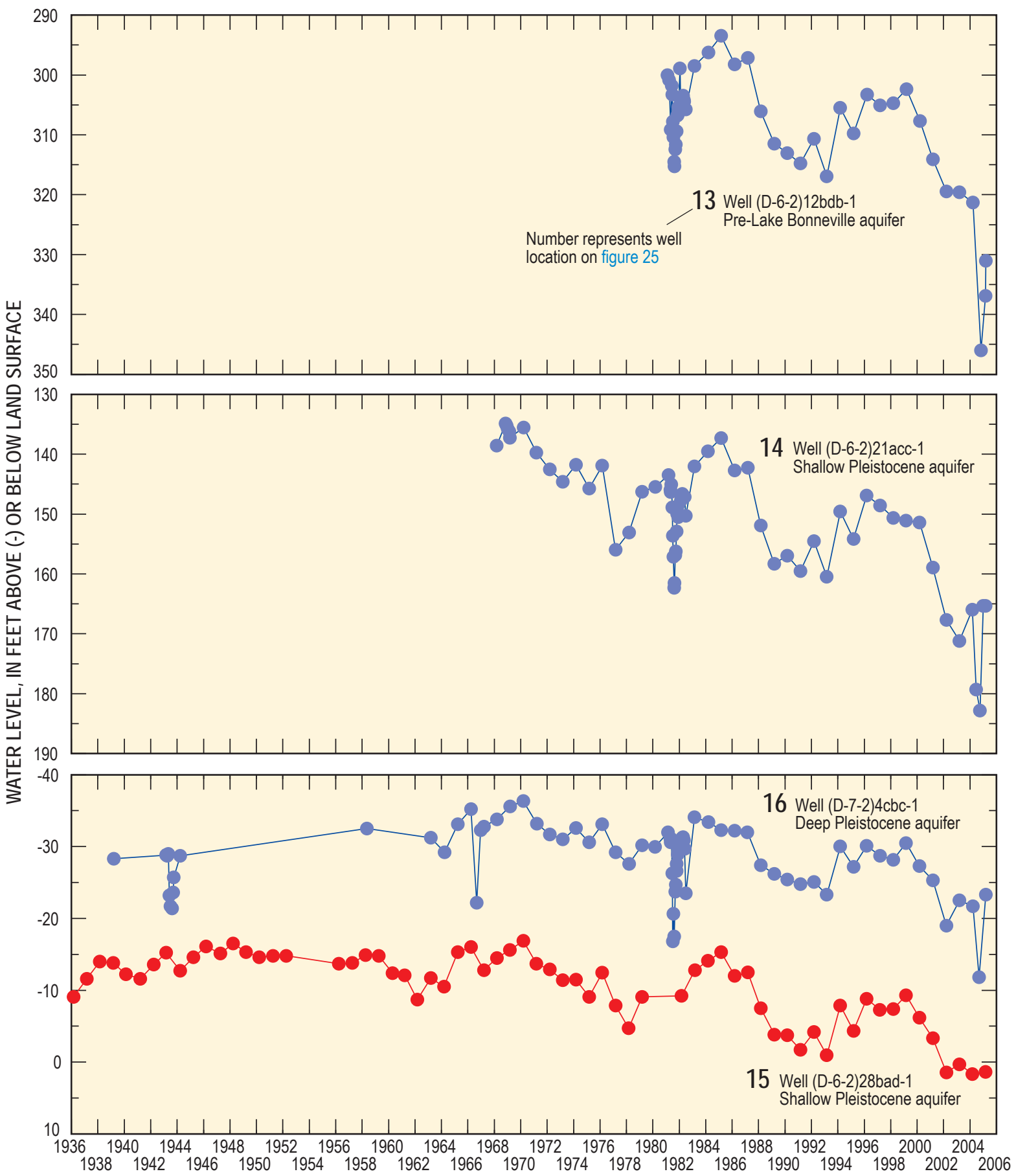

Figure 33. Long-term hydrographs displaying multi-year trends and fluctuations in wells in northern Utah Valley, Utah, 1936-2005-Continued. 

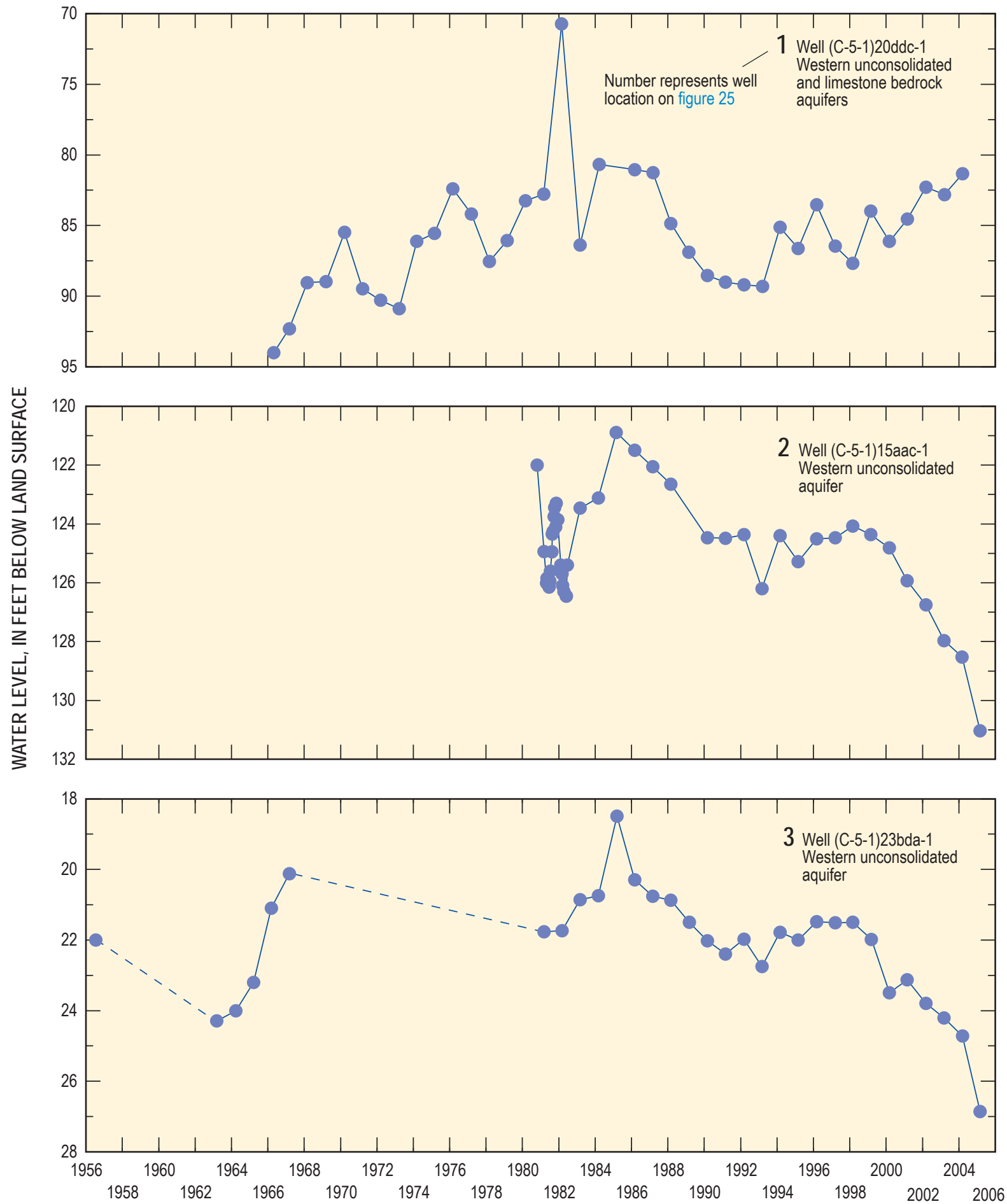

Figure 34. Long-term hydrographs displaying multi-year trends and fluctuations in wells west of the Jordan River in northern Utah Valley, Utah, 1956-2005. 


\section{Water Chemistry and Physical Properties}

Water samples were collected from 36 wells and springs throughout the study area during May 2003 to August 2005 (table 19 and fig. 35). Sampling sites were selected to target specific aquifers at multiple locations along likely groundwater flowpaths that generally follow the major river drainage basins from the mountain front down to the valley bottom.
Nested wells or wells located in the same general area, but completed at different intervals, also were targeted to evaluate the different aquifers at depth in the same vicinity. In some cases, distinct intervals could not be attained and some water samples represent water chemistry that may be a composite of more than one aquifer contributing to the same well.

At each location, physical properties, including water temperature, specific conductance, $\mathrm{pH}$, and dissolved-oxygen concentration, were measured prior to collecting water samples. Water samples collected from 34 wells (fig. 35) were

Table 19. Physical characteristics of 36 wells and springs sampled in northern Utah Valley, Utah, 2003-05.

[Sample identifier: see figure 35 for the location of sites sampled as part of this study. Well identifier: see front of report for an explanation of the well-numbering system used in Utah. Theoretical flowpath: shown on figure 35. Contributing aquifer: LB, Lake Bonneville; PLB, pre-Lake Bonneville; SP, shallow Pleistocene; DP, deep Pleistocene; QT, Quaternary/Tertiary; WU, Western unconsolidated; B, bedrock. All values are in feet. Abbreviations: -, no data or not applicable. ]

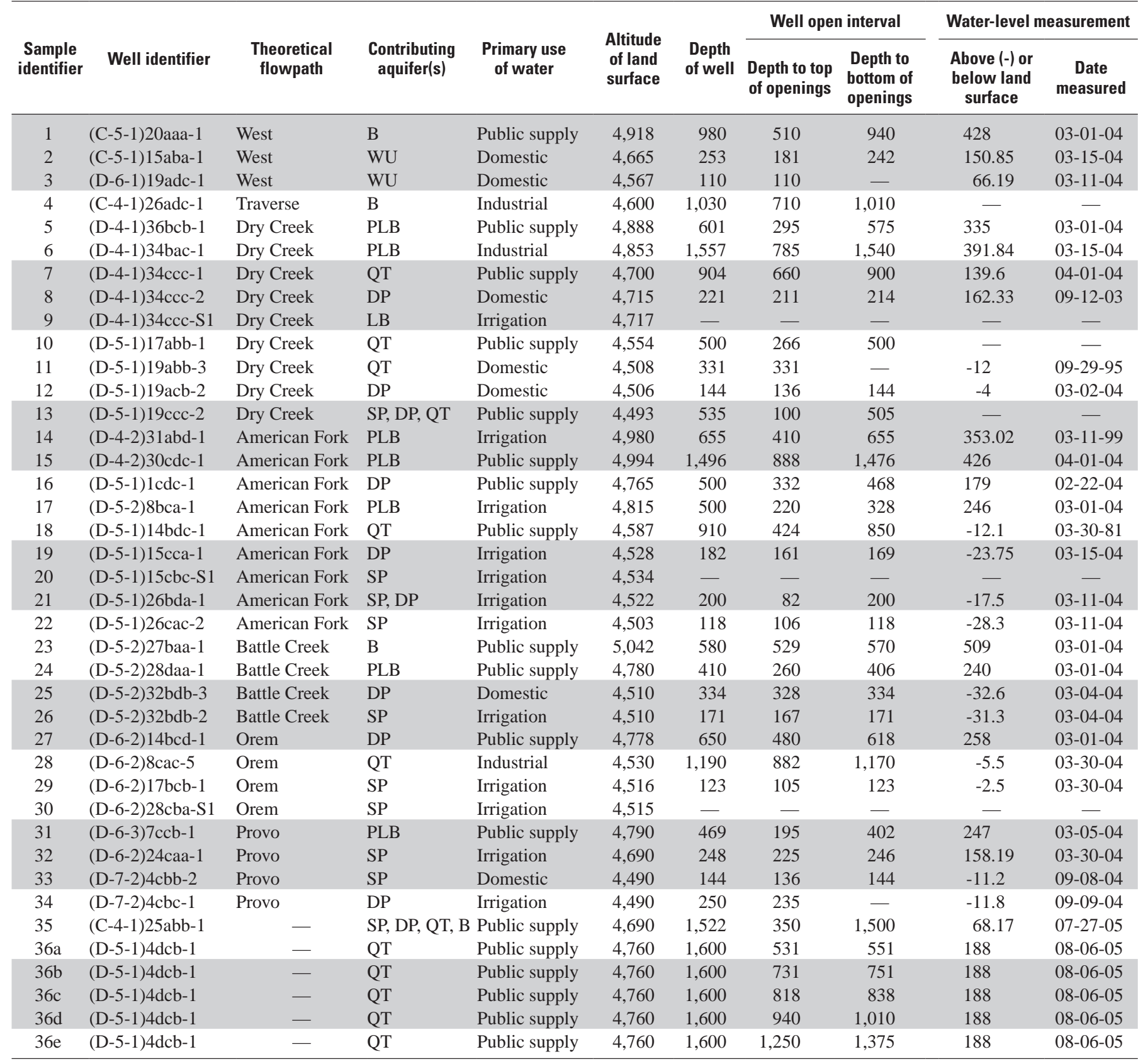




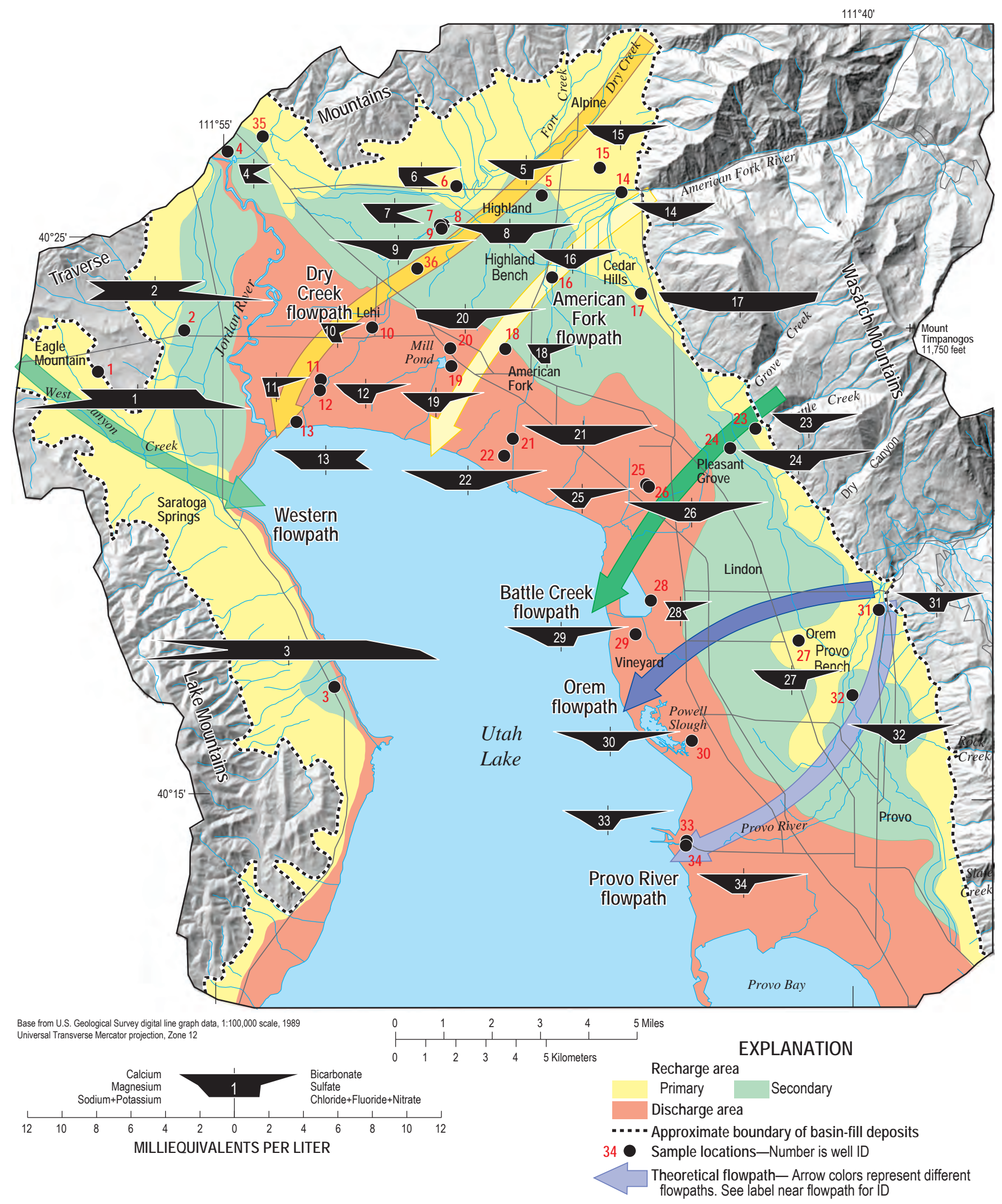

Figure 35. Location of sampled sites and major-ion composition of ground water in northern Utah Valley, Utah, $2003-04$. 
analyzed for dissolved major ions, dissolved nutrients, stable isotopes, dissolved gases, and tritium/helium-3 concentrations in order to aid in determining water sources and ground-water flowpaths within the principal basin-fill aquifer. In addition, dissolved gases and tritium/helium-3 concentrations were analyzed from samples collected during the well development and aquifer testing process at two newly drilled deep (greater than 1,000 ft) public-supply wells (sample identifier 35 and 36). Water from well 36 was sampled at five distinct and isolated vertical intervals (table 19, samples 36a-e).

\section{Methods}

Water from wells was collected either by pumping with an existing pump, or by using the artesian pressure to allow the well to flow freely. Before sampling, field parameters were monitored continuously and allowed to stabilize during a purge process. Samples were collected from a sample tap or hose bib as close to the wellhead as possible and before the water enters any storage or pressure tanks. Water samples were collected from springs by inserting a 2-in.-diameter polyvinyl chloride casing fitted with a 3 -ft-long section of screen with a conical end point into a spring orifice as far as it would go without using excessive force. The top of the casing had to be positioned so that water could overflow and purge the temporary well for 24 hours before field parameters and samples were collected. Samples were collected using a peristaltic pump with tubing inserted into the screened interval of the temporary well.

Samples to be analyzed for dissolved major ions and nutrients were filtered with a 0.45 -micrometer $(\mu \mathrm{m})$ filter. The cation subsample was preserved with nitric acid. Water samples collected to be analyzed for dissolved major ions and nutrients were analyzed by the USGS National Water Quality Laboratory in Denver, Colorado. Samples to be analyzed for stable isotopes were collected in glass containers, sealed with polyseal caps leaving no air space, and analyzed by the USGS Stable Isotope Laboratory in Reston, Virginia. Tritium/helium-3 samples were collected in 1-liter polyethylene bottles and sealed with polyseal caps leaving no air space in the container. Tritium/helium-3 samples were analyzed by the University of Utah Dissolved Gas Service Center in Salt Lake City, Utah.

Dissolved-gas samples were collected by using either water samples in copper tubes as described by Stute and Schlosser (2001) or as gas samples with diffusion samplers as described by Sheldon (2002). If a well fitted with a pump was not capable of being pumped continuously for 24 hours, the copper tube method was used. The copper tube method consists of attaching a 30-in.-long section of 3/8-in.-diameter copper tubing to a sampling port at the wellhead, allowing the tube to flush with well water, then sealing both ends. The diffusion sampler method was used at wells and springs where uninterrupted flow was possible. The diffusion sampler is constructed of 1/8-in.-diameter copper tubing and a semi- permeable gas diffusion membrane. The sampler was placed directly into the well or spring, or fitted in an airtight chamber connected to a discharge point at the wellhead allowing water to flow through the chamber and past the membrane. After about 24 hours, when the diffusion sampler had equilibrated to the sample water, the sampler was removed from the well or spring and immediately sealed. Dissolved-gas concentrations were analyzed by the University of Utah Dissolved Gas Service Center with both quadrupole and sector-field mass spectrometers. The analysis provides the relative mole fractions of gasses dissolved in a sample. The dissolved-gas concentrations are then calculated based on Henry's Law relations using field measurements of total dissolved-gas pressure and water temperature.

\section{Major lons and Nutrients}

In northern Utah Valley, dissolved major-ion compositions generally fall into two categories, depending on whether the water sample was collected to the east or west of Utah Lake/Jordan River. Thirty-one ground-water samples were collected east of the Jordan River and consist mostly of calciummagnesium-bicarbonate type waters (fig. 36). Three samples were collected west of the Jordan River and consist of mixedtype waters with sodium, calcium, chloride, sulfate, and bicarbonate as the dominant ions. The samples collected west of the Jordan River also have higher dissolved-solids concentrations (783 to $1,590 \mathrm{mg} / \mathrm{L}$ ) than samples collected east of the Jordan River (141 to $491 \mathrm{mg} / \mathrm{L}$ ) (table 20). One additional sample collected on the east side of the valley, sample 17, was reported to have a dissolved-solids concentration of $778 \mathrm{mg} / \mathrm{L}$, considerably higher than that of other nearby samples collected from within the same aquifer. The sample was collected from a 500-ft-deep irrigation supply well situated near the mountain front and finished in the PLB aquifer where the depth to water was $246 \mathrm{ft}$ below land surface. Land use surrounding the well includes irrigated agriculture and stock watering with multiple irrigation canals traversing the land surface upgradient of the well. This sample also had the highest nitrate concentration $(4.4 \mathrm{mg} / \mathrm{L})$ of all the samples collected during the study. The anomalous concentrations and relative location to agricultural activities indicate that the sample is likely representative of local surface conditions with the likelihood that the sample was cross contaminated or represents water that has leaked down along the borehole from the surface and not representative of regional aquifer properties.

Water samples that were collected from wells and springs in the same contributing aquifer and along the same flowpath generally had similar dissolved-solids concentrations. Dissolved-solids concentrations in samples collected from different contributing aquifers generally decreased with increased depth into the aquifers (fig. 37). Dissolved-solids concentrations on the eastern side of the valley had the highest median value of $332 \mathrm{mg} / \mathrm{L}$ in samples collected from the SP aquifer with values ranging from 312 to $491 \mathrm{mg} / \mathrm{L}$. Dissolved- 


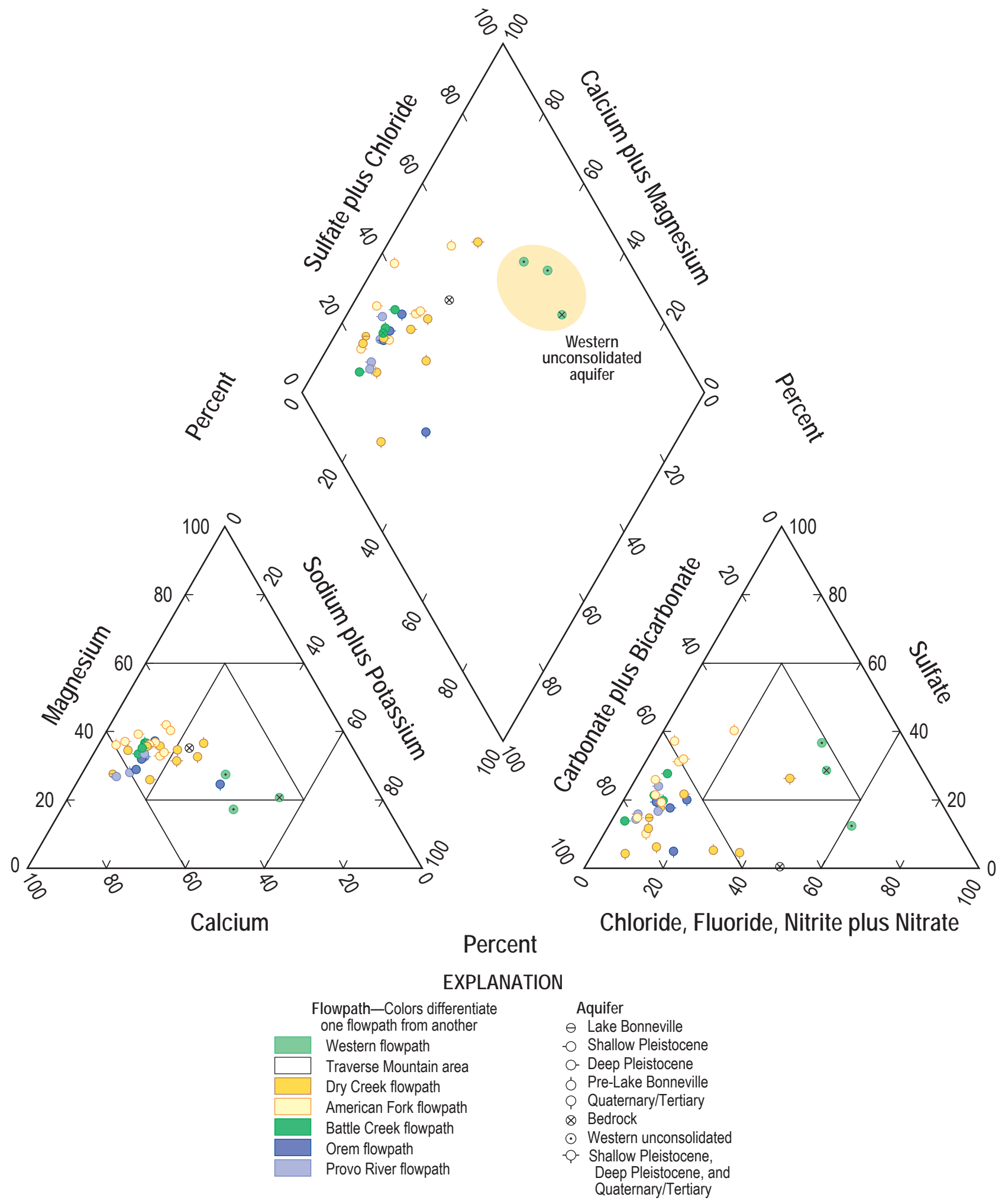

Figure 36. Major-ion composition of ground water sampled from 34 sites in northern Utah Valley, Utah, $2003-04$. 
Table 20. Physical properties and concentration of dissolved ions and nutrients in ground water, northern Utah Valley, Utah, 2003-05.

[Sample identifier: see figure 35 for the location of sites sampled as part of this study. A bbreviations: $\mathrm{mm} \mathrm{Hg}$, millimeters of mercury; ${ }^{\circ} \mathrm{C}$, degrees Celsius; $\mu \mathrm{S} /$ $\mathrm{cm}$, microsiemens per centimeter at 25 degrees Celsius; mg/L, milligrams per liter; $\mu \mathrm{g} / \mathrm{L}$, micrograms per liter; —, not analyzed; <, less than; e, estimated]

\begin{tabular}{|c|c|c|c|c|c|c|c|c|c|c|}
\hline \multirow[b]{2}{*}{$\begin{array}{l}\text { Sample } \\
\text { identifier }\end{array}$} & \multirow[b]{2}{*}{$\begin{array}{c}\text { Sample } \\
\text { date }\end{array}$} & \multirow[b]{2}{*}{$\begin{array}{c}\text { Sample } \\
\text { time }\end{array}$} & \multirow{2}{*}{$\begin{array}{c}\text { Air } \\
\text { pressure } \\
(\mathrm{mm} \mathrm{Hg})\end{array}$} & \multirow{2}{*}{$\begin{array}{l}\text { Dissolved- } \\
\text { gas pressure } \\
(\mathrm{mm} \mathrm{Hg})\end{array}$} & \multirow{2}{*}{$\begin{array}{c}\text { Air } \\
\text { temperature } \\
\text { ('Celsius) }\end{array}$} & \multirow{2}{*}{$\begin{array}{c}\text { Water tem- } \\
\text { perature } \\
\text { (등sius) }\end{array}$} & \multirow{2}{*}{$\begin{array}{c}\text { Specific } \\
\text { conductance } \\
(\mu \mathrm{S} / \mathrm{cm})\end{array}$} & \multirow{2}{*}{$\begin{array}{c}\text { pH } \\
\text { (standard } \\
\text { units) }\end{array}$} & \multicolumn{2}{|c|}{ Dissolved oxygen } \\
\hline & & & & & & & & & (mg/L) & $\begin{array}{c}\text { (percent } \\
\text { saturation) }\end{array}$ \\
\hline 1 & 06-04-03 & 1300 & 645 & - & 24.5 & 23.5 & 1,700 & 7.3 & 1 & 14 \\
\hline 2 & $08-11-04$ & 1100 & 651 & - & 28 & 15.6 & 1,380 & 7.2 & 10.1 & 118 \\
\hline 3 & $11-13-03$ & 1130 & 650 & - & 9.5 & 30.0 & 2,370 & 6.9 & 2.8 & 44 \\
\hline 4 & $05-12-03$ & 1300 & 649 & - & 22 & 23.0 & 290 & 8.8 & 2.7 & 37 \\
\hline 5 & $08-20-03$ & 1500 & 643 & 1,380 & - & 10.0 & 400 & 7.6 & 13.8 & 145 \\
\hline 6 & $07-27-04$ & 1045 & 640 & 841 & 26.5 & 20.8 & 435 & 7.5 & 5.8 & 77 \\
\hline 7 & 09-04-03 & 1100 & 650 & 832 & 26.5 & 17.5 & 520 & 7.5 & 5.9 & 73 \\
\hline 8 & $09-12-03$ & 1000 & 649 & 842 & 18 & 12.5 & 690 & 7.1 & 2.7 & 30 \\
\hline 9 & 09-16-03 & 1300 & 642 & 641 & 27 & 13.5 & 588 & 7.2 & 3.6 & 41 \\
\hline 10 & 09-08-04 & 1000 & 648 & 861 & 22 & 13.3 & 229 & 8 & 5.8 & 66 \\
\hline 11 & $09-12-03$ & 1100 & 654 & 795 & 25 & 14.0 & 210 & 7.9 & .9 & 10 \\
\hline 12 & 09-04-03 & 1430 & 654 & 869 & 33.5 & 12.0 & 375 & 7.7 & 3.5 & 38 \\
\hline 13 & 08-02-04 & 1315 & 647 & 711 & 29.5 & 14.7 & 821 & 7.4 & .5 & 6 \\
\hline 14 & $08-28-03$ & 1430 & 642 & 825 & 34 & 11.4 & 435 & 7.7 & 9 & 98 \\
\hline 15 & 09-16-03 & 1100 & 637 & 805 & 26 & 12.5 & 402 & 7.4 & 7.4 & 83 \\
\hline 16 & $07-20-04$ & 1200 & 644 & 979 & 26.5 & 9.6 & 443 & 7.4 & 9.9 & 103 \\
\hline 17 & $07-29-04$ & 1300 & 640 & 1,050 & - & 14.3 & 1,170 & 7.1 & 9.4 & 110 \\
\hline 18 & 07-20-04 & 0930 & 648 & 898 & 26 & 11.6 & 248 & 7.9 & 8.2 & 89 \\
\hline 19 & $07-28-04$ & 1245 & 648 & 1,020 & 32 & 10.7 & 438 & 7.5 & 9 & 96 \\
\hline 20 & $08-12-04$ & 1300 & 646 & 630 & 31 & 11.9 & 470 & 7 & 2.7 & 29 \\
\hline 21 & $08-16-04$ & 1200 & 650 & 795 & 28 & 11.7 & 782 & 7.2 & 1.8 & 19 \\
\hline 22 & 08-11-04 & 1300 & 651 & 805 & 30 & 11.6 & 820 & 7.2 & .2 & 0 \\
\hline 23 & 07-29-04 & 1045 & 635 & 1,770 & - & 15.2 & 484 & 7.4 & 13.3 & 160 \\
\hline 24 & 07-30-04 & 1245 & 640 & 770 & - & 12.4 & 718 & 7.1 & 8.1 & 91 \\
\hline 25 & $07-21-04$ & 1400 & 645 & 727 & 33.5 & 12.2 & 383 & 7.9 & .1 & 0 \\
\hline 26 & $07-21-04$ & 1330 & 646 & 832 & 33.5 & 11.4 & 726 & 7.3 & .1 & 1 \\
\hline 27 & 08-17-04 & 1100 & 644 & 821 & 28.5 & 15.7 & 525 & 7.4 & 5.9 & 70 \\
\hline 28 & $04-22-04$ & 1500 & 643 & 785 & 16 & 19.9 & 290 & 8 & .5 & 7 \\
\hline 29 & 04-23-04 & 1200 & 648 & 761 & 20 & 13.3 & 608 & 7.3 & 1.3 & 14 \\
\hline 30 & 08-13-04 & 1200 & 648 & 811 & 31 & 13.6 & 575 & 7.1 & 3.9 & 43 \\
\hline 31 & 08-16-04 & 1000 & 644 & 692 & 18.5 & 10.4 & 453 & 7.3 & 7.6 & 81 \\
\hline 32 & 08-24-04 & 1100 & 648 & - & 20 & 11.9 & 550 & 7.3 & 5.8 & 63 \\
\hline 33 & 09-08-04 & 1400 & 648 & 746 & 28 & 12.6 & 530 & 7.5 & .2 & 2 \\
\hline 34 & 09-09-04 & 1200 & 648 & 742 & 27.5 & 12.5 & 526 & 7.4 & .2 & 2 \\
\hline 35 & 07-27-05 & 1530 & 650 & - & - & 29.7 & 806 & 7.2 & .8 & 13 \\
\hline $36 \mathrm{a}$ & 08-06-05 & 1400 & 651 & - & - & 15.9 & 539 & 7.6 & 5.2 & - \\
\hline $36 \mathrm{~b}$ & $08-10-05$ & 0700 & 639 & - & - & 17.5 & 618 & 7.7 & 5.4 & 67 \\
\hline $36 c$ & $08-11-05$ & 0840 & 661 & - & - & 18.4 & 493 & 7.9 & 3.1 & 38 \\
\hline $36 \mathrm{~d}$ & $08-12-05$ & 2130 & 645 & - & - & 19.2 & 472 & 7.8 & 2.8 & 36 \\
\hline $36 \mathrm{e}$ & 08-14-05 & 0215 & - & - & - & 20.0 & 566 & 7.8 & 1.7 & 22 \\
\hline
\end{tabular}


Table 20. Physical properties and concentration of dissolved ions in ground water, northern Utah Valley, Utah, 2003-05-Continued.

[Sample identifier: see figure 35 for the location of sites sampled as part of this study. A bbreviations: $\mathrm{mm} \mathrm{Hg}$, millimeters of mercury; ${ }^{\circ} \mathrm{C}$, degrees Celsius; $\mu \mathrm{S} /$ $\mathrm{cm}$, microsiemens per centimeter at 25 degrees Celsius; mg/L, milligrams per liter; $\mu \mathrm{g} / \mathrm{L}$, micrograms per liter; —, not analyzed; <, less than; e, estimated]

\begin{tabular}{|c|c|c|c|c|c|c|c|c|c|c|}
\hline $\begin{array}{c}\text { Sample } \\
\text { identifier }\end{array}$ & $\begin{array}{l}\text { Sample } \\
\text { date }\end{array}$ & $\begin{array}{l}\text { Sample } \\
\text { time }\end{array}$ & $\begin{array}{c}\text { Alkalinity } \\
(\mathrm{mg} / \mathrm{L} \text { as } \\
\left.\mathrm{CaCO}_{3}\right)\end{array}$ & $\begin{array}{l}\text { Arsenic } \\
(\mu \mathrm{g} / \mathrm{L} \text { as } \\
\text { As) }\end{array}$ & $\begin{array}{c}\text { Bicarbonate } \\
\text { (mg/L as } \\
\left.\mathrm{HCO}_{3}\right)\end{array}$ & $\begin{array}{l}\text { Boron } \\
(\mu \mathrm{g} / \mathrm{L} \\
\text { as B) }\end{array}$ & $\begin{array}{c}\text { Bromide } \\
\text { (mg/L } \\
\text { as Br) }\end{array}$ & $\begin{array}{l}\text { Calcium } \\
\text { (mg/L as } \\
\text { Ca) }\end{array}$ & $\begin{array}{c}\text { Carbonate } \\
(\mathrm{mg} / \mathrm{L} \text { as } \\
\left.\mathrm{CO}_{3}\right)\end{array}$ & $\begin{array}{l}\text { Chloride } \\
\text { (mg/L as } \\
\text { Cl) }\end{array}$ \\
\hline 1 & 06-04-03 & 1300 & 203 & - & 248 & - & 0.3 & 82.1 & - & 274 \\
\hline 2 & 08-11-04 & 1100 & 175 & 2.7 & 213 & 199 & .37 & 94.7 & - & 284 \\
\hline 3 & $11-13-03$ & 1130 & 270 & .8 & 329 & 539 & .36 & 196 & - & 368 \\
\hline 4 & $05-12-03$ & 1300 & 71 & - & 77 & - & .06 & 21.7 & 5 & 43.2 \\
\hline 5 & $08-20-03$ & 1500 & 184 & .4 & 225 & 28 & .02 & 57 & - & 11.1 \\
\hline 6 & $07-27-04$ & 1045 & 140 & 3.6 & 171 & 26 & .07 & 32.8 & - & 44.9 \\
\hline 7 & 09-04-03 & 1100 & 159 & 2.6 & 194 & 30 & .09 & 45.7 & - & 69.5 \\
\hline 8 & $09-12-03$ & 1000 & 241 & 1.2 & 294 & 30 & .06 & 86.1 & - & 35.9 \\
\hline 9 & 09-16-03 & 1300 & 272 & .6 & 331 & 46 & .03 & 96.2 & - & 12.2 \\
\hline 10 & 09-08-04 & 1000 & 95 & 2.9 & 116 & 10 & .02 & 24.6 & - & 10.7 \\
\hline 11 & $09-12-03$ & 1100 & 118 & 5.1 & 143 & 21 & .02 & 21 & - & 6.84 \\
\hline 12 & 09-04-03 & 1430 & 157 & 1.2 & 191 & 13 & .02 & 44 & - & 12.8 \\
\hline 13 & 08-02-04 & 1315 & 142 & 3 & 173 & 75 & .13 & 75.5 & - & 112 \\
\hline 14 & $08-28-03$ & 1430 & 153 & .3 & 187 & 12 & e .02 & 60.5 & - & 7.09 \\
\hline 15 & $09-16-03$ & 1100 & 181 & .6 & 220 & 14 & .03 & 50.6 & - & 8.04 \\
\hline 16 & $07-20-04$ & 1200 & 168 & .3 & 205 & 16 & e .01 & 58.9 & - & 6.98 \\
\hline 17 & $07-29-04$ & 1300 & 274 & .8 & 334 & 84 & .13 & 115 & - & 70 \\
\hline 18 & $07-20-04$ & 0930 & 106 & 1.3 & 130 & 8.6 & $<.02$ & 28.1 & - & 5.64 \\
\hline 19 & $07-28-04$ & 1245 & 168 & .5 & 205 & 14 & .02 & 48.1 & - & 8.1 \\
\hline 20 & $08-12-04$ & 1300 & 280 & .9 & 342 & 71 & .06 & 70.1 & - & 23.2 \\
\hline 21 & $08-16-04$ & 1200 & 258 & 1.2 & 314 & 65 & .07 & 84.8 & - & 24.5 \\
\hline 22 & 08-11-04 & 1300 & 275 & 1.9 & 335 & 53 & .09 & 92.5 & - & 26.5 \\
\hline 23 & 07-29-04 & 1045 & 184 & .2 & 225 & 29 & .03 & 54.4 & - & 10.7 \\
\hline 24 & 07-30-04 & 1245 & 279 & .3 & 339 & 56 & .07 & 83.4 & - & 21.5 \\
\hline 25 & $07-21-04$ & 1400 & 179 & e. 1 & 219 & 28 & $<.02$ & 47.4 & - & 4.38 \\
\hline 26 & $07-21-04$ & 1330 & 265 & 2.8 & 324 & 39 & .23 & 93.5 & - & 20.7 \\
\hline 27 & $08-17-04$ & 1100 & 181 & 1.5 & 220 & 28 & .06 & 55 & - & 28.9 \\
\hline 28 & $04-22-04$ & 1500 & 109 & 2.8 & 133 & 22 & .02 & 23 & - & 19.9 \\
\hline 29 & 04-23-04 & 1200 & 235 & 1.8 & 287 & 58 & .06 & 79 & - & 26.2 \\
\hline 30 & 08-13-04 & 1200 & 244 & 2.2 & 297 & 70 & .06 & 79.8 & - & 19 \\
\hline 31 & 08-16-04 & 1000 & 180 & 1.2 & 219 & 51 & .04 & 59.8 & - & 16.6 \\
\hline 32 & 08-24-04 & 1100 & 202 & - & 246 & - & .03 & 74.9 & - & 12.8 \\
\hline 33 & 09-08-04 & 1400 & 229 & 1.9 & 280 & 56 & .05 & 63.4 & - & 11.5 \\
\hline 34 & 09-09-04 & 1200 & 225 & 1.3 & 274 & 56 & .07 & 65.1 & - & 11.3 \\
\hline 35 & $07-27-05$ & 1530 & - & - & - & - & - & - & - & - \\
\hline $36 \mathrm{a}$ & 08-06-05 & 1400 & - & - & - & - & - & - & - & - \\
\hline $36 \mathrm{~b}$ & 08-10-05 & 0700 & - & - & - & - & - & - & - & - \\
\hline $36 c$ & 08-11-05 & 0840 & - & - & - & - & - & - & - & - \\
\hline $36 \mathrm{~d}$ & 08-12-05 & 2130 & - & - & - & - & - & - & - & - \\
\hline $36 \mathrm{e}$ & 08-14-05 & 0215 & - & - & - & - & - & - & - & - \\
\hline
\end{tabular}


Table 20. Physical properties and concentration of dissolved ions in ground water, northern Utah Valley, Utah, 2003-05-Continued.

[Sample identifier: see figure 35 for the location of sites sampled as part of this study. A bbreviations: $\mathrm{mm} \mathrm{Hg}$, millimeters of mercury; ${ }^{\circ} \mathrm{C}$, degrees Celsius; $\mu \mathrm{S} /$ $\mathrm{cm}$, microsiemens per centimeter at 25 degrees Celsius; mg/L, milligrams per liter; $\mu \mathrm{g} / \mathrm{L}$, micrograms per liter; —, not analyzed; <, less than; e, estimated]

\begin{tabular}{|c|c|c|c|c|c|c|c|c|c|c|}
\hline $\begin{array}{l}\text { Sample } \\
\text { identifier }\end{array}$ & $\begin{array}{c}\text { Sample } \\
\text { date }\end{array}$ & $\begin{array}{c}\text { Sample } \\
\text { time }\end{array}$ & $\begin{array}{l}\text { Fluoride } \\
\text { (mg/L as F) }\end{array}$ & $\begin{array}{c}\text { Iron } \\
(\mu \mathrm{g} / \mathrm{L} \text { as Fe) }\end{array}$ & $\begin{array}{l}\text { Magnesium } \\
\text { (mg/L as } \mathrm{Mg})\end{array}$ & $\begin{array}{l}\text { Manganese } \\
\text { ( } \mu \mathrm{g} / \mathrm{L} \text { as } \mathrm{Mn})\end{array}$ & $\begin{array}{l}\text { Potassium } \\
\text { (mg/L as K) }\end{array}$ & $\begin{array}{c}\text { Silica } \\
\text { (mg/L as } \\
\mathrm{SiO}_{2} \text { ) }\end{array}$ & $\begin{array}{c}\text { Sodium } \\
\text { (mg/L as } \\
\mathrm{Na} \text { ) }\end{array}$ & $\begin{array}{c}\text { Solids, } \\
\text { residue on } \\
\text { evaporation } \\
\text { at } 180^{\circ} \mathrm{C} \\
(\mathrm{mg} / \mathrm{L})\end{array}$ \\
\hline 1 & $06-04-03$ & 1300 & 2.3 & 11 & 39.4 & 0.6 & 9.61 & 16.1 & 189 & 1,030 \\
\hline 2 & 08-11-04 & 1100 & 1.1 & 8 & 43.1 & 1 & 6.06 & 26.4 & 106 & 783 \\
\hline 3 & $11-13-03$ & 1130 & 1.8 & 596 & 51.5 & 282 & 24.9 & 29.4 & 235 & 1,590 \\
\hline 4 & $05-12-03$ & 1300 & .37 & 47 & 11.1 & 64 & 4.23 & .6 & 11.6 & 144 \\
\hline 5 & $08-20-03$ & 1500 & .2 & $<8$ & 20.7 & e .3 & 1.75 & 12.9 & 8.34 & 276 \\
\hline 6 & $07-27-04$ & 1045 & .2 & 10 & 19.4 & 1.2 & 2.12 & 28.2 & 25.5 & 244 \\
\hline 7 & 09-04-03 & 1100 & .3 & $<8$ & 21.3 & e .3 & 2.58 & 28.1 & 22.9 & 303 \\
\hline 8 & $09-12-03$ & 1000 & $<.2$ & e 6 & 24 & e .4 & 2.58 & 17.1 & 30.4 & 440 \\
\hline 9 & $09-16-03$ & 1300 & .3 & $<8$ & 24.8 & $<.4$ & 3.86 & 19.2 & 11.3 & 414 \\
\hline 10 & 09-08-04 & 1000 & .3 & $<6$ & 10.9 & $<.8$ & 1.37 & 14.6 & 8.35 & 144 \\
\hline 11 & $09-12-03$ & 1100 & .4 & 12 & 10.1 & 1.8 & 3.7 & 17.6 & 13.7 & 148 \\
\hline 12 & 09-04-03 & 1430 & .2 & e 5 & 18.2 & .4 & 1.25 & 13.9 & 11.4 & 241 \\
\hline 13 & $08-02-04$ & 1315 & .3 & $<6$ & 30.7 & 4.6 & 2.91 & 19.7 & 39.7 & 473 \\
\hline 14 & $08-28-03$ & 1430 & .4 & e 7 & 22.1 & e .3 & .68 & 8.09 & 4.85 & 316 \\
\hline 15 & $09-16-03$ & 1100 & .2 & e 4 & 22.9 & e. 3 & 1.33 & 13.1 & 8.64 & 256 \\
\hline 16 & $07-20-04$ & 1200 & .2 & $<6$ & 23.2 & $<4.8$ & .9 & 9.34 & 6.95 & 259 \\
\hline 17 & 07-29-04 & 1300 & 1.2 & e 3 & 64.2 & e .6 & 1.52 & 13.6 & 48 & 778 \\
\hline 18 & 07-20-04 & 0930 & .2 & $<6$ & 12.6 & $<.8$ & 1.39 & 10.9 & 8.38 & 151 \\
\hline 19 & $07-28-04$ & 1245 & .2 & $<6$ & 20.6 & $<.8$ & 1.19 & 10.5 & 13.2 & 256 \\
\hline 20 & $08-12-04$ & 1300 & .4 & $<6$ & 40.5 & e .6 & 4.05 & 17 & 23.8 & 409 \\
\hline 21 & 08-16-04 & 1200 & .3 & 109 & 35.7 & 125 & 1.89 & 14.3 & 34.7 & 457 \\
\hline 22 & $08-11-04$ & 1300 & .3 & 1,690 & 36.6 & 233 & 1.93 & 12.9 & 35.2 & 491 \\
\hline 23 & 07-29-04 & 1045 & .4 & $<6$ & 23.3 & $<.8$ & 1 & 11 & 13.7 & 268 \\
\hline 24 & $07-30-04$ & 1245 & .2 & e 4 & 35.4 & $<.8$ & 2.3 & 10.9 & 19.9 & 393 \\
\hline 25 & $07-21-04$ & 1400 & .4 & 340 & 18.9 & 30 & 2.17 & 13.1 & 10.4 & 228 \\
\hline 26 & $07-21-04$ & 1330 & .2 & 2,400 & 34.2 & 317 & 1.06 & 12.5 & 21.5 & 439 \\
\hline 27 & 08-17-04 & 1100 & .2 & e 6 & 25 & $<.8$ & 1.73 & 17.7 & 16.6 & 319 \\
\hline 28 & $04-22-04$ & 1500 & .3 & $<6$ & 8.69 & 9.5 & 1.45 & 14.7 & 23.9 & 167 \\
\hline 29 & 04-23-04 & 1200 & .2 & 24 & 27.6 & 5.9 & 5.87 & 20.4 & 18 & 314 \\
\hline 30 & 08-13-04 & 1200 & .2 & $<6$ & 23.9 & $<.8$ & 4.53 & 20.7 & 18.2 & 332 \\
\hline 31 & 08-16-04 & 1000 & .2 & e 4 & 16.8 & $<.8$ & 1.83 & 10.9 & 12.6 & 249 \\
\hline 32 & 08-24-04 & 1100 & .2 & e 3 & 18.9 & $<.8$ & 2.49 & 14.2 & 10.9 & 309 \\
\hline 33 & 09-08-04 & 1400 & .3 & 684 & 23.8 & 72 & 2.92 & 20.5 & 15.9 & 312 \\
\hline 34 & 09-09-04 & 1200 & .3 & 649 & 23.6 & 81 & 2.86 & 20.4 & 17.1 & 304 \\
\hline 35 & $07-27-05$ & 1530 & - & - & - & - & - & - & - & - \\
\hline $36 a$ & 08-06-05 & 1400 & - & - & - & - & - & - & - & - \\
\hline $36 b$ & 08-10-05 & 0700 & - & - & - & - & - & - & - & - \\
\hline $36 c$ & 08-11-05 & 0840 & - & - & - & - & - & - & - & - \\
\hline $36 \mathrm{~d}$ & $08-12-05$ & 2130 & - & - & - & - & - & - & - & - \\
\hline $36 \mathrm{e}$ & 08-14-05 & 0215 & - & - & - & - & - & - & - & - \\
\hline
\end{tabular}


Table 20. Physical properties and concentration of dissolved ions in ground water, northern Utah Valley, Utah, 2003-05-Continued.

[Sample identifier: see figure 35 for the location of sites sampled as part of this study. Abbreviations: mm Hg, millimeters of mercury; ${ }^{\circ} \mathrm{C}$, degrees Celsius; $\mu \mathrm{S} /$ $\mathrm{cm}$, microsiemens per centimeter at 25 degrees Celsius; mg/L, milligrams per liter; $\mu \mathrm{g} / \mathrm{L}$, micrograms per liter; —, not analyzed; <, less than; e, estimated]

\begin{tabular}{|c|c|c|c|c|c|c|c|c|c|c|}
\hline $\begin{array}{c}\text { Sample } \\
\text { identifier }\end{array}$ & $\begin{array}{l}\text { Sample } \\
\text { date }\end{array}$ & $\begin{array}{c}\text { Sample } \\
\text { time }\end{array}$ & $\begin{array}{c}\text { Sulfate } \\
\left(\mathrm{mg} / \mathrm{L} \text { as } \mathrm{SO}_{4}\right)\end{array}$ & $\begin{array}{l}\text { Ammonia } \\
\text { (mg/L as N) }\end{array}$ & $\begin{array}{c}\text { Nitrate + } \\
\text { nitrite } \\
\text { (mg/L as N) }\end{array}$ & $\begin{array}{c}\text { Nitrite } \\
\text { (mg/L as N) }\end{array}$ & $\begin{array}{c}\text { Ortho- } \\
\text { phosphate } \\
\text { (mg/L as } P \text { ) }\end{array}$ & $\begin{array}{c}\text { Phos- } \\
\text { phorus } \\
\text { (mg/L as } P)\end{array}$ & $\begin{array}{c}\text { Ammonia } \\
+ \text { organic } \\
\text { nitrogen } \\
\text { (mg/L as N) }\end{array}$ & $\begin{array}{l}\text { Total nitro- } \\
\text { gen } \\
\text { (mg/L as } \mathrm{N})\end{array}$ \\
\hline 1 & 06-04-03 & 1300 & 228 & $<0.04$ & 0.09 & $<0.008$ & $<0.02$ & - & $<0.1$ & - \\
\hline 2 & 08-11-04 & 1100 & 77.9 & $<.04$ & 2.02 & $<.008$ & e .005 & 0.005 & - & 2.05 \\
\hline 3 & $11-13-03$ & 1130 & 438 & .1 & $<.06$ & $<.008$ & $<.006$ & - & - & .11 \\
\hline 4 & $05-12-03$ & 1300 & .3 & .22 & $<.06$ & $<.008$ & .03 & - & .24 & - \\
\hline 5 & $08-20-03$ & 1500 & 26.2 & $<.04$ & 2.45 & $<.008$ & e. 01 & - & e .05 & - \\
\hline 6 & $07-27-04$ & 1045 & 10.5 & $<.04$ & .44 & $<.008$ & .006 & - & - & .49 \\
\hline 7 & 09-04-03 & 1100 & 11.4 & $<.04$ & .73 & $<.008$ & e .01 & - & $<.1$ & - \\
\hline 8 & $09-12-03$ & 1000 & 77.9 & $<.04$ & .99 & $<.008$ & $<.18$ & - & e. 05 & - \\
\hline 9 & $09-16-03$ & 1300 & 49.8 & $<.04$ & 4.14 & $<.008$ & $<.18$ & - & .12 & - \\
\hline 10 & 09-08-04 & 1000 & 7 & $<.04$ & .72 & $<.008$ & .009 & .01 & - & .71 \\
\hline 11 & $09-12-03$ & 1100 & 5.3 & $<.04$ & .13 & $<.008$ & e .01 & - & $<.1$ & - \\
\hline 12 & 09-04-03 & 1430 & 36.4 & $<.04$ & 1.22 & $<.008$ & $<.02$ & - & $<.1$ & - \\
\hline 13 & $08-02-04$ & 1315 & 102 & e .03 & .07 & $<.008$ & .009 & - & - & .1 \\
\hline 14 & $08-28-03$ & 1430 & 92.8 & $<.04$ & .15 & $<.008$ & $<.02$ & - & $<.1$ & - \\
\hline 15 & $09-16-03$ & 1100 & 32.4 & $<.04$ & .53 & $<.008$ & $<.18$ & - & $<.1$ & - \\
\hline 16 & $07-20-04$ & 1200 & 60.2 & $<.04$ & .56 & $<.008$ & $<.006$ & - & - & .56 \\
\hline 17 & 07-29-04 & 1300 & 251 & $<.04$ & 4.36 & $<.008$ & $<.006$ & - & - & 4.29 \\
\hline 18 & $07-20-04$ & 0930 & 12.7 & $<.04$ & 1.65 & $<.008$ & e. .005 & - & - & 1.75 \\
\hline 19 & $07-28-04$ & 1245 & 48 & $<.04$ & 1.56 & $<.008$ & $<.006$ & - & - & 1.66 \\
\hline 20 & $08-12-04$ & 1300 & 72.6 & $<.04$ & 1.6 & $<.008$ & $<.006$ & e. .003 & - & 1.62 \\
\hline 21 & $08-16-04$ & 1200 & 133 & $<.04$ & 1.48 & $<.008$ & e .003 & $<.004$ & - & 1.42 \\
\hline 22 & 08-11-04 & 1300 & 135 & e. 04 & $<.06$ & $<.008$ & .007 & .01 & - & .06 \\
\hline 23 & 07-29-04 & 1045 & 52.7 & $<.04$ & .76 & $<.008$ & e .004 & - & - & .78 \\
\hline 24 & 07-30-04 & 1245 & 74.5 & $<.04$ & 2.7 & $<.008$ & e .003 & - & - & 2.66 \\
\hline 25 & $07-21-04$ & 1400 & 28.4 & 1.08 & $<.06$ & $<.008$ & .053 & - & - & 1.14 \\
\hline 26 & $07-21-04$ & 1330 & 108 & .09 & $<.06$ & e .004 & .006 & - & - & .08 \\
\hline 27 & 08-17-04 & 1100 & 53.3 & $<.04$ & 1.21 & $<.008$ & .011 & .013 & - & 1.18 \\
\hline 28 & 04-22-04 & 1500 & 6.6 & $<.04$ & .16 & $<.008$ & .013 & .014 & - & .17 \\
\hline 29 & 04-23-04 & 1200 & 57.2 & $<.04$ & 1.77 & $<.008$ & .023 & .027 & - & 1.81 \\
\hline 30 & 08-13-04 & 1200 & 62.4 & $<.04$ & .56 & $<.008$ & .031 & .036 & - & .56 \\
\hline 31 & 08-16-04 & 1000 & 38.9 & $<.04$ & .53 & $<.008$ & .006 & .009 & - & .52 \\
\hline 32 & $08-24-04$ & 1100 & 66.7 & $<.04$ & .44 & $<.008$ & .008 & - & - & .44 \\
\hline 33 & 09-08-04 & 1400 & 43.9 & .26 & $<.06$ & $<.008$ & .023 & .013 & - & .28 \\
\hline 34 & 09-09-04 & 1200 & 38.4 & .32 & $<.06$ & $<.008$ & .031 & .041 & - & .33 \\
\hline 35 & $07-27-05$ & 1530 & - & - & - & - & - & - & - & - \\
\hline $36 a$ & $08-06-05$ & 1400 & - & - & - & - & - & - & - & - \\
\hline $36 \mathrm{~b}$ & $08-10-05$ & 0700 & - & - & - & - & - & - & - & - \\
\hline $36 c$ & $08-11-05$ & 0840 & - & - & - & - & - & - & - & - \\
\hline $36 \mathrm{~d}$ & 08-12-05 & 2130 & - & - & - & - & - & - & - & - \\
\hline $36 \mathrm{e}$ & 08-14-05 & 0215 & - & - & - & - & - & - & - & - \\
\hline
\end{tabular}




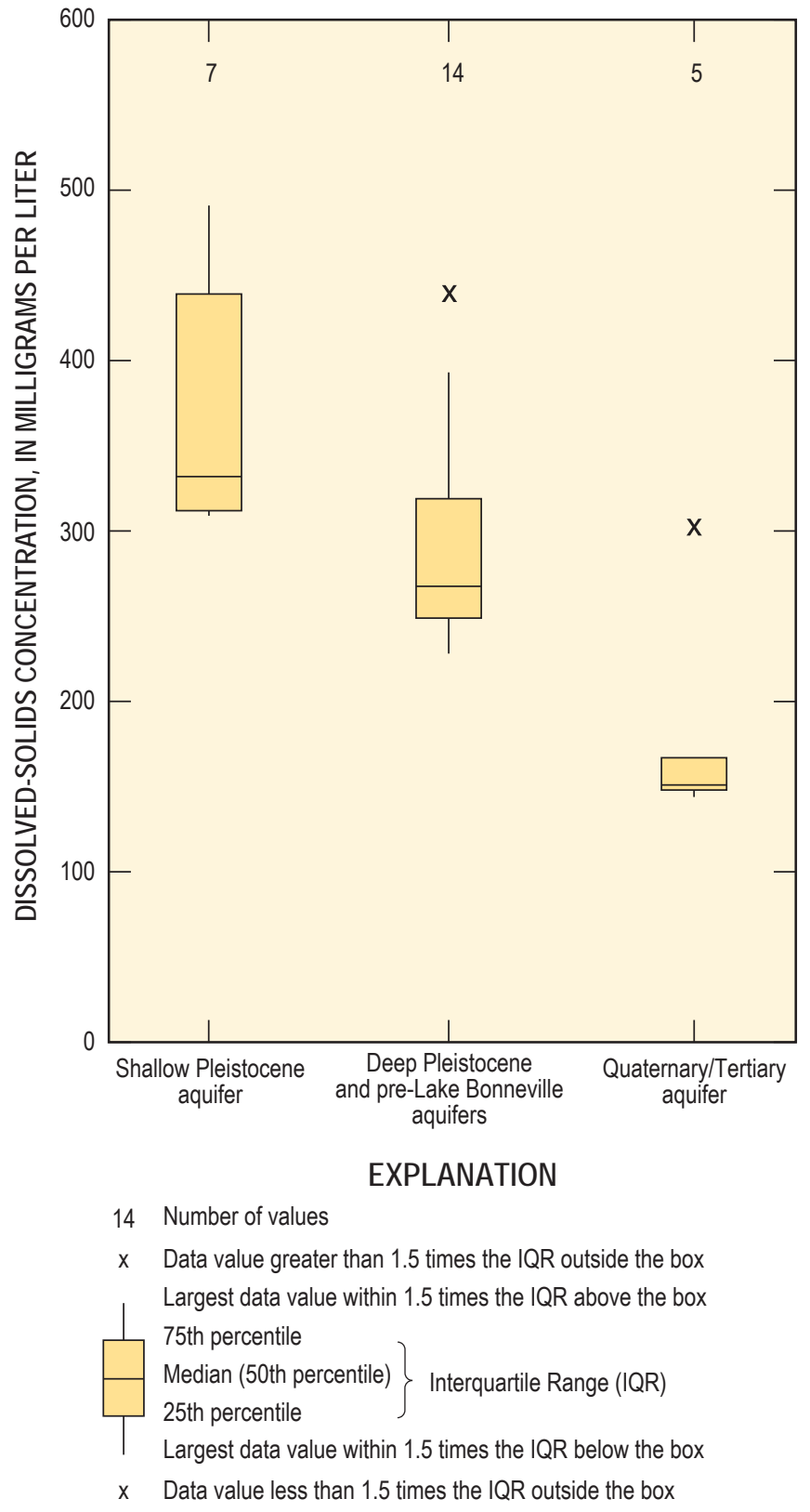

Figure 37. Dissolved-solids concentration in water samples collected from the shallow Pleistocene, combined deep Pleistocene and pre-Lake Bonneville, and Quaternary/Tertiary aquifers in northern Utah Valley, Utah, 2003-05.

solids concentration in water from wells completed in the PLB and DP aquifers combined ranged from 228 to $440 \mathrm{mg} / \mathrm{L}$ with a median value of $259 \mathrm{mg} / \mathrm{L}$. Samples collected from wells in the deep QT aquifer had the lowest median dissolved-solids concentration of $151 \mathrm{mg} / \mathrm{L}$ and ranged from 144 to $303 \mathrm{mg} / \mathrm{L}$. Generally, samples from the QT aquifer also exhibit a slightly different water type than samples collected from the SP, DP, and PLB aquifers, where the percentage of sulfate is generally less than 10 percent of the anion composition (fig. 36).
Nitrate in ground water can be an indicator of human activities including but not limited to agriculture, stock yards, and urbanization. Natural background levels of nitrate in ground water are generally considered to be at or less than about $3 \mathrm{mg} / \mathrm{L}$ (Hem, 1992). Values above the background level may indicate that a local recharge source affected by human activities is contributing to sampled water. Nitrate is reported as dissolved nitrate plus nitrite in this report, but because nitrite was detected in only one sample and at an order of magnitude less than the laboratory reporting limit for nitrate, the measured nitrate plus nitrite concentrations will be referred to as nitrate in this report.

The median value for nitrate concentrations was 0.56 $\mathrm{mg} / \mathrm{L}$ for ground water sampled in northern Utah Valley (fig. 38) indicating that most of the samples were not influenced by recent human activities at the land surface. Only two samples, sample 9 and sample 17, had detections near or above the natural background level, 4.14 and $4.36 \mathrm{mg} / \mathrm{L}$, respectively (table 20). Sample 9 was collected from a shallow spring system on the Highland Bench supplied by a perched zone above the SP aquifer. The spring system is located near Dry Creek and in an area typically used for agriculture and grazing. Sample 8 was collected from a well finished in the DP aquifer at a depth of $214 \mathrm{ft}$ that underlies the perched zone contributing water to the spring that sample 9 was collected from. Sample 8 had a nitrate concentration of $0.99 \mathrm{mg} / \mathrm{L}$. The low concentration compared to the spring indicates that the perched water is not contributing to the underlying DP aquifer in this area. Because of the higher nitrate concentration, at least a portion of the recharge water to the spring is likely a mixture of seepage from Dry Creek to the perched basin-fill aquifer and seepage from irrigation return flows within the agricultural and grazed lands adjacent to and upgradient of the well. Sample 17, as discussed previously, is likely affected by surficial activities and not representative of regional characteristics, but the higher nitrate values may indicate that localized recharge to the basin-fill aquifers is occurring.

\section{Historical Data}

Specific-conductance and dissolved-solids data for ground water sampled in northern Utah Valley were pulled from the USGS National Water Information System (NWIS) database (U.S. Geological Survey, 2006) and from the Utah Division of Drinking Water database (Utah Division of Drinking Water, written commun., 2005). Values for samples collected during 1980-82 and 2004-05 were compared to evaluate the effects of changing land use and increased pumping on changes in water chemistry between the two study periods (table 21). Samples from each database generally included values for both specific conductance and dissolved-solids concentration, but some samples only had measured values for one property or the other. In order to increase the number of samples for analysis for either property, regression analysis was done on all of the samples, regardless of sample date, with 


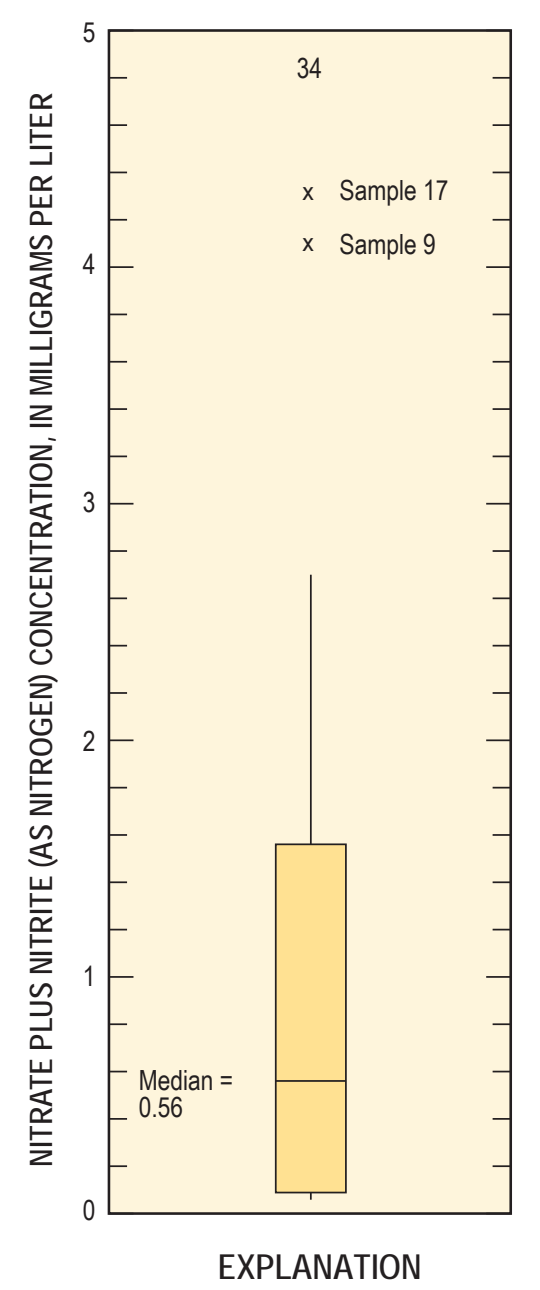

34 Number of values

$x$ Data value greater than 1.5 times the IQR outside the box Largest data value within 1.5 times the IQR above the box 75th percentile Median (50th percentile) $\quad$ Interquartile Range (IQR) 25th percentile

Largest data value within 1.5 times the IQR below the box

$x$ Data value less than 1.5 times the IQR outside the box

Figure 38. Dissolved nitrate plus nitrite concentration in ground water sampled in northern Utah Valley, Utah, 2003-04.

measured values of both specific conductance and dissolved solids to develop the linear equation 4 (fig. 39):

$$
\mathrm{SC}=1.5938 \times \mathrm{DS}+21.841
$$

where

$$
\mathrm{SC} \quad \text { is specific conductance }(\mu \mathrm{S} / \mathrm{cm}) \text {, }
$$

and

DS is dissolved-solids concentration (mg/L).
Ground-water quality in the principal basin-fill aquifer, as determined from specific-conductance values and dissolvedsolids concentrations, has remained fairly consistent in northern Utah Valley since the Clark and Appel study (1985) for 1980-82, with no significant increase or decrease in specificconductance or dissolved-solids concentration detected from the samples analyzed (fig. 40). Of 22 wells sampled for specific conductance or dissolved solids during 1980-82 and 2004-05, four water samples had an increase of more than 12.5 percent (one standard deviation) in specific-conductance value and three water samples had an increase in dissolvedsolids concentration of more than 15 percent (one standard deviation) from the previous study (table 21). The increase in a few wells indicates that varying aquifer conditions may occur on a local scale. The detected increases still remain well below established drinking-water standards.

\section{Stable Isotopes}

The stable isotopes of water, including deuterium $\left({ }^{2} \mathrm{H}\right.$ or D) and oxygen-18 $\left({ }^{18} \mathrm{O}\right)$, can be used as indicators of recharge sources to an aquifer. Isotope compositions in water vapor, rain, and snow vary with altitude. The heavier isotopes $\mathrm{D}$ and ${ }^{18} \mathrm{O}$ are less abundant than the lighter isotopes hydrogen $(\mathrm{H})$ and oxygen- $16\left({ }^{16} \mathrm{O}\right)$ at higher altitudes. As altitude decreases, the relative abundance of the heavier isotopes increases.

Evaporation of surface water that may become recharge often occurs at lower altitudes and may alter the isotope ratio by depleting water of the lighter isotope. The resulting recharge water has a heavier isotopic signature that can be an indication of the recharge source by correlating the isotopic ratios with altitude or known surface-water compositions. Stable-isotope ratios are reported as delta $(\delta)$ values expressed as parts per thousand or permil (\%o). The $\delta$ value is determined by:

$$
\delta=\left(R_{\text {sample }} / R_{\text {standard }}-1\right) \times 1000 \% \text { o }
$$

where

$$
R_{\text {sample }} \quad \text { represents the isotopic ratio (either }{ }^{2} \mathrm{H} /{ }^{1} \mathrm{H} \text { or }
$$$$
\left.{ }^{18} \mathrm{O} /{ }^{16} \mathrm{O}\right) \text { of the sample, }
$$

and

$$
\begin{gathered}
R_{\text {standard }} \quad \text { is the isotope ratio of VSMOW (Vienna } \\
\text { Standard Mean Ocean Water). }
\end{gathered}
$$

The isotope signature is conservative once the recharge water reaches the water table. The correlation of $\delta \mathrm{D}$ and $\delta^{18} \mathrm{O}$ in water is often defined by the global meteoric water line with the equation $\delta \mathrm{D}=8 \times \delta^{18} \mathrm{O}+10$ (Craig, 1961). Local variations to this line occur in response to physical location, topography, and evaporation.

$\delta \mathrm{D}$ and $\delta^{18} \mathrm{O}$ isotope values for water samples collected from wells and springs in northern Utah Valley ranged from -118 to -127 permil and from -15.86 to -17.00 permil, respectively (table 22). Values generally trend with the global meteoric water line (fig. 41) and cluster together in a fairly narrow band along the line, indicating that the recharge source 
Table 21. Specific conductance and dissolved-solids concentration of water from wells sampled in northern Utah Valley, Utah, 1980-82 and 2004-05.

[Well identifier: see front of report for an explanation of the well-numbering system used in Utah. Notes: S, State of Utah database; 1, specific conductance calculated from dissolved-solids concentration; 2, dissolved-solids concentration calculated from specific conductance; U, U.S. Geological Survey database. Abbreviations: $\mu \mathrm{S} / \mathrm{cm}$, microsiemens per centimeter; $\mathrm{mg} / \mathrm{L}$, milligrams per liter]

\begin{tabular}{|c|c|c|c|c|c|c|c|c|}
\hline \multirow[b]{2}{*}{ Well identifier } & \multicolumn{3}{|c|}{1980 to 1982} & \multicolumn{3}{|c|}{2004 to 2005} & \multirow{2}{*}{$\begin{array}{c}\text { Specific } \\
\text { conductance } \\
\text { (percent } \\
\text { difference) }\end{array}$} & \multirow{2}{*}{$\begin{array}{c}\text { Dissolved-solids } \\
\text { concentration } \\
\text { (percent differ- } \\
\text { ence) }\end{array}$} \\
\hline & $\begin{array}{c}\text { Specific } \\
\text { conductance } \\
(\mu \mathrm{S} / \mathrm{cm})\end{array}$ & $\begin{array}{c}\text { Dissolved-solids } \\
\text { concentration } \\
\text { (mg/L) }\end{array}$ & Notes & $\begin{array}{c}\text { Specific } \\
\text { conductance } \\
(\mu \mathrm{S} / \mathrm{cm})\end{array}$ & $\begin{array}{l}\text { Dissolved-solids } \\
\text { concentration } \\
(\mathrm{mg} / \mathrm{L})\end{array}$ & Notes & & \\
\hline$(\mathrm{C}-5-1) 12 \mathrm{dcc}-1$ & 840 & 501 & $\mathrm{~S}$ & 750 & 446 & $\mathrm{U}$ & -10.7 & -11.0 \\
\hline (D-4-1)36ddd-1 & 490 & 269 & $\mathrm{U}$ & 477 & 296 & $\mathrm{U}, 1$ & -2.7 & 10.0 \\
\hline (D-4-2)31bda-1 & 365 & 194 & $\mathrm{U}$ & 495 & 308 & $\mathrm{~S}, 1$ & 35.5 & 58.8 \\
\hline (D-5-1)1cdc-1 & 490 & 282 & $\mathrm{~S}$ & 443 & 270 & $\mathrm{U}$ & -9.6 & -4.3 \\
\hline (D-5-1)14bdc-1 & 260 & 139 & $\mathrm{U}$ & 248 & 151 & $\mathrm{U}$ & -4.6 & 8.6 \\
\hline (D-5-1) 17 adc-12 & 245 & 137 & $\mathrm{~S}, 2$ & 248 & 139 & $\mathrm{U}, 2$ & 1.2 & 1.4 \\
\hline (D-5-1)19bcb-2 & 240 & 134 & $\mathrm{U}, 2$ & 250 & 140 & $\mathrm{U}, 2$ & 4.2 & 4.5 \\
\hline (D-5-1)20aba-1 & 260 & 148 & $\mathrm{U}$ & 293 & 167 & $\mathrm{U}, 2$ & 12.7 & 12.6 \\
\hline (D-5-1)21dda-2 & 400 & 222 & $\mathrm{U}$ & 405 & 235 & $\mathrm{U}, 2$ & 1.3 & 5.9 \\
\hline (D-5-1)27daa-1 & 620 & 484 & $\mathrm{U}$ & 750 & 446 & $\mathrm{U}$ & 21.0 & -7.9 \\
\hline (D-5-2)27baa-1 & 560 & 309 & $\mathrm{U}$ & 484 & 281 & $\mathrm{U}$ & -13.6 & -9.1 \\
\hline (D-5-2)30ccb-2 & 800 & 477 & $\mathrm{~S}, 2$ & 820 & 489 & $\mathrm{U}, 2$ & 2.5 & 2.6 \\
\hline (D-5-2)32bdb-2 & 630 & 373 & $\mathrm{U}, 2$ & 630 & 373 & $\mathrm{U}, 2$ & 0 & 0 \\
\hline (D-5-2)32bdb-3 & 390 & 226 & $\mathrm{U}, 2$ & 432 & 252 & $\mathrm{U}, 2$ & 10.8 & 11.4 \\
\hline (D-6-2)6acc-1 & 780 & 439 & $\mathrm{U}$ & 730 & 434 & $\mathrm{U}, 2$ & -6.4 & -1.2 \\
\hline (D-6-2)9dab-1 & 450 & 284 & $\mathrm{U}$ & 477 & 296 & $\mathrm{~S}, 1$ & 6.0 & 4.2 \\
\hline (D-6-2)13cab-1 & 385 & 238 & $\mathrm{U}$ & 492 & 306 & $\mathrm{~S}, 1$ & 27.7 & 28.6 \\
\hline (D-6-2)14bcd-1 & 460 & 263 & $\mathrm{U}$ & 525 & 312 & U & 14.1 & 18.6 \\
\hline (D-6-2)24caa-1 & 500 & 287 & $\mathrm{~S}$ & 480 & 294 & $\mathrm{U}$ & -4.0 & 2.4 \\
\hline (D-6-2)25bcb-1 & 390 & 243 & $\mathrm{U}$ & 400 & 244 & $\mathrm{~S}, 1$ & 2.5 & .4 \\
\hline (D-6-2) $25 \mathrm{dca}-1$ & 515 & 320 & $\mathrm{~S}$ & 516 & 322 & $\mathrm{~S}, 1$ & .1 & 6 \\
\hline (D-7-2)4cbb-2 & 580 & 324 & $\mathrm{U}$ & 530 & 321 & $\mathrm{U}$ & -8.6 & -.9 \\
\hline
\end{tabular}

is isotopically similar for most of the sampled wells. Historical samples of snow collected in the Wasatch Mountains have ratios slightly more depleted in the heavy isotope (lighter) than ground-water samples collected for this study. Samples from irrigation canals in Salt Lake Valley, supplied with evaporated water from Utah Lake, are heavier (less negative) (fig. 41) than ground water sampled from northern Utah Valley, where the majority of sources to ground water are either MBI (mountain block subsurface inflow) or seepage from streams and irrigation canals near the mountain front. Stable-isotope ratios indicate that for ground water sampled on the eastern side of the valley, nearly all of the recharge is derived from mountain precipitation that has not been exposed to prolonged periods of evaporation. However, a limitation of the stable-isotope tracers is that they are incapable of distinguishing between (1) mountain precipitation that recharged the valley aquifers as MBI and (2) seepage of water from streams and canals that also originated as mountain precipitation.

Most of the lightest isotopic ratios (fig. 41) were for ground water sampled from relatively deep wells completed in bedrock (samples 1 and 4), the QT aquifer (samples 7 and 28), or the PLB aquifer (sample 6). Light isotopic ratios representative of high-altitude mountain precipitation also were present in water sampled from shallower wells east of Utah Lake completed in the DP aquifer (samples 25 and 34) and the SP aquifer (sample 33). Water from all of the wells located near the front of the Wasatch Mountains (samples 14, 15, 17, 23, and 31) had $\delta^{18} \mathrm{O}$ and $\delta \mathrm{D}$ values that plotted higher (less negative) on the meteoric water line. This is indicative of lower altitude MBI or mountain-front recharge to these wells.

Sample 3, collected from a 110-ft deep well completed in basin-fill deposits west of Utah Lake, also had a relatively light isotopic ratio. Although the $\delta \mathrm{D}$ value for water from this well was similar to that of sample 1 collected from a well completed in limestone in the Cedar Pass area, the $\delta^{18} \mathrm{O}$ value was slightly more enriched, similar to samples collected from thermal springs in and around Utah Lake to the south (Baskin and others, 1994). The source of ground water from this well is not known.

Sample 2 plots relatively far off of the global meteoric line and is more enriched in $\delta^{18} \mathrm{O}$ relative to $\delta \mathrm{D}$ than other samples (fig. 41 inset), indicating an evaporated source of recharge water. Sample 2 was collected from a 253-ft deep well on the west side of the Jordan River that is completed in the WU aquifer. To the west of the well, upgradient hydraulically, are the unlined Jacob and Utah Lake Distribution Canals, which branch from the Provo Reservoir Canal in northern Utah Valley. The irrigation canals also convey water 


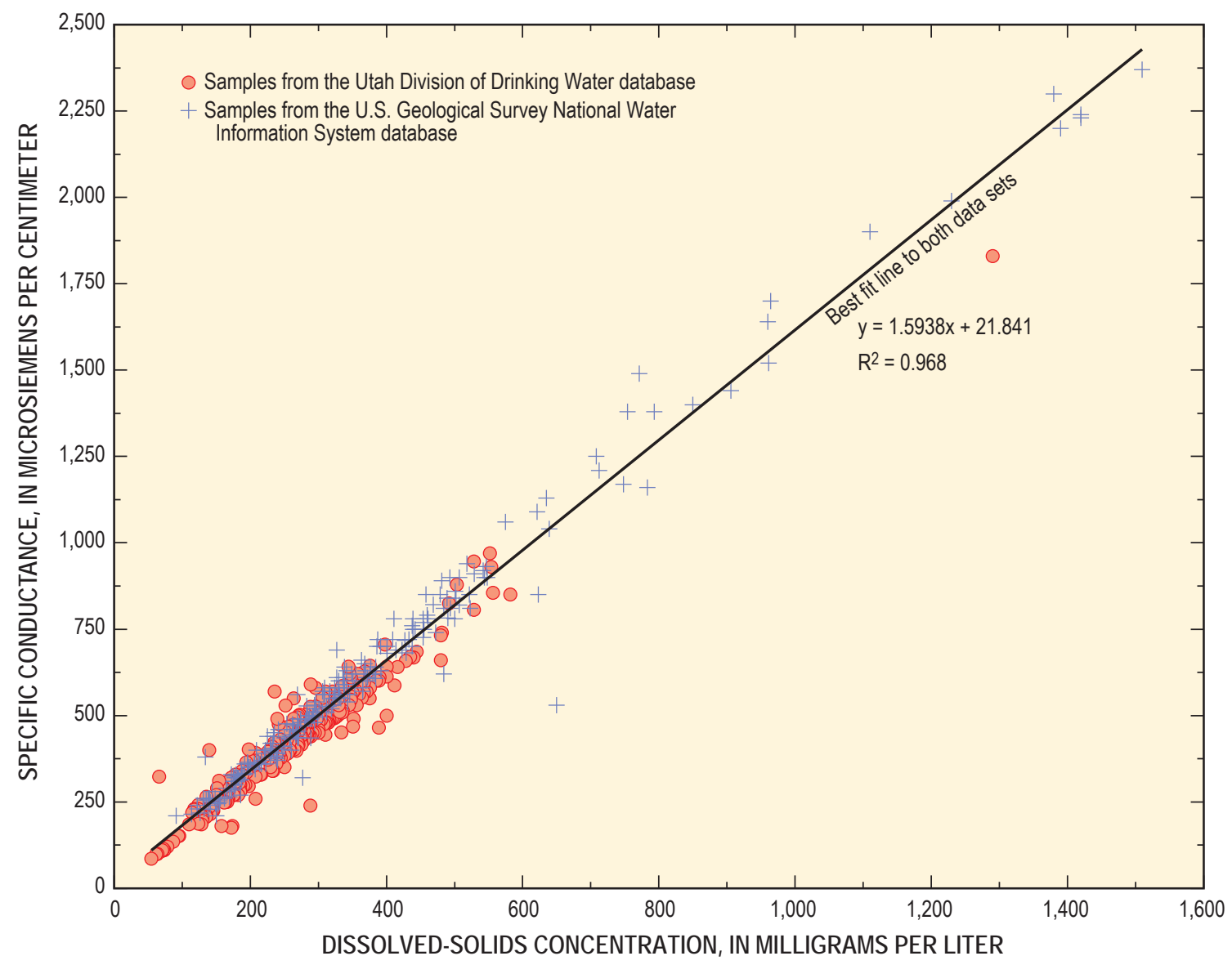

Figure 39. Correlation of specific conductance and dissolved-solids concentration in ground-water samples collected in northern Utah Valley, Utah, 1948-2005.

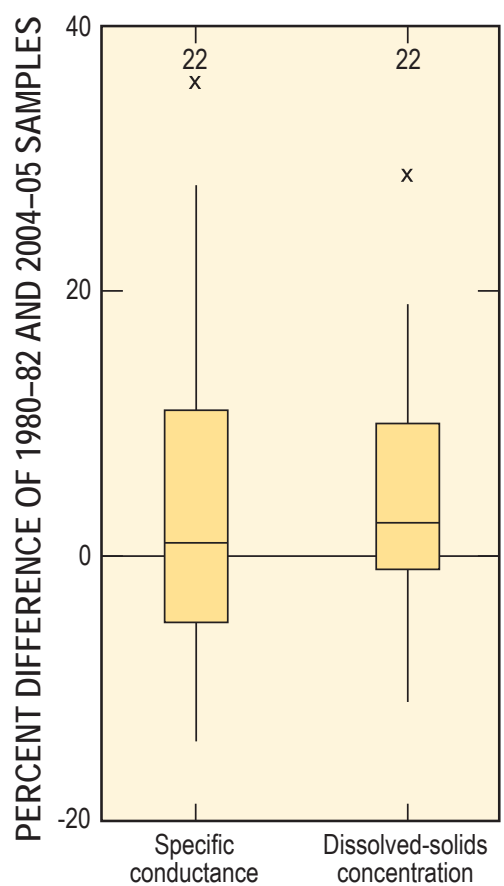

\section{EXPLANATION}

34 Number of values

$x$ Data value greater than 1.5 times the IQR outside the box

Largest data value within 1.5 times the IQR above the box

75th percentile

Median (50th percentile) $\}$ Interquartile Range (IQR)

25th percentile

Largest data value within 1.5 times the IQR below the box

$x$ Data value less than 1.5 times the IQR outside the box

Figure 40. Percent difference in specific conductance and dissolved-solids concentration for water samples collected from 22 wells in northern Utah Valley, Utah, during 1980-82 and 2004-05. 
Table 22. Stable-isotope, dissolved-gas, and recharge-temperature data for ground water sampled in northern Utah Valley, Utah, 2003-05.

[Sample identifier: see figure 35 for the location of sites sampled as part of this study. Contributing aquifer: B, bedrock; LB, Lake Bonneville; PLB, pre-Lake Bonneville; SP, shallow Pleistocene; DP, deep Pleistocene; QT, Quaternary/Tertiary; WU, Western unconsolidated. Dissolved-gas sample method: CT, copper tube; DS, diffusion sampler. A bbreviations: ccSTP/g, cubic centimeters at standard temperature and pressure per gram of water; ${ }^{\circ} \mathrm{C}$, degrees Celsius; $\mathrm{NC}$, not calculated; - , not analyzed]

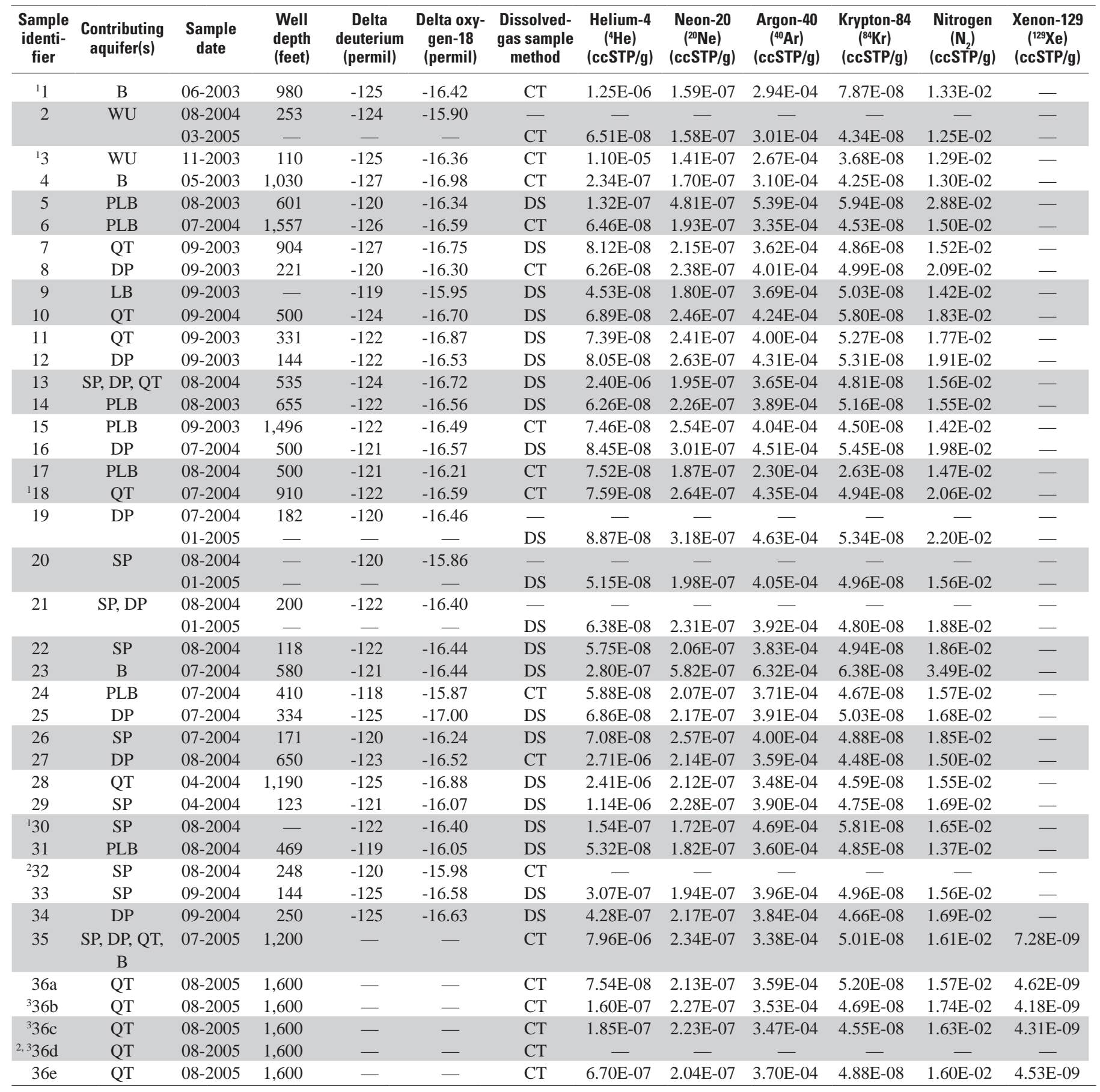


Table 22. Stable-isotope, dissolved-gas, and recharge-temperature data for ground water sampled in northern Utah Valley, Utah, 2003-05-Continued.

[Sample identifier: see figure 35 for the location of sites sampled as part of this study. Contributing aquifer: B, bedrock; LB, Lake Bonneville; PLB, pre-Lake Bonneville; SP, shallow Pleistocene; DP, deep Pleistocene; QT, Quaternary/Tertiary; WU; Western unconsolidated. Dissolved-gas sample method: CT, copper tube; DS, diffusion sampler. A bbreviations: ccSTP/g, cubic centimeters at standard temperature and pressure per gram of water; $\mathrm{NC}$, not calculated; ${ }^{\circ} \mathrm{C}$, degrees Celsius; $\mu \mathrm{g} / \mathrm{L}$, micrograms per liter; —, not analyzed]

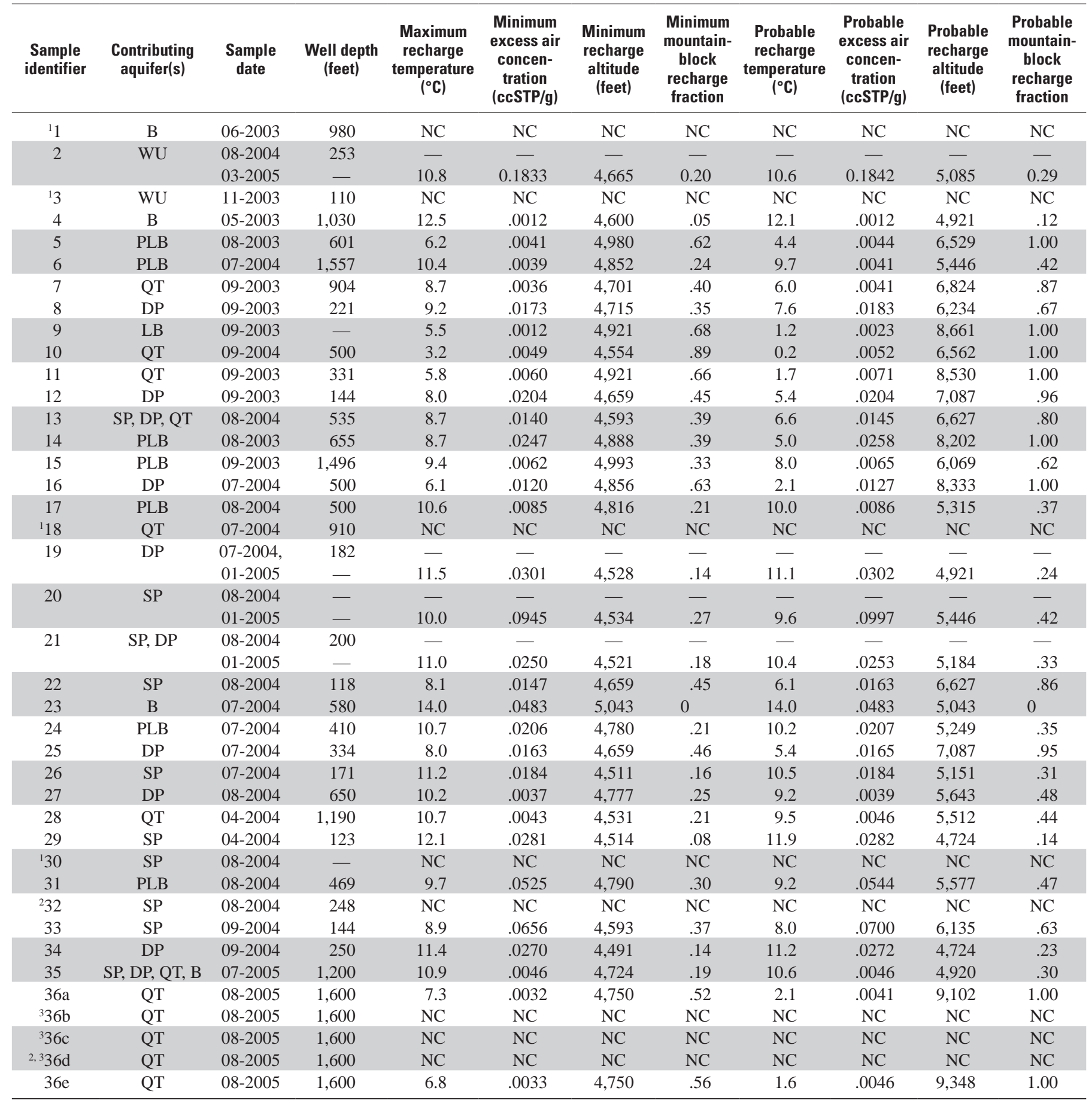

${ }^{1}$ Poor fit to closed-system equilibration model indicated by unreasonably high chi square error. This is likely the result of natural or sample collection gas stripping and results in artificially high recharge temperature.

${ }^{2}$ Sample analysis failed in laboratory due to high mass-spectrometer inlet pressure. Not able to recollect sample.

${ }^{3}$ Attempted to isolate interval of open borehole using packers. Isolation failed and sample was visibly contaminated with drilling fluid. 

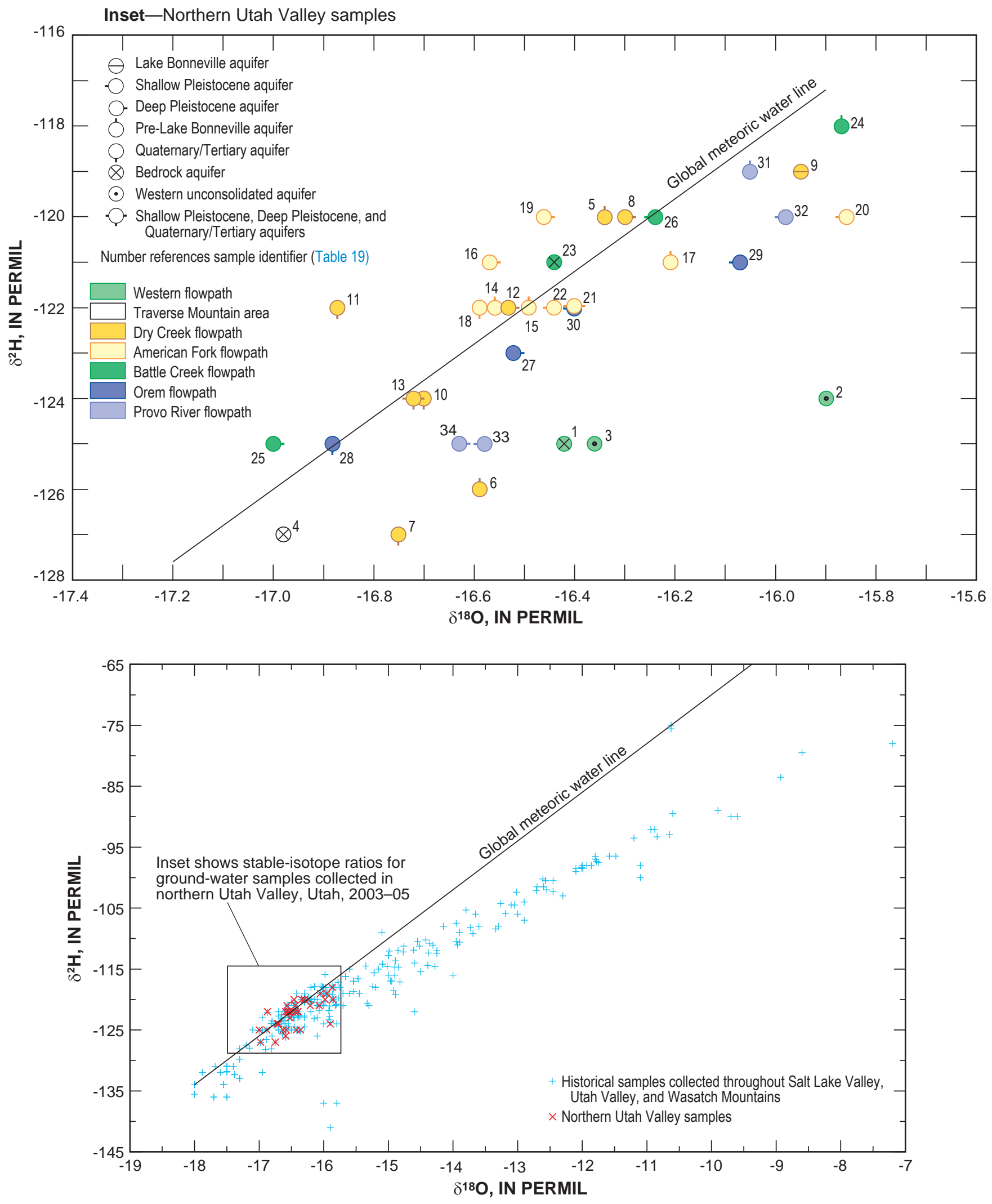

Figure 41. Stable-isotope ratios from ground- and surface-water samples collected throughout Salt Lake Valley, Utah Valley, and the Wasatch Mountains, Utah, 1981-2004. 
diverted from Utah Lake, which is enriched with $\delta^{18} \mathrm{O}$ relative to $\delta \mathrm{D}$ in response to evaporation. The Jacob Canal crosses the primary recharge area and is a recharge source for the WU aquifer. The Utah Lake Distribution Canal traverses the secondary recharge area but may also be a recharge source to the principal basin-fill aquifer (WU) in response to the close proximity of the canals to the primary and secondary rechargearea boundary. The canals are the likely source of evaporated water recharging the WU aquifer in the area. Sample 2 likely represents a mixture of source waters.

\section{Dissolved-Gas Recharge Temperatures}

Dissolved-gas samples were collected and analyzed to evaluate the ground-water recharge temperature $\left(\mathrm{T}_{\mathrm{r}}\right.$, the temperature of water reaching the water table). Most noble gases that are dissolved in ground water originate in the atmosphere. As recharging water enters the aquifer it becomes isolated from the atmosphere and the dissolved-gas concentrations become "fixed" based on their solubility relations to the temperature, pressure, and salinity conditions that exist at the water table (Aeschbach-Hertig and others, 1999; Ballentine and Hall, 1999; Stute and Schlosser, 2001). These gases are generally nonreactive along flowpaths in the subsurface; their dissolved concentrations measured in ground water at points of discharge (wells and springs) provide a record of the physical conditions (temperature and pressure) that are related to the altitude of the ground-water recharge location. In contrast to $\delta^{18} \mathrm{O}$ and $\delta \mathrm{D}$, recharge temperatures can be used to directly evaluate the relative contribution of MBI to basin-fill aquifers (Manning and Solomon, 2003). For shallow water-table depths, $\mathrm{T}_{\mathrm{r}}$ is generally within about $2^{\circ} \mathrm{C}$ of the mean annual air temperature at the location of recharge (Hill, 1990; Dominico and Schwartz, 1998). Mean annual air temperature decreases by about $10.5^{\circ} \mathrm{C}$ per mile of altitude gained in northern Utah (Hely and others, 1971), thus MBI should be distinguishable from valley recharge by its colder $\mathrm{T}_{\mathrm{r}}$. Mountain-front recharge from losing streams in the primary recharge area of northern Utah Valley must pass through a thick unsaturated zone (often hundreds of feet) before reaching the water table. Any variation in the temperature of water in the stream should be attenuated by the time this water crosses the water table and becomes recharge, meaning that mountain-front recharge from losing streams should also have warmer $\mathrm{T}_{\mathrm{r}}$ than $\mathrm{MBI}$ regardless of the variation in stream temperature.

Concentrations of dissolved nitrogen $(\mathrm{N})$, argon-40 $\left({ }^{40} \mathrm{Ar}\right)$, krypton-84 $\left({ }^{84} \mathrm{Kr}\right)$, and neon-20 $\left({ }^{20} \mathrm{Ne}\right)$ were used in a closed system equilibration model (Aeschbach-Hertig and others, 2000; Kipfer and others, 2002) to calculate estimates of ground-water recharge temperature, excess air, and a fractionation factor (related to the partial dissolution of trapped air bubbles $)$. Xenon-129 $\left({ }^{129} \mathrm{Xe}\right)$ was also measured in the five samples collected in the summer of 2005. The three unknown parameters are solved for by optimization of an over-determined system of equations that relates them to the four or five dissolved-gas concentrations measured in each sample. In order to obtain a system of four equations and three unknown variables, the atmospheric pressure at the recharge location (determined by direct correlation with altitude) must be known before the calculation is made. In areas of high topographic relief, the recharge altitude (thus pressure) is not generally known. Manning and Solomon (2003) present a detailed description of the method by which the maximum $\mathrm{T}_{\mathrm{r}}\left(\mathrm{T}_{\mathrm{rmax}}\right)$ and probable $\mathrm{T}_{\mathrm{r}}\left(\mathrm{T}_{\text {rprob }}\right)$ were calculated for samples from wells in nearby Salt Lake Valley. The approach relies on determining a solution zone in recharge-altitude/recharge-temperature space by using valley water-table temperature measurements and $\mathrm{T}_{\mathrm{r}}$ data from mountain springs with constrained recharge elevations. Assuming that water-table temperatures in the mountains and valleys of Utah County are similar to those in Salt Lake County, this approach was used in this study to determine $\mathrm{T}_{\text {rmax }}$ and $\mathrm{T}_{\text {rprob }}$ for water from the wells and springs sampled in northern Utah Valley. With this method, the uncertainty in calculated values of $\mathrm{T}_{\mathrm{r}}$ is approximately plus or minus $1^{\circ} \mathrm{C}$ (Manning and Solomon, 2003).

Dissolved-gas data for water from wells and springs in northern Utah Valley are presented in table 22. Recharge temperatures were calculated for 32 of the 40 samples collected. Dissolved-gas concentrations from eight of the samples appear to have been affected by problems related to sample gas loss. Degassing can occur if the dissolved-gas pressure in the ground water (table 20) is greater than the air pressure at the sampling point, resulting in gases bubbling out of solution. This condition was visibly verified at numerous sampling sites in the valley. When sampling waters with elevated dissolvedgas pressure, it is possible to prevent the loss of gas by collecting the sample in a flow-through chamber designed to apply sufficient back-pressure such that the gas remains in solution (no bubbles form). Another possible explanation for problem samples collected in copper tubes (samples 1, 3, and 18) is gas stripping. Gas stripping occurs when a small air bubble is trapped in the copper tube, causing gases dissolved in the water sample to partition to the bubble prior to laboratory analysis. Measured gas concentrations are artificially low in both of these cases and result in unreasonably high values of $\mathrm{T}_{\mathrm{r}}$ (gases have reverse solubility; lower dissolved-gas concentrations cause a sample to have a higher calculated $\mathrm{T}_{\mathrm{r}}$ ). These errors are recognized when the measured gas concentrations do not yield a reasonable fit (low chi-squared error) to the closed-system equilibration model.

Excess air (atmospheric gases dissolved in ground water in excess of atmospheric solubility) is likely responsible for the atypically high dissolved-gas pressures present in many of the ground-water samples collected from northern Utah Valley. The bedrock and primary recharge areas in northern Utah Valley are unconfined areas in the mountains and near the mountain front where the water table rises rapidly in response to annual recharge from spring snowmelt runoff. Under these conditions, air trapped in pore spaces is likely dissolved by increased hydrostatic pressure adding the excess-air component of the total dissolved-gas concentration. Increased excess 
air and the resulting increases in dissolved-gas concentrations, if not corrected, would result in cooler apparent $T_{r}$ values rather than actual temperatures at the water table.

Dissolved-gas samples collected during this study are from springs and wells that likely receive contributions from a mixture of ground water from a variety of flowpaths. This provides the opportunity to estimate the fractions of MBI and valley recharge contained in each sample. Minimum and probable fractions of MBI were determined by using $\mathrm{T}_{\mathrm{rmax}}$ and $\mathrm{T}_{\text {rprob}}$, respectively, as targets for simple two-component mixing between MBI and valley recharge (note that maximum recharge temperatures $T_{\text {rmax }}$ are used to calculate minimum fractions of MBI). Valley water-table temperatures, measured in shallow wells in Salt Lake Valley, are generally 12 to $14^{\circ} \mathrm{C}$ and mountain springs in the central Wasatch Range have $\mathrm{T}_{\mathrm{r}}$ values ranging from 0 to $10^{\circ} \mathrm{C}$ (Manning and Solomon, 2003). Minimum MBI fractions were calculated assuming a temperature of $13^{\circ} \mathrm{C}$ for the valley recharge component and a $\mathrm{T}_{\mathrm{r}}$ of $2^{\circ} \mathrm{C}$ for the MBI component. Probable MBI fractions were calculated assuming the same $13^{\circ} \mathrm{C}$ temperature for valley recharge and a more likely mean $\mathrm{T}_{\mathrm{r}}$ of $5^{\circ} \mathrm{C}$ for the MBI component.

Maximum recharge temperatures of ground water in the eastern part of the valley are between 3.2 and $14^{\circ} \mathrm{C}$ and in most areas are less than $12^{\circ} \mathrm{C}$ (fig. 42 ), indicating that MBI constitutes a substantial fraction of ground water throughout the valley. The lowest $\mathrm{T}_{\text {rmax }}$ values $\left(3.2\right.$ to $\left.8.7^{\circ} \mathrm{C}\right)$ and the corresponding largest minimum fractions of MBI $(0.39$ to 0.89, fig. 43) extend west-southwestward from the mouth of American Fork Canyon, across the Highland Bench, beyond Lehi. Samples 4 and 35 are located in the area where the Jordan River flows through a gap in the Traverse Mountains and have warmer $\mathrm{T}_{\mathrm{r}}$ values $\left(12.5\right.$ and $\left.10.9^{\circ} \mathrm{C}\right)$ and lower minimum MBI fractions (0.05 and 0.19) than the zone of high MBI that extends southwestward from the mouth of American Fork Canyon. The zone of high MBI can be explained by clear changes in bedrock geology in the mountain block adjacent to this area. The contact between low-permeability igneous rocks that make up much of the mountain block north of the Dry Creek drainage basin and highly-fractured and faulted quartzites and limestones is north of American Fork Canyon (Hintze and others, 2000). South of American Fork Canyon, less-fractured limestone and shale predominates in the mountain block.

South of American Fork Canyon, in the areas of Pleasant Grove and Lindon, $\mathrm{T}_{\mathrm{rmax}}$ values are higher $\left(10\right.$ to $\left.14^{\circ} \mathrm{C}\right)$ (fig. 42) and minimum MBI fractions are mostly less than about 0.25 (fig. 43). Potentiometric contours determined from water levels measured in the SP aquifer (fig. 26) indicate somewhat convergent ground-water flow (from the north and south) in this area indicating that, on the whole, less recharge is occurring here. Although it is possible that a larger fraction of ground water in the Pleasant Grove/Lindon area originates from valley sources such as stream seepage and canal loss close to the mountain front, the areal extent of the primary recharge area is locally small here, and infiltration of unconsumed irrigation water is assumed to be negligible. Estimates of seepage from Battle and Grove Creeks combined with loss from the Provo Reservoir Canal along this stretch do not amount to more than an estimated 5,000 acre-ft/yr. Estimates of MBI along this stretch of the mountain front range from $7,300 \mathrm{acre}-\mathrm{ft} / \mathrm{yr}$ determined from the net-infiltration model (table 12) to 21,700 acre-ft/yr determined from hydraulic gradients in the area (Clark and Appel, 1985, table 8; also see "Tritium and Apparent Ground-Water Age" section of this report). These estimates imply that MBI in this area should constitute as large a fraction to the total recharge as it does to the north near the mouth of American Fork Canyon. One explanation for this discrepancy is that $T_{r}$ is warmer in the mountain block here than in the drainage basins to the north. This could be the result of more MBI occurring at lower altitudes where $\mathrm{T}_{\mathrm{r}}$ is warmer, such that using $2^{\circ} \mathrm{C}$ for the $\mathrm{MBI}$ end member in the mixing calculations underestimates the minimum fraction of MBI in these samples. An isolated, shallowsloped basin (Sagebrush Flat) exists in the mountains east of the Pleasant Grove area (below the west slope of Mount Timpanogos) that is likely the source of MBI to this part of the valley. Much of this basin is at an altitude of 6,500 to 7,500 ft, where $\mathrm{T}_{\mathrm{r}}$ is probably between 6 and $8^{\circ} \mathrm{C}$. The minimum MBI fraction throughout the central part of northern Utah Valley should be considered to be at the extreme low end of the possible range.

Dissolved-gas data generally indicate that water in the QT aquifer throughout northern Utah Valley is nearly all derived from MBI and that mixing with recharge from the Sagebrush Flat area likely accounts for the apparent low MBI fraction in the Geneva area wells. Cooler $\mathrm{T}_{\text {rmax }}$ values exist in two wells (samples 31 and 33) located along the Provo River, indicating a larger fraction of MBI downstream from the mouth of Provo Canyon. Minimum MBI fractions for samples 31 and 33 are 0.30 and 0.37 , respectively, while sample 34 had a minimum MBI fraction of only 0.14. Sample 34 was collected from a 235-ft-deep flowing well open to the DP aquifer that is located just south of and on the opposite side of the Provo River from the well that sample 33 was collected from, which is open to the SP aquifer from 136 to 144 $\mathrm{ft}$ below land surface. When two wells are located in close proximity, water in the deeper well is generally expected to have originated from farther away and from a higher altitude in the ground-water flow system. Recharge that originated at higher altitude should have a colder $\mathrm{T}_{\mathrm{r}}$; yet sample 34 (from a well completed in the deeper aquifer) has a warmer $\mathrm{T}_{\text {rmax }}$ and a lower MBI fraction. Both of these wells are located near the terminal end of the basin-fill ground-water flow system where flowpaths converge toward points of discharge. The differing $\mathrm{T}_{\text {rmax }}$ values (8.9 and $11.4^{\circ} \mathrm{C}$ ) and MBI fractions may reflect the heterogeneity that exists in sources of water (fractions of MBI versus valley recharge) along the mountain front. Analysis of stable isotope and major-ion chemistry data is incapable of distinguishing between source waters in this area because nearly all of the ground water originated as precipitation over the Wasatch Mountains (yielding similar $\delta \mathrm{D}$ and $\delta^{18} \mathrm{O}$ values for MBI and stream seepage that occurs at the mountain front) and traveled through similar bedrock and sediment (resulting 


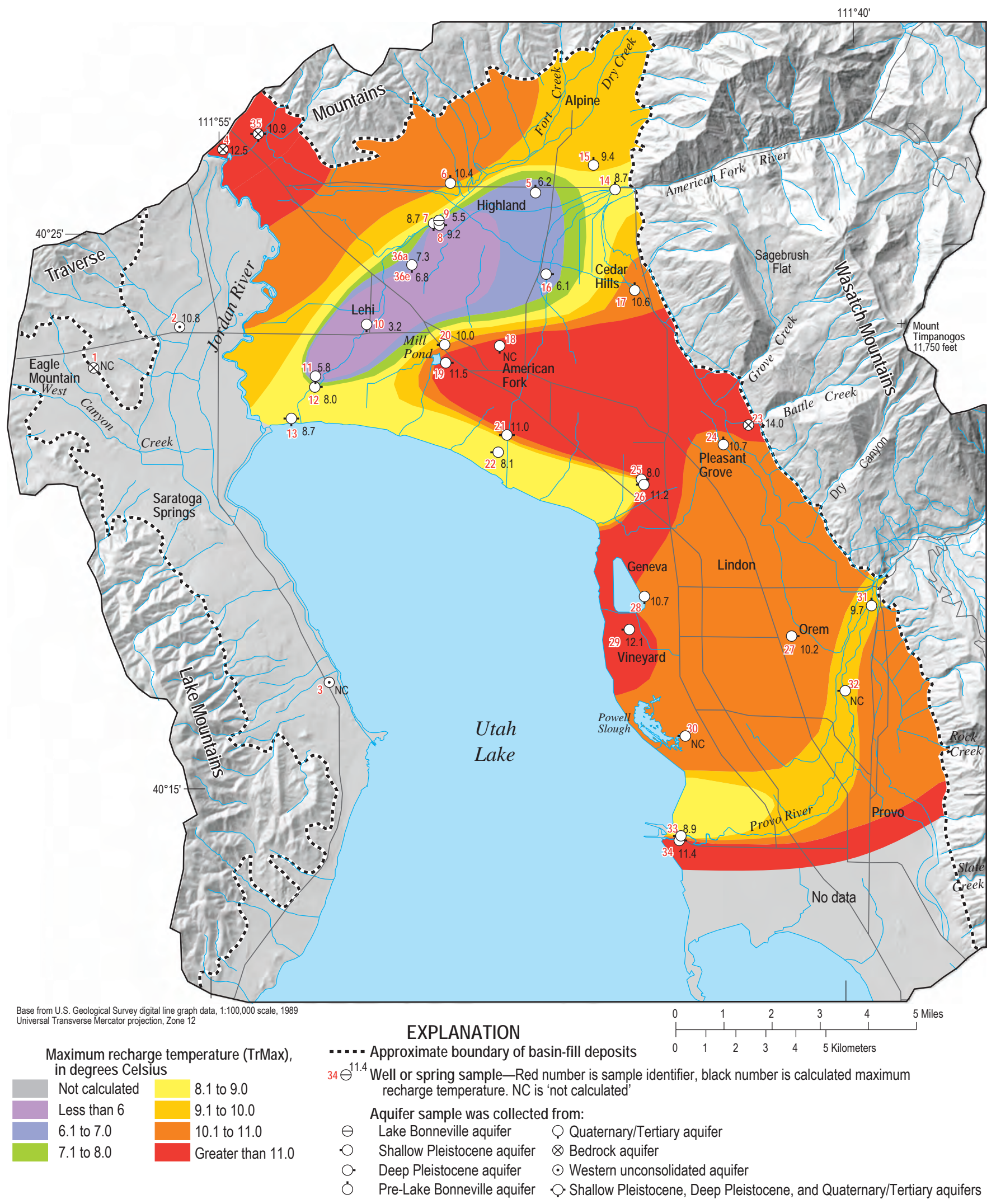

Figure 42. Distribution of maximum recharge temperatures for ground water sampled in northern Utah Valley, Utah, $2003-05$. 


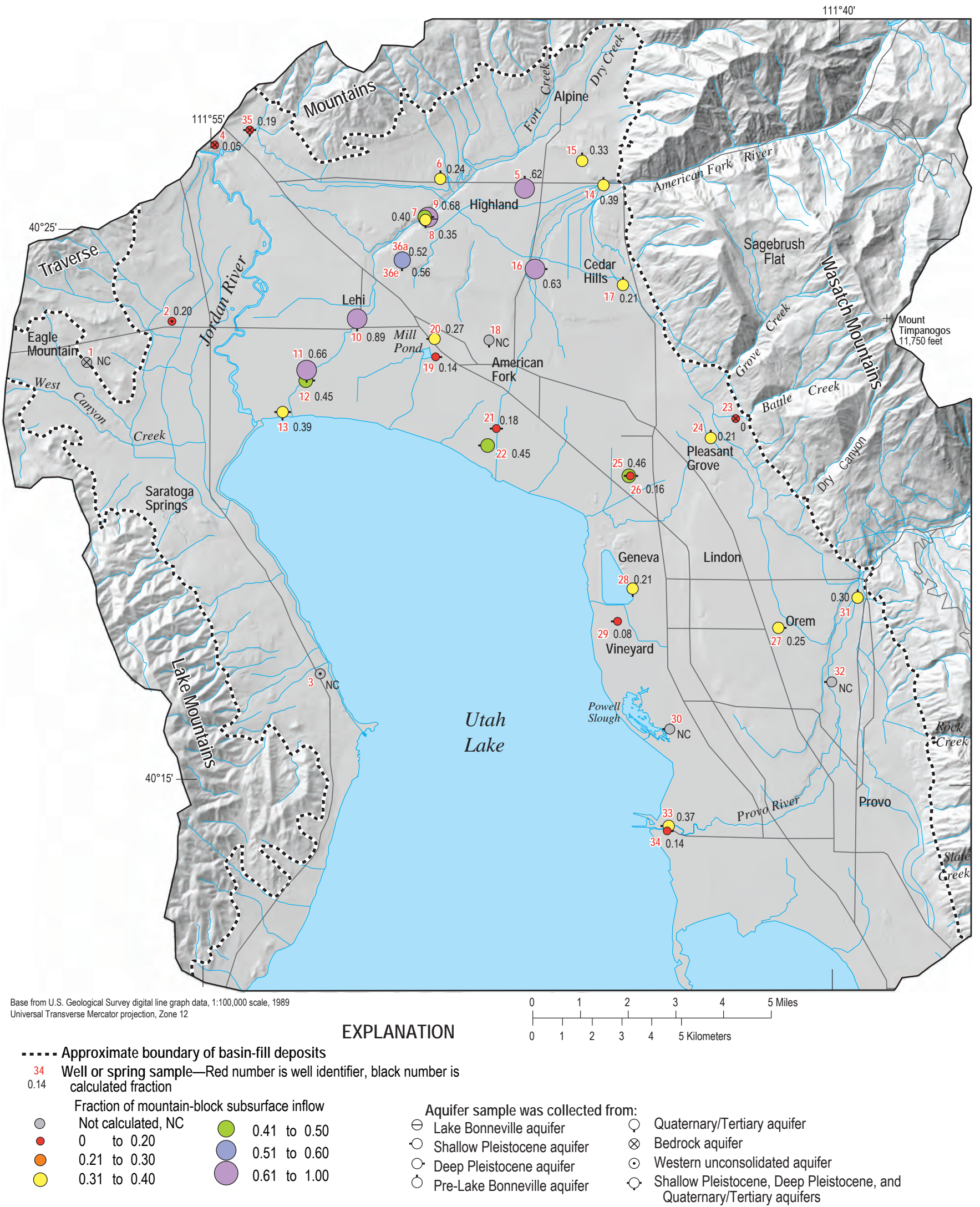

Figure 43. Distribution of minimum fraction of mountain-block subsurface inflow for ground water sampled in northern Utah Valley, Utah, 2003-05. 
in similar major-ion chemical signatures). Dissolved-gas data, however, indicate that the shallower SP aquifer north of the Provo River contains a higher fraction of MBI than the deeper DP aquifer south of the river.

Other ground-water samples collected near Utah Lake (samples 21, 25, 26, 28, and 29) show a pattern of warmer $\mathrm{T}_{\mathrm{r}}$ values in wells that are open at shallower depths. This pattern is expected because recharge from higher in the mountain block would take the longer and deeper flowpath toward the natural discharge point in the basin (fig. 3). Samples 25 and 26 were collected from adjacent wells completed in the DP and SP aquifers, respectively. The water level measured in the DP aquifer well was more than $1 \mathrm{ft}$ higher than that of the SP aquifer well in March 2004, indicating an upward gradient between the aquifers in this area. This also occurs in other wells that are near each other but completed in different aquifers (samples 21 and 22, samples 28 and 29). The SP aquifer may receive a mixture of water with colder $T_{r}$ from the deeper confined basin-fill aquifers and water with warmer $T_{r}$ that originated as recharge in the valley.

Recharge temperature was only calculated for water from one location (sample 2) west of the Jordan River. Stable isotope data indicate that this well likely contains some evaporated recharge from canal seepage. The $\mathrm{T}_{\text {rmax }}$ of $10.8^{\circ} \mathrm{C}$ and minimum MBI fraction of 0.20 from this sample are consistent with the source of this water being a mixture of lower-altitude MBI from the western Traverse Mountains (greater than 6,000 $\mathrm{ft}$ in altitude) and seepage from irrigated fields and irrigation canals located upgradient of the well.

Two samples near the Jordan Narrows (samples 4 and $35)$ were collected from wells open to fractured bedrock at more than 1,000 ft below land surface. Stable-isotope values of water in sample 4 are the lightest of any analyzed for this study ( $\delta \mathrm{D}$ and $\delta^{18} \mathrm{O}$ equal -127 and -16.98 , respectively), indicating that higher-altitude $\mathrm{MBI}$ is the source of water to these wells. However, the $\mathrm{T}_{\text {rmax }}$ values $\left(12.5\right.$ and $\left.10.9^{\circ} \mathrm{C}\right)$ are higher than expected for higher-altitude MBI. The relatively warm $T_{r}$ values could be the result of a deep mountain water table in the MBI source area or of precipitation that falls very high in the mountain block but then runs off during snowmelt and recharges the bedrock at a lower altitude. Deep watertable temperatures should be controlled more by the local geothermal gradient than by the mean annual air temperature and anomalously high geothermal gradients (45 to more than $500^{\circ} \mathrm{C}$ per kilometer) that have been observed in boreholes near this area (Blackett and Wakefield, 2004, fig. 1). Both of these samples contain elevated concentrations of terrigenic helium-4 $\left({ }^{4} \mathrm{He}\right.$ ) (more than about $5 \times 10^{-8} \mathrm{ccSTP} / \mathrm{g}$; see "Tritium and Apparent Ground-Water Age" section of this report). Terrigenic ${ }^{4} \mathrm{He}$ originates from the radioactive decay of naturally occurring uranium- and thorium-series elements in aquifer solids and has been used to date ground water that is 1,000 to $1,000,000$ years old (Solomon and Cook, 2000). Although precise dating of ground water by using terrigenic ${ }^{4} \mathrm{He}$ is beyond the scope of this study, concentrations in these samples likely have a minimum age of thousands of years. On the basis of these data, water from these bedrock wells may be older than water from basin-fill wells even though the dissolved-gas temperature was not very cool. Recharge to the bedrock aquifer near the Jordan Narrows may have occurred in an area of the surrounding Traverse Mountains where the water table is deep, causing dissolved-gas recharge temperatures to be warm, at a time in the past when the climate was cooler, resulting in a more-depleted isotopic signature and elevated ${ }^{4} \mathrm{He}$.

Dissolved-gas recharge temperature data throughout northern Utah Valley generally support the conceptual model and highlight the complexities of recharge patterns in different parts of the valley. Minimum MBI fractions agree well with patterns of previous MBI estimates (Clark and Appel, 1985, table 8 and fig. 9), showing the highest MBI contributions to the basin-fill aquifers occurring downstream from the mouths of American Fork and Provo Canyons. These data also show that MBI constitutes a large fraction of the total source of water to the basin-fill aquifers.

\section{Tritium and Apparent Ground-Water Age}

Tritium $\left({ }^{3} \mathrm{H}\right)$ is a radioactive isotope of hydrogen that decays to tritiogenic helium-3 $\left({ }^{3} \mathrm{He}_{\text {trit }}\right)$ with a half-life of 12.3 years. Tritium is produced in the upper atmosphere and occurs naturally in precipitation at concentrations of less than about 8 tritium units (TU) in northern Utah. Testing of above-ground thermonuclear weapons in the 1950s and 1960s was the source for ${ }^{3} \mathrm{H}$ concentrations in precipitation that peaked at more than $1,000 \mathrm{TU}$ in the northern hemisphere. The ratio of ${ }^{3} \mathrm{H}$ to ${ }^{3} \mathrm{He}$ trit yields the apparent age (time since recharge occurred) of a ground-water sample according to the following equation:

$$
t=\lambda^{-1} \ln \left({ }^{3} \mathrm{He} e_{\text {trit }} /{ }^{3} \mathrm{H}+1\right)
$$

where:

$$
t \quad \text { is the apparent age in years, }
$$

and

$$
\lambda \quad \text { is the }{ }^{3} \mathrm{H} \text { decay constant of } 0.0563 \text { per year. }
$$

The ${ }^{3} \mathrm{H} /{ }^{3} \mathrm{He}$ method, used to date water younger than about 50 years, is explained in detail by Solomon and Cook (2000).

The age derived from equation (6) is affected by mixing of waters with different ages and for that reason is referred to as the "apparent age" of a sample. Note that a sample containing a mixture of modern and pre-modern water (where "modern" refers to recharge that occurred during or after the period of above-ground nuclear testing and "pre-modern" refers to recharge occurring before that time) will always appear to have the age of the young fraction because dilution with pre-modern water will leave the ratio of ${ }^{3} \mathrm{H}$ to ${ }^{3} \mathrm{He}_{\text {trit }}$ virtually unchanged.

${ }^{3} \mathrm{H} /{ }^{3} \mathrm{He}$ age data for water from wells and springs in northern Utah valley are presented in table 23 . The ${ }^{3} \mathrm{He}_{\text {trit }}$ concentration was determined from dissolved-gas samples collected at the same sites and apparent ${ }^{3} \mathrm{H} /{ }^{3} \mathrm{He}$ ages were calculated by using the probable recharge temperature and altitude listed in table 22. Uncertainty in the apparent age 
Table 23. Tritium/helium-3 age data for ground water sampled in northern Utah Valley, Utah, 2003-05.

[Sample identifier: see figure 35 for the location of sites sampled as part of this study. Contributing aquifer: B, bedrock; DP, deep Pleistocene; LB, Lake Bonneville; PLB, pre-Lake Bonneville; SP, shallow Pleistocene; QT, Quaternary/Tertiary; WU, Western unconsolidated. Abbreviations: TU, tritium units; R, measured ${ }^{3} \mathrm{He} /{ }^{4} \mathrm{He}$ ratio of the sample; $\mathrm{R}_{\mathrm{a}}$, atmospheric ${ }^{3} \mathrm{He} /{ }^{4} \mathrm{He}$ ratio; ccSTP/g, cubic centimeters at standard temperature and pressure per gram of water; ${ }^{3} \mathrm{He}$ trit, tritiogenic helium-3; NC, not calculated; >, greater than; - , not analyzed]

\begin{tabular}{|c|c|c|c|c|c|c|c|c|c|c|}
\hline \multirow{2}{*}{$\begin{array}{l}\text { Sample } \\
\text { identifier }\end{array}$} & \multirow{2}{*}{$\begin{array}{l}\text { Contributing } \\
\text { aquifer(s) }\end{array}$} & \multirow{2}{*}{$\begin{array}{l}\text { Tritium } \\
\text { (TU) }\end{array}$} & \multirow{2}{*}{$\mathbf{R} / \mathbf{R}_{\mathbf{a}}$} & \multicolumn{2}{|c|}{ Terrigenic } & \multirow{2}{*}{$\begin{array}{l}{ }^{3} \mathrm{He}_{\text {trit }} \\
\text { (TU) }\end{array}$} & \multirow{2}{*}{$\begin{array}{l}\text { Apparent } \\
\text { age } \\
\text { (years) }\end{array}$} & \multirow{2}{*}{$\begin{array}{c}\text { Apparent } \\
\text { recharge } \\
\text { year }\end{array}$} & \multirow{2}{*}{$\begin{array}{l}\text { Initial tri- } \\
\text { tium (TU) }\end{array}$} & \multirow{2}{*}{$\begin{array}{l}\text { Interpreted } \\
\text { age } \\
\text { category }\end{array}$} \\
\hline & & & & ${ }^{4} \mathrm{He}$ (ccSTP/g) & ${ }^{3} \mathrm{He} /{ }^{4} \mathrm{He}$ ratio & & & & & \\
\hline 2 & WU & 5.7 & .89 & $2.49 \mathrm{E}-08$ & 2.77E-08 & 9.5 & 18 & 1986 & 15 & Modern \\
\hline 3 & WU & .5 & .13 & $1.10 \mathrm{E}-05$ & $1.80 \mathrm{E}-07$ & 6.5 & 48 & 1955 & 7 & Pre-modern \\
\hline 6 & PLB & 0 & .87 & $1.33 \mathrm{E}-08$ & 2.77E-08 & 2.5 & $>50$ & pre-1950 & 3 & Pre-modern \\
\hline 7 & QT & .1 & .75 & 2.34E-08 & 2.77E-08 & 1.5 & 50 & 1954 & 2 & Pre-modern \\
\hline 8 & DP & 10.1 & 1.37 & $-1.59 \mathrm{E}-11$ & 2.77E-08 & 12.8 & 15 & 1989 & 23 & Modern \\
\hline 9 & LB & 8.9 & 1.05 & $-5.03 \mathrm{E}-10$ & 2.77E-08 & 1.1 & 2 & 2001 & 10 & Modern \\
\hline 10 & QT & 1.3 & 1.27 & 2.77E-09 & 2.77E-08 & 11.7 & 42 & 1963 & 13 & Pre-modern \\
\hline 11 & QT & .2 & .94 & $9.06 \mathrm{E}-09$ & 2.77E-08 & 2.4 & 46 & 1957 & 3 & Pre-modern \\
\hline 16 & $\mathrm{DP}$ & 8.1 & 1.24 & $2.05 \mathrm{E}-09$ & 2.77E-08 & 12.2 & 16 & 1988 & 20 & Modern \\
\hline 17 & PLB & 8.4 & 1.19 & $1.92 \mathrm{E}-08$ & 2.77E-08 & 18.4 & 21 & 1983 & 27 & Modern \\
\hline 18 & QT & 12.8 & 3.33 & $5.49 \mathrm{E}-09$ & 2.77E-08 & 101.4 & 39 & 1965 & 114 & Modern or mixture \\
\hline 19 & DP & 16.7 & 2.48 & 2.81E-09 & 2.77E-08 & 74.4 & 30 & 1974 & 91 & Modern \\
\hline 20 & SP & 9.7 & 1.34 & $7.34 \mathrm{E}-10$ & 2.77E-08 & 10.0 & 13 & 1991 & 20 & Modern \\
\hline 21 & SP, DP & 14.6 & 3.11 & $2.94 \mathrm{E}-09$ & 2.77E-08 & 76.3 & 33 & 1971 & 91 & Modern \\
\hline 22 & SP & 14.0 & 3.11 & 4.53E-09 & 2.77E-08 & 70.1 & 32 & 1972 & 84 & Modern \\
\hline 23 & $\mathrm{~B}$ & 7.8 & .81 & $1.14 \mathrm{E}-07$ & 2.77E-08 & 33.4 & 30 & 1974 & 41 & Modern or mixture \\
\hline 24 & PLB & 11.1 & 1.23 & 4.71E-09 & 2.77E-08 & 10.0 & 12 & 1993 & 21 & Modern \\
\hline 25 & DP & .1 & .94 & $1.26 \mathrm{E}-08$ & 2.77E-08 & 4.4 & $>50$ & pre-1950 & 4 & Pre-modern \\
\hline 26 & SP & 13.0 & 2.32 & $1.80 \mathrm{E}-09$ & 2.77E-08 & 52.9 & 29 & 1975 & 66 & Modern \\
\hline 34 & DP & 11.2 & .57 & 3.71E-07 & 2.77E-08 & 100.2 & 41 & 1963 & 111 & Modern or mixture \\
\hline 35 & SP, DP, QT, B & .1 & .15 & 7.90E-06 & $1.91 \mathrm{E}-07$ & 4.1 & $>50$ & pre-1950 & 4 & Pre-modern \\
\hline${ }^{2} 36 \mathrm{a}$ & QT & 3.7 & .96 & $1.96 \mathrm{E}-08$ & 2.77E-08 & 9.2 & 22 & 1983 & 12 & Modern or mixture \\
\hline${ }^{3} 36 \mathrm{~b}$ & QT & 7.2 & .46 & $9.88 \mathrm{E}-08$ & $2.77 \mathrm{E}-08$ & $\mathrm{NC}$ & $\mathrm{NC}$ & $\mathrm{NC}$ & $\mathrm{NC}$ & $\mathrm{NC}$ \\
\hline${ }^{3} 36 \mathrm{c}$ & QT & 3.8 & .41 & $1.24 \mathrm{E}-07$ & 2.77E-08 & $\mathrm{NC}$ & $\mathrm{NC}$ & $\mathrm{NC}$ & $\mathrm{NC}$ & $\mathrm{NC}$ \\
\hline${ }^{3} 36 \mathrm{~d}$ & QT & 5.1 & - & - & - & - & - & - & - & $\mathrm{NC}$ \\
\hline $36 \mathrm{e}$ & QT & .4 & .20 & $6.15 \mathrm{E}-07$ & $1.66 \mathrm{E}-07$ & 4.1 & 42 & 1963 & 5 & Pre-modern \\
\hline
\end{tabular}

${ }^{1}$ Measured tritium concentration greater than $3 \mathrm{TU}$ indicates that the sample contains at least some fraction of modern water.

${ }^{2}$ Calculated maximum recharge temperature value is low (table 22) and similar to deepest sampled interval at this well (sample 36 e). This suggests that the tritium in this water is not due to contamination.

${ }^{3}$ Attempted to isolate interval of open borehole using packers. Isolation failed and sample was visibly contaminated with drilling fluid. 
is most affected by the terrigenic ${ }^{4} \mathrm{He}\left({ }^{4} \mathrm{He} e_{\text {terr }}\right)$ concentration (Plummer and others, 2000; Holocher and others, 2001). Terrigenic ${ }^{3} \mathrm{He}$ along with ${ }^{4} \mathrm{He}$ is produced by the subsurface decay of naturally occurring uranium- and thorium-series elements in aquifer solids. The ratio of terrigenic ${ }^{3} \mathrm{He}$ to ${ }^{4} \mathrm{He}$ produced varies and is poorly constrained. Because this ratio is used to determine the terrigenic component of ${ }^{3} \mathrm{He}$ and ultimately to calculate ${ }^{3} \mathrm{He}_{\text {trit }}$, the apparent age of samples with elevated levels of ${ }^{4} \mathrm{He}_{\text {terr }}$ (more than about $5 \times 10^{-8} \mathrm{ccSTP} / \mathrm{g}$ ) is subject to greater uncertainty. The terrigenic ${ }^{3} \mathrm{He} /{ }^{4} \mathrm{He}$ ratio was adjusted for samples with low ${ }^{3} \mathrm{H}$ concentrations and elevated ${ }^{4} \mathrm{He}_{\text {terr }}$ concentrations until the ${ }^{3} \mathrm{He}_{\text {trit }}$ approximated known pre-1950s levels of less than $8 \mathrm{TU}$. The uncertainty in the apparent age resulting from the uncertainty in the recharge temperature and altitude combined with analytical uncertainty is plus or minus 3 years for samples with ${ }^{4} \mathrm{He}_{\text {terr }}$ concentrations less than about $5 \times 10^{-8} \mathrm{ccSTP} / \mathrm{g}$ (Manning, 2002, appendix B). Samples with higher concentrations of ${ }^{4} \mathrm{He}_{\text {terr }}$ have higher uncertainties and can only reliably be classified as "pre-modern."

${ }^{3} \mathrm{H} /{ }^{3} \mathrm{He}$ age data for this study were analyzed and categorized as in Thiros and Manning (2004) for samples from nearby Salt Lake Valley. Samples were categorized as (1) modern, (2) modern or mixture, and (3) pre-modern (table 23) by examining their measured ${ }^{3} \mathrm{H}$ concentration and comparing their initial ${ }^{3} \mathrm{H}$ (measured ${ }^{3} \mathrm{H}$ plus measured ${ }^{3} \mathrm{He}_{\text {trit }}$ ) to that of local precipitation at the time of recharge. Unmixed modern water samples should have an initial ${ }^{3} \mathrm{H}$ concentration approximately equal to the concentration in precipitation at the time of recharge (apparent recharge year, table 23). Samples containing a mixture of modern and pre-modern water will have an initial ${ }^{3} \mathrm{H}$ concentration of less than the concentration in precipitation for the apparent recharge year. The initial ${ }^{3} \mathrm{H}$ concentration in water samples from northern Utah Valley is plotted with the mean annual ${ }^{3} \mathrm{H}$ concentration in precipitation in Salt Lake City from 1953 to 2000 in figure 44. Mean annual ${ }^{3} \mathrm{H}$ concentrations in precipitation are derived from monthly data available for most of 1963 to 1984 for Salt Lake City (International Atomic Energy Agency, 2007). Mean annual ${ }^{3} \mathrm{H}$ concentrations prior to 1963 and after 1984 were estimated by correlation with ${ }^{3} \mathrm{H}$ concentrations in precipitation from Ottawa, Canada (International Atomic Energy Agency, 2007). Waters plotting near the precipitation line in figure 44 are categorized as modern and their apparent age should approximate the flow-weighted mean age of the sample. Waters containing less than $2 \mathrm{TU}$ are categorized as pre-modern and waters that contain more than $2 \mathrm{TU}$ that plot below the precipitation line in figure 44 are categorized as modern or a mixture of modern and pre-modern water. Note that these waters may be a mixture of modern water of different ages. Waters containing elevated ${ }^{4} \mathrm{He}_{\text {terr }}$ concentrations (greater than about $5 \times 10^{-8}$ ccSTP/g) are distinguished from those with low ${ }^{4} \mathrm{He}_{\text {terr }}$ concentrations in figure 44 because the apparent age and initial ${ }^{3} \mathrm{H}$ concentrations in these samples are less certain. Samples 29, 33 , and 34 are categorized as modern or mixture, even though they plot near the precipitation line. Both of these samples contain elevated ${ }^{4} \mathrm{He}_{\text {terr }}$ concentrations, meaning that they both contain a fraction of pre-modern water that is very old (more than 1,000 years old and possibly much older) and that their initial ${ }^{3} \mathrm{H}$ concentrations are uncertain and may actually be less than what is shown. The high concentrations of both ${ }^{3} \mathrm{H}$ and ${ }^{4} \mathrm{He}_{\text {terr }}$ in these waters from the SP and DP aquifers indicate areas where modern water that likely originated as mountainfront recharge is mixing with upwelling pre-modern water from the QT aquifer in the discharge area. These are areas of focused discharge where a variety of flowpaths are converging. Samples from other wells in the discharge area do not have this signature; they are either collected from deep wells with clearly pre-modern water (samples $10,11,13$, and 28) or from shallower wells with modern water (samples 19, 20, 21, and 22) (figs. 44 and 45). The only other exception in the discharge area is sample 12, which plots below the precipitation line in figure 44 , indicating it to be a mixture, but does not have the high concentrations of ${ }^{4} \mathrm{He}_{\text {terr }}$ present where very old ground water is upwelling from the QT aquifer. This sample is probably a mixture of modern water with water that, although too old to be dated with ${ }^{3} \mathrm{H}$, is much younger than the premodern fraction in samples 29,33, and 40.

${ }^{3} \mathrm{H} /{ }^{3} \mathrm{He}$ age data are useful for delineating patterns of ground-water flow. The distribution of apparent ${ }^{3} \mathrm{H} /{ }^{3} \mathrm{He}$ age and interpreted age category for ground water sampled in northern Utah Valley (table 23) is shown in figure 45. Apparent ages range from 2 to more than 50 years and their distribution is in good agreement with the conceptual model of the flow system. The youngest waters on the eastern side of the valley occur near the mountain front, and ages generally increase toward the discharge area and Utah Lake. Samples 15 and 23 are exceptions to this pattern. These samples have apparent ages of 35 and 30 years, respectively, and were collected from wells located near the mountain front. Both of these wells have deep open intervals (greater than $500 \mathrm{ft}$ below land surface) and are likely capturing a fraction of older MBI.

Interpreted age categories are also in general agreement with minimum MBI fractions determined from dissolved-gas data. Water that originated as high-altitude recharge should experience deep circulation and long travel times. Consequently, samples containing large fractions of MBI should be older than samples that contain mostly valley recharge. This pattern is observed throughout much of the eastern part of northern Utah Valley where MBI makes up a substantial fraction of the recharge. Waters that have some of the highest minimum MBI fractions (samples 10 and 11, table 22) are premodern. Nearly all of the samples categorized as modern or mixtures of modern and pre-modern water in the eastern part of the valley have minimum MBI fractions of 0 to 0.5 , meaning that waters with young apparent ages contain appreciable fractions of water from valley sources. Examples of this are the modern waters present in the SP and DP aquifers in the American Fork area (samples 19, 20, 21, and 22) which likely contain substantial fractions of mountain-front recharge.

Notable inconsistencies were observed in samples 5, 9, and 16, where waters that have cool $\mathrm{T}_{\mathrm{r}}$ and appear to contain substantial MBI (minimum MBI fractions from 0.62 to 0.68 ) 


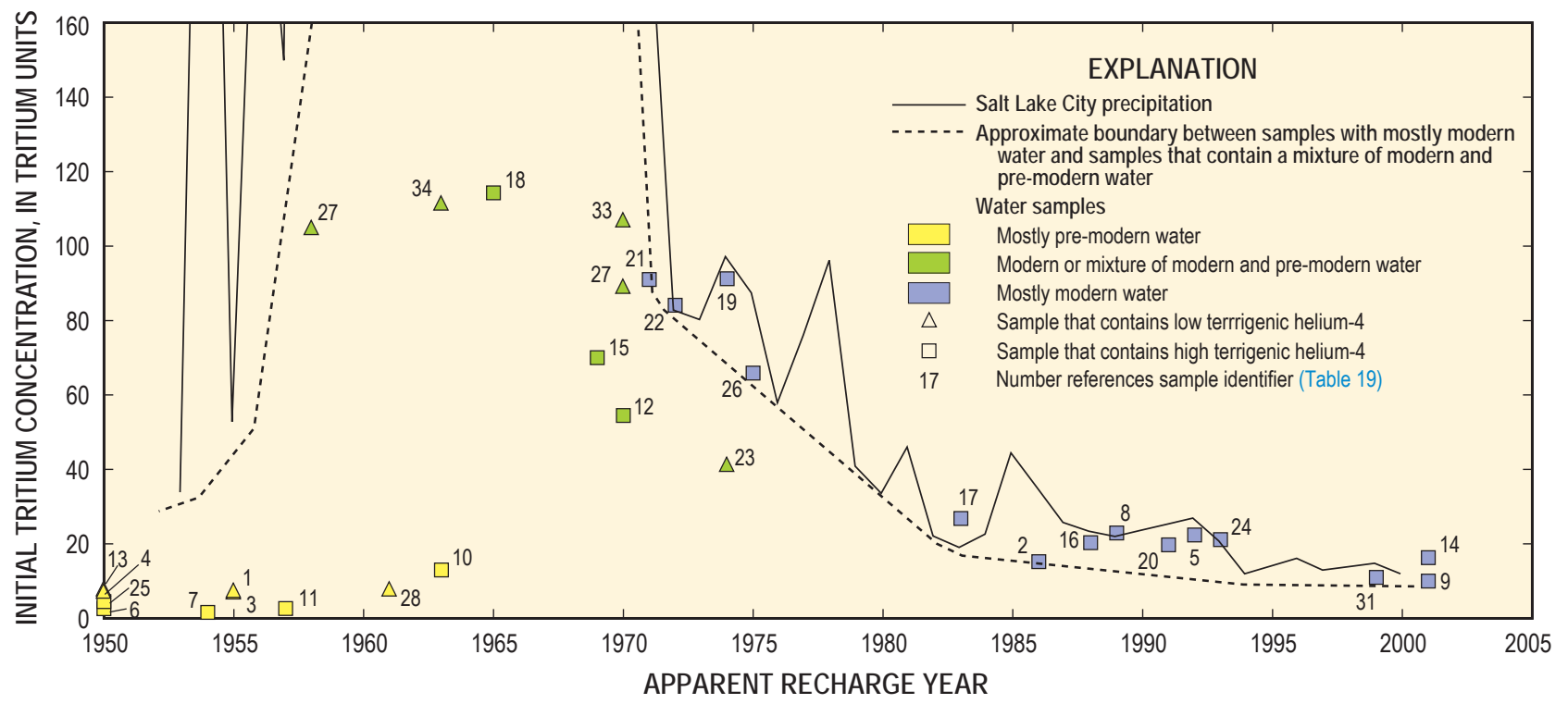

Figure 44. Tritium concentration in precipitation and the relation between initial tritium concentration and apparent recharge year for ground water sampled during 2003-05 in northern Utah Valley, Utah.

also have young apparent ages of 2 to 16 years. Cool $\mathrm{T}_{\mathrm{r}}$ values generally imply recharge derived from high-altitude mountain areas. Sample 9 is spring discharge from a perched aquifer in the Dry Creek/Fort Creek area. This system probably is recharged by spring runoff of snowmelt from these drainage basins in areas where the perched water table is at or near land surface. In this scenario, the snowmelt runoff is not warmed by passing through the unsaturated zone, and winter recharge is expected to have cool $\mathrm{T}_{\mathrm{r}}$ even though it occurred at a low (valley) altitude. The maximum recharge temperature $\left(5.5^{\circ} \mathrm{C}\right.$, table 22) for water from this spring is consistent with spring snowmelt as the source.

A number of scenarios consistent with the local geology could contribute to the combination of young apparent age and cool $\mathrm{T}_{\mathrm{r}}$ in samples 5 and 16. Mountain bedrock east of these samples (in and around American Fork Canyon) is composed of highly fractured rocks, including limestone with well-developed cave systems (Mayo and others, 2000). The presence of these caves is evidence that areas exist around American Fork where the water table is deep. Hydraulic-conductivity values in fractured rocks, gravel, and coarse sands (all the materials through which these waters must travel) can be hundreds of feet per day (Dominico and Schwartz, 1998, table 3.2, p. 39). Ground water moving rapidly through a fractured flow system could deliver MBI to the basin-fill aquifers in the valley in a very short time. In mountainous areas experiencing high rates of cool recharge (such as snowmelt), ground water moving quickly downward through a fractured flow system could result in deep water-table temperatures that are substantially cooler than those predicted by assuming a local atmospheric lapse rate. Under these circumstances, the time it would take for cool MBI to reach wells in the basin-fill aquifers would be greatly reduced.
Apparent ages also may be biased young, even in modern waters, if the water experienced a partial loss of ${ }^{3} \mathrm{He}_{\text {trit }}$. Helium may be removed from the water by degassing or by diffusion into the rock matrix in a fractured system. Helium (a dissolved gas) has a higher diffusion coefficient and is more strongly retarded than ${ }^{3} \mathrm{H}$ (bound to the water molecule) by matrix diffusion in fractured rocks (Cook and others, 1996). Depending on the effectiveness of helium stripping, samples that appear to be less than 16 years old may actually have been recharged in the 1950 s to 1970 s. A combination of these scenarios likely contributes to the paradoxical appearance of samples 5 and 16 (cool $\mathrm{T}_{\mathrm{r}}$ and young apparent age). Further study of the ground water in this area would be required to confirm any of the proposed hypotheses.

Ground-water samples collected in the vicinity of the Jordan Narrows (samples 4 and 35) are essentially free of ${ }^{3} \mathrm{H}$ and have elevated ${ }^{4} \mathrm{He}_{\text {terr }}$, making them clearly pre-modern. Older ground water in this area may be the result of low recharge rates. This is consistent with the idea discussed in the "Dissolved-Gas Recharge Temperatures" section of this report that ground water in this area recharges a deep water table through a thick unsaturated zone, leading to warm $\mathrm{T}_{\mathrm{r}}$, and deeply circulates, leading to long travel times.

Water from a bedrock well in the Cedar Pass area (sample 1) and a well in basin-fill deposits near the western shore of Utah Lake (sample 3) is pre-modern with low ${ }^{3} \mathrm{H}$ (0.5 TU) and elevated ${ }^{4} \mathrm{He}_{\text {terr }}$. Although few data are available west of the Jordan River, these observations agree with the current conceptual model indicating that much of the ground water in these areas is not derived from local sources, but rather enters northern Utah Valley from fractured bedrock in the Cedar Pass area. Sample 2, also located west of the Jordan River, is in an area where infiltration of irrigation water from fields and 


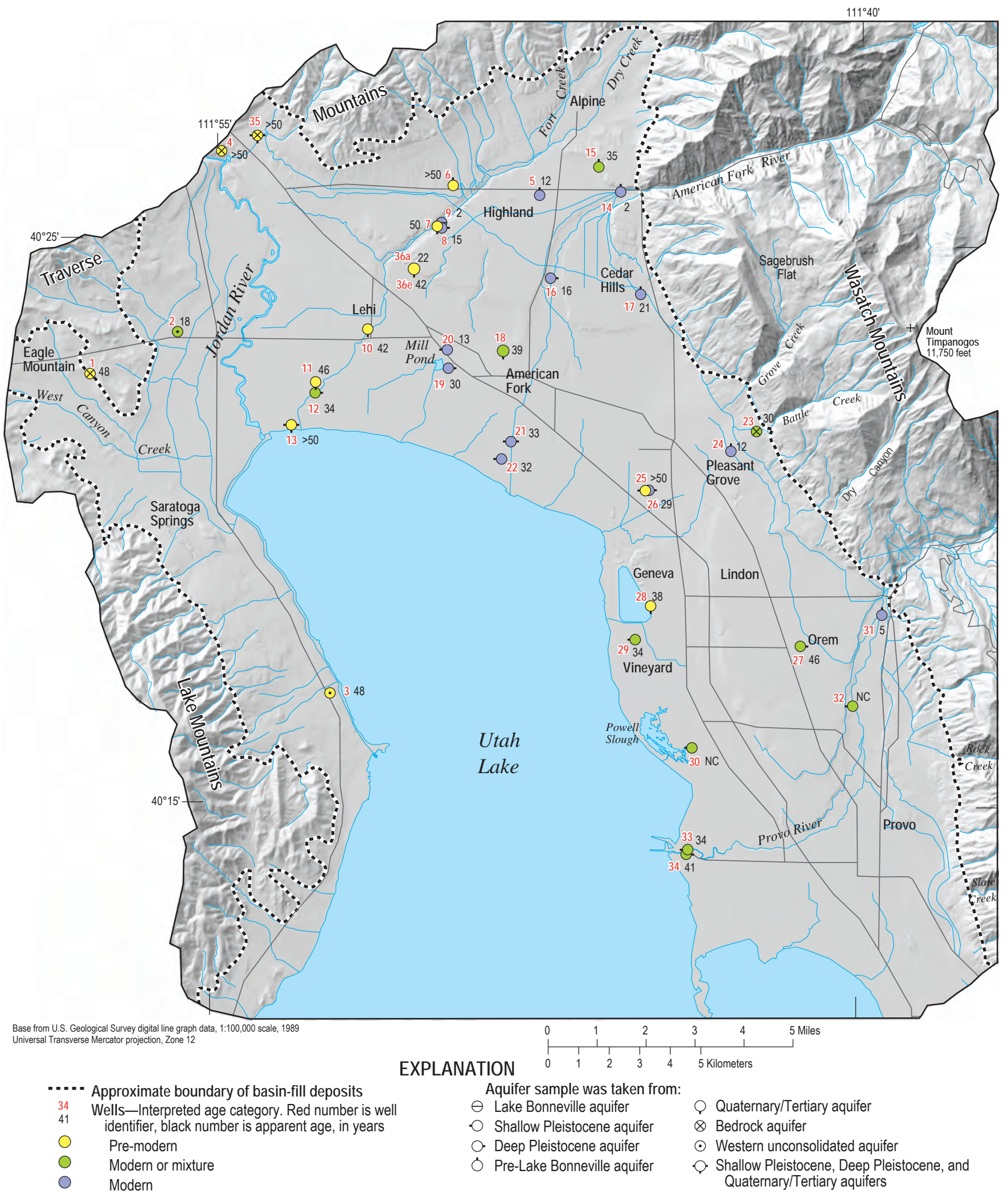

Figure 45. Distribution of apparent tritium/helium-3 age and interpreted age category for ground water sampled in northern Utah Valley, Utah, 2003-05. 
canals is a likely source of recharge. The young component of water in this sample (apparent age of 18 years, fig. 45) combined with an enriched $\delta^{18} \mathrm{O}$ value relative to $\delta \mathrm{D}$ (fig. 41) indicates that recharge to the WU aquifer in this area is from an evaporated source, such as seepage of unconsumed irrigation water or from canals carrying water from Utah Lake.

Waters characterized as modern should not have a substantial young-age bias and should approximate the flowweighted mean age of a sample. Under this assumption, the age gradient can be used to make estimates of recharge with the simple relation:

$$
Q=v n A,
$$

where:

$Q \quad$ is the volumetric flow rate of recharge,

$v \quad$ is the average linear ground-water flow velocity,

$n \quad$ is the average effective porosity,

and

$A \quad$ is the cross-sectional area normal to the flow direction.

Estimates of recharge were made along the eastern margin of the valley where age gradients between sample locations of modern waters were available to estimate average linear ground-water velocities. Velocities were estimated along general flow lines delineated by the potentiometric contours in figure 27 . For all estimates, the value $n=0.2$ was used to represent the effective porosity of aquifer material. Samples used for these estimates with modern water were all collected from wells screened in the PLB, SP, and DP aquifers. The length of each section was chosen to coincide with computation lines used by Clark and Appel (1985, table 8 and fig. 9). An average thickness from the top of the SP aquifer to the top of the QT aquifer was used as the height for the cross-sectional area for each of the sections. Average linear ground-water velocity and recharge estimates for two areas are summarized in table 24. Samples classified as modern were not available to calculate ground-water velocity for other parts of the valley.

The American Fork section for which recharge was estimated in table 24 coincides with computation lines 6 , 7, and 8 in table 8 and figure 9 of Clark and Appel (1985). Average linear velocities from five flowpaths in this area vary from 1.5 to $3.0 \mathrm{ft} / \mathrm{d}$ and corresponding recharge estimates range from 26,900 to 53,000 acre-ft/yr, with a median value of about 41,000 acre-ft/yr. Recharge estimates using apparent-age gradients are 40 to 78 percent lower than the 68,000 acre-ft/yr of recharge estimated by Clark and Appel (1985) for this section of the valley. The Battle Creek section coincides with computation lines 9 and 10 in table 8 and figure 9 of Clark and Appel (1985). Average linear velocities were estimated between sample sites 24 and 26 and from the mountain front (assuming this is where the recharge of modern water occurred) to sample sites 24 and 26. Average linear velocities in the Battle Creek area are from 1.5 to $1.8 \mathrm{ft} / \mathrm{d}$ with recharge for this section estimated to range from about 26,500 to 31,400 acre-ft/yr. Clark and Appel (1985) estimated 24,000 acre-ft/yr of recharge to this section of the basin-fill aquifers. Although these estimates incorporate significant generalizations regarding aquifer thickness and ground-water flowpaths, they indicate that the age data are in general agreement with previous concepts of ground-water flow in northern Utah Val-

Table 24. Estimates of volumetric recharge rate to sections of northern Utah Valley, Utah, based on tritium/helium-3 age data.

[Sample identifier: See figure 35 for the location of sites sampled as part of this study. A bbreviations: $n$, average effective porosity of aquifer material (including lower permeability layers); $Q$, recharge rate]

\begin{tabular}{|c|c|c|c|c|c|}
\hline \multicolumn{3}{|c|}{ American Fork section } & \multicolumn{3}{|c|}{ Battle Creek section } \\
\hline $\begin{array}{l}\text { Flowpath, from } \\
\text { sample identifier to } \\
\text { sample identifier }\end{array}$ & $\begin{array}{l}\text { Average linear } \\
\text { ground-water } \\
\text { flow velocity } \\
\text { (feet/day) }\end{array}$ & $\begin{array}{c}\text { Volumetric } \\
\text { rate of recharge } \\
\text { (acre-feet/year) } \\
\text { (rounded) }\end{array}$ & $\begin{array}{l}\text { Flowpath, from } \\
\text { sample identifier to } \\
\text { sample identifier }\end{array}$ & $\begin{array}{l}\text { Average linear } \\
\text { ground-water } \\
\text { flow velocity } \\
\text { (feet/day) }\end{array}$ & $\begin{array}{c}\text { Volumetric } \\
\text { rate of recharge } \\
\text { (acre-feet/year) } \\
\text { (rounded) }\end{array}$ \\
\hline 14 to 5 & 1.5 & 26,900 & 24 to 26 & 1.6 & 27,500 \\
\hline 14 to 16 & 2.4 & 41,400 & Mountain front to ${ }^{2} 26$ & 1.8 & 31,400 \\
\hline 14 to 17 & 1.8 & 31,400 & Mountain front to ${ }^{2} 24$ & 1.5 & 26,500 \\
\hline 16 to 21 & 3.0 & 53,000 & & & \\
\hline
\end{tabular}

${ }^{1}$ This is estimated to be the maximum thickness from the top of the SP aquifer to the top of the QT aquifer in the Provo River area.

${ }^{2}$ These estimates assume recharge occurs at the mountain front. Average linear flow velocity and thus recharge $(Q)$ would be higher if recharge occurred farther back in the mountains. 
ley. The volumetric recharge rates calculated from age data compare well with previous estimates of recharge along the western slope of the Wasatch Mountains south of American Fork and indicate that recharge to the principal aquifer may be lower than previously thought in the American Fork area. This example highlights the usefulness of environmental-tracer data for constraining recharge.

\section{Flowpath Characterization}

Ground-water flow within the basin-fill aquifer occurs along a downgradient path generally following the surficial topography. The primary mechanisms controlling flowpaths in northern Utah Valley include the aquifer properties (grain size, hydraulic conductivity) and the location of the recharge or subsurface inflow source (mountain block, mountain front, irrigation seepage). Aquifer properties in northern Utah Valley, on a basin scale, grade from materials with a high hydraulicconductivity value (more transmissive) such as cobble, gravel, and sand deposits near the mountain fronts, to materials with a low hydraulic-conductivity value (less transmissive) such as interbedded gravel, sand, silt, and clay deposits throughout the valley bottom. The interbedded deposits of the valley bottom form basin-extensive confined aquifers as discussed in the "Occurrence of Ground Water" section of this report.

In addition to aquifer properties, flowpaths also are controlled by the location of the predominant recharge sources. In northern Utah Valley the primary recharge sources include subsurface inflow at the mountain-block basin-fill interface (mountain-block inflow) and recharge occurring at the surface along the mountain front (mountain-front recharge). Mountain-block subsurface inflow occurs at depth and is distributed over a large area that expands across the subsurface interface between the mountain block and basin-fill deposits (fig. 46).

Water from four wells that are assumed to be completed exclusively in the QT aquifer on the east side of the valley was sampled as part of this study (samples 10,11, 18, and 28). Water from each of these wells has similar chemical properties (low dissolved-solids concentrations, mixed cation water types, high terrigenic helium values, and pre-modern apparent ages), yet distinctly different chemical signatures than the samples collected from the shallower SP, DP, and PLB aquifers (higher dissolved-solids concentrations, generally calcium-bicarbonate type waters, and modern or mixed apparent ages). Water within the QT aquifer is expected to travel over longer flowpaths and have older apparent ages relative to water within the shallower aquifers. Lower dissolved-solids concentrations with increasing depth are attributed to the mountain-block subsurface inflow to the QT aquifer. Mountain-block subsurface inflow travels through preferential pathways such as fractures, faults, and solution channels in much of the limestone mountain block, effectively reducing the reactive surface area between the ground water and the aquifer material. Hydraulic gradients near the end of the flowpath (in the valley lowlands) have an upward vertical component, so that ground water in the deeper basin-fill aquifers moves upward through overlying leaky confining units to subsequently shallower basin-fill aquifers. Flow through these units allows for the dissolution of constituents within the basin-fill deposits. The dissolved solids can then be transported to the shallower basin-fill aquifers and to springs near the valley bottom. Ground-water flow from different subsurface inflow and recharge source areas and the evolution of the major-ion chemistry along the Dry Creek, American Fork, and combined Orem-Provo area flowpaths are shown in figures 47, 48, and 49 , respectively.

Mountain-front recharge is localized and focused over areas where water from streams and creeks entering the valley infiltrates into the basin-fill aquifers. These recharge areas are further expanded by the distribution of streamflow within irrigation canals and subsequent seepage from the canals. Two main areas of northern Utah Valley include the Alpine/Highland area where Dry Creek and the American Fork River enter the valley and the Orem-Provo area where the Provo River enters the valley. In both areas, the potentiometric contours for the combined PLB and DP aquifer indicate flow moving away from the canyon mouths and toward Utah Lake (fig. 27).

Along the Dry Creek channel, inflow of Dry Creek and Fort Creek provide recharge to the northern part of the Highland Bench and contribute to the Dry Creek flowpaths. This path generally follows the Dry Creek channel and moves west-southwestward along the front of the Traverse Mountains. Recharge temperatures (fig. 42), apparent ages (fig. 45), and dissolved-solids concentrations generally follow expected trends of decreasing recharge temperature, increasing apparent age, and increasing dissolved-solids concentrations along the theoretical Dry Creek flowpath (fig. 47). Inflow from the American Fork River is the dominant force influencing recharge to the SP and DP aquifers to the south of the Dry Creek flowpath. The American Fork River discharges about three times the amount of water as Dry Creek, with much of it occurring as seepage to the basin-fill aquifers near the mouth of American Fork Canyon. Potentiometric contours in the combined PLB and DP aquifer (fig. 27) indicate ground-water flow radiating out from the mouth of American Fork Canyon and away from the stream channel farther into the valley. Apparent ages of water increase with distance from the mouth of American Fork Canyon (fig. 45). Dissolved-solids concentrations along the American Fork flowpath increase with distance from the mountain front and increase from the lower QT aquifer up to the surface (fig. 48). Mountain-front recharge from Grove Creek and Battle Creek and irrigation losses in the Battle Creek flowpath area provide some additional recharge to the SP and DP aquifers (fig. 46).

Seepage from the Provo River and its associated irrigation canal network dominates recharge to the SP and DP aquifers in the Orem-Provo area. Dissolved-solid concentrations in water from wells sampled throughout the Orem-Provo area varied little between wells and had concentrations similar to that of the Provo River. Water-quality samples were collected 


\section{EXPLANATION}

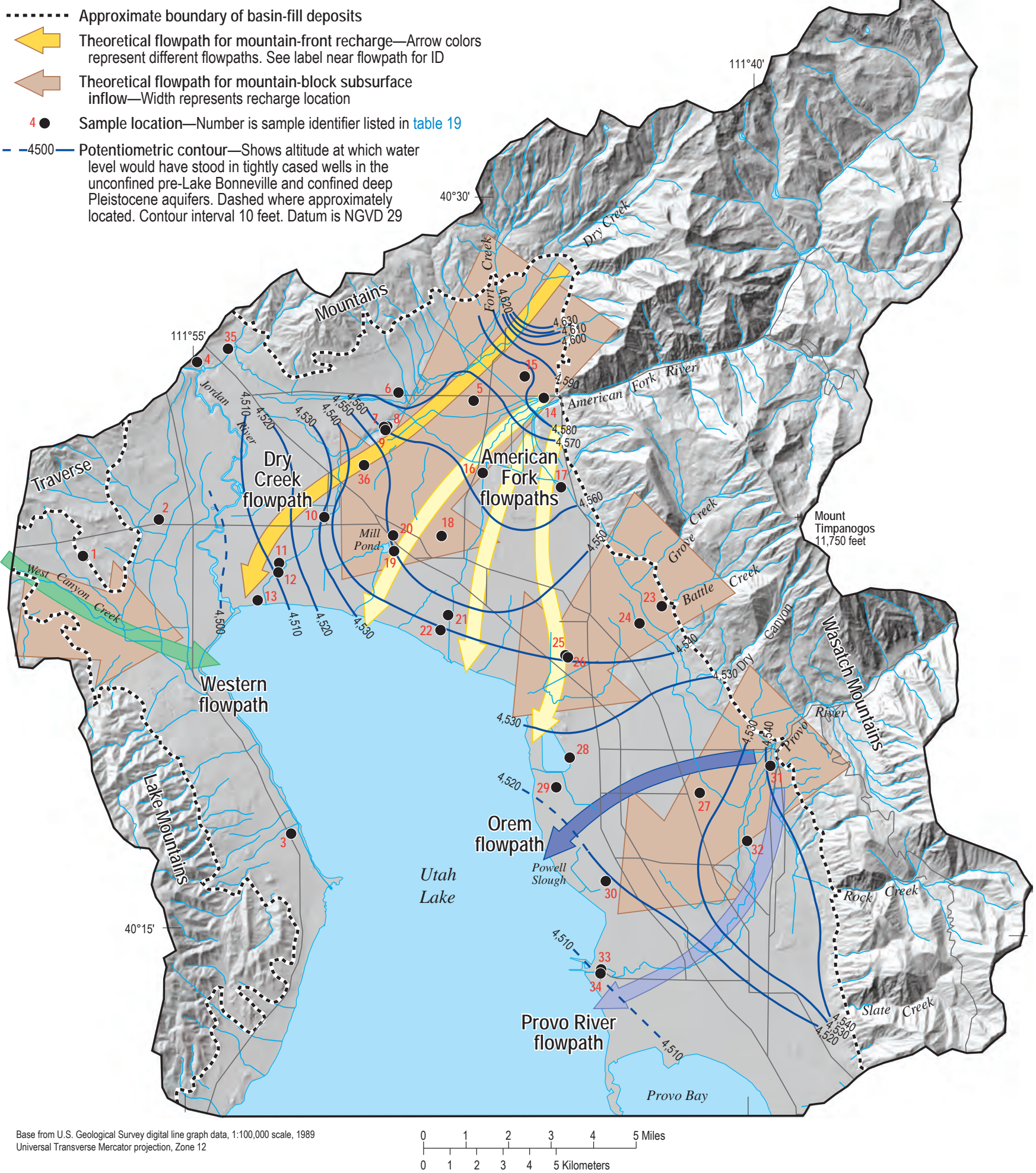

Figure 46. Generalized flowpaths originating from mountain-block subsurface inflow and recharge sources along the mountain front in northern Utah Valley, Utah. 


\section{EXPLANATION}

$\square 5 \Delta 11$

$\circ 6+12$

$07 \times 13$

- 8015

$\square 9 \quad \nabla 19$

$\Delta 10 \quad \bullet 20$

Number references sample identifier (Table 19)

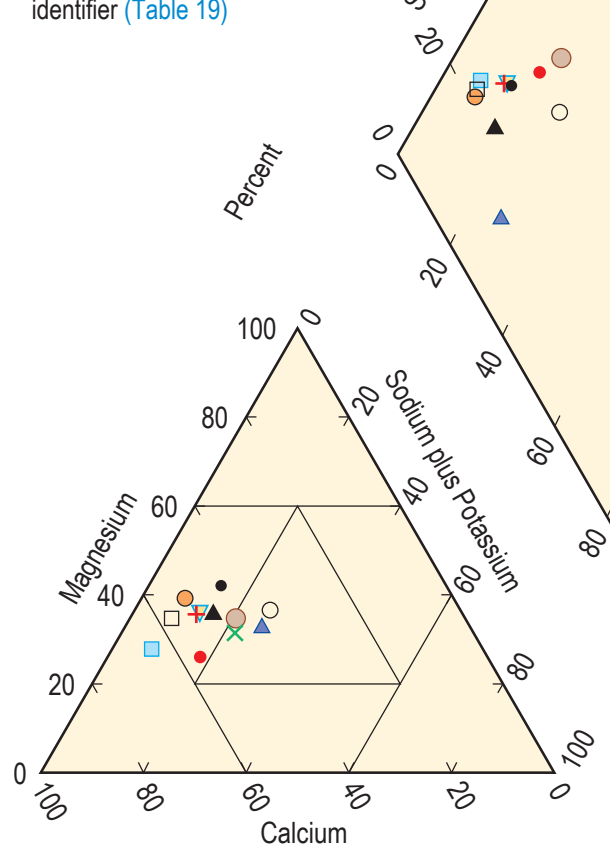

Percent

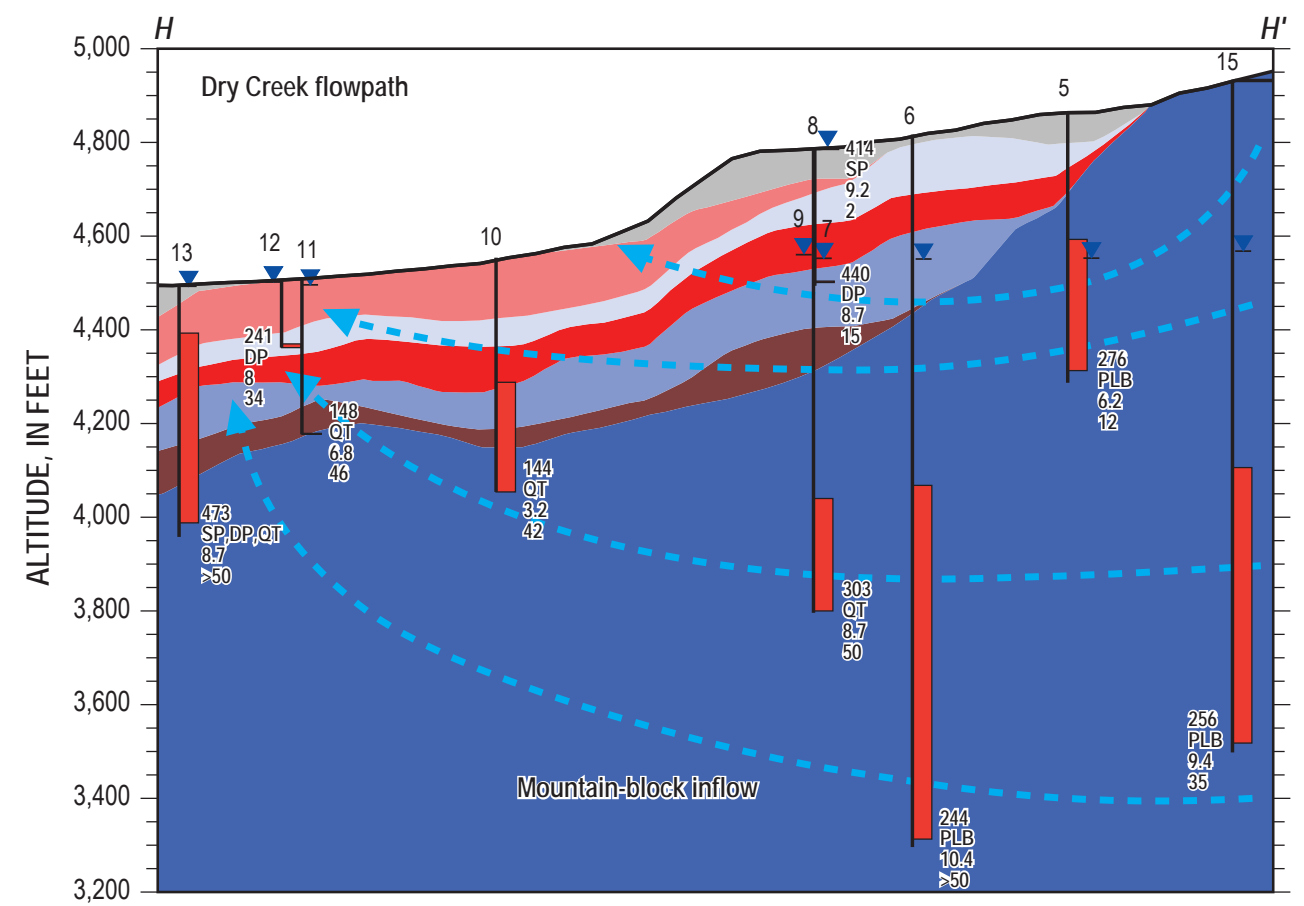

Figure 47. Location of sites sampled, direction of ground-water flow, and major-ion composition of water from wells along the Dry Creek flowpath, northern Utah Valley, Utah. 
EXPLANATION

$\Delta 14 \diamond 21$

$+16 \square 22$

$\times 17$

○ 18

$\nabla 19$

- 20

Number references sample identifier (Table 19)

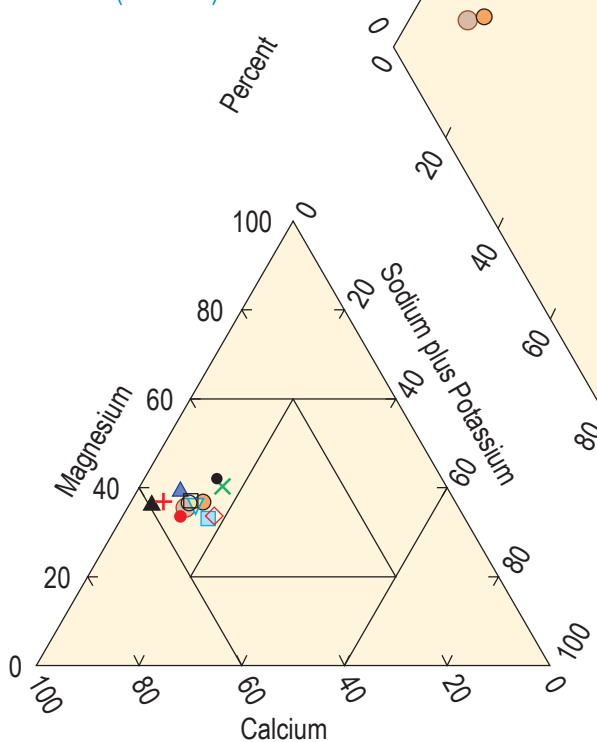

Percent

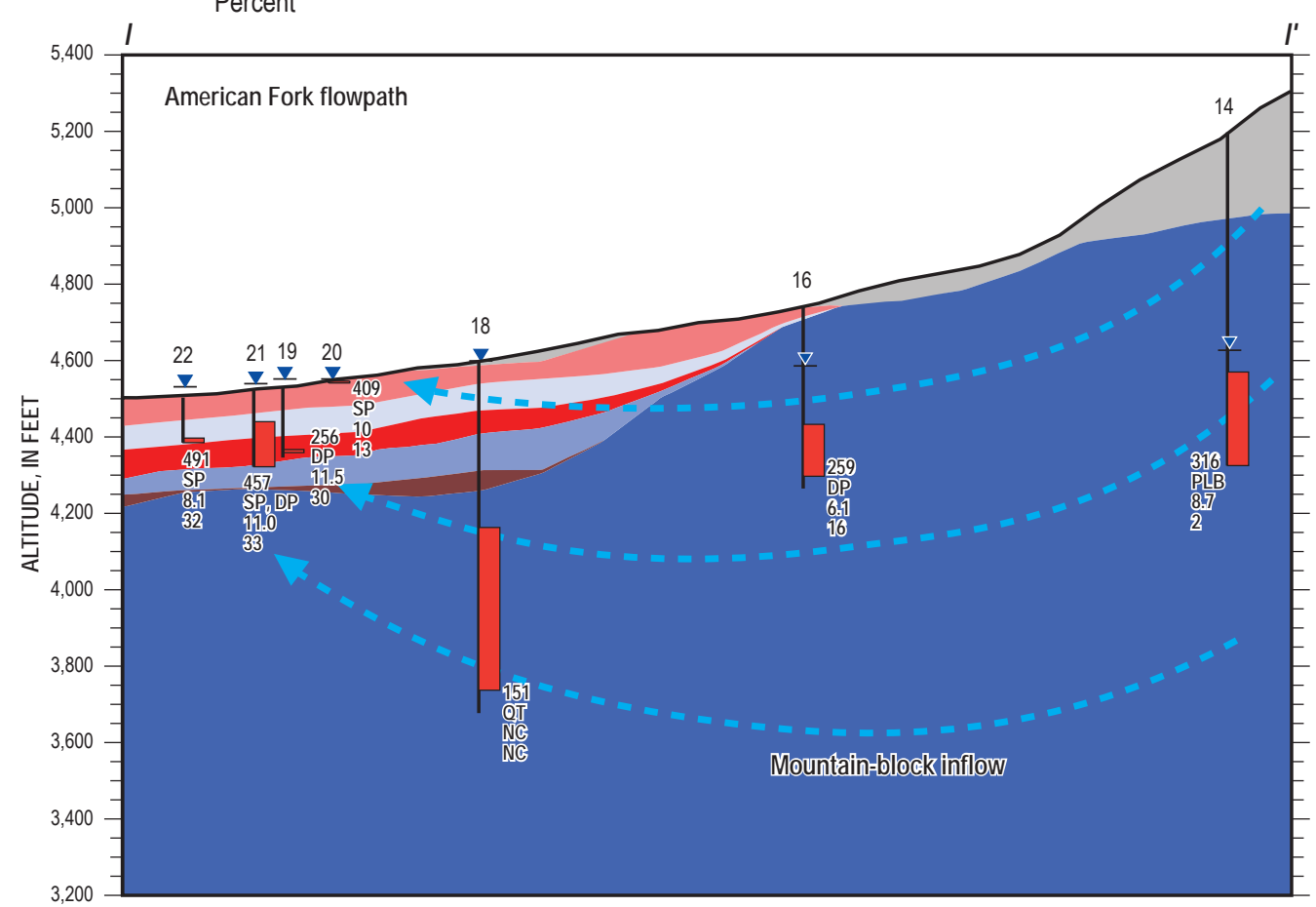

Figure 48. Location of sites sampled, direction of ground-water flow, and major-ion composition of water from wells along the American Fork flowpath, northern Utah Valley, Utah. 


\section{EXPLANATION \\ $\Delta 27$ \\ $\triangle 28$ \\ $+29$ \\ $\times 30$ \\ $\circ 31$ \\ $\nabla 32$ \\ - 33 \\ $\diamond 34$ \\ $\square$ Provo River}

Number references sample identifier (Table 19)

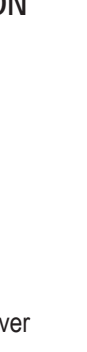

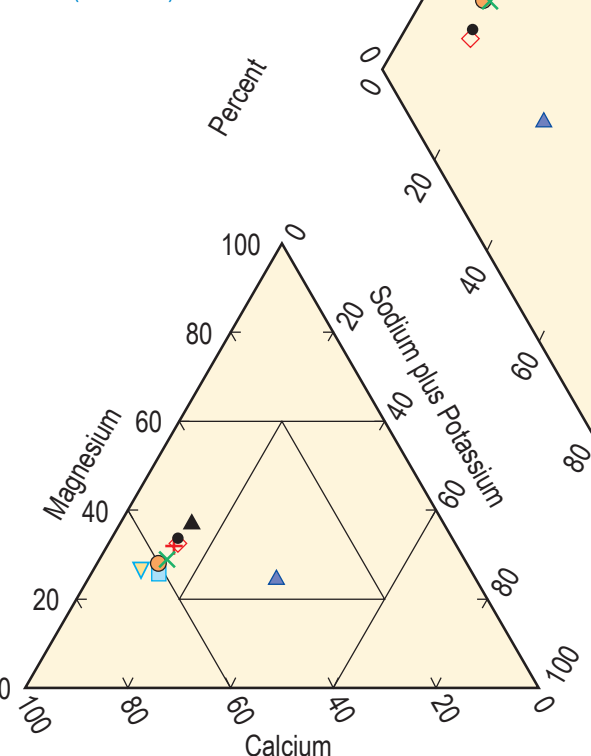

\section{EXPLANATION}

Hydrostratigraphy

Overburden

Confining unit 1

Shallow Pleistocene aquifer

Confining unit 2

Deep Pleistocene aquifer

Confining unit 3

Pre-Lake Bonneville and Quaternaryl Tertiary aquifers

28 Sample ID

z Water level

L Land surface

Screen/open interval

167 Dissolved solids, in milligrams per liter

QT Aquifer

10.7 Maximum recharge temperature, in degree Celsius-NC, not calculated

38 Apparent age, in years-NC, not calculated

Calcium

$$
\text { Percent }
$$

Percent

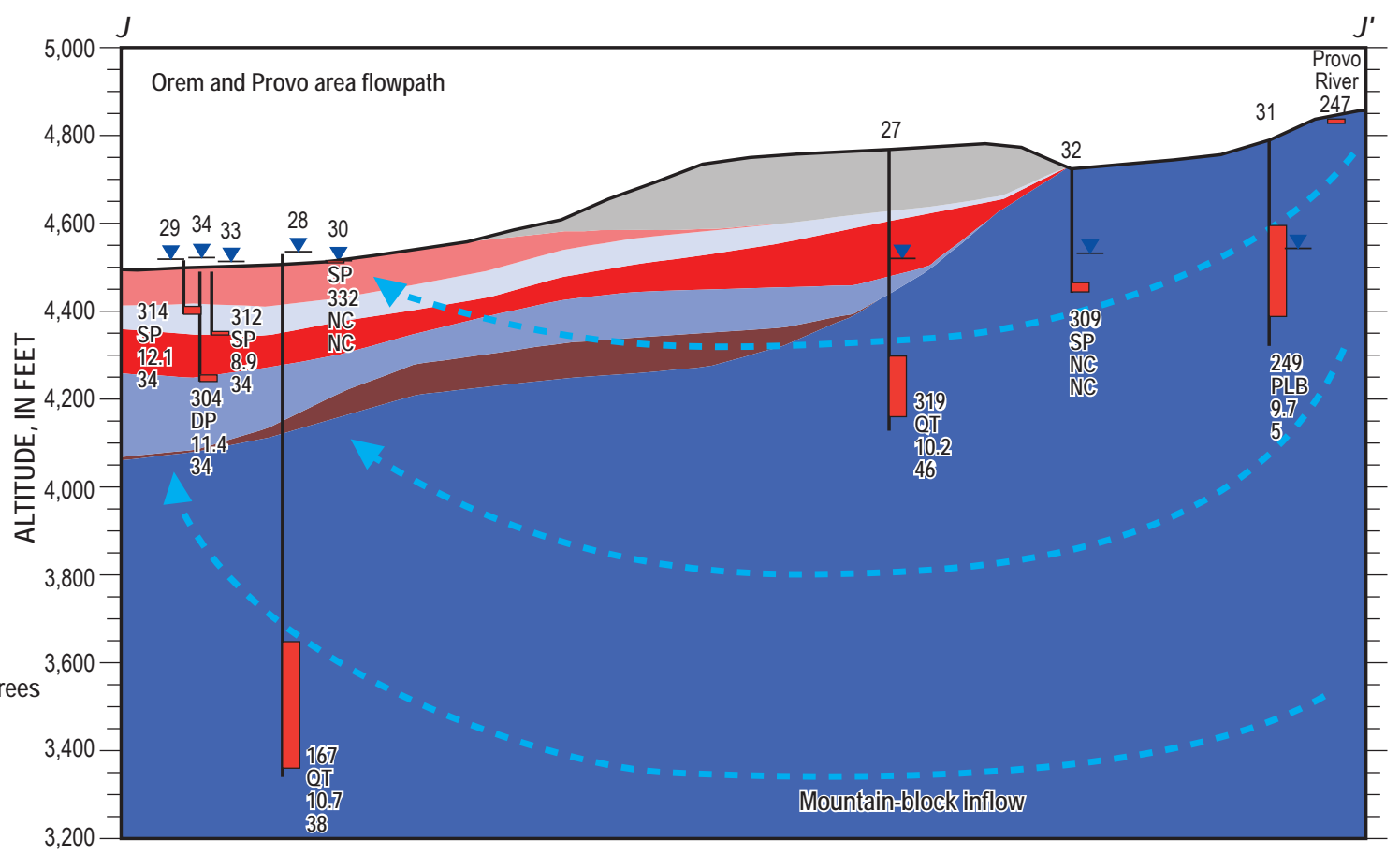

Figure 49. Location of sites sampled, direction of ground-water flow, and major-ion composition of water from wells along a flowpath in the Orem and Provo area, northern Utah Valley, Utah. 
from the Provo River at the mouth of Provo Canyon (USGS site number 401850111392201) in the spring of 2000 (snowmelt runoff) and summer of 2000 (base flow). Dissolved-solids concentrations in the stream samples (280 and $247 \mathrm{mg} / \mathrm{L}$ ) were similar to dissolved-solids concentrations in samples from wells in the SP and DP aquifers. In addition, they exhibit the same calcium-magnesium-bicarbonate water type as water samples collected from the SP and DP aquifers (fig. 49). Water from one well completed in the QT aquifer had a distinctively lower dissolved-solids concentration (sample 28, $167 \mathrm{mg} / \mathrm{L}$ ) than water samples from other wells in the Orem-Provo area. Apparent ages, mountain-block inflow fractions, and recharge temperatures for water from Orem-Provo area wells also show similar trends, implying that the predominant recharge or subsurface inflow source is likely the same for the SP and DP aquifers in the Orem-Provo area. Deep subsurface inflow from the mountain block is likely the source of the ground water with low dissolved-solids concentration in the QT aquifer along the Orem flowpath. The consistent chemical composition among samples collected from the SP and DP aquifers in the Orem-Provo area indicates that continuity of the confining unit (CF1) separating the SP and DP aquifers in the OremProvo area may not be as laterally continuous as it is in the northern part of the study area.

Some of the recharge to the basin-fill aquifers west of the Jordan River occurs as subsurface inflow from two separate sources, including a flowpath through the basin-fill deposits from Cedar Valley and a deeper flowpath through the fractured bedrock between the Lake Mountains and the Traverse Mountains (figs. 9 and 46). Samples 1, 2, and 3 have a distinctly different chemical composition as compared to samples collected east of the Jordan River (figs. 35 and 36). The different chemical composition, along with potentiometric contours depicting the eastward movement of ground water in the area west of the Jordan River (figs. 27 and 28), indicates a different recharge source. The flowpaths representing mountain-front recharge and mountain-block inflow likely originate in or cross through Cedar Valley before moving into northern Utah Valley and because of the long flowpath are likely pre-modern waters. This is supported by the pre-modern apparent ages determined for samples 1 and 3. For sample 2, a modern or mixed interpreted age (an apparent ${ }^{3} \mathrm{H} /{ }^{3} \mathrm{He}$ age of 18 years), a lower dissolved-solids concentration $(783 \mathrm{mg} / \mathrm{L})$, and an enriched $\delta^{18} \mathrm{O}$ value relative to $\delta \mathrm{D}$ value that is indicative of evaporation indicate another recharge or subsurface inflow source in the area of this well. A small ephemeral drainage basin originating in the Traverse Mountains enters the valley upgradient of the well, but a more likely source of recharge is the Utah Lake Distribution Canal that traverses the valley upgradient of the well. Seepage from the canal and associated irrigated fields is the likely source of the evaporated water.

Faulting west of the Jordan River and in Utah Lake (fig. 2) may provide an avenue for thermal water to enter the basinfill aquifers in the area. Ground water sampled from wells in the faulted area during previous studies had dissolved-solids concentrations ranging from 960 to $1,380 \mathrm{mg} / \mathrm{L}$ and tempera- tures ranging from 18.5 to $30.0^{\circ} \mathrm{C}$ (U.S. Geological Survey, 2006). Water from a spring in Utah Lake (C-5-1)36ddd-S1 associated with the Utah Lake fault system was sampled in 1992 and had a dissolved-solids concentration of $1,510 \mathrm{mg} / \mathrm{L}$ and a water temperature of $43^{\circ} \mathrm{C}$ (Robert Baskin, U.S. Geological Survey, oral commun., 2006). Ground water west of Utah Lake and along the Jordan River corridor may consist of a mixture of fault-controlled thermal waters and ground water from the basin-fill aquifers (figs. 27 and 28).

\section{Summary}

The ground-water resources of northern Utah Valley, Utah, were assessed during 2003-05 to describe and quantify components of the hydrologic system, determine a hydrologic budget for the basin-fill aquifer, and evaluate changes to the system relative to previous studies. Northern Utah Valley is a horst and graben structure with ground-water occurring in both the mountain-block uplands surrounding the valley and in the unconsolidated basin-fill sediments. The principal aquifer in northern Utah Valley occurs in the unconsolidated basin-fill deposits where a deeper unconfined aquifer occurs near the mountain fronts and laterally grades into multiple confined aquifers near the center of the valley.

A three-dimensional hydrostratigraphic framework was developed to represent the extent, both areally and at depth, of the aquifers and confining units comprising the principal basin-fill aquifer in northern Utah Valley. Individual framework units were constructed by using a computer program to interpolate a surface between the delineated points to represent the contact between hydrostratigraphic units. The hydrostratigraphic framework was developed to be used in the numerical ground-water flow model being developed concurrently (2007).

Precipitation throughout the surrounding mountains is the main source of water for the basin-fill aquifers. Recharge to the basin-fill aquifers occurs predominantly as either infiltration of streamflow at or near the interface of the mountain front and valley or as subsurface inflow from the adjacent mountains. Natural discharge from the basin-fill aquifers occurs in the valley lowlands as flow to waterways, drains, ditches, springs, and as diffuse seepage. Flowing and pumping wells also are a source of discharge.

Total recharge to the principal basin-fill aquifer was estimated to average $153,000(+/-31,500)$ acre-ft annually during 1975 to 2004 . Recharge from infiltration of streamflow averaged 68,500 (+/- 6,900) acre-ft/yr. Subsurface inflow from the adjacent mountains and Cedar Valley averaged 73,500 (+/$22,500)$ acre-ft/yr. Smaller recharge sources averaged 11,000 $(+/-2,100)$ acre-ft/yr.

Ground-water discharge from the basin-fill aquifers during 1975-2004 was estimated to average 166,700 (+/- 25,900) acre-ft/yr. Two primary sources of discharge include discharge to wells for consumptive use and discharge to waterways, 
drains, ditches, and springs. Discharge to wells, including pumping, flowing, and stock wells, was estimated to average $61,000(+/-10,000)$ acre-ft/yr. Discharge to waterways, drains, ditches, and springs was estimated to average 69,000 (+/6,900) acre-ft/yr.

The annual average hydrologic budget shows a deficit in recharge of about 14,000 acre-ft/yr. The difference in the hydrologic budget is likely a result of uncertainty and error in the individual budget estimates rather than an actual deficit.

Water levels in wells in northern Utah Valley declined from 1981 to 2004. Of 110 wells measured in both 1981-82 and 2004-05, the average decline in water levels was about $22 \mathrm{ft}$ for all aquifers combined. Water-level changes in the confined aquifers were less pronounced when compared to changes in the unconfined aquifer. Water-level declines are consistent with a severe regional drought beginning in 1999 and continuing through 2004.

Water samples were collected from 36 wells and springs throughout the study area along expected flowpaths. Water samples collected from 34 wells were analyzed for dissolved major ions, nutrients, and stable isotopes of hydrogen and oxygen. All 36 water samples were analyzed for dissolved-gas concentration including noble gases and tritium/helium-3.

Major-ion chemistry generally changes with distance from the recharge source and with depth. Dissolved-solid concentrations generally decrease with depth into the basinfill deposits. Samples collected west of the Jordan River had higher dissolved-solid concentrations ( 783 to $1,590 \mathrm{mg} / \mathrm{L}$ ) than samples collected east of the Jordan River (141 to 778 $\mathrm{mg} / \mathrm{L}$ ). Nitrate concentrations generally were the same as or less than natural background levels. Dissolved-gas recharge temperature data support the conceptual model of the basin-fill aquifers and highlight complexities of recharge patterns in different parts of the valley. Dissolved-gas data indicate that the highest elevation recharge sources for the basin-fill aquifers are subsurface inflow derived from recharge in the adjacent mountain block between the mouths of American Fork and Provo Canyons. Apparent ground-water ages in the basin-fill aquifer, as calculated using tritium/helium-3 data, range from 2 to more than 50 years. The youngest waters in the valley occur near the mountain fronts with apparent ages generally increasing in age near the valley lowlands and discharge area around Utah Lake.

Flowpaths are controlled by aquifer properties and the location of the predominant recharge sources, including subsurface inflow and recharge along the mountain front. Subsurface inflow is distributed over a large area across the interface of the subsurface mountain block and basin-fill deposits. Subsurface inflow occurs at a depth, below where mountainfront recharge occurs. Recharge along the mountain front is often localized and focused over areas where streams and creeks enter the valley with recharge enhanced by the associated irrigation canals.

\section{References Cited}

Aeschbach-Hertig, W., Peeters, F., Beyerle, U., and Kipfer, R., 1999, Interpretation of dissolved atmospheric noble gases in natural waters: Water Resources Research, v. 35, p. 2779-2792.

Aeschbach-Hertig, W., Peeters, F., Beyerle, U., and Kipfer, R., 2000, Paleotemperature reconstruction from noble gases in ground water taking into account equilibrium with trapped air: Nature, v. 405, p. 1044.

American Society of Civil Engineers, 1989, Water use by naturally occurring vegetation including an annotated bibliography: New York, 245 p.

Anderson, P.B., Susong, D.D., Wold, S.R., Heilweil, V.M., and Baskin, R.L., 1994, Hydrogeology of recharge areas and water quality of the principal aquifers along the Wasatch Front and adjacent areas, Utah: U.S. Geological Survey Water-Resources Investigations Report 93-4221, 74 p.

Anderson, T.W., Freethey, G.W., and Tucci, P., 1992, Geohydrology and water resources of alluvial basins in southcentral Arizona and parts of adjacent states: U.S. Geological Survey Professional Paper 1406B, 67 p.

Ballentine, C.J., and Hall, C.M., 1999, Determining paleotemperature and other variables by using an error-weighted, nonlinear inversion of noble gas concentrations in water: Geochimica et Cosmochimica Acta, v. 63, p. 2315-2336.

Baskin, R.L., Spangler, L.E., and Holmes, W.F., 1994, Physical characteristics and quality of water from selected springs and wells in the Lincoln Point-Bird Island area, Utah Lake, Utah: U.S. Geological Survey Water-Resources Investigations Report 93-4219, 54 p.

Beik, R.F., 2003, Geologic map of the Jordan Narrows quadrangle, Salt Lake and Utah Counties, Utah: Utah Geological Survey Open-File Report 415, 21 p.

Bissell, H.J., 1963, Lake Bonneville: Geology of southern Utah Valley, Utah: U.S. Geological Survey Professional Paper 257-B, 29 p.

Blackett, R.E., and Wakefield, S., 2004, Geothermal resources of Utah-2003: A digital atlas of Utah's geothermal resources: Utah Geological Survey Open-File Report 431, $49 \mathrm{p}$.

Branson, F.A., Miller, R.F., and McQueen, I.S., 1970, Plant communities and associated soil and water factors on shalederived soils in northeastern Montana: Ecology, v. 23, no. 2, p. 240-245. 
Brooks, L.E., and Stolp, B.J., 1995, Hydrology and simulation of ground-water flow in southern Utah and Goshen Valleys, Utah: Utah Department of Natural Resources Technical Publication No. 111, 96 p.

Brooks, L.E., Stolp, B.J., and Spangler, L.E., 2003, Hydrology and simulation of ground-water flow in Kamas Valley, Summit County, Utah: Utah Department of Natural Resources Technical Publication No. 117, 74 p.

Brown, H.E., and Thompson J.R., 1965, Summer water use by aspen, spruce, and grassland in western Colorado: Journal of Forestry, v. 63, no. 10, p. 756-760.

Bureau of Reclamation, 1968, Use of water on Federal irrigation projects, 1966 and 1967 detailed reports, Volume 1, Eden Project, Wyoming; Strawberry Valley Project, Utah: Salt Lake City, Utah.

Bureau of Reclamation, 1969, Use of water on Federal irrigation projects, 1968 detailed report, Volume II, Strawberry Valley Project, Utah, West Mountain study area: Salt Lake City, Utah.

Burden, C.B., and others, 2005, Ground-water conditions in Utah, spring of 2005: Utah Department of Natural Resources Cooperative Investigations Report No. 46, 138 p.

Clark, D.W., 1984, The ground-water system and simulated effects of ground-water withdrawals in northern Utah Valley, Utah: U.S. Geological Survey Water-Resources Investigations Report 85-4007, 56 p.

Clark, D.W., and Appel, C.L., 1985, Ground-water resources of northern Utah Valley, Utah: Utah Department of Natural Resources Technical Publication No. 80, 115 p.

Cook, P.G., Solomon, D.K., Sanford, W.E., Busenberg, E., Plummer, L.N., and Poreda, R.J., 1996, Inferring shallow ground-water flow in saprolite and fractured rock using environmental tracers: Water Resources Research, v. 32, p. 1501-1509.

Cordova, R.M., and Subitzky, Seymour, 1965, Ground water in northern Utah Valley, Utah-A progress report for the period 1948-63: Utah Department of Natural Resources Technical Publication No. 11, 41 p.

Craig, H., 1961, Isotopic variations in meteoric waters: Science, v. 133. p. 1702-1703.

Daly, C., Neilson, R.P., and Phillips, D.L., 1994, A statisticaltopographic model for mapping climatological precipitation over mountainous terrain: Journal of Applied Meteorology, v. 33, p. 140-158.

Dominico, P.A., and Schwartz, F.W., 1998, Physical and chemical hydrogeology: John Wiley and Sons, New York, $506 \mathrm{p}$.
Feltis, R.D., 1967, Ground-water conditions in Cedar Valley, Utah County, Utah: Utah Department of Natural Resources Technical Publication No. 16, 34 p.

Fenneman, N.M., 1931, Physiography of the western United States: New York, McGraw-Hill, 534 p.

Flint, A.L., Flint, L.E., Hevesi, J.A., and Blainey, J.B., 2004, Fundamental concepts of recharge in the desert Southwest: A regional modeling perspective, in Hogan, J.F., Phillips, F.M., and Scanlon, B.R., eds., Groundwater recharge in a desert environment of the southwestern United States: Washington D.C., American Geophysical Union, p. 159-184.

Fuhriman, D.K., Merritt, L.B., Miller, W.A., and Stock, H.S., 1981, Hydrology and water quality of Utah Lake: Great Basin Naturalist Memoirs Number 5, Utah Lake Monograph: Provo, Utah, Brigham Young University, 169 p.

Hecker, S., 1993, Quaternary tectonics of Utah: Utah Geological Survey Bulletin 127, 157 p.

Hely, A.J., Mower, R.W., and Harr, C.A., 1971, Water resources of Salt Lake County, Utah: Utah Department of Natural Resources Technical Publication No. 31, 224 p.

Hem, J.D., 1992, Study and interpretation of the chemical characteristics of natural water: U.S. Geological Survey Water-Supply Paper 2254, 263 p.

Hill, B.R., 1990, Ground water discharge to a headwater valley, northwestern Nevada, USA: Journal of Hydrology, v. 113 , p. 265-283.

Hintze, L.F., Willis, G.C., Laes, D.Y.M., Sprinkel, D.A., and Brown, K.D., 2000, Digital geologic map of Utah: Utah Geological Survey, map 179DM.

Holocher, J., Matta, V., Aeschbach-Hertig, W., Beyerle, U., Hofer, M., Peeters, F., and Kipfer, R., 2001, Noble gas and major element constraints on the water dynamics in an alpine floodplain: Ground Water, v. 39, p. 841-852.

Huber, A.L., Haws, F.W., Hughes, T.C., Bagley, J.M., Hubbard, K.G., and Richardson, E.A., 1982, Consumptive use and water requirements for Utah: Utah Department of Natural Resources Technical Publication No. 75, 92 p.

Hunt, C.B., Varnes, H.D., and Thomas, H.E., 1953, Lake Bonneville: Geology of northern Utah Valley, Utah: U.S. Geological Survey Professional Paper 257-A, 99 p.

International Atomic Energy Agency, 2007, Isotope Hydrology Section database, accessed February 2007, at: http:// www-naweb.iaea.org/napc/ih/GNIP/IHS_GNIP.html. 
Jordan Valley Water Conservancy District, 2005, Water Conservancy Annual Report for 2005, accessed June 2006, at: http://www.jvwcd.org/Display. aspx? fid $=394 \&$ fname $=C C R+2005$. $p d f$.

Kaufmann, M.R., 1984, A canopy model (RM-CWU) for determining transpiration of subalpine forests-II. Consumptive water use in two watersheds: Canadian Journal of Forest Research, v. 14, p. 227-232.

Kipfer, R., Aeschbach-Hertig, W., Peeters, F., and Stute, M., 2002, Noble gases in lakes and ground waters, in Porcelli, D., and others, eds., Noble gases in geochemistry and cosmochemistry, Reviews in Mineralogy and Geochemistry, v. 47 , p. $615-700$.

Machette, M.N., 1992, Surficial geologic map of the Wasatch fault zone, eastern part of Utah Valley, Utah County and parts of Salt Lake and Juab Counties, Utah: U.S. Geological Survey Miscellaneous Investigations Series Map I-2095, scale 1:50,000.

Manning, A.H., 2002, Using noble gas tracers to investigate mountain-block recharge to an intermountain basin: Salt Lake City, University of Utah, Department of Geology and Geophysics, Ph.D. dissertation, 187 p.

Manning, A.H., and Solomon, D.K., 2003, Using noble gases to investigate mountain-front recharge: Journal of Hydrology, v. 275, p. 194-207.

Maxey, G.B., and Eakin, T.E., 1950, Ground water in White River Valley, White Pine, Nye and Lincoln Counties, Nevada: Nevada State Engineer, Water Resources Bulletin, no. 8,59 p.

Mayo, A.L., Herron, D., Nelson, S.T., Tingey, D., and Tranel, M., 2000, Geology and hydrology of Timpanogos Cave National Monument, in Sprinkel, D.A., Chidsey, T.C., and Anderson, P.B., eds., Geology of Utah's parks and monuments: Utah Geological Association Publication 28, p. 263-276.

Mower, R.W., 1970, Ground-water inflow toward Jordan Valley from Utah Valley through valley fill near the Jordan Narrows, Utah: U.S. Geological Survey Professional Paper 700-B, 4 p.

National Oceanic and Atmospheric Administration, 2006, data available on the Web, accessed April 3, 2006, at: http:// www.ncdc.noaa.gov/oa/climate/stationlocator.html

Plummer, L.N., Rupert, M.G., Busenberg, E., and Schlosser, P., 2000, Age of irrigation water in ground water from the eastern Snake River Plain aquifer, south-central Idaho: Ground Water, v. 38, p. 264-284.

Richardson, G.B., 1906, Underground water in the valleys of Utah Lake and Jordan River, Utah: U.S. Geological Survey Water-Supply and Irrigation Paper 157, 81 p.
Rockware ${ }^{\circledR}, 2004$, Rockworks 2004 user documentation, accessed January 2007, at: http://www.rockware.com/product/documentation.php?id=165.

Seaber, P.R., Kapinos, F.P., and Knapp, G.L., 1987, Hydrologic unit maps: U.S. Geological Survey Water-Supply Paper 2294, 14 p.

Sheldon, A., 2002, Diffusion of radiogenic helium in shallow ground water-Implications for crustal degassing: Salt Lake City, University of Utah, Ph.D. dissertation, 185 p.

Solomon, D.K., and Cook, P.G., 2000, ${ }^{3} \mathrm{H}$ and ${ }^{3} \mathrm{He}$, in Cook, P.G., and Herczeg, A.L., eds., Environmental tracers in subsurface hydrology: Boston, Kluwer Academic Publishers, p. 397-424.

Stute, M., and Schlosser, P., 2001, Atmospheric noble gases, in Cook, P.G., and Herczeg, A.L., eds., Environmental tracers in subsurface hydrology: Boston, Kluwer Academic Publishers, p. 349-377.

Susong, D.D., 1995, Water budget and simulation of onedimensional unsaturated flow in a flood- and sprinkler-irrigated field near Milford, Utah: Utah Department of Natural Resources Technical Publication No. 109, 32 p.

Thiros, S.A., and Manning, A.H., 2004, Quality and sources of ground water used for public supply in Salt Lake Valley, Salt Lake County, Utah, 2001: U.S. Geological Survey Water-Resources Investigations Report 03-4325, 95 p.

Tomlinson, S.A., 1996a, Evaluating evapotranspiration for six sites in Benton, Spokane, and Yakima Counties, Washington, May 1990 to September 1992: U.S. Geological Survey Water-Resources Investigations Report 96-4002, 84 p.

Tomlinson, S.A., 1996b, Comparison of Bowen-ratio, EddyCorrelation, and weighing-lysimeter evapotranspiration for two sparse-canopy sites in eastern Washington: U.S. Geological Survey Water-Resources Investigations Report 96-4081, 69 p.

U.S. Geological Survey, 2006, National Water Information System (NWISWeb) data available on the World Wide Web, accessed January 2006, at: http://waterdata.usgs.gov/nwis/.

Utah Department of Natural Resources, 2004, Downloadable GIS land use data: accessed April 2006, at: http://gis.utah. gov/vector.

Utah Division of Water Rights, 2006, Water distribution/ regulation-distribution system list: accessed June 2005, at: http://www.waterrights.utah.gov/cgi-bin/ dvrtview.exe?Modinfo=StationView\&STATION_ $I D=2335 \& R E C O R D \_Y E A R=2008$. 
Utah State University, 1994, Consumptive use of irrigated crops in Utah: Utah Agricultural Experiment Station Research Report 145, Utah State University, Logan, Utah, $361 \mathrm{p}$.

Utah Valley Economic Development Association, 2002, Population history: accessed May 2007, at: http://www.co.utah. ut.us/Dept/.

Wight, J.R., Hanson, C.L., and Cooley, K.R., 1986, Modeling evapotranspiration from sagebrush-grass rangeland: Journal of Range Management, v. 39, no. 1, p. 81-85.

Zoback, M.L., 1983, Structure and Cenozoic tectonism along the Wasatch fault zone, Utah: Geological Society of America Memoir 157, 27 p. 
Hydrology of Northern Utah Valley, Utah County, Utah, 1975-2005 
Appendix A. 


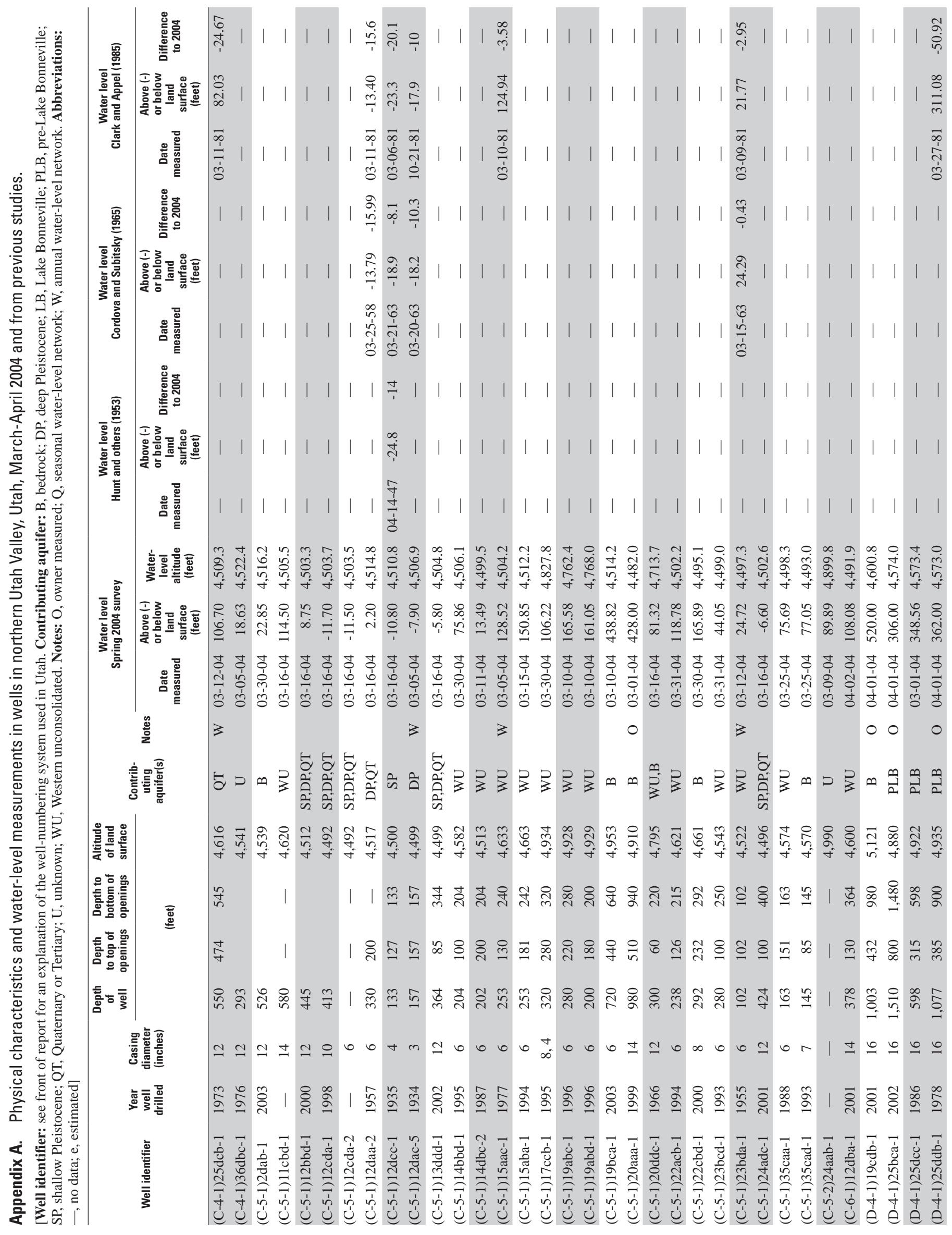




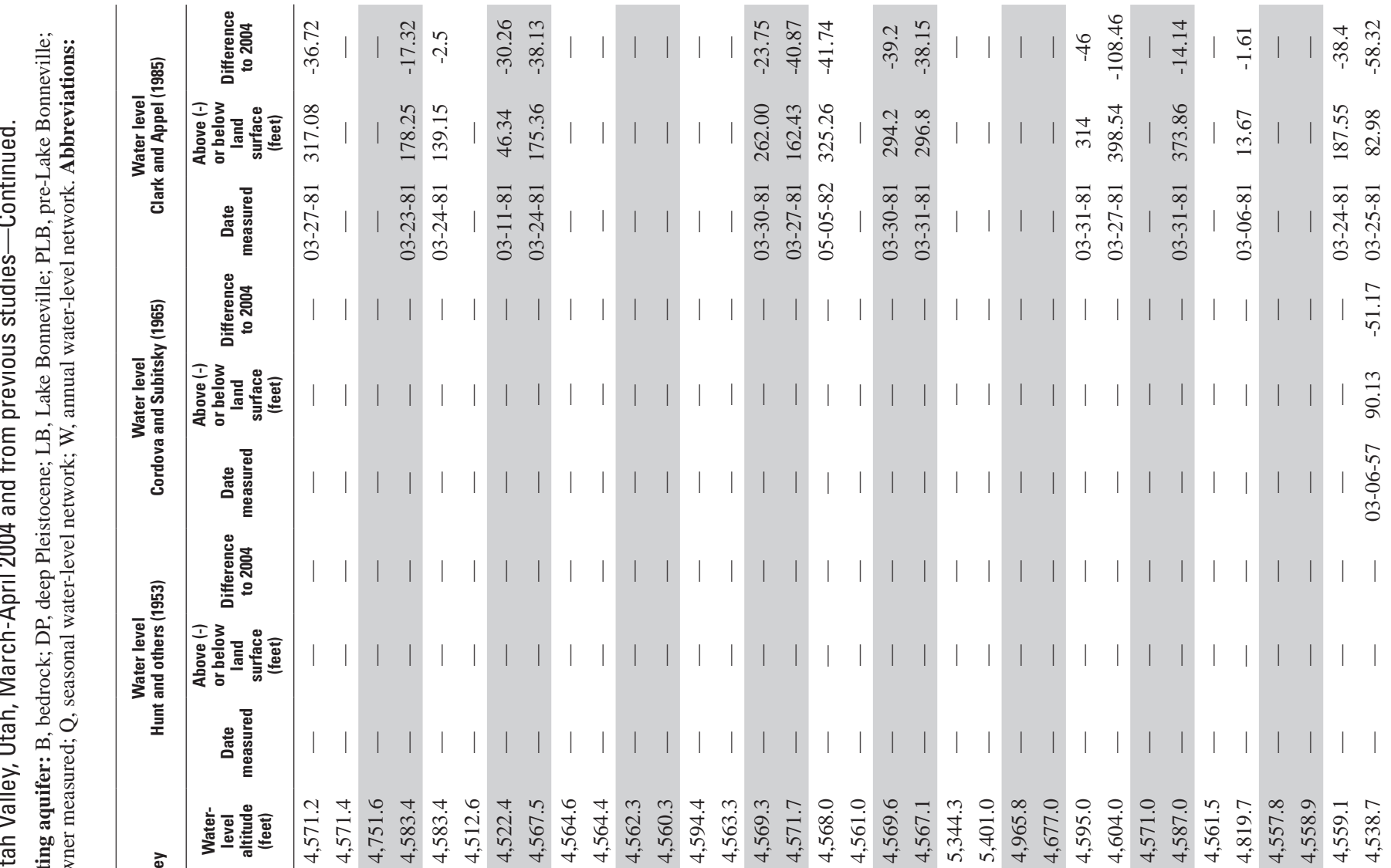

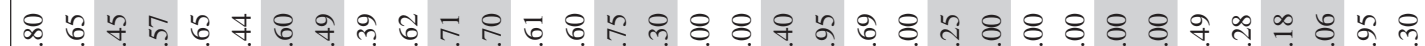
ભ

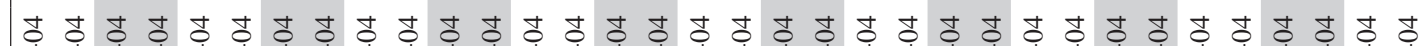

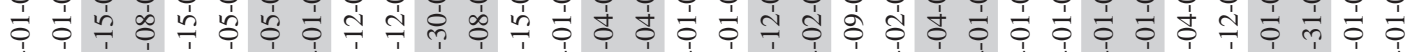

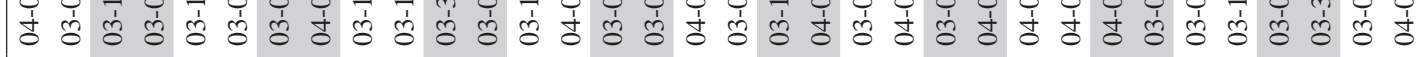
$\frac{2}{2}$

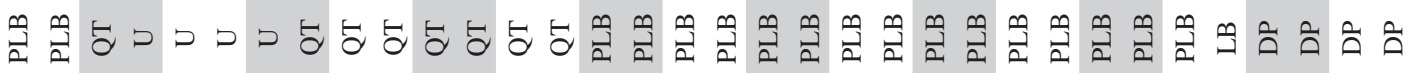

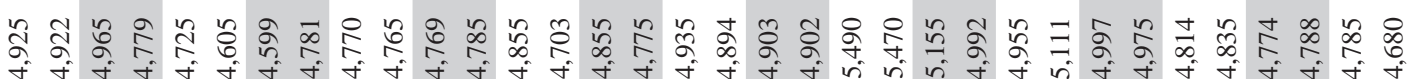

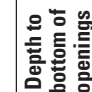

言咅高

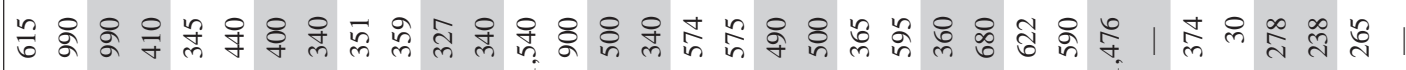

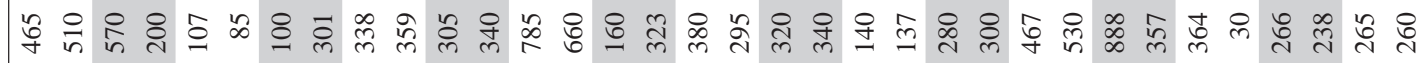
言部产

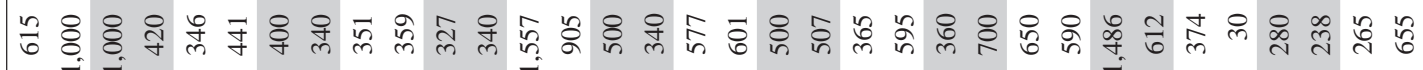

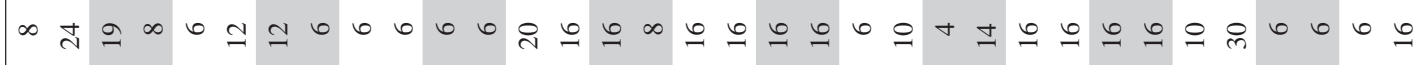




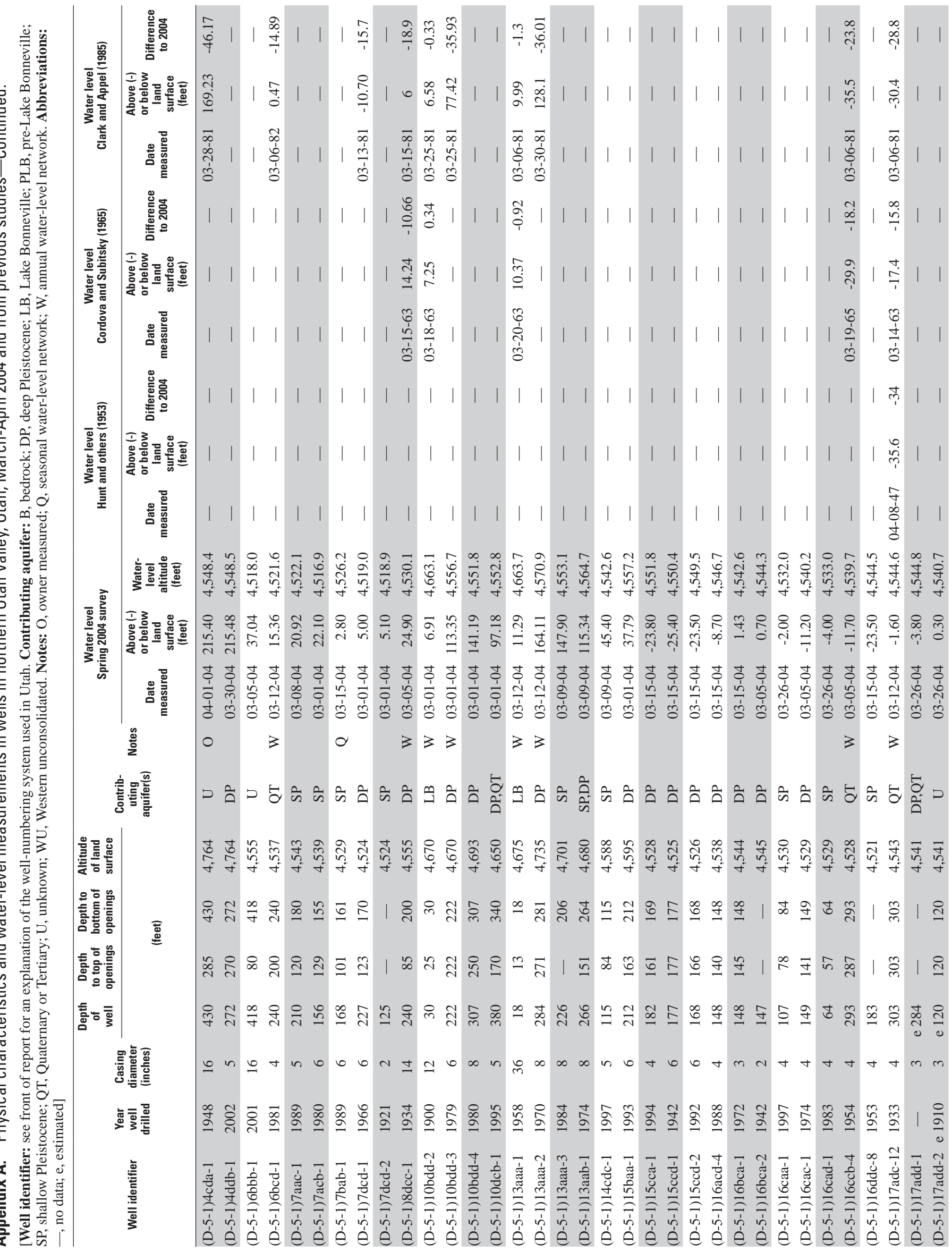




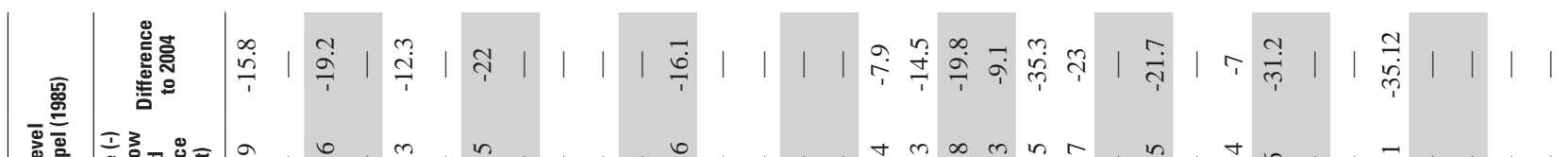

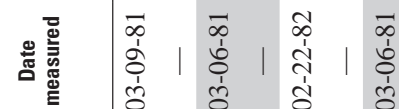

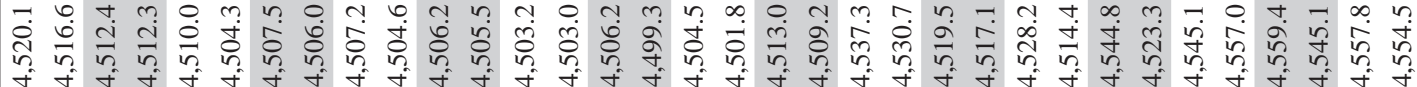

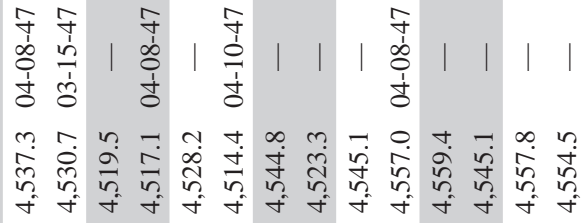

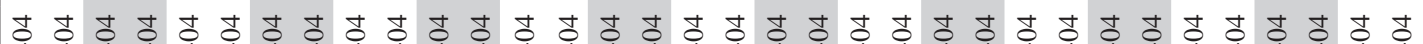

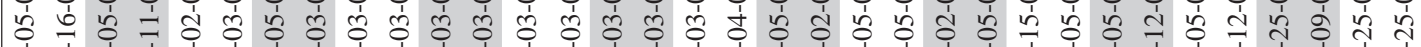

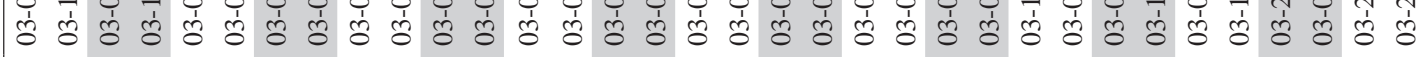

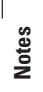

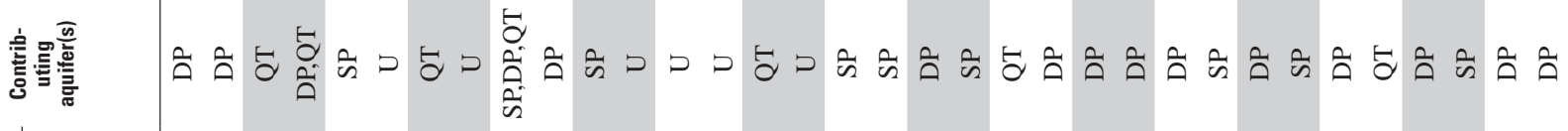

这喓

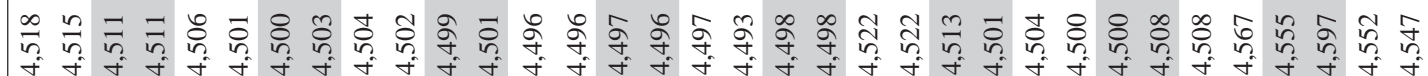

产高兽言

言高言衰

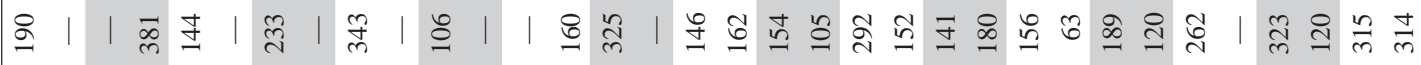

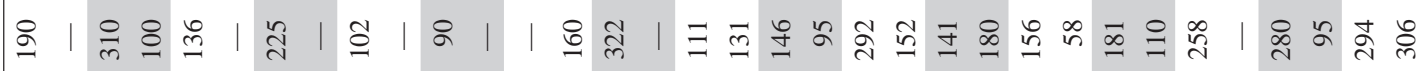
言喨

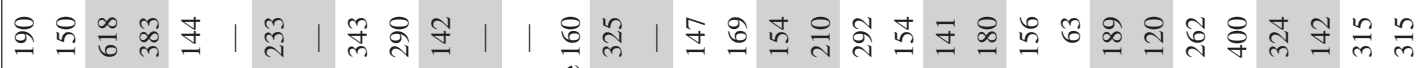




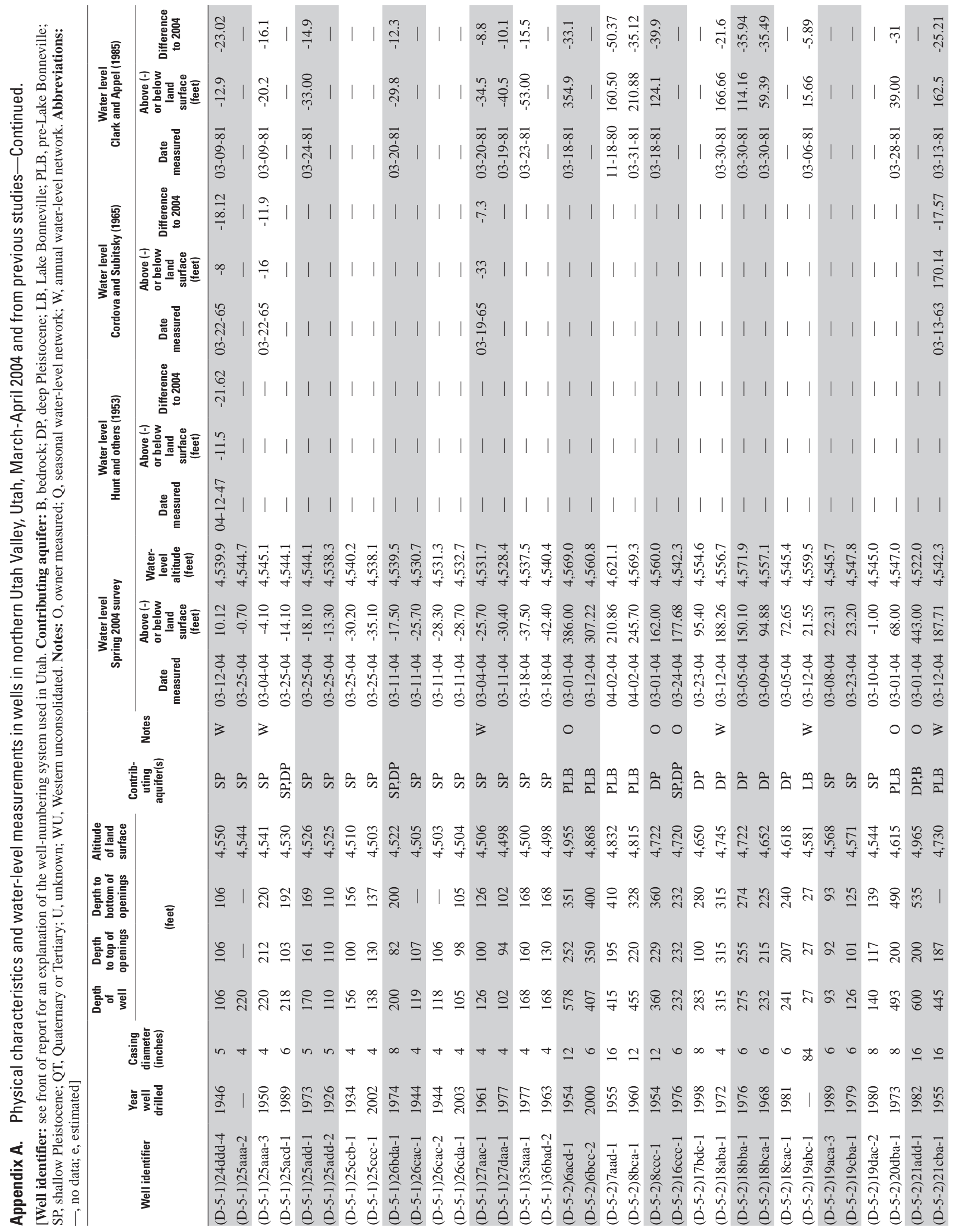




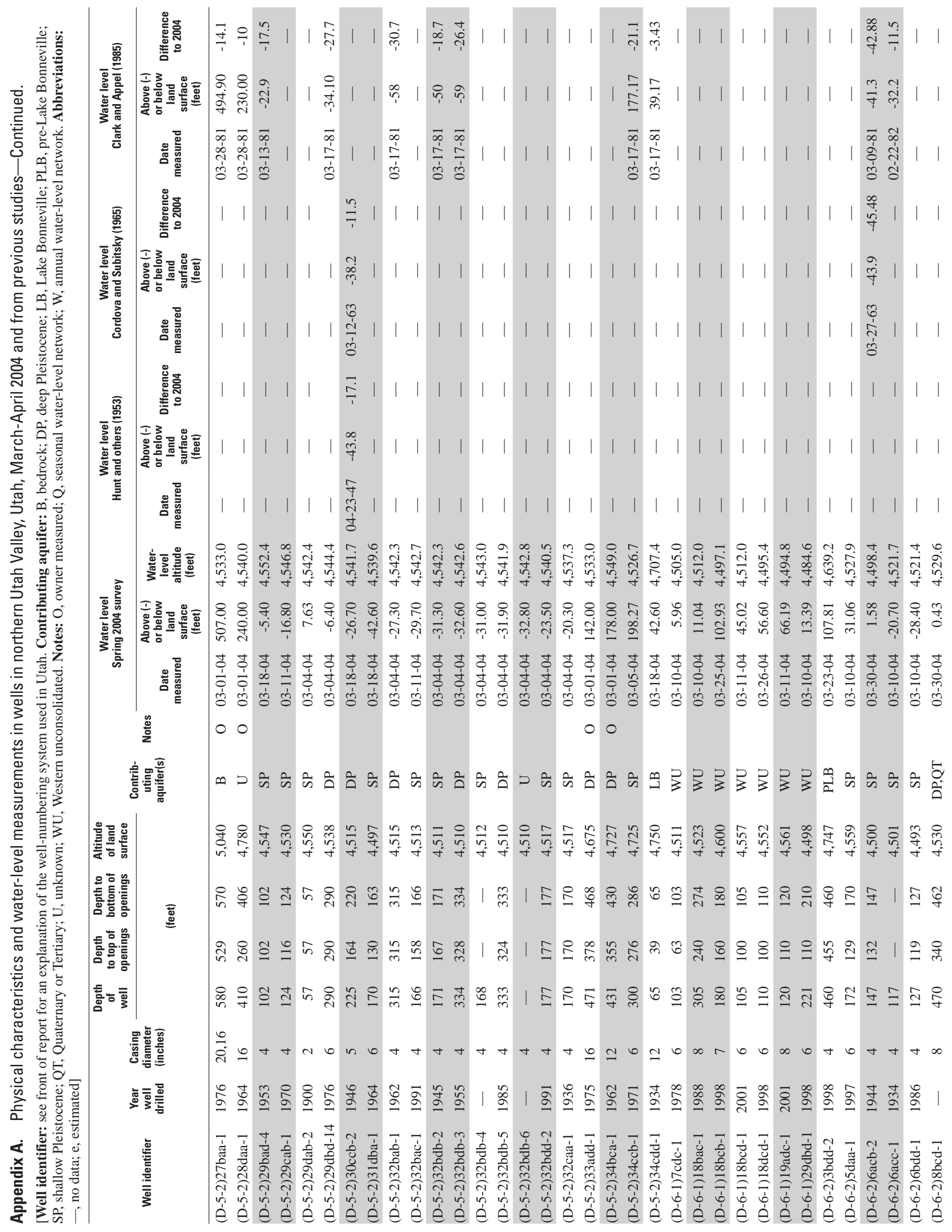




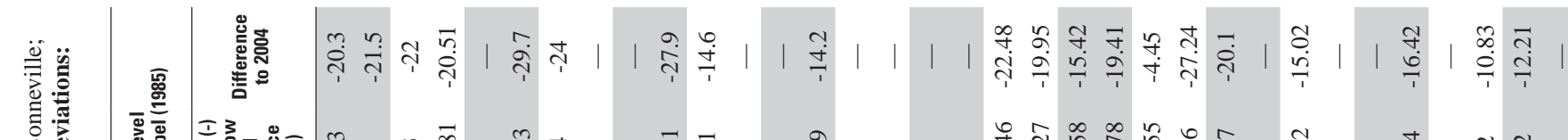

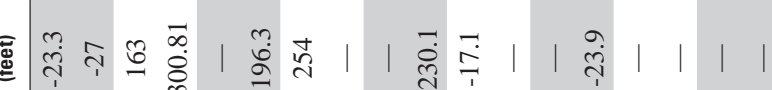

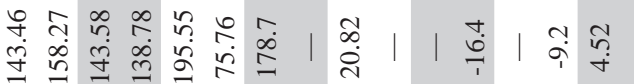
ำ

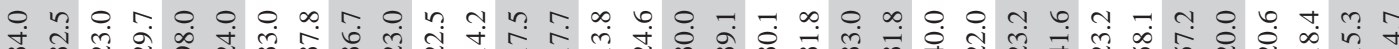

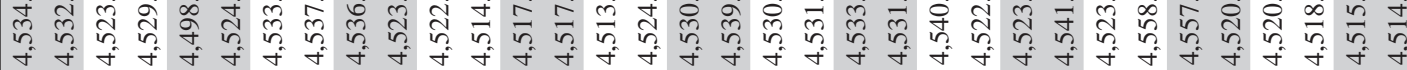
8 ก \&

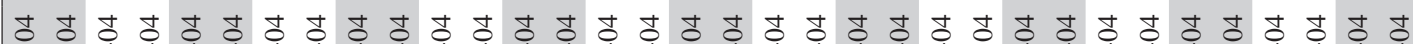

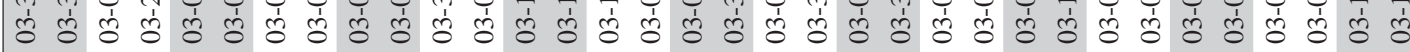

\section{$\circ$}

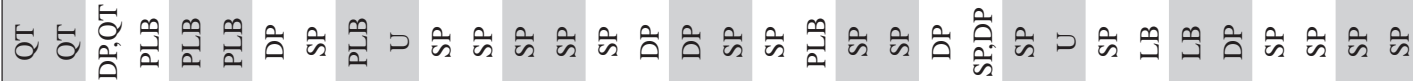

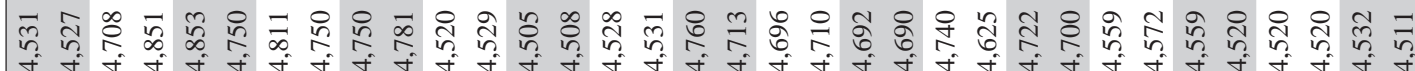

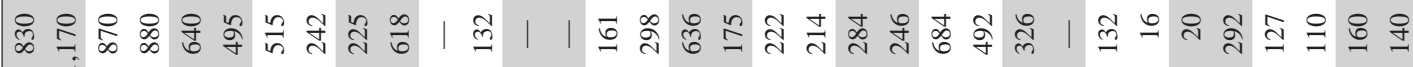

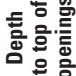

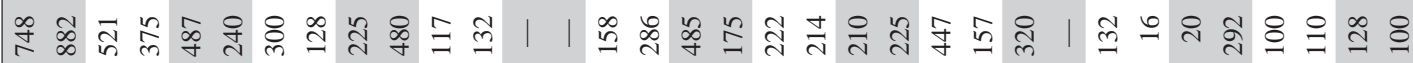
ळ: \&

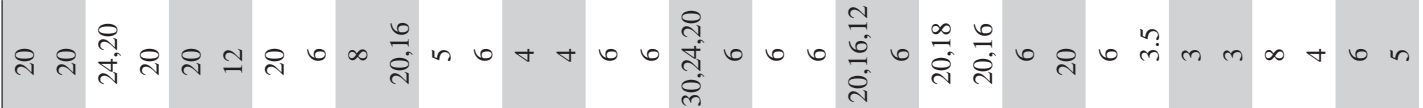

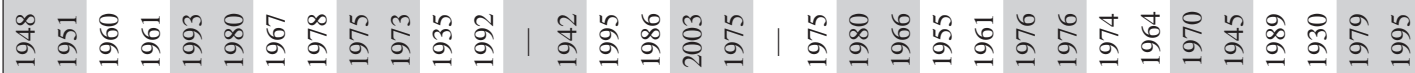

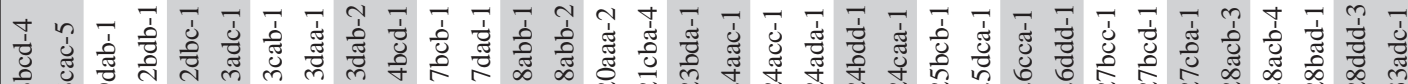
穴

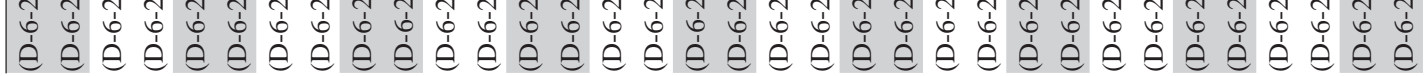




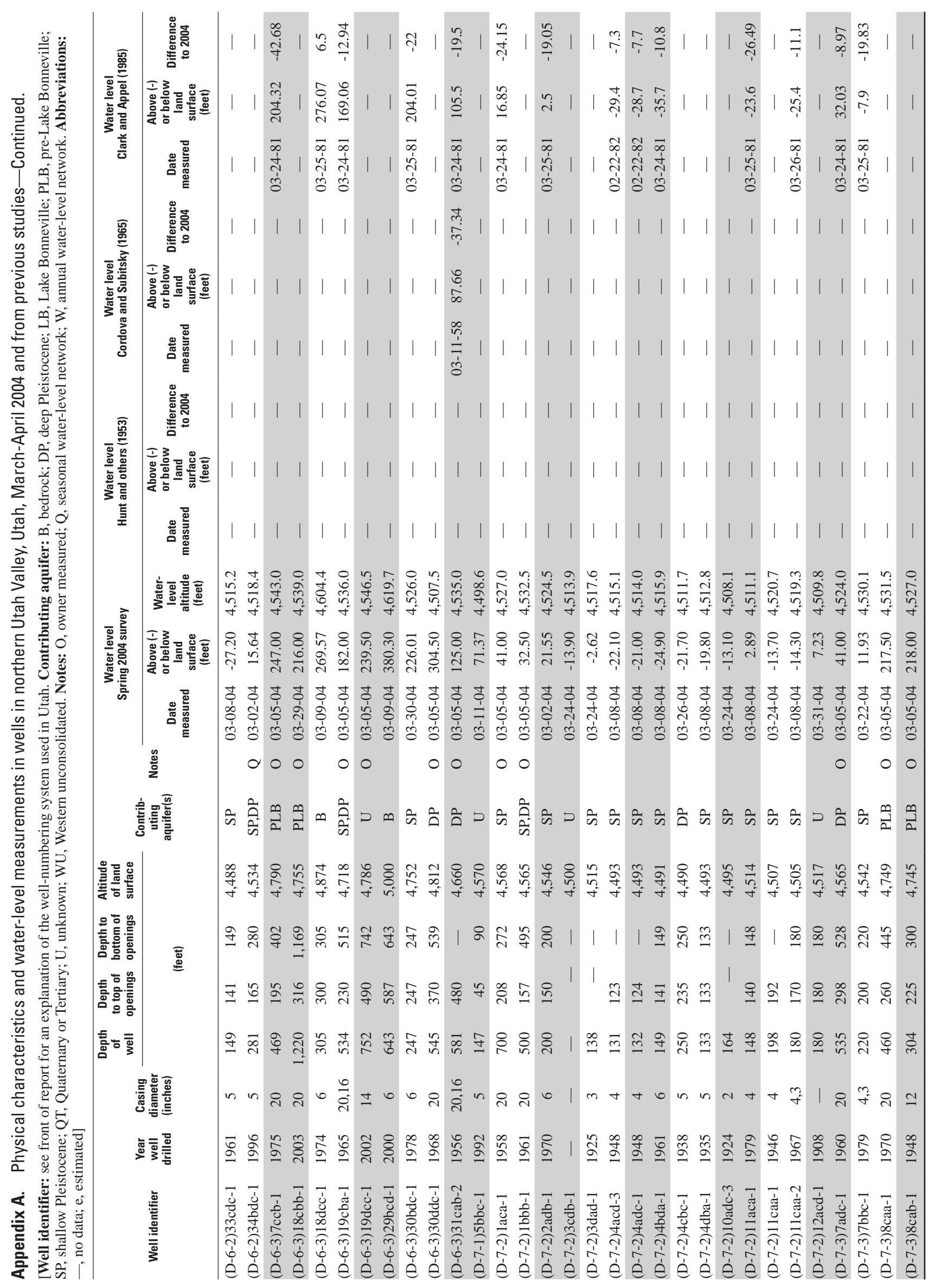


Appendix B. 


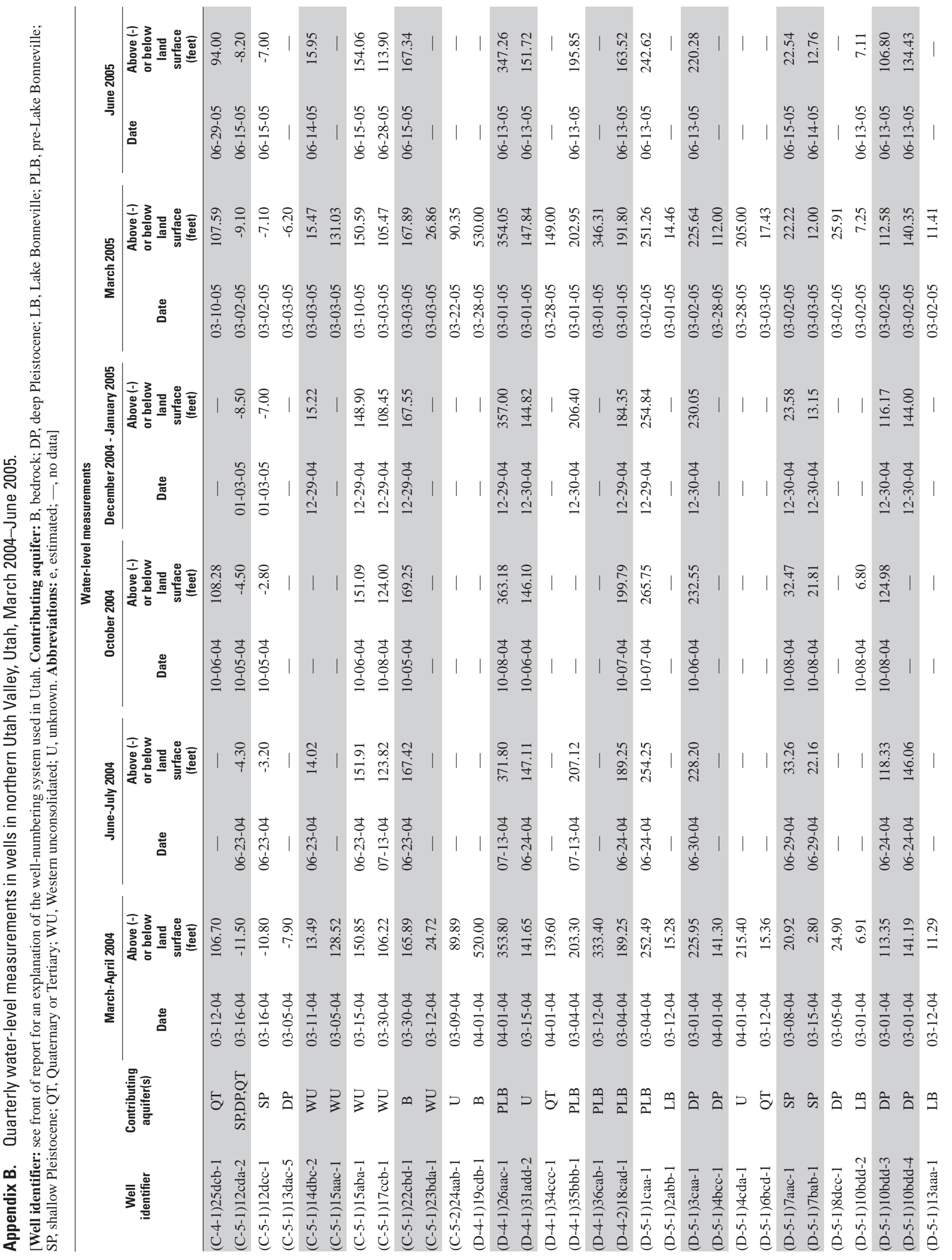




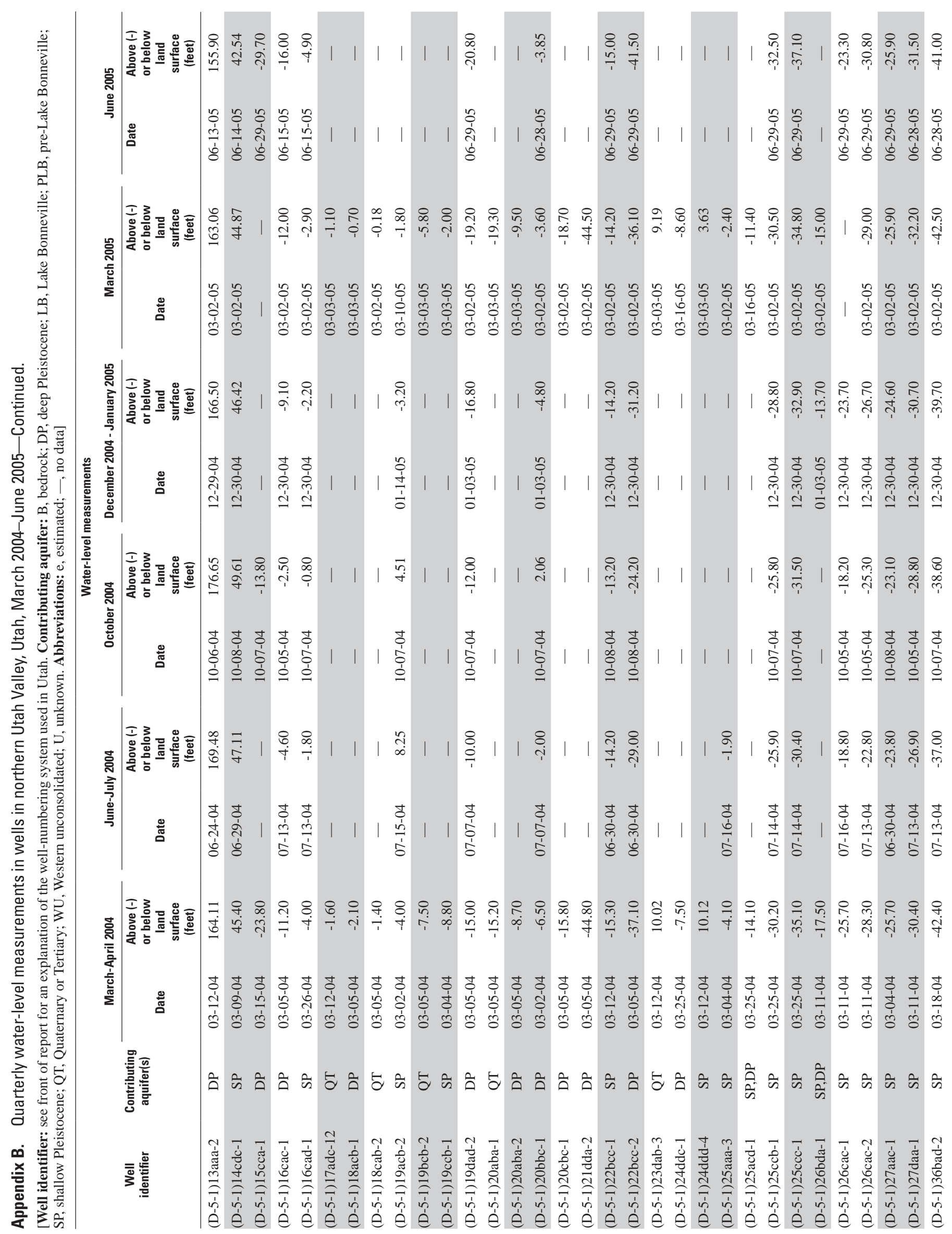




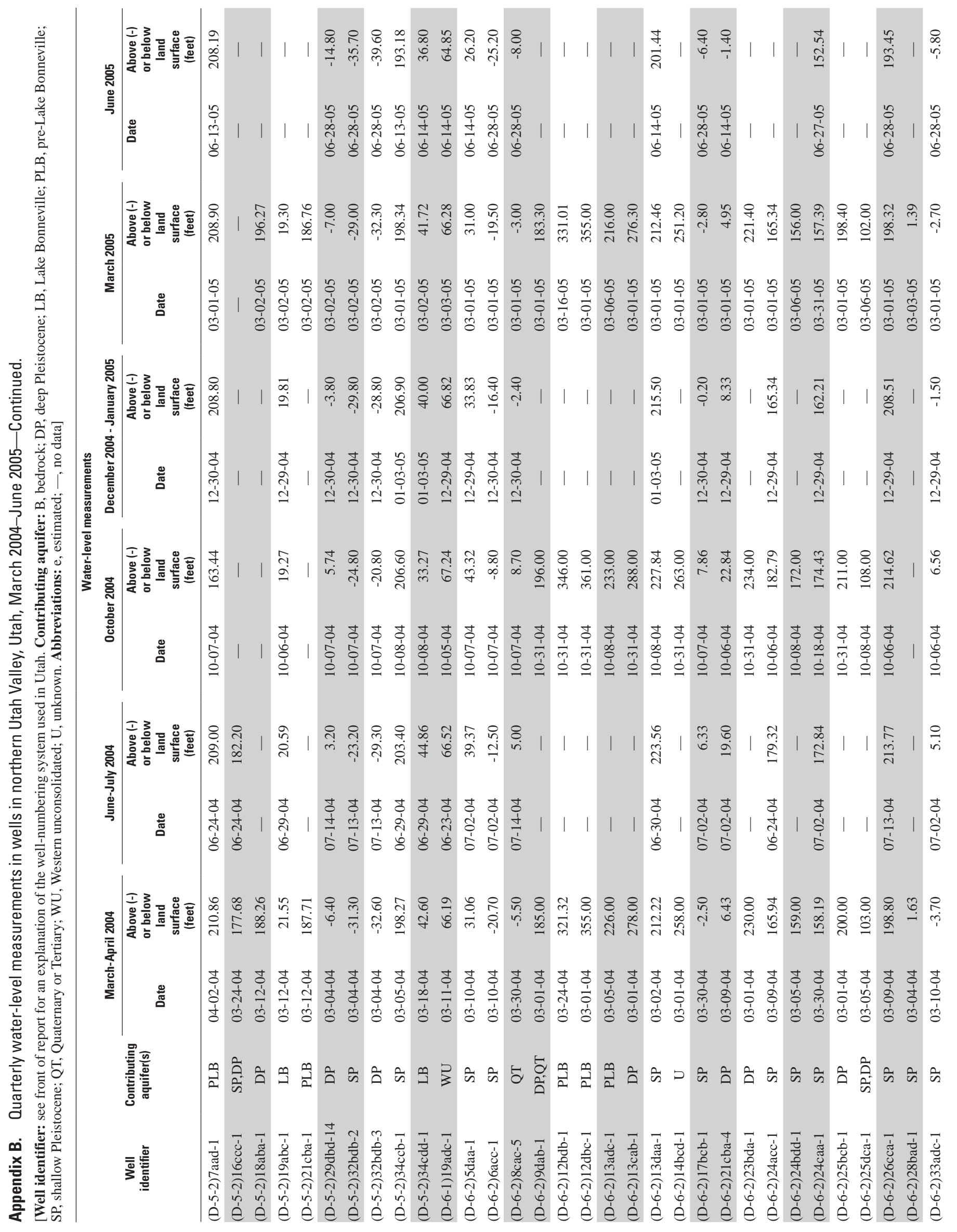




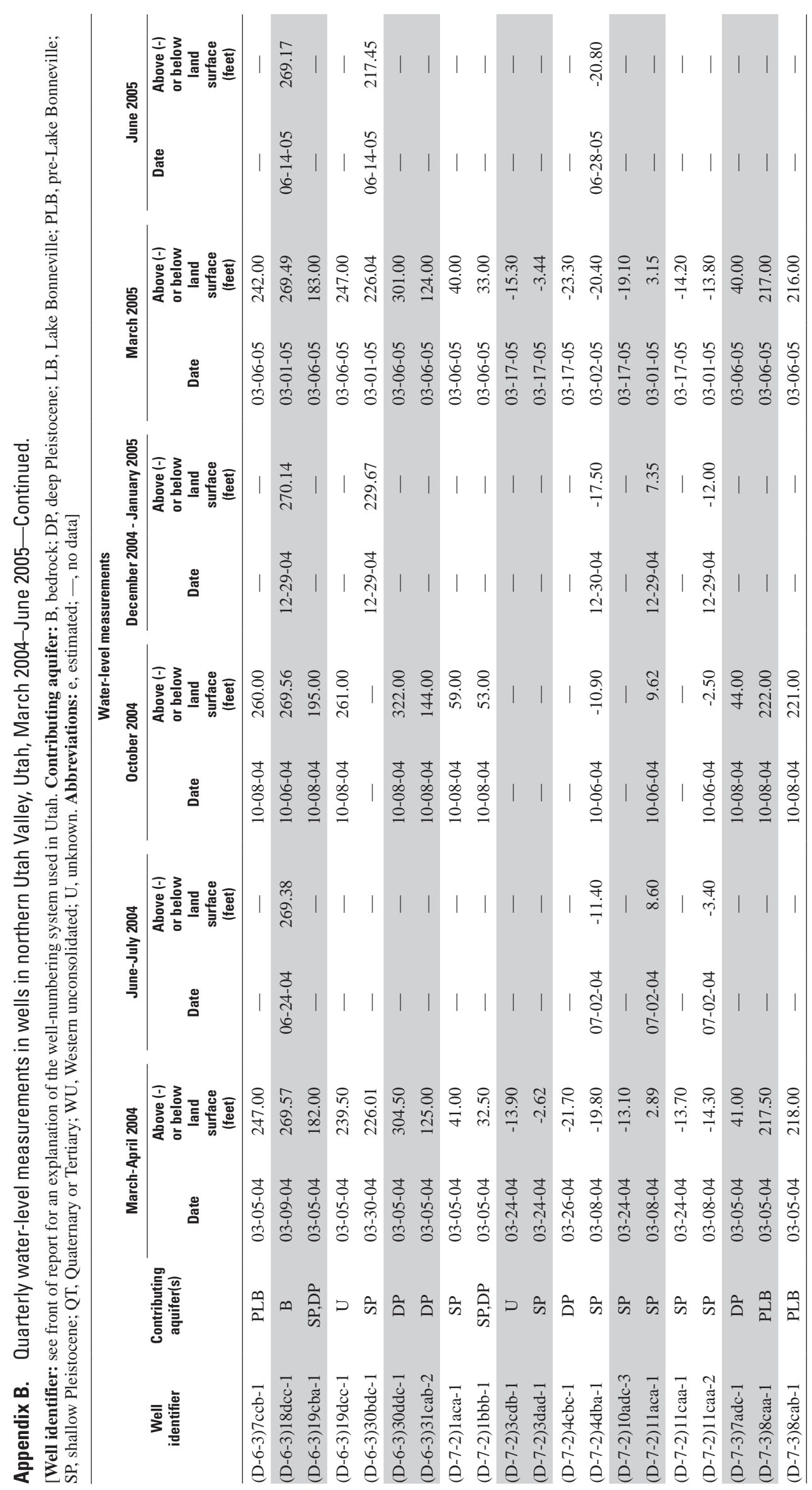


114 Hydrology of Northern Utah Valley, Utah County, Utah, 1975-2005 

